\title{
Costs and Cost Algorithms for Dry Cooling Tower Systems
}

by

P. A. Ard

C. H. Henager

D. R. Pratt

L. E. Wiles

September 1976

Prepared for the Energy Research and Development Administration under Contract EY-76-C-06-1830 
NOTICE

This report was prepared as an account of work sponsored by the United States Government. Neither the United States nor the Energy Research and Development Administration, nor any of their employees, nor any of their contractors, subcontractors, or their employees, makes any warranty, express or implied, or assumes any legal liability or responsibility for the accuracy. completeness or usefulness of any information, apparatus, product or process disclosed, or represents that its use would not infringe privately owned rights.

\author{
PACIFIC NORTHWEST LABORATORY \\ operated by \\ BATTELLE \\ for the \\ ENERGY RESEARCH AND DEVELOPMENT ADMINISTRATION \\ Under Contract EY-76-C-06-1830
}
Printed in the United States of America
Available from
National Technical information Service
U.S. Department of Commerce
5285 Port Royal Road
Springfield. Virginia 22151

-: Microfiche $\$ 3.00$

$\begin{array}{cc}\text {-Pages } & \text { NTIS } \\ \text { Selling Price } \\ 021-025 & \$ 4.50 \\ 026-050 & \$ 5.00 \\ 051-075 & \$ 5.50 \\ 076-100 & \$ 6.00 \\ 101-125 & \$ 6.50 \\ 126-150 & \$ 7.00 \\ 151-175 & \$ 7.75 \\ 176-200 & \$ 8.50 \\ 201-225 & \$ 8.75 \\ 226-250 & \$ 9.00 \\ 251-275 & \$ 10.00 \\ 276-300 & \$ 10.25\end{array}$




\title{
33679000626970
}

COSTS AND COST ALGORITHMS

FOR DRY COOLING TOWER SYSTEMS

\author{
by \\ P.A. Ard \\ C.H. Henager \\ D.R. Pratt \\ L.E. Wiles
}

September 1976

BATTELLE

Pacific Northwest Laboratories

Richland, Washington 99336 


\section{FORENORD}

The Dry Cooling Tower Development Program at Battelle, Pacific Northwest Laboratory was initiated with a program scope that included the following near-term and ultimate emphases.

Near-Term Objectives:

- Develop economic and performance models for cost optimization of total heat rejection systems using dry cooling.

- Analyses of, and dissemination of experience on, existing drycooled plant performance.

- Demonstrate certain features of existing technology equipment to provide confidence for specification by utilities.

Ultimate Objective:

- Promote water conservation through industry use of dry cooling by developing and demonstrating the reliability of lower-cost systems. The development of advanced dry/wet systems is also considered to be within this scope.

Over the past two years the following documents have been issued, reporting the results of the work toward these objectives.

Cost optimization of dry-cooled heat rejection systems:

A REVIEW AND ASSESSMENT OF ENGINEERING ECONOMIC STUDIES OF DRY COOLED ELECTRICAL GENERATING PLANTS. B. C. Fryer, BNWL-1976, March 1976.

HEAT TRANSFER AND PRESSURE DROP CHARACTERISTICS OF DRY TOWER EXTENDED SURFACES. PART I: HEAT TRANSFER AND PRESSURE DROP DATA. PFR Engineering Systems, Inc., PFR 7-100, March 1976.

HEAT TRANSFER AND PRESSURE DROP CHARACTERISTICS OF DRY TOWER EXTENDED SURFACES. PART II: DATA ANALYSIS AND CORRELATION. PFR Engineering Systems, Inc., PFR 7-102, June 1976. 
Analysis of performance of existing dry-cooled plants:

DRY COOLING TOWER PROGRAM: RESULTS OF INDUSTRIAL CONTACTS THROUGH AUGUST 1974. BNWL-1878, November 1, 1974.

A SURVEY OF MATERIALS AND CORROSION PERFORMANCE IN DRY COOLING APPLICATIONS. A. B. Johnson, Jr., D. R. Pratt and G. E. Zima, BNWL-1958, March 1976.

EUROPEAN DRY COOLING TOWER OPERATING EXPERIENCE.

J. G. DeSteese and K. Simhan, BNWL-1995, March 1976.

MATHEMATICAL AND EXPERIMENTAL INVESTIGATIONS ON DISPERSION AND RECIRCULATION OF PLUMES FROM DRY COOLING TOWERS AT WYODAK POWER PLANT IN WYOMING. Y. Onishi and D. S. Trent, BNWL-1982, February 1976.

Advanced dry (dry/wet) cooled systems:

PRELIMINARY EVALUATION OF WET/DRY COOLING CONCEPTS FOR POWER PLANTS. W. V. Loscutoff, BNWL-1969.

COMPATIBILITY OF AMMONIA WITH CANDIDATE DRY COOLING SYSTEM MATERIALS. D. R. Pratt, BNWL-1992, April 1976.

SCALE FORMATION IN DELUGED DRY COOLING SYSTEMS. D. R. Pratt, BNWL-2060, March 1976.

AMMONIA AS AN INTERMEDIATE HEAT EXCHANGE FLUID FOR DRY COOLED TOWERS. R. T. ATlemann, B. M. Johnson and G. C. Smith, BNWL-SA-5997, September 1976.

A group of reports (including this report) has recently been issued. This group serves the dual purpose of developing cost optimization models for dry cooling systems based on available technology and comparing the results of analyzing the costs of these systems with the projected cost of several advanced dry and dry/wet systems. Included in this group are:

AN ENGINEERING AND COST COMPARISON OF THREE DIFFERENT ALL-DRY COOLING SYSTEMS. B. C. Fryer, D. W. Faletti, Dan J. Braun, David J. Braun and L. E. Wiles, BNWL-2121, September 1976.

A STUDY OF THE COMPARATIVE COSTS OF FIVE WET/DRY COOLING TOWER CONCEPTS. F. R. Zaloudek, R. T. Allemann, D. W. Faletti, B. M. Johnson, H. L. Parry, G. C. Smith, R. D. Tokarz, and R. A. Walter, BNWL-2122, September 1976. 
DRY COOLING OF POWER GENERATING STATIONS A SUMMARY OF THE ECONOMIC EVALUATION OF SEVERAL ADVANCED CONCEPTS VIA A DESIGN OPTIMIZATION STUDY AND A CONCEPTUAL DESIGN AND COST ESTIMATE. B. M. Johnson, R. T. ATTemann, D. W. Faletti, B. C. Fryer and F. R. Zaloudek, BNWL-2120, September 1976.

COSTS AND COST ALGORITHMS FOR DRY COOLING TOWER SYSTEMS. P. A. Ard, C. H. Henager, D. R. Pratt and L. E. Wiles, BNWL-2123, September 1976.

A USER'S MANUAL FOR THE BNW-I OPTIMIZATION CODE FOR DRY-COOLED POWER PLANTS. David J. Braun, Dan J. Braun, Warren V. De Mier, D. W. Faletti and L. E. Wiles, BNWL-2180, January 1977. 


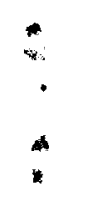




\section{ACKNOWLEDGMENTS}

This report contains an account of the work sponsored by the Division of Nuclear Research and Applications of ERDA under the Dry Cooling Tower Project at Battelle, Pacific Northwest Laboratory (PNL). The project was completed under the direction of I. He1ms, Project Officer; W. F. Savage, Manager of Advanced Concepts Evaluation Branch, ERDA Division of Nuclear Research and Applications; and B. M. Johnson, Manager of the Dry Cooling Tower Project at PNL.

The authors gratefully acknowledge Drs. Rudy T. Alleman, Benjamin M. Johnson, and Frank R. Zaloudek for their help in preparing and reviewing this document. We also wish to acknowledge the efforts of Drs. Brent C. Fryer and Duane $W$. Faletti for their advice and guidance throughout the development of this information; Tom $W$. Jeffs for the electrical system costs; and Andrea Currie for editing.

We wish to express appreciation to Vitro Engineering, Division of Automation Industries, Inc., for the circulation equipment costs.

Many manufacturers of components for cooling tower systems were contacted during the conduct of this study and provided essential cost information that was incorporated into the cost algorithms and estimates. We particularly thank the following individuals and their firms for providing fabrication information and products costs: Mike W. Larinoff of Hudson Products; John A. Murray of The Moore Company; B. W. Walters of the Tennessee Gas Transmission Company; Norman Rupp representing the Philadelphia Gear Company; James R. Houx of The Marley Cooling Tower Company; Dan Fuller, Westinghouse Electrical Corporation; John Bartz of the LINDE Division, Union Carbide Company; J. S. Nordin, Betz Environmental Engineers; T. M. LaRonge, Betz Laboratories, Inc.; E. T. Wanderer, Aluminum Company of America; L. J. Burvidas of M. W. Kellogg, Inc.; and Bill Richards of the International Institute of Ammonia Refrigeration. We acknowledge this vital contribution to the study, although any mistakes in interpretation and formulization of this information are the responsibility of PNL. 


\section{CONTENTS}

FOREWORD

ACKNOWLEDGMENTS

LIST OF FIGURES

LIST OF TABLES

1.0 INTRODUCTION

2.0 SUMMARY

3.0 HEAT TRANSFER BUNDLES . . . . . . . . . . . . . . . . . . 5

3.1 DESCRIPTION . . . . . . . . . . . . . . . . . . 5

3.2 HEAT TRANSFER ELEMENTS . • • • • • • • • • • . . . 6

3.2.1 Metal and Plastic Tubular Cooling

Surfaces and Finned Tube Liners . . . . . . 6

3.2.2 Extended Cooling Surfaces . . . . . . . . 11

3.2.3 Surface Coatings . . . . . . . . . . . 17

3.2.4 Bundle Element Spacers . . . . . . . . . 19

3.2.5 Tube End Preparation . . . . . . . . . . 20

3.2.6 Total Bundle Surface Costs . . . . . . . 21

3.3 BUNDLE HEADER COSTS FOR WATER AND AMMONIA SERVICE . . . . . 21

3.3.1 Tube Header Algorithms . . . . . . . . 21

3.3.2 Elastomer Sealed Tube Joint Algorithms . • • . . 26

3.4 BUNDLE FRAMES FOR HORIZONTAL AND VERTICAL TOWERS • • • . 27

3.4.l Bundle Frame Algorithms . . . . . . . . . 28

3.5 BUNDLE ASSEMBLY COSTS . . . . . . . . . . . . . . 29

3.5.1 Finned Tube Bundle Assembly . . . . . . . . 29

3.5.2 Plastic Tube Bundle Assembly . . . . . . . . 30

3.6 TOTAL HEAT TRANSFER BUNDLE COSTS . . . . . . . . . . . 31

3.7 LOUVERS AND HAIL SCREENS . . • • • • • . . . . 32

3.7 .1 Louvers . . . . . . . . . . . . . . 32

3.7 .2 Hail Screens . . . . . . . . . . . . . 33

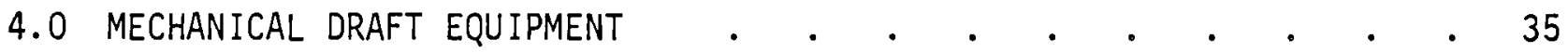

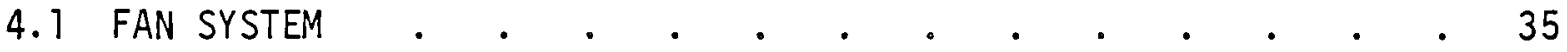

4.2 FAN COSTS . . . . . . . . . . . . . . . . . . . 35

4.3 FAN EQUIPMENT COSTS . . . . . . . . . . . . . . . . . . . 36 
4.4 FAN PLENUMS . . . . . . . . . . . . . . . . . . 37

4.4.1 Horizontal Heat Exchanger Plenums . . . . . 38

4.4.2 Vertical Heat Exchanger Plenums . . . . . . 39

4.5 FAN VELOCITY RECOVERY STACKS . . . . . . . . . 40

5.0 CIRCULATION SYSTEM . . . . . . . . . . . . . . . . . . 41

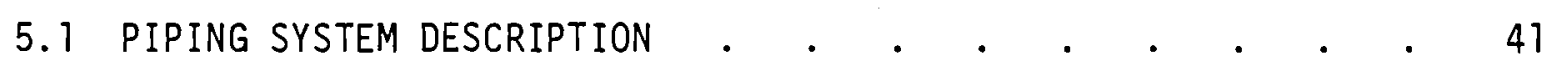

5.1 .1 Circular Towers . . . . . . . . . . . . 42

5.1 .2 Rectilinear Towers . . . . . . . . . 45

5.2 PIPING SYSTEM COST ANALYSIS . . . . . . . . . . . 47

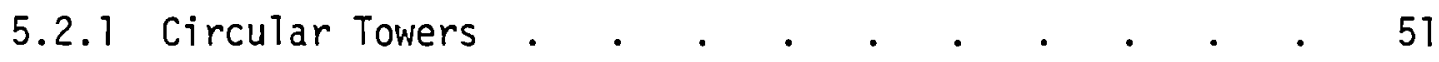

5.2.2 Rectilinear Towers . . . . . . . . . . 63

5.3 PIPING DESIGN AND COST ALGORITHM OUTLINE • . . . . $\quad 72$

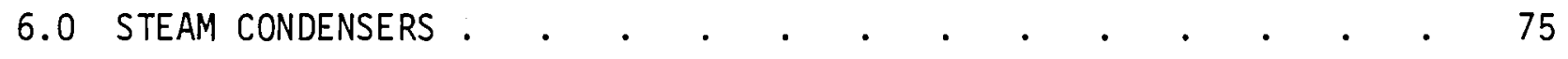

6.1 WATER-COOLED SURFACE CONDENSERS . . . . . . . . . . 75

6.1 .1 Condenser Tubing . . . . . . . . . . . . .

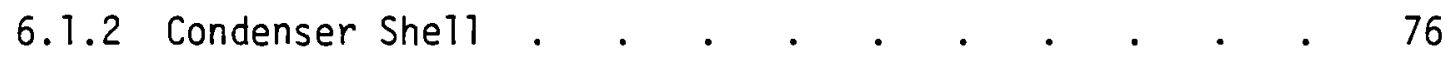

6.1 .3 Condenser Erection . . . . . . . . . . . 79

6.1 .4 Total Condenser Cost . . . . . . . . . . . . 80

6.2 CONDENSERS FOR AMMONIA COOLANT . . . . . . . . . . . 81

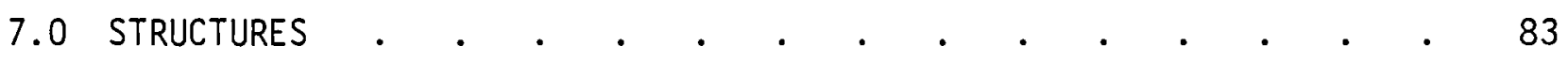

7.1 RECTANGULAR TOWER ARRANGEMENT COST ALGORITHMS . . ..$\quad 83$

7.1.1 Development of the Cost Algorithms . . . . . 84

7.2 CIRCULAR TOWER ARRANGEMENT COST ALGORITHMS • • • • . 90

7.2.1 Development of the Cost Algorithms . . . . . 90

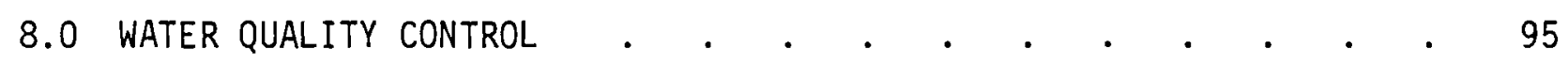

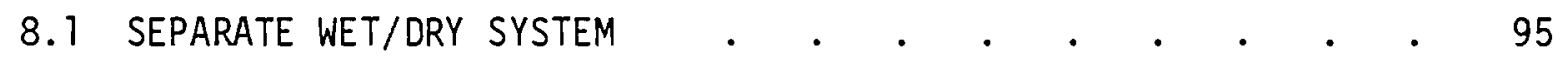

8.1.1 Dry Loop - Closed Recirculating System . . . . 96

8.1.2 Wet Loop - Conventional Evaporative Cooling . . . 100

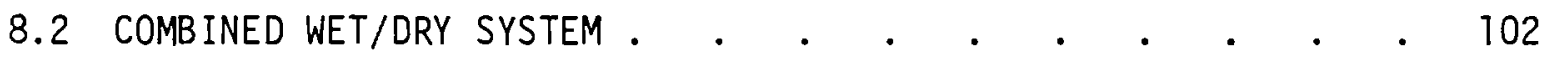

8.3 CLOSED RECIRCULATING DRY SYSTEM, DELUGED . . . . . 103

8.3.1 Dry Loop - Closed Recirculating System . . . . 103

8.3.2 Delugate Loop - Open Recirculating System . . . 103

8.3.3 Zero-Hardness Flush Water . . . . . . . 105 
8.4 SUMMARY OF WATER TREATMENT COSTS . . . . . . . . 105

9.0 COOLING TOWER ELECTRICAL SYSTEM . . . • . • • . . . . 107

9.1 FAN AND PUMP ELECTRICAL POWER SYSTEMS • • . . . . . 107

9.2 LIGHTING AND SERVICE OUTLETS . . . . . . . . . . 113

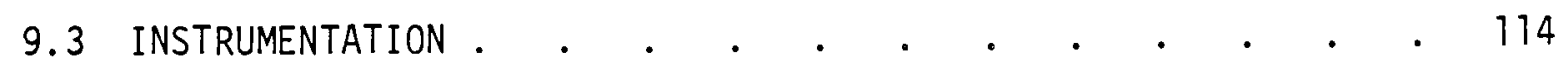

10.0 CONSTRUCTION COSTS . . . . . . . . . . . . . . 115

10.1 DIRECT CONSTRUCTION COSTS . . . . . . . . . . . . 115

10.2 INDIRECT COSTS . . . . . . . . . . . . . . . . . 116

10.3 ESCALATION AND CONTINGENCIES . . . . . . . . . 116

REFERENCES . . . . . . . . . . . . . . . . . . . 119

APPENDIX A - TUBING COST DATA • • . . • • • • • . . $A-1$

APPENDIX B - TUBING CORROSION DATA . . . . . . . . . . . . . B-1

APPENDIX C - TUBE FINNING COSTS . . . . . . . . . . . . . . $\quad$ C-1

APPENDIX D - MATERIAL AND NOZZLE COSTS . . . . . . . . . . . D-1

APPENDIX E - PLASTIC SPACER COSTS . . . . . . . . . E-1

APPENDIX F - HEADER WELDING COSTS . . . . . . . . . . . F-1

APPENDIX G - PLASTIC TUBE BUNDLE ASSEMBLY COSTS . . . . . . . . G-1

APPENDIX H - LOUVER AND SHUTTER COSTS . . . . . . . . . . . H-1

APPENDIX I - CIRCULATION SYSTEM COSTS . . . . . . . . . . . I-1

APPENDIX J - ELECTRICAL SYSTEM COSTS . . . . . . . . . . . J-1

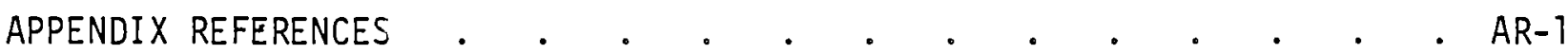


. $\leftarrow$ 


\section{LIST OF FIGURES}

3-1 Dry Cooling Tube Bundle Basic Components 5

3-2 Heat Exchanger Unit Typical Configurations 7

3-3 Round Tubing Section Geometry 8

3-4 Liner Costs for Wrap-On Finned Tubing with 30-Year

3-5 Liner Costs for Wrap-On Finned Tubing with 30-Year Corrosion Allowance for High Purity Condensate 11

3-6 Helical Wound Fins 12

3-7 Extruded Fins 13

3-8 Plate Fins 13

3-9 Shear-Raised Fins 14

3-10 Finning Unit Costs for 10 Fins Per Inch, Liner Not Included 18

3-11 Wrap-On Finned Tube Minimum Unit Surface Costs
for 10 Fins Per Inch

3-12 Typical Box Header Designs Used in Dry Cooling Tube Bundles 22

3-13 Header to Tube Joints 23

3-14 Dimensions Used in Header Cost Algorithm 24

4-1 Typical Fan Plenum Arrangements 38

5-1 Piping Subsystems for Circular Towers 43

5-2 Quadrant Headering for Water System 44

5-3 Piping Subsystems for Rectilinear Towers 46

5-4 Module Piping Showing One of Two Opposed Banks

5-5 Pump Station 51

5-6 Quadrant Piping Designs Studied 53

5-7 Tower Distribution Piping Designs Studied 56

5-8 Main Circulation Piping Design $\mathrm{Cl}$

5-9 Main Circulation Piping Design C2 60

5-10 Main Circulation Piping Design C3 60

5-11 Module Piping Designs Studied 65

5-12 Rectilinear Tower Main Circulation Piping Designs R1 and R2 68

5-13 Rectilinear Tower Main Circulation Piping Design R3 71 
7-1 Typical Flat Horizontal Dry Cooling Tower Structure Arrangement

7-2 Horizontal Dry Cooling Tower Structure Costs as a Function of Load

7-3 Typical Circular Dry Cooling Tower Structure Arrangement

8-1 Separate Wet/Dry Cooling System

8-2 Vacuum Deaerator

8-3 Treatment of Wet Tower Loop Water, Separate Wet/Dry System

8-4 Combined Wet/Dry Cooling System

101

8-5 Closed Recirculating Dry System, Deluged

102

8-6 Delugate Treatment

9-1 One Cooling Tower Electrical System Used for Costing

9-2 Fan and Pump Electrical and Control System Costs

9-3 Motor Electrical System Costs Using Cost Algorithms 


\section{LIST OF TABLES}

3-1 Standard Metal Tube Wall Thickness 9

3-2 Condenser and Plastic Tubing Costs and Densities 9

3-3 Length Cost Factors for Condenser Tubing 10

3-4 Cost Factors for Tube Finning 15

4-1 Algorithm Cost Data for Manual Controlled Pitch Fans
of Glass Reinforced Epoxy

5-1 Pump Station Cost Estimate 52

5-2 Quadrant Header Design Q1 Cost Estimate 54

5-3 Quadrant Header Design Q2 Cost Estimate 55

5-4 Tower Distribution Piping Design Tl Cost Estimate 57

5-5 Tower Distribution Piping Design T2 Cost Estimate 58

5-6 Main Circulation Piping Design Cl Cost Estimate 61

5-7 Main Circulation Piping Design C2 Cost Estimate 61

5-8 Main Circulation Piping Design C3 Cost Estimate 62

5-9 Capital Cost Comparison of Three Piping System Designs for Circular Towers 63

5-10 Module Piping Design M1 Cost Estimate 66

5-11 Module Piping Design M2 Cost Estimate 67

5-12 Main Circulation Piping Design R1 Cost Estimate 69

5-13 Main Circulation Piping Design R2 Cost Estimate 70

5-14 Main Circulation Piping Design R3 Cost Estimate 71

5-15 Capita1 Cost Comparison of Three Piping System Designs
for Rectilinear Towers

6-1 Basic Shell Cost Factors 78

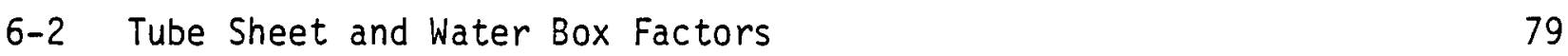

7-1 Structure Costs as a Function of Load 88

7-2 Accuracy of Cost Model Compared to Individual

7-3 Total Structural Steel Costs of Two Towers 94

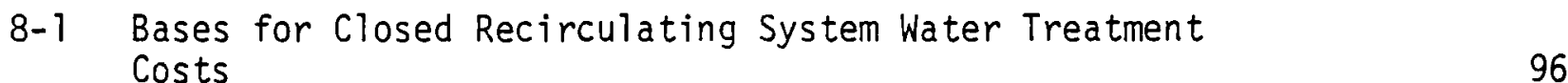

8-2 Water Treatment Capital Costs, Closed Recirculating System 
8-3 Water Treatment Operating Costs, Closed Recirculating Sys tem

8-4 Summary of Water Treatment Costs, Closed Recirculating System

8-5 Bases for Open Recirculating System Water Treatment Costs

8-6 Estimated Capital Costs of Water Treatment, Wet Tower Loop Water

8-7 Operating Cost for Open Recirculating System Water Treatment

8-8 Bases for Delugate Water Treatment Costs

8-9 Estimated Capital Costs of Delugate Treatment

8-10 Operating Cost for Delugate Treatment

8-11 Summary of Water Treatment Costs for A1ternative Cooling Tower Systems

9-1 Fan and Pump Electrical System Cost Summary and Unit Costs

10-1 Summary of Cooling System Direct Construction Cost Factors 
COSTS AND COST ALGORITHMS

FOR DRY COOLING TOWER SYSTEMS

\subsection{INTRODUCTION}

Battelle, Pacific Northwest Laboratory (PNL) is under contract to the Energy Research and Development Administration (ERDA) to assess and develop dry cooling as an option for the electrical power generation industry. Power plant steam is currently condensed by once-through cooling or by wet towers which evaporate water to the atmosphere. Environmental restrictions and decreasing availability of cooling water due to increasing water demands for agricultural, municipal, and industrial uses may make closed-cycle dry cooling attractive before the end of this century at some U.S. 1ocations. (2) Power plants using dry cooling have been shown to be more expensive to own and operate than conventional water-cooled or evaporation-cooled plants due in part to the higher capital costs of the dry cooling system. (3) These costs could be reduced for application to large power plants through optimization of presently available dry cooling systems and the use of advanced system concepts. The optimization study requires the use of component manufacturing cost models which aid in evaluating system design and material alternatives. This report discusses the models that were applied to both present state-of-the-art systems and advanced concepts in a costing analysis computer model prepared by PNL. (4)

The objective of this task was to determine costs and cost algorithms of components to be used in the all-dry systems, as well as those applicable to the combined wet/dry systems.

The initial work consisted of determining presently available dry cooling system component designs, construction materials, manufacturing methods and component costs. This was accomplished through a review of available literature, and contacts with cooling system component manufacturers. Using 
the information obtained, cost models were developed for the dry cooling cost sensitivity studies. Several models have factors covering alternative designs, materials, and methods of manufacture. Special emphasis was placed on the extended surface alternatives because of their expense and uniqueness to the dry cooling system. 


\subsection{SUMMARY}

Costs were obtained and cost models prepared for the major dry cooling components beyond the turbine exhaust flange. Components included the condenser, circulation system, tower structure, and heat transfer units (tube bundles), as well as forced draft, water quality control, and electrical sys tems. The cost data and models were developed for the indirect cooling system using mechanical draft and surface condensers. The models described in this report are capable of costing both water-and ammonia-cooled systems.

The heat transfer bundle models (Section 3 ) were developed to evaluate four general classifications of heat transfer surfaces: bare tube, wrap-on fin, extruded fin and plate fin. Costs are available for several different materials including plastic tubes. The mechanical draft system (Section 4) was costed by individual components (fan assemblies, motors, speed reducers, etc.) based on the fan size and the horsepower required. This information originated from the PNL fan selection computer program.

The circulation system (Section 5) was also costed by individual component for water to $125 \mathrm{psig}$ and $150^{\circ} \mathrm{F}$ and ammonia to $450 \mathrm{psi}$ and $150^{\circ} \mathrm{F}$. The circulation system costs, developed by Vitro Engineering, included both material and installation costs. The condenser costs and models (Section 6) were derived from the latest Westinghouse surface condenser price 1 ist. Costing was based on condenser tubing size and type, tubing length, and total surface area. Price variations are also included to cover modifications for the ammonia system.

Costs of rectangular and circular tower configurations are covered in Section 7 . The costs include site preparation, foundations, and the structure. Both tower types are included on the bases of total frontal areas of the heat transfer surfaces and unit weights. The circular tower model also takes into account the bundle length which dictates the tower height.

The water quality control costs (Section 8) include capital costs and annual operating costs for a separate wet/dry system, a combined wet/dry system, and a dry deluge system. Costs include demineralization, deaeration, 
corrosion inhibition, side stream treatment, scale inhibition, and biofouling control, depending on the system being considered.

The cooling tower electrical power system costs (Section 9) include the major electrical system components required for plants up to 1000 MWe. The cost algorithms are based on the size, number, and voltage of the fan and circulation pump motors. Included in the system cost is the cost of the plant electrical system--transformers, main switch gear, etc.--used in supplying all the plant equipment prorated in proportion to the expected power absorbed by the tower electrical system.

Costs used in the analyses were current or updated to the first half of 1976. The costs reflect southwestern U.S. labor rates and are believed accurate within +30 percent to -15 percent. However, there is no such thing as a correct cost for any construction. Material costs will vary considerably among suppliers at any given time and, as evidenced from their bid spreads, contractors performing the same work at the same location will experience greatly different costs. Many costs were estimated by persons knowledgeable in a specific field or area and were not the result of firm bids. Several cost relations used were developed from plots of costs against some controlling parameter (weight, horsepower, etc.). This was necessary to determine trends and the degree of the trends for the dry cooling tower economic evaluation. As these cost relations are a best fit curve, some point-to-point cost accuracy was lost. 


\subsection{HEAT TRANSFER BUNDLES}

The analysis of the heat transfer bundle models is discussed in this section.

\subsection{DESCRIPTION}

Heat transfer bundles (usually called tube bundles) are generally rectangular assemblies, designed to be shipped and mounted as self-contained units. A bundle consists basically of the heat transfer surfaces (including spacers), headers, bundle frame (side channels), and cross supports. The bundle requires spacers between individual surface elements (tubes) to maintain the desired spacing and prevent meshing or deformation of fins. Supports placed across the unit at the spacer locations hold the surface elements in position and prevent the long elements from sagging when in the horizontal position. Figure 3-1 shows the basic bundle components.

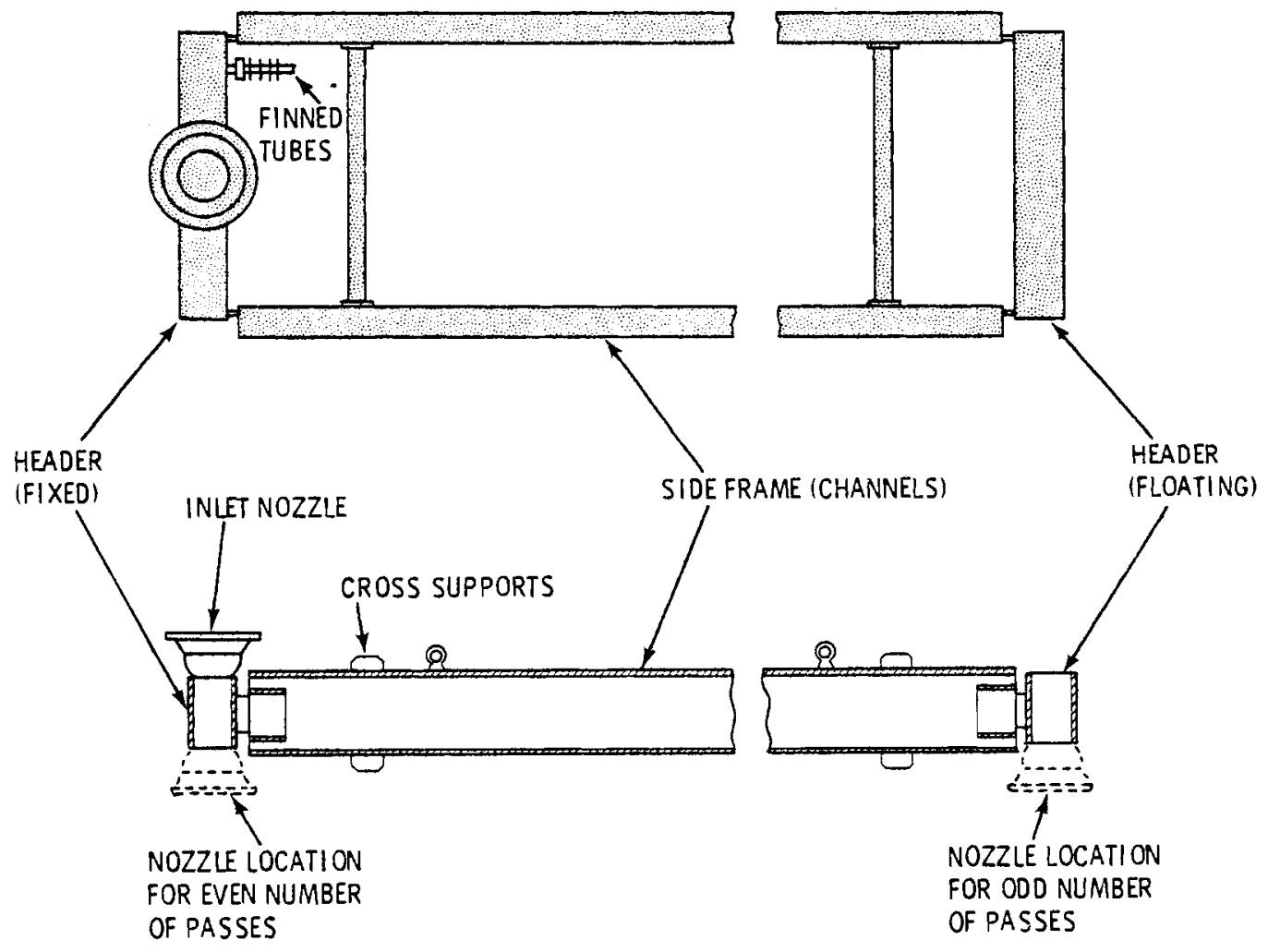

FIGURE 3-1. Dry Cooling Tube Bundle Basic Components 
The bundles may be mounted horizontally, vertically, or in an A-frame configuration, as shown in Figure 3-2. The horizontal configuration may be positioned flat or the ends elevated to an open " $V$ " to aid unit draining during shutdown, particularly in freezing weather. In the A-frame configuration, the bundles slope upward and meet at the center top with forced draft fans below. The vertical units are mounted around a circular (or rectangular) tower with the fans in the top of the tower.

\subsection{HEAT TRANSFER ELEMENTS}

Several types of heat transfer elements are used, ranging from smooth round tubes to various forms of extended surfaces, such as helical fins, longitudinal fins, spines, studs, etc. Smooth tubular cooling surfaces of both metal and plastic and metal finned tubes will be considered here.

\subsubsection{Metal and Plastic Tubular Cooling Surfaces and Finned Tube Liners}

The smooth surfaces proposed for air coolers are usually round tubing, although elliptical shapes elongated in the direction of air flow could be used with little increase in bundle costs if a higher surface-to-internal volume ratio is desired.

Costs for both tubular surfaces and liners for extended surfaces can be approximated by the following linear function of cost versus weight for each material considered.

where

$$
\text { Tubing costs }\left(C_{l}\right)=\left(C_{l m} w_{l}+C_{l}\right) \text { FM }
$$

$$
\begin{aligned}
& C_{l m}=\text { tubing material costs }(\$ / 1 \mathrm{~b}) \\
& C_{\ell}=\text { tubing added unit costs }(\$) \\
& w_{l}=\text { weight/foot }=12 \pi \rho_{l}\left(D_{l}-t_{w}\right) t_{w}, \text { as shown in Figure } 3-3, \\
& \text { where } \\
& \rho_{\ell}=\text { material density }\left(1 \mathrm{~b} / \mathrm{in}^{3} .^{3}\right. \\
& D_{l}=\text { tubing } 00 \text { (in.) } \\
& \left.t_{w}=\text { tubing wall thickness (in.) (See Table } 3-1\right) .
\end{aligned}
$$




\section{,}

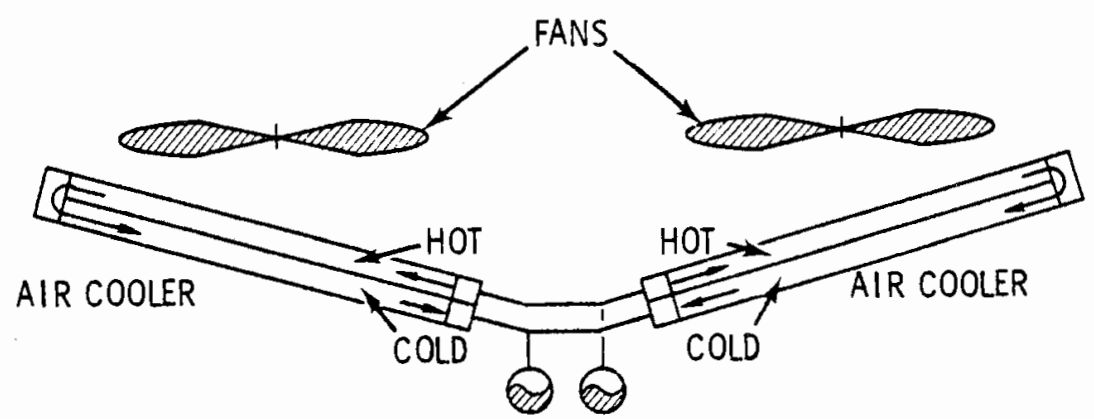

OPEN-VEE POSITION

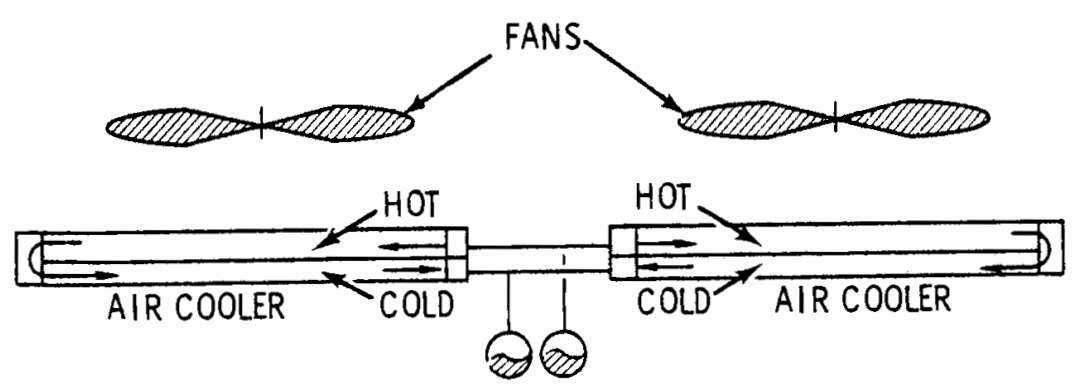

FLAT POSITION

HORIZONTAL CONFIGURATIONS

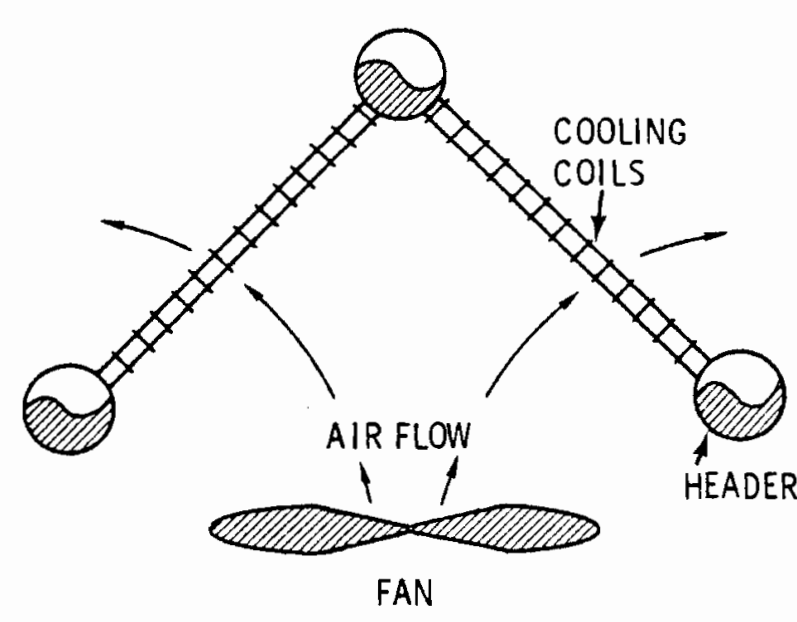

A-FRAME CONFIGURATION

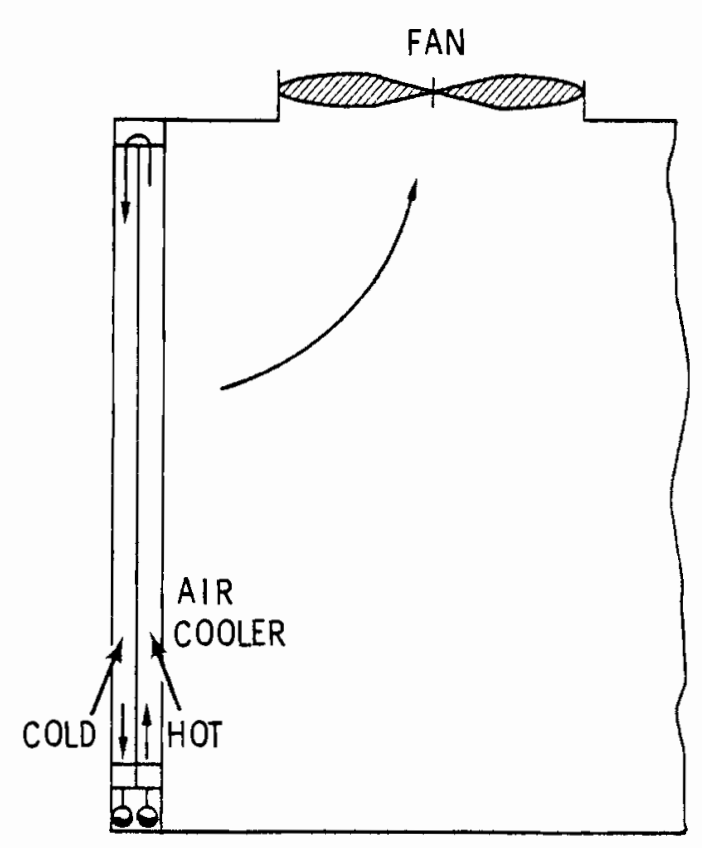

VERTICAL CONFIGURATION

FIGURE 3-2. Heat Exchanger Unit Typical Configurations 


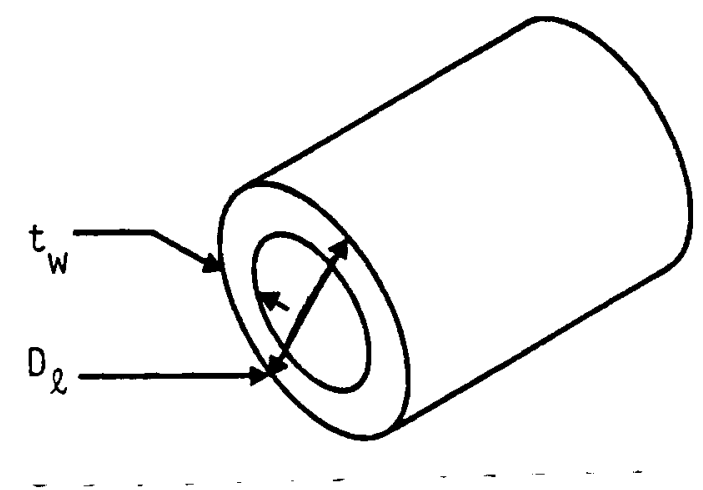

FIGURE 3-3. Round Tubing Section Geometry

$$
\begin{aligned}
& \text { Values for } C_{l m}, C_{\ell}^{\prime} \text {, and } \rho_{\ell} \text { are given in Table } 3-2 . \\
& F=\text { tubing length factor (see Table } 3-3 \text { ) } \\
& M=\text { tubing procuring, shipping and handling cost factor: } \\
& \quad 1.10 \text { (estimated). }
\end{aligned}
$$

Figures 3-4 and 3-5 plot the costs developed for six types of condenser tubing when used with wrap-on fins. A 30-year corrosion allowance was added to the tubing wall thickness required for either the service pressure or the finning operation, whichever was greater. For the low pressures and temperatures $\left(<200 \mathrm{psi}\right.$ and $\left.<200^{\circ} \mathrm{F}\right)$, the wall thicknesses are generally dictated by the finning operation unless a significant corrosion allowance is required. The corrosion allowances for the five tubing materials are presented in Appendix $B$ for normal steam condensate ${ }^{(5-7)}\left(0.5 \mu \mathrm{mho} / \mathrm{cm}, 0_{2}<\right.$ $50 \mathrm{ppb}, \mathrm{pH} 8.5)$, and high-purity oxygen inhibited condensate $(5,7,8) 2$ $\left(0.1 \mu \mathrm{mho} / \mathrm{cm}, \mathrm{O}_{2} 150\right.$ to $\left.200 \mathrm{ppb}, \mathrm{pH} 7.0\right)$, and inhibitor controlled condensate. $(9-12)$ The high-purity oxygen inhibited water is becoming a standard boiler feed water in Europe and is used in this country in boiling water reactors. (13) Tubing wall thicknesses for both wrap-on and extruded fin tubes when using either normal or high purity water are given in Appendix B. 
TABLE 3-1. Standard Metal Tube Wall Thickness $\left(t_{w}\right)$

$\begin{array}{ccc}\frac{B W G}{22} & & \frac{t_{W}(\text { in.) }}{0.028} \\ 20 & & 0.035 \\ 19 & & 0.042 \\ 18 & & 0.049 \\ 17 & 0.058 \\ 16 & 0.065 \\ 15 & 0.072 \\ -- & 0.078 \\ 14 & 0.083 \\ 13 & 0.095 \\ 12 & 0.109 \\ 11 & 0.120 \\ 10 & 0.134\end{array}$

TABLE 3-2. Condenser and Plastic Tubing Costs and Densities(a) ASTM

\begin{tabular}{|c|c|c|c|c|}
\hline Material & $\begin{array}{c}\text { ASTM } \\
\text { Specification }\end{array}$ & $\underline{C}_{l}^{\prime}-(\$ / \mathrm{ft})$ & $\underline{c}_{\ell m-1}(\$ / 1 \mathrm{~b})$ & $\underline{\rho}_{\ell}\left(1 b / i n .^{3}\right)$ \\
\hline Admiralty (443) & $B-111$ & 0 & 1.30 & 0.308 \\
\hline $\mathrm{Cu}-10 \mathrm{Ni}(706)$ & $B-111$ & 0 & 1.52 & 0.323 \\
\hline $\mathrm{Cu}-30 \mathrm{Ni}$ (715) & $B-111$ & 0 & 1.83 & 0.323 \\
\hline 6061-T6 A1 & $B-234$ & 0.08 & 1.40 & 0.0975 \\
\hline $3003-\mathrm{H} 14$ Al & $B-234$ & 0.04 & 1.36 & 0.0975 \\
\hline 3003-0 Al & $B-210$ & 0.05 & 1.04 & 0.0975 \\
\hline Steel (seamless) & $A-179$ & 0.38 & 0.44 & 0.284 \\
\hline Steel (welded) & $A-214$ & 0.12 & 0.32 & 0.284 \\
\hline 304 S/S (welded) & $A-249$ & 0.20 & 1.63 & 0.29 \\
\hline Titanium Grade 1 & $B-338$ & 0.15 & 7.60 & 0.163 \\
\hline Titanium Grade 2 & $B-338$ & 0.10 & 7.00 & 0.163 \\
\hline Polyethylene Plastic & & 0 & 0.720 & 0.035 \\
\hline Polypropylene Plastic & & 0.002 & 0.775 & 0.033 \\
\hline
\end{tabular}

(a) Refer to Appendix A. 
TABLE 3-3. Length Cost Factors for Condenser Tubing (a)

\begin{tabular}{|c|c|c|c|c|}
\hline Length Range $(\mathrm{ft})$ & $\begin{array}{c}\text { Copper } \\
\text { Alloys }(\$ / f t)(b)\end{array}$ & $\begin{array}{c}\text { Stainless } \\
\text { Steel } \\
\text { (Welded) } \\
\end{array}$ & $\begin{array}{l}\text { Carbon Steel } \\
\text { (Welded and } \\
\text { Seamless) }\end{array}$ & $\begin{array}{l}\text { Aluminum } \\
\text { Alloys }\end{array}$ \\
\hline $20-30$ & 0 & 1.00 & 1.00 & 1.00 \\
\hline $30-40$ & 0 & 1.00 & 1.09 & 1.06 \\
\hline $40-50$ & 0 & 1.04 & 1.13 & 1.10 \\
\hline $50-60$ & +0.07 & 1.08 & 1.17 & 1.14 \\
\hline $60-70$ & +0.08 & 1.12 & 1.21 & 1.18 \\
\hline $70-80$ & +0.09 & 1.14 & 1.25 & 1.22 \\
\hline
\end{tabular}

(a) These are average factors for estimating and will vary among manufacturers.

(b) The factor $(F)$ for copper alloys is 1.00 and the values in this column are to be added instead.

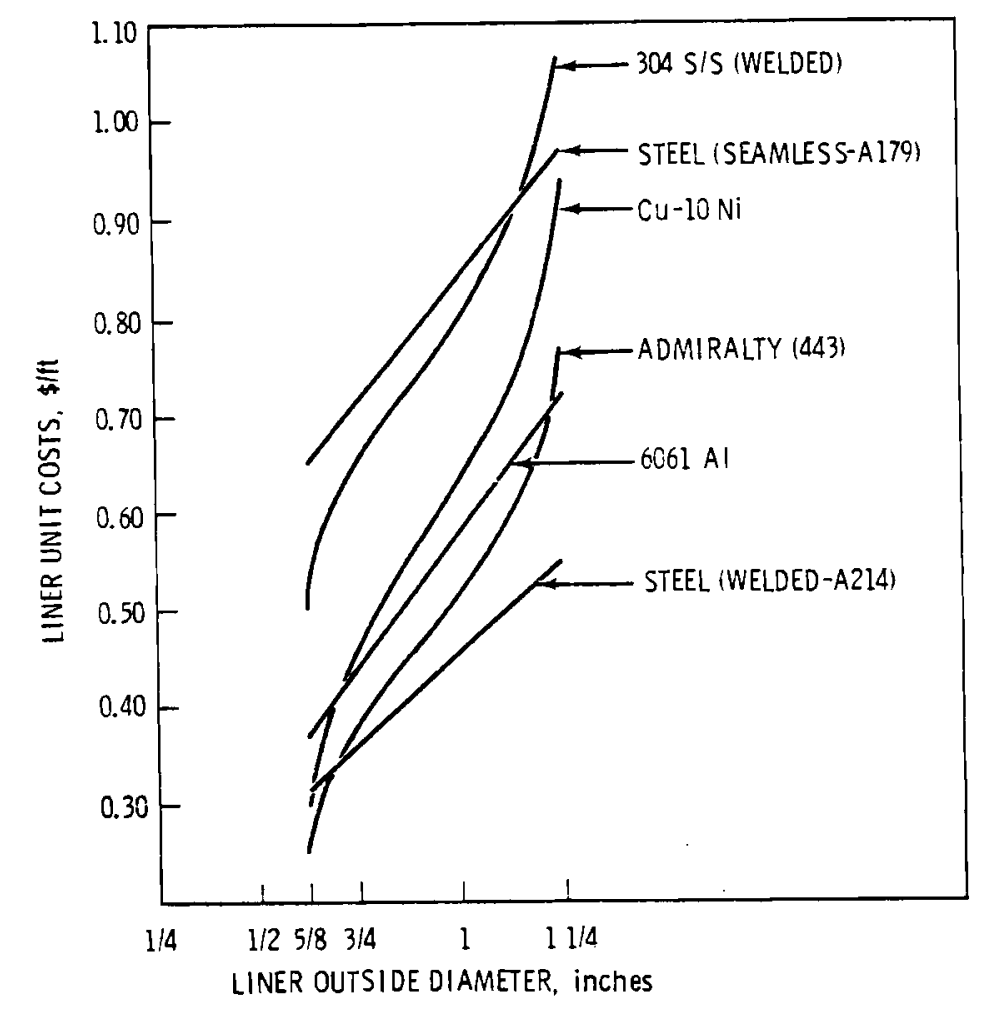

FIGURE 3-4. Liner Costs for Wrap-On Finned Tubing with 30-Year Corrosion Allowance for Normal Boiler Condensate 


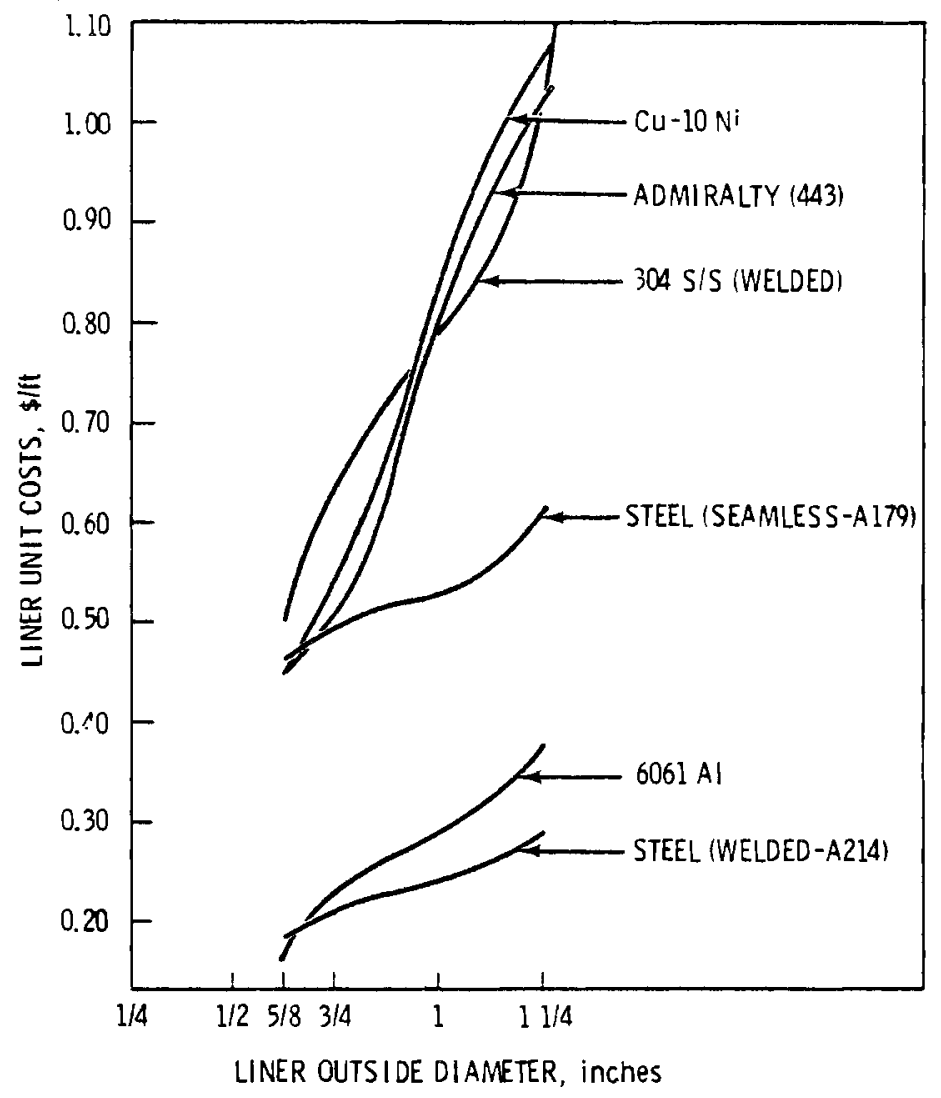

FIGURE 3-5. Liner Costs for Wrap-On Finned Tubing with 30-Year Corrosion Allowance for High Purity Condensate

Proper material and water treatment rather than thicker tube walls will improve the reliability of the heat exchanger liners. Tube failure generally occurs by highly selective attack and added wall thickness will only forestall the failure for a short period, while proper alloy and water quality will prevent it.

\subsubsection{Extended Cooling Surfaces}

The extended surfaces used most commonly throughout the large air cooler industry are metal finned tubing. Most finned surfaces can be classified into four general types for cost analysis based on the method of finning: 1) helical wrap-on fins, 2) extruded fins, 3) plate fins, and 4) shearraised fins.

The helical wound or wrap-on finned tubing is produced by tensionwinding a thin metal strip (usually aluminum or steel) edgewise around the 
liner tube as shown in Figure 3-6. As the strip is wrapped around the tube, it is stretched progressively thinner toward the fin OD producing a fin with a gradual taper. Four helical wound fin types--straight, footed, doublefooted (overlapped), and embedded--are included in Figure 3-6.

The extruded fin is produced by rotating a tubular fin stock through high pressure rolls, extruding a portion of the tube material into helical

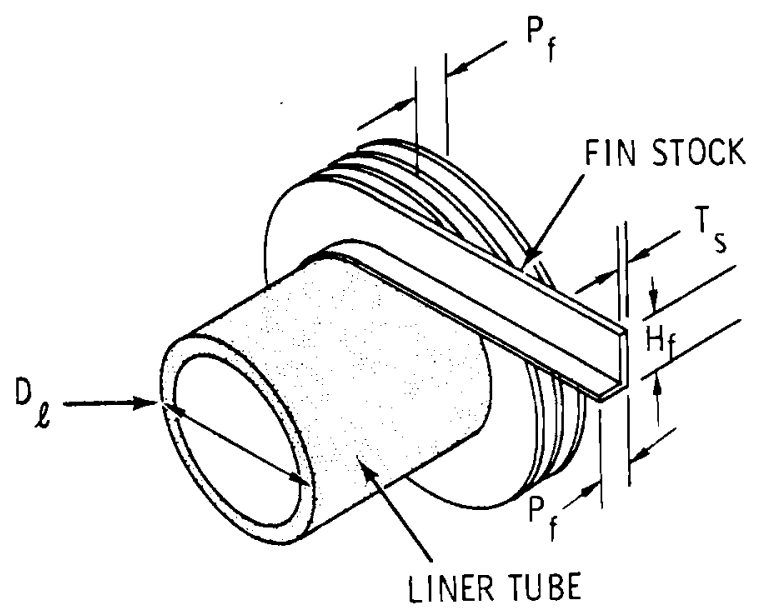

HELICAL WINDING STEP

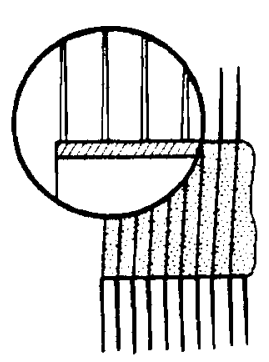

STRAIGHT FIN

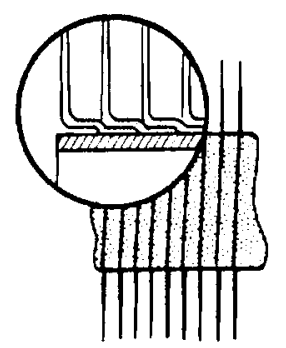

DOUBLE-FOOTED FIN
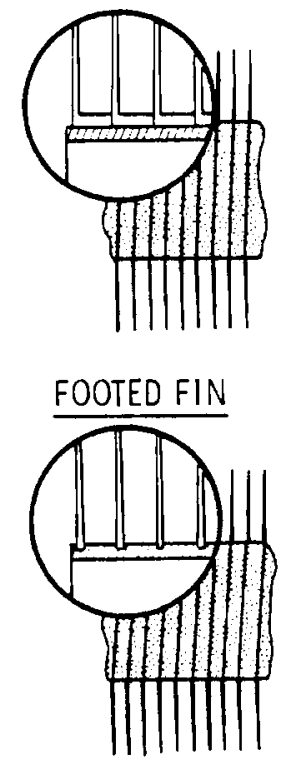

EMBEDDED FIN

FIGURE $3-6$. Helical Wound Fins 
fins. The extruded fin may be an integral finned tube (no liner tube) or a bimetal finned assembly as shown in Figure 3-7. The tubular fin stock is placed over the liner tube and the combination passed through the finning machine to produce the bimetal finned tube. The result is a finned tube compressed firmly onto the liner tube with no crevice or crack through the fin material to the liner tube. This type of fin, together with the helical wrap-on fins, is used extensively by U.S. industries.

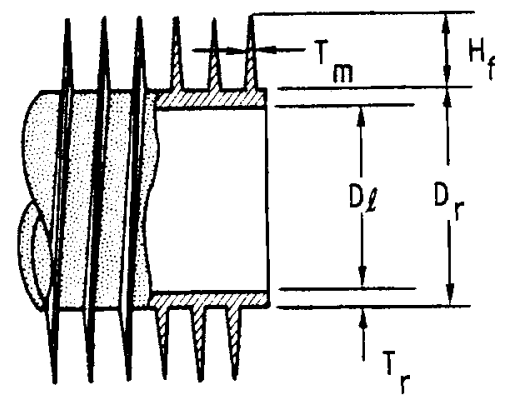

INTEGRAL. FIN

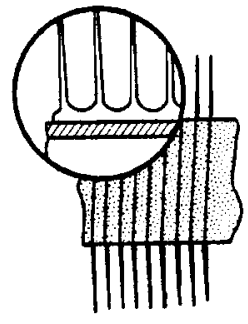

BIMETAL FIN

FIGURE 3-7. Extruded Fins

The plate fins are constructed by punching holes in the plates through which the liner tubes are inserted. To maintain fin spacing and to increase contact surface between the plate and tubes, spacing collars are used. These collars are either separate spacers or punched as an integral part of the plate. The two plate fin types are shown in Figure 3-8. After assembly, the liner tube is generally expanded to improve contact between the plate (and collars) and the liner tube.

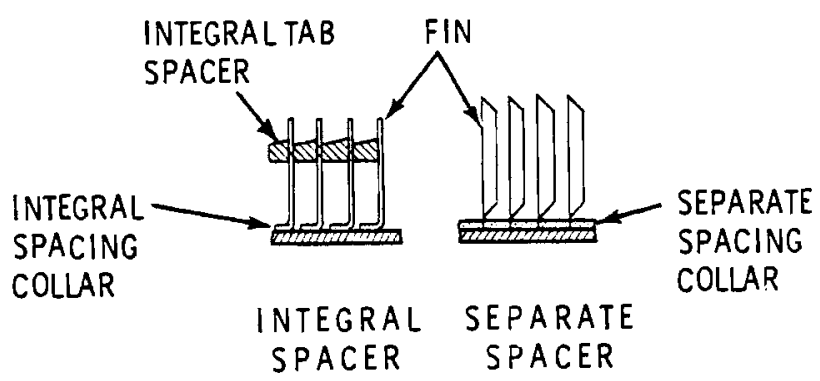

FIGURE $3-8$. Plate Fins 
The shear-raised fin surface (Figure 3-9) is produced by shearing the fin from the outer portion of the tube or channel wall, producing a fin integral with the tube or channel. This type of cooling surface is a fairly recent development and has not been adopted for use in large dry-cooled plants. This surface will be cost modeled at a later date to evaluate its economical potential for dry-cooled plant use.

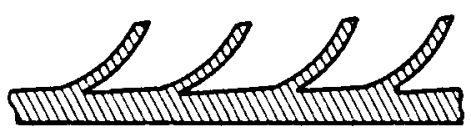

FIGURE 3-9. Shear-Raised Fins

The helical wrap-on and plate fins are occasionally bonded to the liner tube to improve heat transfer and/or eliminate the crevice for corrosion reasons. The bonding may be accomplished by resistance welding, soldering, or brazing. Galvanizing to protect steel fins from corrosion will also bond the fin to the liner tube.

Most finning costs can be approximated by using a fin weight/cost relationship. The following relationships include fin-to-liner bonding costs, although these costs were not developed.

$$
\text { Finning cost }\left(C_{f}\right)=C_{f m} w_{x f}+C_{f b} A_{b}+C_{f}^{\prime}=\$ / f t
$$

where

$$
\begin{aligned}
& \left.\begin{array}{l}
c_{f m}=\text { fin material costs }(\$ / 1 b) \\
C_{f}^{-}=\text {finning fixed costs }(\$ / f t)
\end{array}\right\} \text { see Table 3-4 } \\
& c_{f b}=\text { fin bonding costs }\left(\$ / f t^{2}\right. \text { of bond) } \\
& A_{b}=\text { bond area per } \mathrm{ft} \text { of tubing }\left(\mathrm{ft}^{2} / \mathrm{ft}\right) \\
& =12 \pi D_{l} P_{f}^{T} s \\
& W_{x f}=\text { fin material } w t(1 b / f t) \text { for fin types } \\
& \text { under consideration }
\end{aligned}
$$


TABLE 3-4. Cost Factors for Tube Finning $(a)$

\begin{tabular}{|c|c|c|c|}
\hline Fin Type & ${ }_{A T}{ }^{C}{ }_{f m}$ & $\frac{(1 \mathrm{~b})}{\text { Stee } 1}$ & $C_{f}^{-}(\$ / f t)$ \\
\hline \multicolumn{4}{|l|}{ Wrap-on: } \\
\hline Straight fin & $0.90^{(b)}$ & $0.24^{(e)}$ & 0.15 \\
\hline Single-footed & $0.90^{(b)}$ & & 0.15 \\
\hline Double-footed & $0.90^{(b)}$ & & 0.15 \\
\hline Embedded & $0.90^{(b)}$ & $0.24^{(e)}$ & 0.20 \\
\hline Extruded & $1.46^{(c)}$ & & $(-0.11)$ \\
\hline Plate & $0.95^{(d)}$ & & 0.20 \\
\hline
\end{tabular}

(a) Limited to liner sizes $5 / 8$ in. to $11 / 2$ in. $O D$.

(b) 1100 grade aluminum strip.

(c) 3003 aluminum includes finning.

(d) 1100 grade aluminum sheet includes fin sizing and shaping.

(e) 1010 steel strip.

Technical and pricing information on tube finning is contained in Appendix C.

Helical Wrap-On Fin Cost Algorithms

Fin material weights for tension-wrapped fins can be approximated by determining the stock weight (see Figure 3-6) forming the fin. The following weight relations were developed for helical wrap-on fins:

- straight fin

$$
W_{s f}=12 P_{f}\left(\pi D_{l} H_{F} T_{s}\right) p_{f}
$$

- footed fin

$$
W_{f f}=W_{s f}+\frac{W_{s f}}{H_{f}}\left(\frac{1}{P_{f}}-T_{s}\right)
$$

- double-footed fin

$$
W_{d f}=W_{s f}+\frac{W_{s f}}{H_{f}}\left(\frac{2}{P_{f}}-T_{s}\right)
$$

- embedded fin

$$
w_{b f}=0.94 W_{s f}
$$




\section{Extruded Fin Algorithms}

The weight of the material in the extruded fin $\left(W_{e f}\right)$ can be estimated by calculating the weight of material in the fin and the material between the fins of the root as follows:

$$
W_{e f}=12 \pi\left[T_{m} P_{f} H_{f}\left(D_{r}+H_{f}\right)+\left(D_{\ell}+T_{r}\right) T_{r}\right] \rho_{f}
$$

Plate Fin Algorithms

Fin material weight for plate fins is based on a proportionate amount of fin per liner tube, although several liner tubes may extend through one plate. The spacer collars around the liner tube are also included in the following relationship.

$$
W_{p f}=12\left[A_{p} T_{s} P_{f}+\pi\left(D_{l}+T_{r}\right) T_{r}\right] \rho_{f}
$$

\section{Shear-Raised Fin Algorithms}

These algorithms are not presently developed.

Nomenclature

Terms used in fin weight algorithms are defined as follows:

$$
\begin{aligned}
\rho_{f} & \left.=\text { density of fin material (1b/in. }{ }^{3}\right) \\
T_{s} & =\text { thickness of fin stock (in.) } \\
T_{m}= & \text { mean thickness of extruded fin (in.) } \approx\left(0.028-0.01 P_{f}\right. \text { ) } \\
= & \text { fin section area divided by } H_{f} \\
T_{r}= & \text { thickness of material between fins (in.) } \\
& (\approx 0.035 \text { inch for extruded, wrap-on and plate fins) } \\
P_{f}= & \text { fin pitch (no./in.) } \\
H_{f}= & \text { height of fins (in.) } \\
D_{l}= & \text { OD of liner (in.) }
\end{aligned}
$$




$$
\begin{aligned}
& D_{r}=\text { fin root diameter (in.) }=D_{\ell}+2 T_{r} \\
& A_{p}=\text { area of each plate fin, width } \times \text { height (in. }{ }^{2} \text { ) } \\
& =P_{t}^{2} \text { for triangular spaced tubes } \\
& P_{t}=\text { tube pitch (in.) }
\end{aligned}
$$

Using the cost algorithms and cost data presented above, plots for single and double-footed wrap-on fin costs versus liner diameter were developed and are shown in Figure 3-10. The costs are for 10 fins per inch and the maximum fin heights which are commercially available for each liner size. When the tubing costs from Figures 3-4 or 3-5 are added to these finning costs and the sum divided by the finned tube surface area, the results are the minimum unit surface costs. Figure 3-11 shows minimum unit surface costs for wrap-on finned tubes with steel and admiralty liners. The costs do not include the spacers or element end preparation.

\subsubsection{Surface Coatings}

Several types of coating, such as epoxy or polyurethane for aluminum fins or galvanizing for steel fins, may be applied for protection. Coating costs are assumed to be proportional to the area being coated.

Thus,

$$
\text { protective coating costs }\left(C_{C}\right)=C_{c m} A_{S}+C_{C}^{\prime}=\$ / f t
$$

where

$$
\left.\begin{array}{l}
C_{\mathrm{cm}}=\text { coating material costs }\left(\$ / f t^{2} \text { of surface }\right) \\
C_{C}^{\prime}=\text { fixed coating costs }(\$ / f t)
\end{array}\right\} \begin{aligned}
& \text { These costs not } \\
& \text { developed }
\end{aligned}
$$




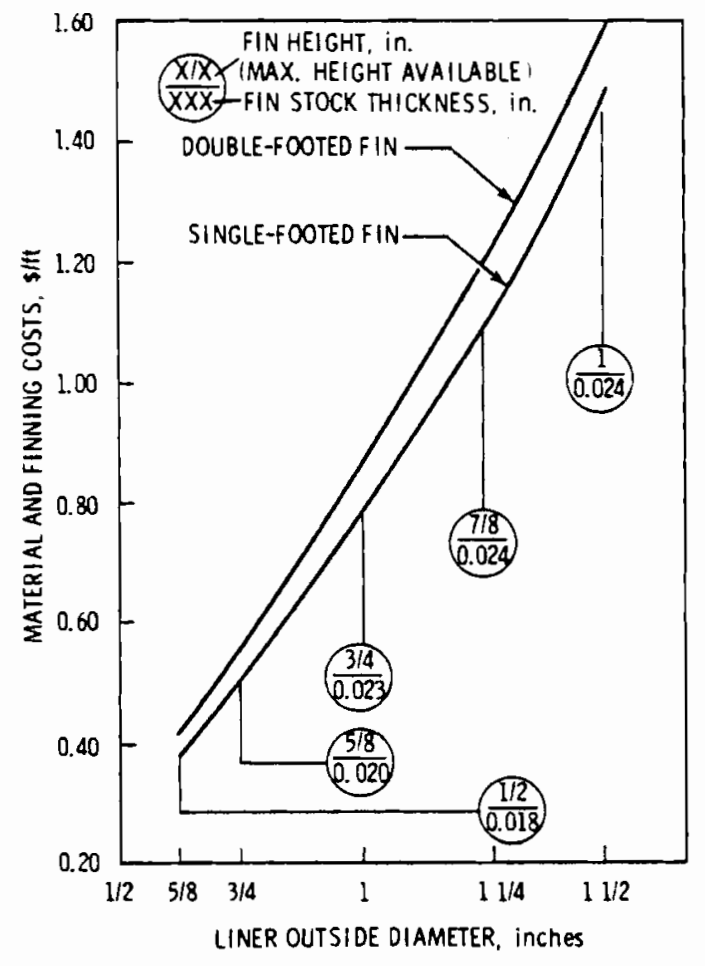

FIGURE 3-10. Finning Unit Costs for 10 Fins Per Inch, Liner Not Included

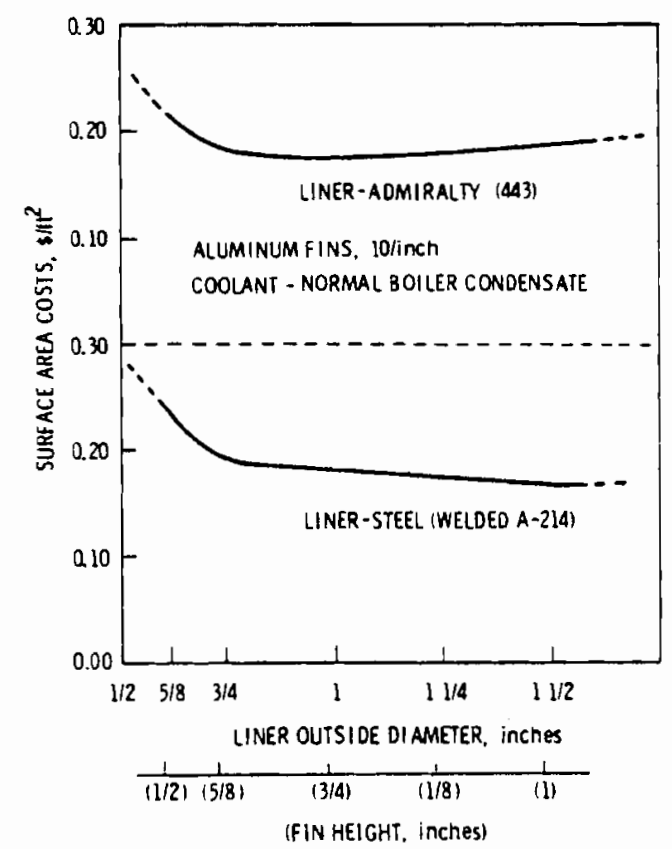

FIGURE 3-11. Wrap-On Finned Tube Minimum Unit Surface Costs for 10 Fins Per Inch 
where

$$
\begin{aligned}
& D_{r}=\text { fin root diameter (in.) } \\
& D_{f}=\text { fin OD (in.) } \\
& P_{f}=\text { fin pitch (no./in.) }
\end{aligned}
$$

\subsubsection{Bundle Element Spacers}

Spacers for the metal finned tube and plastic heat exchangers were considered in this analysis.

\subsubsection{Metal Finned Tube Spacers}

Spacers used for metal finned tubes are generally zinc rings about $1 / 2$ inch wide, cast directly onto the finned tube. These rings are also cast onto the finned section ends to serve as fin locking collars for wrap-on type fins. (See Section 3.2.5.)

$$
C_{s p} \text {, ring material and casting costs }=C_{z} \frac{\left(P_{t}^{2}-D_{r}^{2}\right)}{10}+C_{s}^{\prime}
$$

where

$$
\begin{aligned}
& C_{z}=\text { zinc material costs }(\$ / 1 b) \text { Use } \$ 0.50 / 1 b ; \text { refer to Appendix } D \\
& C_{s}^{-}=\text {casting costs }(\$ / \text { each) Use } \$ 0.25 / \text { each; refer to Appendix } C \\
& P_{t}=\text { tube pitch (in.) } \\
& D_{r}=\text { fin root diameter (in.) }
\end{aligned}
$$

\subsubsection{Plastic Tube Spacers}

The spacers for the plastic tube heat exchangers are envisioned to be one-piece perforated plastic sheets with the holes patterned to give the desired tube spacing. Because this sheet is a molded product, the holes can be shaped to match any tubing shape. The cost of the material per spacer per tube can be expressed as: 


$$
C_{s p} \text {, spacer costs }(\$ / \text { spacer } / \text { tube })=C_{p}\left(P_{t} \frac{H_{d}}{R}-A_{t}\right) t_{s p} \rho_{s}
$$

where

$$
\begin{aligned}
C_{p}= & \text { unit plastic costs }(\$ / 1 b) \text { (see Appendix } E \text { ) } \\
= & \$ 2.20 / 1 b \text { for foamed polycarbonate plastic with } 10 \% \text { glass fibers } \\
= & \$ 1.57 / 1 b \text { for PVC plastic } \\
P_{t}= & \text { tube pitch along bundle width (in.) } \\
H_{d}= & \text { header depth (in.) - see Section } 3.3 \\
R= & \text { number of tube rows in bundle } \\
A_{t}= & \text { tube cross section area }\left(i n .^{2}\right) \\
= & \pi / 4 D_{l}^{2} \text { for round tubes } \\
t_{S P}= & \text { thickness of spacer sheet (in.) } \\
& \text { suggested thickness }=D_{l} \\
\rho_{S}= & \text { density of the plastic used in the spacer (1b/in. }{ }^{3} \text { ) } \\
= & 0.0314 \text { for foamed polycarbonate with } 10 \% \text { glass fibers } \\
= & 0.044 \text { for PVC }
\end{aligned}
$$

\subsubsection{Tube End Preparation}

Tube end preparation consists of cutting the tube to the desired length, attaching locking collars at the ends for wrap-on fins, and machining the ends for rolling into the tube sheet. This cost $\left(C_{e}\right)$ is assumed a constant for each tube.

$$
c_{e} \approx \$ 1.00 / \text { tube (estimated for all finned tubes) }
$$




\subsubsection{Total Bundle Surface Costs}

Summing the unit costs developed in the previous section gives the following total unit costs $\left(C_{s}, \$ / f t\right.$ of tube) for the heat transfer elements.

$$
c_{s}=c_{l}+c_{f}+c_{c}+\left(\frac{C_{s p}}{s_{s}}-c_{s p}\right)+\frac{c_{e}}{L_{B}}
$$

The total surface costs for each bundle $\left(C_{S B}\right.$, $\$ /$ bundle $)$ can be calculated as follows:

$$
C_{S B}=L_{B} N_{B} C_{S}
$$

Terms used in the immediately preceding two equations are defined below.

$$
\begin{aligned}
& C_{l}=\text { liner costs }(\$ / \mathrm{ft}) \text { - see Section } 3.2 .1 \\
& C_{f}=\text { finning costs }(\$ / \mathrm{ft})-\text { see Section } 3.2 .2 \\
& C_{C}=\text { protective coating cost }(\$ / \mathrm{ft}) \text { - see Section } 3.2 .3 \\
& C_{s p}=\text { tube spacer costs }(\$ / \text { spacer }) \text { - see Section } 3.2 .4 \\
& C_{e}=\text { tube end preparation costs }(\$ / \text { tube }) \text { - see Section } 3.2 .5 \\
& N_{B}=\text { total number of tubes in bundle } \\
& L_{B}=\text { tube bundle length }(\mathrm{ft}) \\
& S_{S}=\text { tube spacer separation }(\mathrm{ft})
\end{aligned}
$$

\subsection{BUNDLE HEADER COSTS FOR WATER AND AMMONIA SERVICE}

\subsubsection{Tube Header Algorithms}

Headers distribute the fluid to be cooled to the individual coolant channels. The box header is commonly used for large air cooled modules in the air cooler industry. Several types are shown in Figure 3-12. Box headers may be classified into four general types for cost analysis: removable cover 

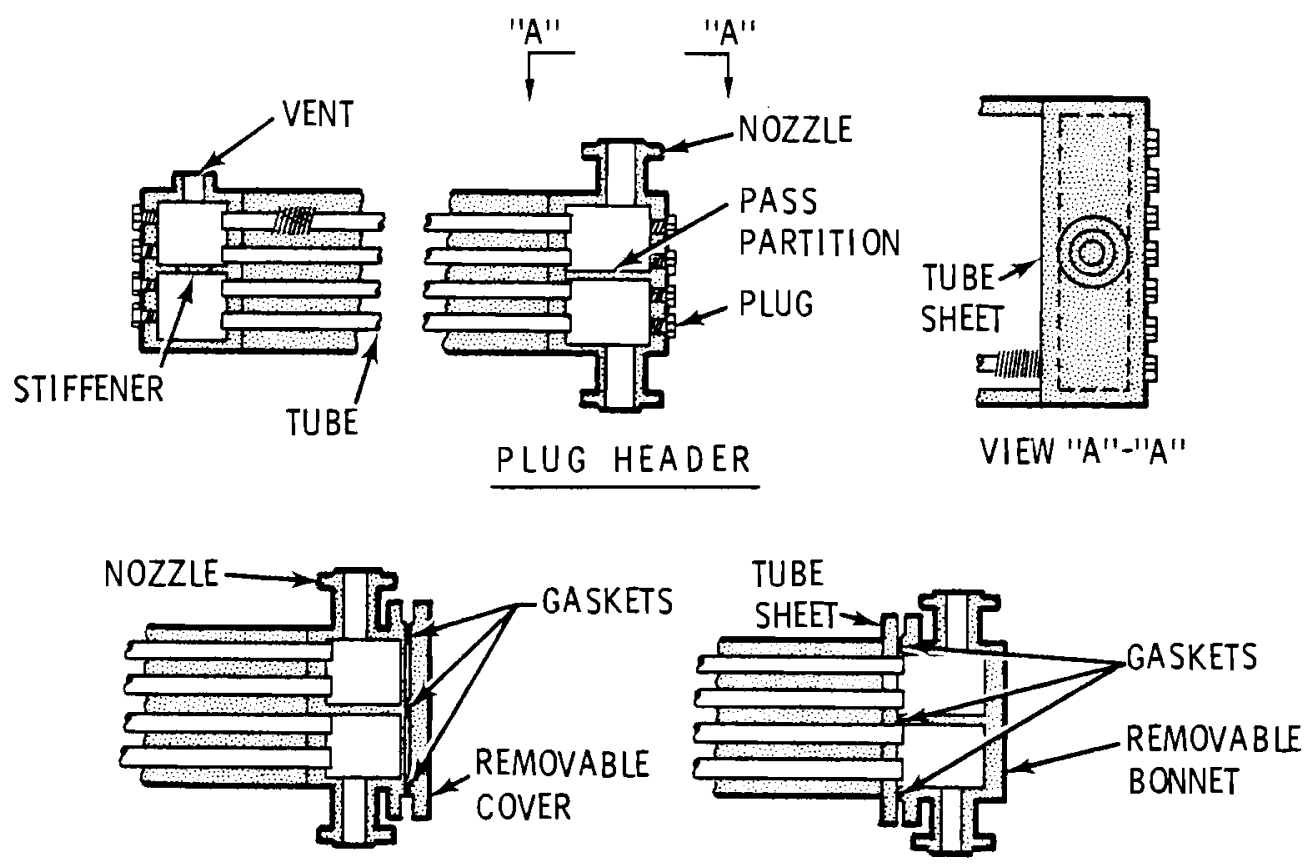

REMOVABLE-COVER HEADER REMOVABLE - BONNET HEADER
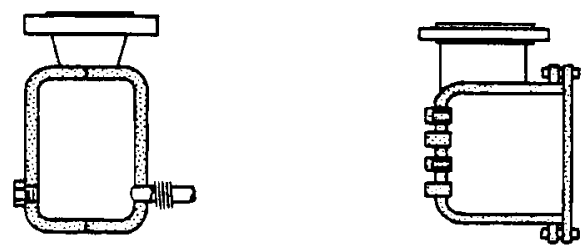

FORMED CHANNEL HEADERS

FIGURE 3-12. Typical Box Header Designs Used in Dry Cooling Tube Bundles

header, removable bonnet header, plug header, and totally closed header (no access for tube cleaning). Each type can be further classified as all-welded box construction or formed channel box construction, as shown in figure 3-12. The formed channel header eliminates two longitudinal weld seams by starting with preformed channels. 
The box header manufacturing costs $\left(C_{H}\right)$ can be approximated as:

$$
\begin{aligned}
C_{H} & =\text { material and machining costs + welding costs } \\
& + \text { removable cover joint costs + tube hole costs } \\
& + \text { nozzle costs. }
\end{aligned}
$$

The header algorithm includes the costs of both bundle headers. The header size is determined by the tube flow area per pass $\left(F_{A}\right)$, the number of passes, and the header length. The header depth (tube sheet width) is a function of the tube row pitch and number of rows. Costs are also included for the tube holes in the tube sheet. These are machined with grooves for rolling in the metal tubes or are straight holes for the elastomer seal proposed for the plastic tube heat exchangers. Both configurations are illustrated in Figure 3-13. The plug and hole costs for the plug headers are estimated by adding 150 percent to the cost of the rolled joint hole. The nozzle costs include two nozzles welded to the header.

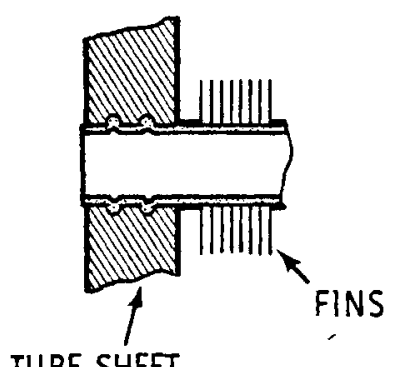

TUBE SHEET

$\frac{\text { ROLLED JOINT }}{\text { (METAL TUBES) }}$

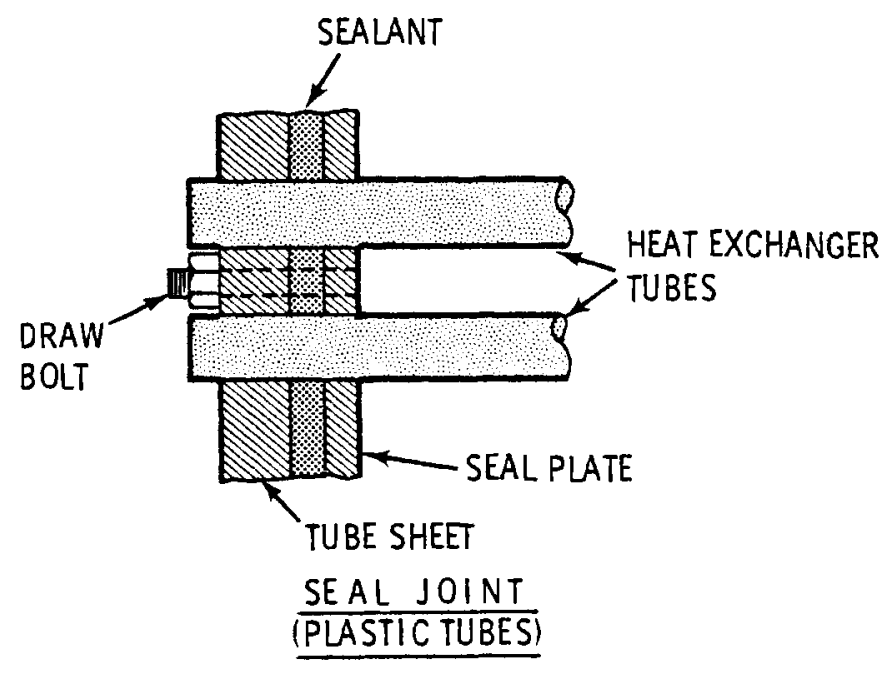

FIGURE $3-13$. Header to Tube Joints 
Based on the preceding criteria and the dimensions shown in Figure 3-14, the following algorithm was developed:

$$
\begin{aligned}
C_{H} & =C_{h m} \rho_{h m}\left\{12 W_{B}\left[4 H_{d}+2\left(N_{p}+1\right) H_{W}\right]+2 N_{p} F_{A}\right\}(f) t_{W} \\
& +C_{W}\left\{A W_{B}+\frac{1}{12}\left[8 H_{d}+4\left(N_{p}+1\right) H_{W}\right]\right\} \\
& +4 C_{F}\left(\frac{H_{d}}{12}+W_{b}\right)+C_{h h}\left(B N_{B}\right)+\left(C_{n}\right) 4 \sqrt{\frac{F_{A}}{\pi}}
\end{aligned}
$$

The following definitions and values apply to the above algorithm:

$$
\begin{aligned}
& t_{w}=\text { average header material thickness (in.) } \\
& t_{w} \text { (formed channel welded header) }{ }^{(a)} \\
& \text { Maximum Steel Headers, ATuminum Headers, } \\
& \text { Pressure } \\
& 100 \text { psi } \\
& \text { (water) } \\
& 350 \text { psi } \\
& \left(\mathrm{NH}_{3}\right) \\
& 450 \text { psi } \\
& \left(\mathrm{NH}_{3}\right) \\
& \frac{\text { in. }}{5 / 8} \frac{\text { in. }}{3 / 4} \\
& 1 \quad 1-1 / 2 \\
& 1-1 / 8 \quad 1-5 / 8
\end{aligned}
$$

(a) Based on a 6-inch deep by 8 -inch wide flow area

For steel headers, $t_{w}$ can be approximated as $t_{w} \approx 0.500+0.0014(P)$. For aluminum headers, $t_{W} \approx 0.500+0.0027(P)$. In both approximations, $P=$ maximum header pressure ( $p s i)$.

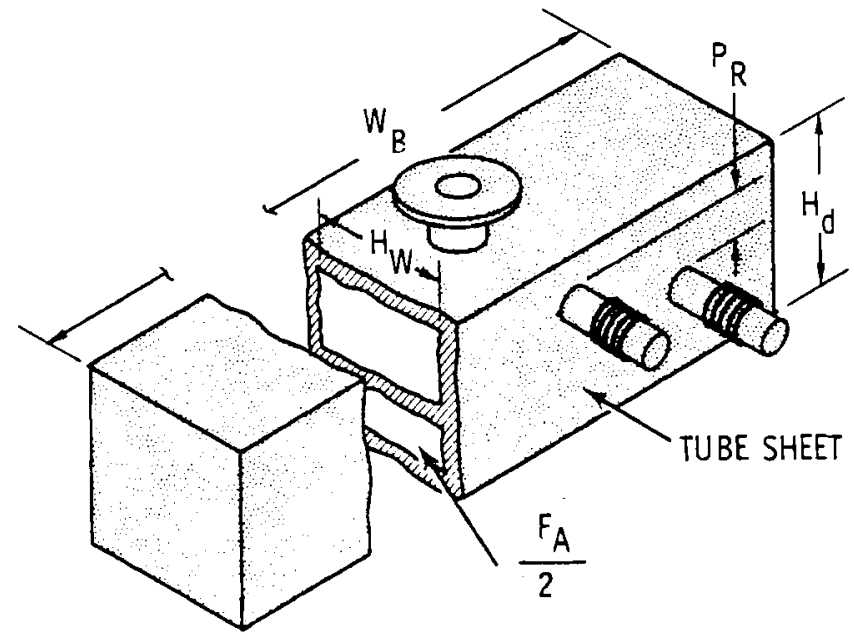

FIGURE 3-14. Dimensions Used in Header Cost Algorithm 
Additional terms in the algorithm are defined as:

$f=$ header size material thickness correction

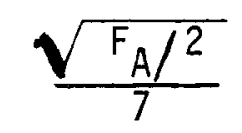

$$
\begin{aligned}
& \rho_{\mathrm{hm}}=0.284 \mathrm{lb} / \mathrm{in}^{3} \text { for steel headers } \\
& =0.0975 \mathrm{lb} / \mathrm{in}^{3} \text { for aluminum headers } \\
& N_{p}=\text { number of flow passes in bundle } \\
& H_{d}=\text { header depth (in.) } \\
& \approx\left(P_{R} R_{p}+1\right) N_{p}+2(f) t_{w} \\
& H_{w}=\text { header width (in.) } \\
& \approx \frac{F_{A}}{2\left(P_{R} R_{p}+1\right)} \\
& W_{B}=\text { header length }(\mathrm{ft}) \\
& \text { = bundle width } \\
& P_{t}=\text { tube pitch (in.) } \\
& P_{R}=\text { tube row spacing (in.) } \\
& R_{p}=\text { number of tube rows per pass } \\
& R=\text { number of tube rows in bundle }=N_{p} R_{p} \\
& N_{B}=\text { total number of tubes in bundle } \\
& \approx \frac{12 R W_{B}}{P_{t}} \\
& F_{A}=\text { total tube flow area per pass }\left(\text { in. }{ }^{2}\right. \text { ) } \\
& =\text { (liner tube flow area) (number of tubes per pass) } \\
& A=\text { longitudinal weld factor } \\
& =4\left(N_{p}+1\right) \text { for al1-welded header } \\
& =4 N_{p} \text { for formed channel header }
\end{aligned}
$$


$B=$ hole factor $=1$ for all except plug headers

$=2.5$ for plug headers

$C_{W}=$ cost of header welding and inspection $(\$ / f t)$

$=\$ g\left(t_{w}\right)(f) / f t$ minimum inspected (see Appendix $F$ )

$C_{n}=$ cost of nozzle and attaching

(\$/in. of nozzle diameter)

$=\$\left(5+4 \sqrt{\frac{F_{A}}{\pi}}\right)$ for high pressure ammonia headers

see

$=\$\left(3+2 \sqrt{\frac{F_{A}}{\pi}}\right)$ for low pressure water headers

Appendix D

$C_{h h}=$ cost of tube hole preparation ( $\$ /$ hole)

$\left.\begin{array}{l}=\$ 0.10 / \text { tube (plastic tubing) } \\ =\$ 1.00 / \text { tube (rolled joint) }\end{array}\right\}$ estimated

$C_{f}=$ added cost of bolted header joint $(\$ / f t)$

$=\$ 5 / \mathrm{ft}$ for removable cover or bonnet headers

$=\$ 0 / \mathrm{ft}$ for all-welded construction

$c_{h m}=\$ 0.53 / 1 \mathrm{~b}$ for nongalvanized steel headers

$=\$ 0.57 / 1 \mathrm{~b}$ for galvanized steel headers

see Appendix D

$=\$ 1.30 / 1 \mathrm{~b}$ for aluminum headers

\subsubsection{Elastomer Sealed Tube Joint Algorithms}

The method proposed for sealing plastic tubes to the header tube sheet consists of a double-plate tube sheet separated about $1 / 2$ to $3 / 4$ inch with the space filled with a sealing elastomer as shown in Figure $3-13 .{ }^{(14)}$ To assist sealing, the elastomer can be compressed slightly after setup by pulling the tube sheet plates together with draw bolts.

Costs of the second steel tube sheet and elastomer are approximated for the bundle as shown below.

$$
C_{S E}=[\text { cost of steel sheet }+ \text { cost of elastomer }] 2
$$




$$
c_{S E}=\left\{C_{S p} \rho_{s} t_{S p} 12 w_{B} H_{d}+c_{e} \rho_{e} t_{e}\left[12 w_{B} H_{d}-N_{B} A_{t}\right]\right\} 2
$$

where

$$
\begin{aligned}
& C_{S p}=\text { cost of seal plate } \approx \$ 0.53 / 1 b \text { (includes compression bolts, } \\
& \text { tube holes in header costs) } \\
& t_{s p}=\text { seal plate thickness }=1 / 4 \text { in. } \\
& \rho_{s}=\text { steel density }=0.284 \mathrm{lb} / \mathrm{in}^{3} \\
& \left.\begin{array}{l}
\left.W_{B}=\text { header length ( } f t\right) \\
H_{d}=\text { header depth (in.) }
\end{array}\right\} \text { see header algorithm } \\
& N_{p}=\text { number of passes in bundle } \\
& C_{e}=\text { cost of elastomer }=\$ 2.50 / 1 b \text { (estimated) } \\
& \rho_{e}=\text { elastomer density }=0.040 \mathrm{lb} / \mathrm{in}^{3} \text { (polyurethane) } \\
& t_{e}=\text { thickness of elastomer layer (in.) }=1 / 2 \text { in. } \\
& N_{B}=\text { number of tubes in bundle } \\
& =\frac{12 R W_{B}}{P_{t}} \\
& A_{t}=\text { tube cross section area }\left(\text { in. }{ }^{2}\right) \text {. }
\end{aligned}
$$

\subsection{BUNDLE FRAMES FOR HORIZONTAL AND VERTICAL TOWERS}

The bundle frame consists of two side frame members, usually channel beams, and cross support members as was shown in Figure 3-1. The side channels run the length of the bundle and connect to the headers but must allow relative movement between the headers due to the thermal expansion of the tube bundle. The side channels, together with the cross supports and cross bracing, form a rigid tube bundle that can be transported and fieldassembled as a unit. 


\subsubsection{Bundle Frame Algorithms}

The following algorithm was developed for tube bundle frame costs when the bundles are used in the horizontal position. This relation could also be used to estimate A-frame arrangements.

$$
C_{H F}=C_{S t}\left(50 L_{B}+10 W_{B} \frac{L_{B}-S_{S}}{S_{S}}\right) \frac{\sqrt{N_{p} F_{A}}}{8} \quad\{\text { horizontal bundle }
$$

This relation assumes the frame is supported by vertical structure columns as necessary. The frame weight and thus the bundle frame cost varies approximately as the square root of the bundle size, based on tube flow area, $F_{A}$.

The bundle frame for vertically positioned bundles consists of side channels and necessary bracing and support members. For a 12-foot wide $x$ 62-foot long bundle in the vertical position, the weight of the steel side channels, diagonal and wind bracing was calculated to be 4749 and 1456 pounds, respectively.

The following cost algorithm was developed for frames of vertical bundles.

$$
C_{V F}=C_{S t} L_{B}\left(77+2 W_{B}\right)\{\text { vertical bundle }
$$

For plastic surface bundles with plastic sheet spacers, 1/2-inch diameter steel spacer support rods will be required. These run the length of the bundle on 18-inch centers at both faces to support the plastic spacers. This requires an additional 580 pounds of steel. The following algorithm can be used for costing frame components (frame assembly not included) for vertical bundles 50 to 100 feet long with plastic spacers:

$$
C_{V P}=C_{s t} L_{B}\left(86+2 W_{B}\right)\left\{\begin{array}{l}
\text { vertical bundle with plastic sheet } \\
\text { spacers }
\end{array}\right.
$$

Necessary bracing to the tower structure will be added for the longer bundie lengths and is included in the tower structure costs. 
The following definitions apply to the horizontal and vertical bundle frame al gorithms.

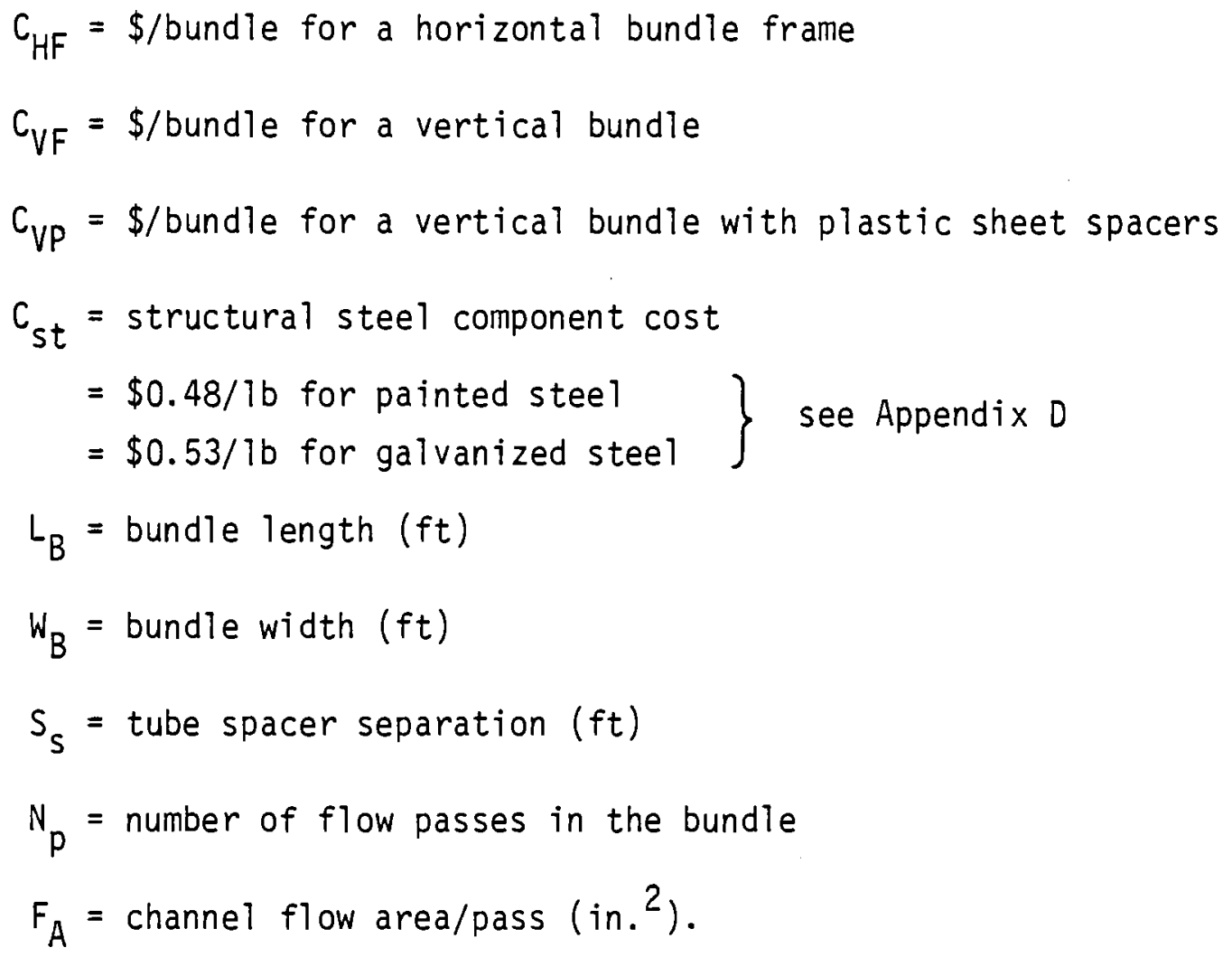

\subsection{BUNDLE ASSEMBLY COSTS}

Assembly consists of assembling the bundle frame and rolling, soldering, or welding the cooling channels into the header tube sheet.

\subsubsection{Finned Tube Bundle Assembly}

Generally the tubes are rolled into the tube sheet only, as shown in Figure 3-13. The tube assembly for tube bundles with ring spacers (Section 3.2.4) can be approximated with the following relation:

$$
C_{A}=\left(C_{r j}+C_{w j}\right) N_{B}
$$

where

$$
C_{A}=\text { tube bundle assembly cost ( } \$ / \text { bundle) }
$$




$$
\begin{aligned}
N_{B} & =\text { number of tubes in the bundle } \\
C_{r j} & =\$ / \text { tube for rolled joint } \\
& \approx \$ 1.00 / \text { tube (estimated) } \\
C_{w j} & =\$ / \text { tube for welded joint } \\
& \approx \$ 1.50 / \text { tube (estimated). }
\end{aligned}
$$

In some cases, the assembly may consist of both a rolled and welded joint to ensure integrity of the joint. The sum of $C_{r j}$ and $C_{w j}$ would be used in these cases.

\subsubsection{Plastic Tube Bundle Assembly}

Assembly of plastic tube bundles would require considerable labor because of the large number of individual tubes involved (approximately 3500 tubes/bundle). An assembly process with equipment designed to lay out the tubing and assemble these bundles would be economically justified in production. (15) Assembly can be divided into four steps:

1. Lay out tubing and assemble with spacers and tube sheets.

2. Attach spacers and tube sheets to the bundle side channels along with cross bracing.

3. Seal tubing to tube sheets (see Section 3.3).

4. Assemble bonnet to header and pressure-test bundle.

Cost of the first step, laying out the tubing and spacing the tube sheets and spacers along the bundle length, is dependent upon both the number of rows and bundle length. The second step cost is primarily dependent upon bundle length. The third and fourth steps will be treated as a function of bundle width.

Details of Step 1 and a cost analysis of the total bundle assembly have been developed and are shown in Appendix G. Cost of assembling a bundle 90 feet long and 12 feet wide with 20 rows of tubes was estimated at $\$ 2700$ for a full production shop working two shifts full-time. The percentage of this cost is estimated for each assembly step as follows: 


$$
\begin{array}{lll}
\text { Step } 1 & -50 \% \text { or } \$ 1350 \\
\text { Step } 2 & -30 \% \text { or } & 810 \\
\text { Step } 3 \text { and } 4 & -20 \% \text { or } & 540 \\
& &
\end{array}
$$

Developing an assembly cost relation based upon the bundle size and bundle tube rows leads to:

$$
C_{b a}=1150 \frac{\sqrt{R L_{B}}}{42}+650 \frac{\sqrt{L_{B}}}{9.5}+400 \frac{\sqrt{W_{B}}}{3.5}+500
$$

where

$$
\begin{aligned}
C_{b a} & =\text { assembly cost per bundle ( } \$ / \text { bundle) } \\
R & =\text { number of rows in the bundle } \\
L_{B} & =\text { length of the bundle }(\mathrm{ft}) \\
W_{B} & =\text { width of the bundle }(\mathrm{ft}) .
\end{aligned}
$$

The square root of the product of bundle tube rows and length is estimated to approximate the Step 1 cost variation with bundle size. Step 2 costs are mostly labor and thus are approximated with a length function. Steps 3 and 4 depend primarily on bundle width and can be treated as a function of bundle width.

\subsection{TOTAL HEAT TRANSFER BUNDLE COSTS}

The heat transfer bundle costs consist of costs for the total surface $\left(C_{S}\right)$, tube header $\left(C_{H}\right)$, seal plate and elastomer $\left(C_{S E}\right.$, for plastic tubes only), bundle frame $\left(C_{H F}, C_{V F}\right.$, or $\left.C_{V P}\right)$, and bundle assembly $\left(C_{A}\right)$. These costs, originating from manufacturing cost algorithms, are the manufacturer's material, labor, equipment, and job overhead costs. Therefore, the addition of the manufacturer's general overhead and profit is required. General overheads and profits of 10 percent each are used to provide the following total bundle cost f.o.b. the manufacturer's plant:

$$
C_{T B}=\left[\left(C_{S}+C_{H}+C_{F r}+C_{A}\right) 1.10\right] 1.10
$$


where

$$
\begin{aligned}
& C_{T B}=\text { total bundle cost }(\$) \text { f.o.b. manufacturer's plant } \\
& C_{F r}=\text { frame cost }(\$),\left(C_{H F}, C_{V F} \text {, or } C_{V P}\right)
\end{aligned}
$$

Cost of shipping and installation will be considered in Section 10.0.

\subsection{LOUVERS AND HAIL SCREENS}

\subsubsection{Louvers}

To control the air flow through the bundles and to aid in cold weather startup and operation, louvers are commonly used, particularly for forced draft fan systems and round towers with the bundles arranged vertically around the periphery. Louvers may be used for either intake or exhaust control. In both cases, the louvers generally are placed across the face of the bundle.

The cost of galvanized louvers for bundles has been determined to be about $\$ 4.20 / \mathrm{ft}^{2}$ of bundle face area. Cost of the pneumatic actuator is estimated at $\$ 0.83 / \mathrm{ft}^{2}$ and shutter installation at $\$ 2.00 / \mathrm{ft}^{2}$. Installation of the louvers will be accomplished at the site after erection of the bundle. The installed pneumatic system and controls are estimated at 15 percent of total louver costs. Louver, control, shipping, and installation costs for each bundle, expressed as a function of louver surface area, are:

Louver costs $\left(C_{L U}\right)=\left[\left(C_{\ell \mu}\right) 1.06+C_{\ell i}\right] A_{L U} 1.15$

where

$$
\begin{aligned}
C_{\ell \mu} & =\text { unit louver costs }=\$ 5.03 / \mathrm{ft}^{2}(1 \text { ouver costs } \\
& \left.-\$ 4.20 / \mathrm{ft}^{2} \text {, actuator costs }-\$ 0.83 / \mathrm{ft}^{2}\right) \\
C_{\ell i} & =\text { field installation unit costs }=\$ 2.00 / \mathrm{ft}^{2} \\
1.06 & =\text { cost factor for shipping } \\
1.15 & =\text { cost factor for controls } \\
A_{L U} & =\text { louver surface area/bundle }\left(\mathrm{ft}^{2}\right) \\
& =L_{B} W_{B} \text { if placed over face of bundle }
\end{aligned}
$$




$$
\begin{aligned}
& L_{B}=\text { length of bundle }(f t) \\
& W_{B}=\text { width of bundle }(f t) .
\end{aligned}
$$

Appendix $H$ provides detailed bases for louver costs.

\subsubsection{Hail Screens}

Hail screens are required in some geographical locations where damaging hail storms are experienced. Hail screens will not be required if louvers are installed. Hail screens are usually placed across the face of each bundle. Costs of hail screens are a function of screen area installed and can be estimated using the following function for coverage of each bundle face:

$$
c_{H S}=\left[\left(c_{h s}\right) 1.06+c_{i h s}\right] W_{B} L_{B}
$$

where

$$
\begin{aligned}
C_{H S} & =\text { assembled cost of hail screens }(\$ / \text { bundle) } \\
C_{h s} & =\text { hail screen material unit costs }(\$) . \\
& =\$ 1.32 / \mathrm{ft}^{2} \text { (galvanized expanded metal) } \\
1.06 & =\text { cost factor for shipping } \\
C_{i h s} & =\text { unit cost of installing hail screens } \\
& =\$ 0.50 / \mathrm{ft}^{2} \text { (field installed) } \\
W_{B} & =\text { bundle width }(\mathrm{ft}) \\
L_{B} & =\text { bundle length }(\mathrm{ft}) .
\end{aligned}
$$

Bases for hail screen cost estimates are also included in Appendix $H$. 



\subsection{MECHANICAL DRAFT EQUIPMENT}

\subsection{FAN SYSTEM}

Axial flow propeller-type fans are normally proposed to move the large volumes of air required to air-cool large power plants. These fans usually have four or more blades and range up to 32 feet in diameter. Larger fans up to 60 feet in diameter have been tested. The blades of the fans are usually either cast aluminum, fiberglass reinforced phenolic or epoxy laminates or a formed sheet metal structure of aluminum or stainless steel. Variation in the amount of air flow for a given fan can be obtained by adjusting either the blade angle or the speed of rotation. The blade pitch on large air cooler fans is either manualiy adjustable or auto-adjustable. Air flow rate and the required fan power are both dependent upon the blade pitch angle. The speed of rotation is changed by using multi-speed (usually twospeed) motors producing a stepped variation in air flow.

The fan system cost consists basically of the fan, drive, and the electrical and control equipment costs. This information is used by the computer subroutine FAN, which selects the most economical fan from several options. The fan selections range from 24 to 60 feet in diameter with from 6 to 16 blades. The fan is selected on the basis of least total annualized cost.

\subsection{FAN COSTS}

Fan costs depend primarily upon the diameter of the fan, the number of blades, and whether the fan has manual or auto-variable pitch control. Using one fan manufacturer's cost information, the following fan cost algorithm was developed:

$$
\text { Fan cost } \begin{aligned}
\left(C_{F A}\right) & =\text { blade costs }+ \text { hub and seal costs } \\
C_{F A} & =N_{b}\left(D_{F A} C_{b}+C_{b}^{-}\right)+C_{F A}
\end{aligned}
$$

where

$$
\begin{aligned}
& C_{F A}=\text { fan costs }(\$ / \text { fan }) \\
& N_{b}=\text { number of blades in fan }
\end{aligned}
$$




$$
\begin{aligned}
& D_{F A}=\text { fan diameter }(\mathrm{ft}) \\
& C_{b}=\text { unit costs of blade }(\$ / \mathrm{ft} \text { of fan diameter }) \\
& C_{b}^{\prime}=\text { blade cost constant }(\$ / b l a d e) \\
& C_{F A}=\text { hub and seal costs. }
\end{aligned}
$$

These costs were developed from a fan manufacturer's price list ${ }^{(16)}$ for use in the above equation. This information is presented in Table 4-1. The manufacturer's fan prices are f.o.b. the manufacturer's plant. Costs of

\begin{tabular}{|c|c|c|c|}
\hline $\begin{array}{l}\text { Fan Diameter } \\
\left(\mathrm{D}_{\mathrm{FA}}\right), \mathrm{ft}\end{array}$ & & & $C_{F A-}$ \\
\hline $16-20$ & 8.2 & 158 & 325 \\
\hline $21-30$ & 25.2 & -105 & 472 \\
\hline $31-32$ & 25.2 & -105 & 1900 \\
\hline $33-40$ & 25.2 & -105 & 4750 \\
\hline
\end{tabular}
shipping and installation are considered in Section 10.0 .

TABLE 4-1. Algorithm Cost Data for Manual Controlled Pitch Fans of Glass Reinforced Epoxy

\subsection{FAN EQUIPMENT COSTS}

Fan drive and equipment consist of driver, speed reducer, shaft, bearings and mounts. The driver is generally an electric motor while the speed reducers are $V$-belt drives for fans up to 10 feet in diameter requiring under $25 \mathrm{hp}$. Spiral bevel gear drives are used for the higher horsepower fans. The cost of this equipment is dependent upon horsepower requirements. Manufacturer's costs f.o.b. the manufacturer's plant can be expressed as follows:

$$
C_{F E}(\$ / f a n)=H P_{f m}\left(C_{S}+C_{m}\right)+H P_{f m}^{1.5}+C_{E}^{\prime}
$$

where

$$
\begin{aligned}
H P_{f m} & =\text { horsepower of fan motor } \\
C_{S} & =\text { speed reducer costs }(\$ / h p)
\end{aligned}
$$




$$
\begin{aligned}
\approx & \$ 55 / \mathrm{hp} \text { (spiral bevel gear) } \\
\approx & \$ 25 / \mathrm{hp} \text { (V-belt drive) } \\
C_{m}= & \text { fan motor costs }(\$ / \mathrm{hp})(17) \\
& \quad \begin{array}{l}
\text { (single speed induction motors totally } \\
\text { enclosed or weather protected) }
\end{array} \\
\approx & \$ 26.60 / \mathrm{hp} \text { for motors } 25 \text { to } 250 \mathrm{hp} \\
\approx & \$ 24.30 / \mathrm{hp} \text { for motors }>250 \mathrm{hp} \\
C_{E}= & \text { fan equipment constant } \\
= & \$ 1000 \text { for fans } 25 \text { to } 250 \mathrm{hp} \\
= & 9000 \text { for fans }>250 \mathrm{hp}
\end{aligned}
$$

\subsection{FAN PLENUMS}

The fan plenum chamber uniformly distributes the air over the heat exchanger unit face while smoothly changing the air velocity by a factor of 2 or 3 times. The type of plenum used depends upon whether the fan system is forced draft or induced draft. In the forced draft unit, the fan pushes the air through the surface. In the induced draft unit, the fan pulis the air through the cooling surface. Both types are depicted in Figure 4-1 for flat positioned heat exchanger units. Forced draft is used for the A-frame design while the fans are mounted in the top of the circular towers (Figure 3-2) producing induced draft systems. Induced draft fans generally give better air distribution through the heat exchanger while the forced draft design theoretically requires less power. This is because the forced draft fan "pumps" the air before it is heated in the heat exchanger while at the higher density.

Fan rings form an air seal at the blade tip reducing air recirculation and loss of fan efficiency. Fan performance is directly affected by the clearance between the blade tips and ring. This clearance must be kept to a reasonable minimum. 

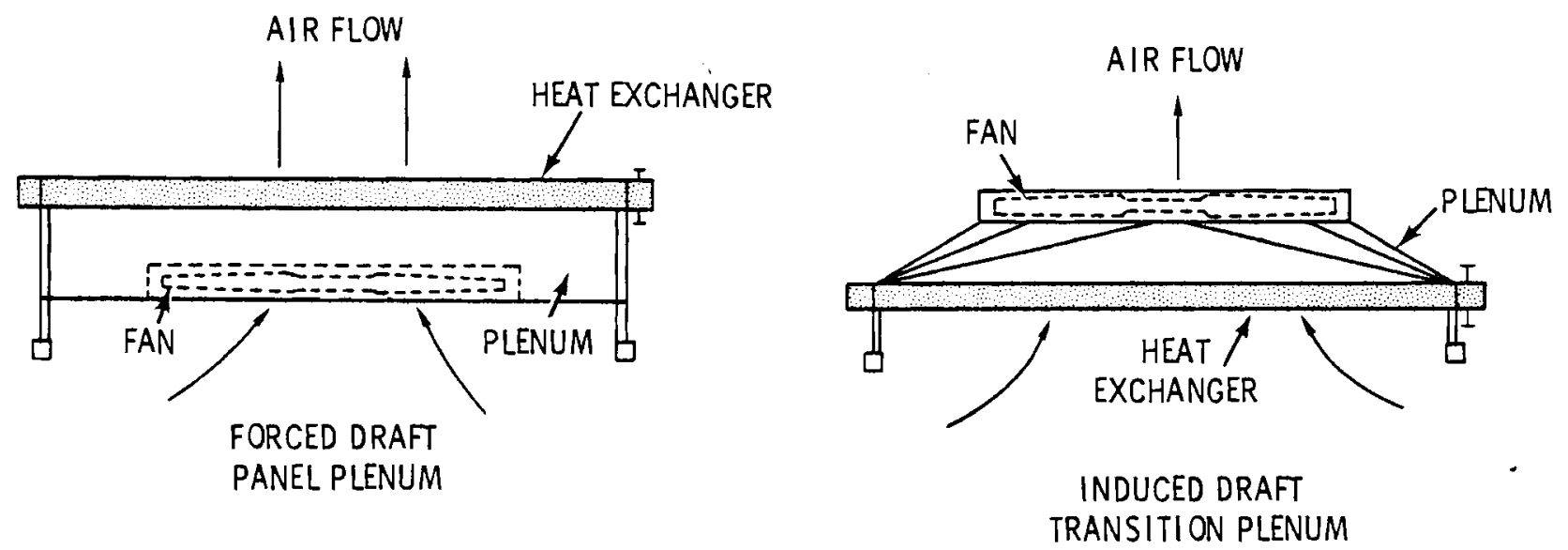

FIGURE 4-1. Typical Fan Plenum Arrangements

\subsubsection{Horizontal Heat Exchanger Plenums}

The rectangular panel or transition plenum is generally used for rectangular towers with the heat exchangers mounted in the horizontal configuration (either flat or open-Vee position) as shown in Figure 3-2. Either forced or induced draft fans may be used. Assuming a rectangular tower with dual fan rows, the cooler face area served by each fan is 2-1/2 times the fan area, the plenum chamber depth is about $1 / 2$ the fan diameter, and the fan ring is $1 / 6$ the fan diameter. These assumptions lead to the following relation to approximate the plenum costs, f.o.b. the manufacturer's plant and including 10 percent general overhead and 10 percent profit:

$$
C_{P L}(\$ / \text { fan })=\left[\begin{array}{lllll}
\left(A C_{p m}\right. & W_{p l} & D_{F A}{ }^{2} & 1.10
\end{array}\right] 1.10
$$

where

$$
\begin{aligned}
C_{p m}= & \text { cost } / 1 \mathrm{~b} \text { of plenum and ring including fabrication } \\
& \text { and protective coating }(\$ / 1 \mathrm{~b}, \text { see Appendix } \mathrm{D}) \\
\approx & \$ 0.50 / 1 \mathrm{~b} \text { for nongalvanized steel plenums and rings } \\
\approx & \$ 0.55 / 1 \mathrm{~b} \text { for galvanized steel plenums and rings } \\
1.10= & \text { factor for manufacturer's general overhead } \\
& \text { and profit } \\
W_{p l}= & \text { weight } / \mathrm{ft}^{2} \text { of plenum and ring including bracing } \\
& \text { and reinforcing }\left(1 \mathrm{~b} / \mathrm{ft}^{2}\right) \\
\approx & 4.6 \mathrm{bb} / \mathrm{ft}^{2}
\end{aligned}
$$




$$
\begin{aligned}
D_{F A}= & \text { diameter of fan }(f t) \\
A= & \text { factors for forced and induced draft fans } \\
\approx & 4.0 \text { forced draft fans } \\
& \text { (rectangular panel plenum) } \\
\approx & 3.5 \text { for induced draft fans } \\
& \text { (rectangular transition plenum) }
\end{aligned}
$$

\subsubsection{Vertical Heat Exchanger Plenums}

In circular towers with the induced draft fans mounted in the top, the fan plenum consists of the tower enclosure. The fan duct will normally include an inlet bel1 and a fan ring or velocity recovery stack (VRS). The VRS wi11 be considered in the next section. The cost of the tower enclosure is included as part of the structure costs discussed in Section 9.0. Assuming the inlet bell flares to a maximum diameter of about 12 percent greater than the fan diameter, and that both straight fan ring and inlet bell heights are about $1 / 6$ of the fan diameter (together are $1 / 3 D_{F A}$ ), leads to the following relation for estimating the cost f.o.b. manufacturer's plant.

where

$$
C_{E R}=\left[\left(1.08 C_{e r} W_{e r} D_{F A}{ }^{2}\right) 1.10\right] 1.10
$$

$$
\begin{aligned}
C_{E R}= & \text { cost of fan entry ring }(\$ / \mathrm{fan}) \\
1.10= & \text { factor for manufacturer's overhead and } \\
& \text { profit } \\
W_{\mathrm{er}}= & \text { unit weight of entry ring }\left(1 \mathrm{~b} / \mathrm{ft}^{2}\right) \\
\approx & 4.61 \mathrm{~b} / \mathrm{ft}^{2} \text { for galvanized stee } 1 \\
\approx & 2.51 \mathrm{~b} / \mathrm{ft}^{2} \text { for molded glass reinforced polyester } \\
D_{F A}= & \text { diameter of fan }(\mathrm{ft}) \\
C_{\mathrm{er}}= & \text { unit cost of entry ring including fabrication } \\
& \text { and coating } \\
\approx & \$ 0.55 / 1 \mathrm{~b} \text { for galvanized steel (see Appendix } \mathrm{D}) \\
\approx & \$ 1.83 / 1 \mathrm{~b} \text { for glass reinforced polyester }
\end{aligned}
$$




\subsection{FAN VELOCITY RECOVERY STACKS}

Fan velocity recovery stacks are used to recover some of the kinetic energy in the moving air stream at discharge from the induced draft fans. Velocity recovery stacks are of particular importance in installations in which a substantial portion of the fan power is used to accelerate the air velocity, as in cases where the heat exchanger face area is considerably larger than the fan area through which the air must pass. This can be experienced in both rectangular and circular towers.

Velocity recovery stacks consist of an inlet bell and a diffuser cylinder. They may be separated sections or an integrally fabricated assembly as one manufacturer's glass reinforced polyester unit which is molded in segments and, when assembled, forms an integral inlet bell and diffuser cylinder. Assuming that the inlet bell is dimensioned the same as described in Section 4.4.2, and that the diffuser height is about half the fan diameter with a flare going to a maximum diameter of 12 percent greater than the fan diameter, the following relation for estimating cost f.o.b. manufacturer's plant is provided:

$$
\begin{aligned}
& c_{\text {VRS }}=\left[\begin{array}{lllll}
\left(2.25 C_{\text {rrs }}\right. & \left.W_{\text {rrs }} D_{F A}{ }^{2}\right) & 1.10
\end{array}\right] 1.10 \\
& c_{\text {VRS }}=\text { cost velocity recovery stack }
\end{aligned}
$$

where

$$
\begin{aligned}
W_{r r s} & =\text { unit weight of } \operatorname{VRS}\left(1 \mathrm{~b} / \mathrm{ft}^{2}\right) \\
& \approx 4.61 \mathrm{~b} / \mathrm{ft}^{2} \text { for galvanized steel } \\
& \approx 2.51 \mathrm{~b} / \mathrm{ft}^{2} \text { for glass reinforced plastic } \\
D_{F A} & =\text { diameter of the fan }(\mathrm{ft}) \\
C_{r r s} & =\text { unit cost of VRS material }(\$ / 1 \mathrm{~b}) \\
& \approx \$ 0.55 / 1 \mathrm{~b} \text { for galvanized steel (see Appendix } \mathrm{D}) \\
& \approx \$ 1.83 / 1 \mathrm{~b} \text { for glass reinforced plastic } \\
1.10 & =\text { cost factor for manufacturer's overhead and profit. }
\end{aligned}
$$




\subsection{CIRCULATION SYSTEM}

Any high cost component in the cooling system of a large electric generating station is going to weigh heavily in the tradeoffs that result in an economically optimum cooling system design. Therefore, each of these components must be modeled with sufficient detail to define its respective costs as completely and accurately as possible. In this way, the final design will adequately reflect the true optimum. The piping system falls into this group as it can represent as much as 25 percent of the total capital costs of the cooling system. Consequently, careful attention has been given to the development of a comprehensive piping model. This section describes the resulting model and its development.

Development of the piping system design and cost model was constrained by two considerations. First, preference was given to components or design features that would likely be required or offered by industry. Second, the generalized design had to be readily adaptable to computer modeling.

The piping model presented here is believed to be of sufficient detail to accurately define the cost of the piping system. An actual power plant layout would probably differ somewhat from the design used in the modeling. However, the predicted costs should still be representative of what would be paid for such a piping system in 1976 dollars. To this extent, the model is considered capable of defining an optimized piping system.

\subsection{PIPING SYSTEM DESCRIPTION}

Two cooling tower arrangements were considered for dry type cooling systems: circular towers and rectilinear towers. Circular towers are characterized by vertical tube bundles. For a 1000-Mwe power station there would typically be several circular towers supplied from one main header. The rectilinear tower could have the tube bundles anywhere from horizontal to vertical although most designs show the tube bundles to be within a few degrees of horizontal. A single rectilinear tower would be supplied by one main header. 
A piping system design and cost model was developed for a cooling system using water and for one using ammonia as the primary coolant. A one-pass vertical heat exchanger was chosen for the ammonia system. With vapor entering at the top of the tube bundle it facilitates condensate collection. Thus, the ammonia lends itself to the circular tower arrangement. To compare the ammonia and water systems on an equivalent basis, a circular tower piping model was also developed for the water systems. In addition, a rectilinear tower piping mode 1 was developed for metal finned tube system analysis.

Plant shutdown, system repair or freeze protection would necessitate draining the coolant from the heat exchanger and storing it until the problems were corrected. However, such a drain and refill system has not been included in the piping model for the following reasons:

- Cost data on some of the required components was thought to be inadequate, particularly with regard to the storage tanks.

- Site-specific issues have not been dealt with in this study. Therefore, drain and refill systems were excluded in all cases for design comparison purposes.

- Because there was little operating history on this subject, it was not clear what capacity would be required at any particular site.

A drain and refill system with capacity to store the entire volume of coolant could add as much as 20 percent to the cost of the piping system. If attempts were made to optimize the cooling systems for a particular site, then the costs should be included because they would influence the optimization results.

\subsubsection{Circular Towers}

The piping system model for circular towers consisted of the pump station, quadrant piping, tower distribution piping and main circulation piping. They are identified in Figure 5-1, drawn for a four-tower arrangement. The piping layout shown is representative of the configuration modeled in the piping system design and cost algorithm. This figure represents either the supply piping from the condenser to the heat exchangers or the return piping from the heat 

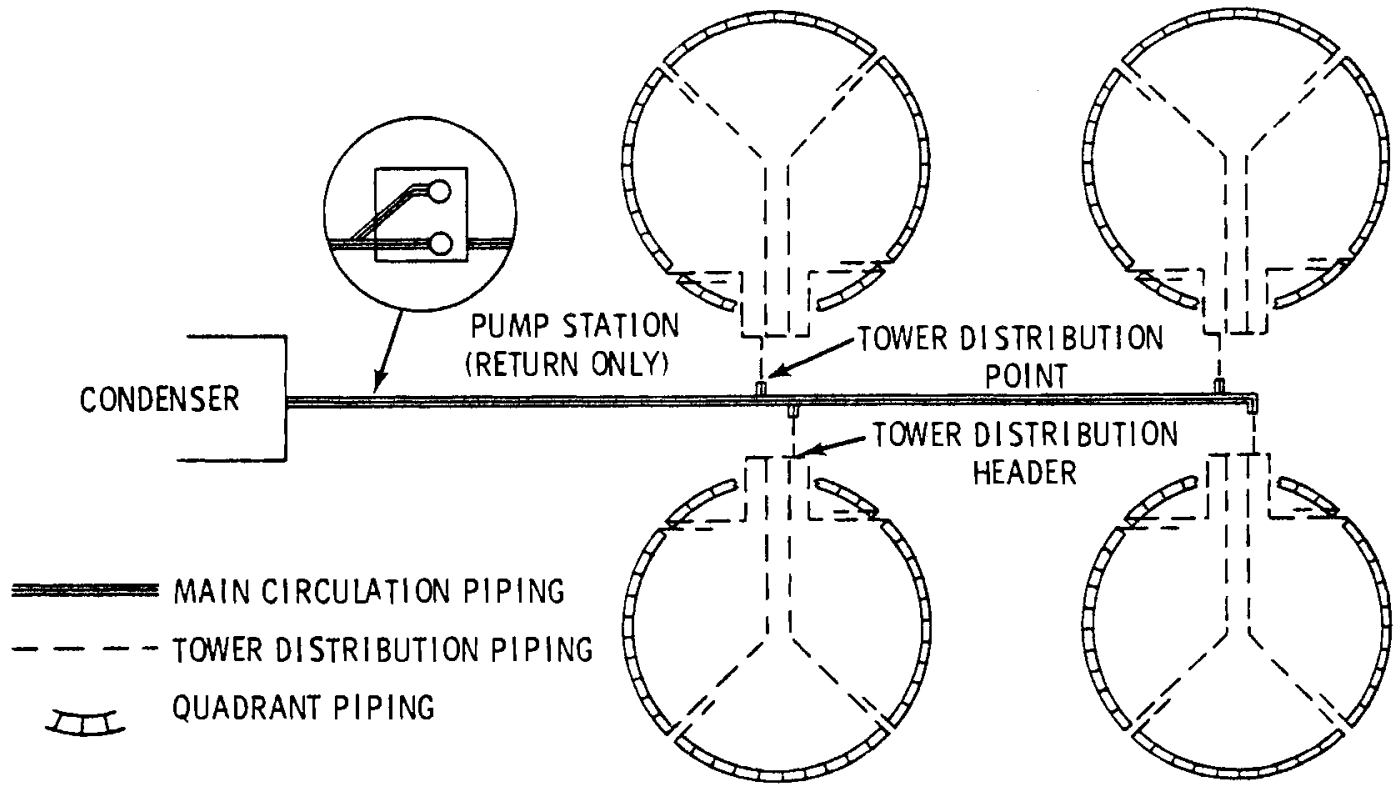

FIGURE 5-1. Piping Subsystems for Circular Towers

exchangers to the condenser. Only one is shown because it was assumed that the layout of the supply and return piping could be essentially identical. Some adjustments are necessary, however, because the pump station is assumed to be included in the return piping. Also, for ammonia systems the supply coolant is a vapor and the return coolant is a liquid. The different densities and allowable design velocities result in different pipe sizes for the supply and return piping of the ammonia systems. A slightly different quadrant piping arrangement is required for the ammonia. This is discussed in Section 5.1.1.2.

\section{1 .1 .1 Pump Station}

The pump station for the water system is in the return line of the main circulation piping. It is assumed to be 50 feet in length from inlet to outlet. Two vertical inline pumps provide the capacity of the main circulation line. At the outlet of each pump is a motor-operated valve and an expansion joint. Other appropriate pipe and fittings are included in the pump station costs. No auxiliary pumping capability is provided. 


\subsubsection{Quadrant Piping}

The flow to each tower is distributed to four quadrants regardless of tower size. The supply and return quadrant headers interface with the tower distribution piping at opposite ends of the quadrant. Figure 5-2 shows the quadrant headering for the water system, modeled with a two-pass heat exchanger. This enables the supply and return quadrant headers to be located at ground level. The ammonia system is modeled with a one-pass heat exchanger. The supply vapor is piped to the top of the quadrant where it is distributed to the heat exchanger bundles. The ammonia condensate is collected in a return header similar to the return header of a water system.

The quadrant header includes pipe, reducers and a tee at each tube bundle. The pipe and flanges connecting the header tees to the bundles are added to the quadrant headering costs.

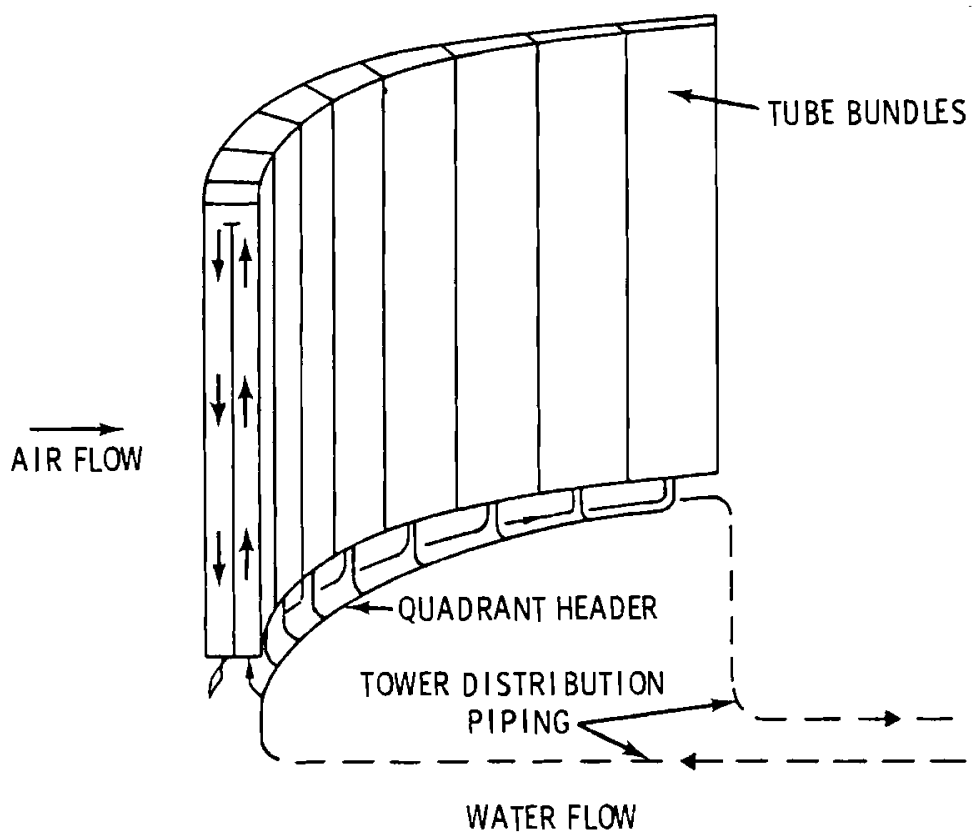

FIGURE 5-2. Quadrant Headering for Water System 


\subsubsection{Tower Distribution Piping}

The tower distribution piping is composed of the pipe and fittings from the tower distribution point to the quadrant headers. The flow is routed to each quadrant through the tower distribution header. Cooling system control is maintained by motor-operated valves located in the supply and return lines to each quadrant.

\subsubsection{Main Circulation Piping}

The main circulation piping includes the pipe and fittings from the condenser outlet flange to the distribution point for each circular tower. This piping is assumed to be entirely underground. The interface between the condenser and the piping system is a flanged expansion joint. The straight run of pipe from the condenser also includes the tees at each tower distribution point and appropriately sized reducers. The distribution point of the last tower is equipped with an elbow.

\subsubsection{Rectilinear Towers}

Many features of the rectilinear tower piping model are similar to the features of the circular tower piping model. Three subsystems have been identified and are shown in Figure 5-3. These are the pump station, module piping and main circulation piping. The functions of the tower distribution and quadrant piping in the circular tower model are combined here into the module piping. The supply piping from the condenser outlet to the heat exchanger inlet and the return piping from the heat exchanger to the condenser are identical except that the pump station is in the return line of the main circulation piping.

The rectilinear piping model was developed for the water systems only. The rectilinear towers are modeled with two-pass horizontal heat exchanger bundles.

\subsubsection{Pump Station}

The pump station models for the rectilinear and circular tower arrangements are exactly identical (see Section 5.1.1.1). 


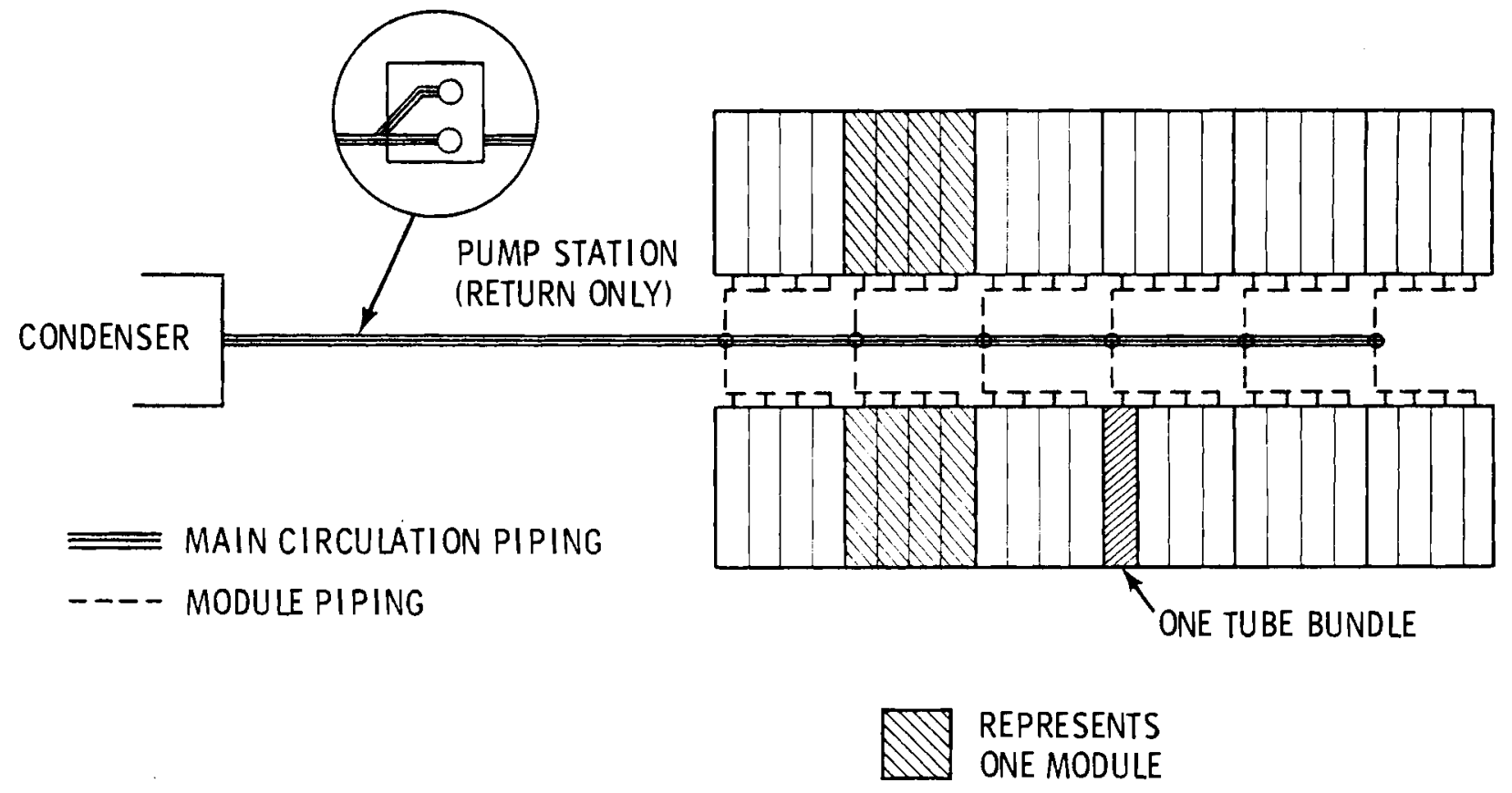

FIGURE 5-3. Piping Subsystems for Rectilinear Towers

\subsubsection{Module Piping}

The module piping is shown in Figure 5-4. A module is composed of two opposed banks of horizontal tube bundles. There is an equal number of bundles in each bank. The total number of bundles in a module is variable. The number of modules per tower depends upon the total flow to the tower and the number of bundles per module.

The modules stand 50 feet above the main circulation header. Coolant is supplied to the module through a riser, which divides the flow equally to each tube bank. The return system is similar. The valves on the supply and return risers isolate the flow to the module.

The module headers are similar to the quadrant headers for circular towers. The supply and return lines are at opposite ends of the module. The comments in Section 5.1.1.2 regarding quadrant headers apply to the components of the module headers. 


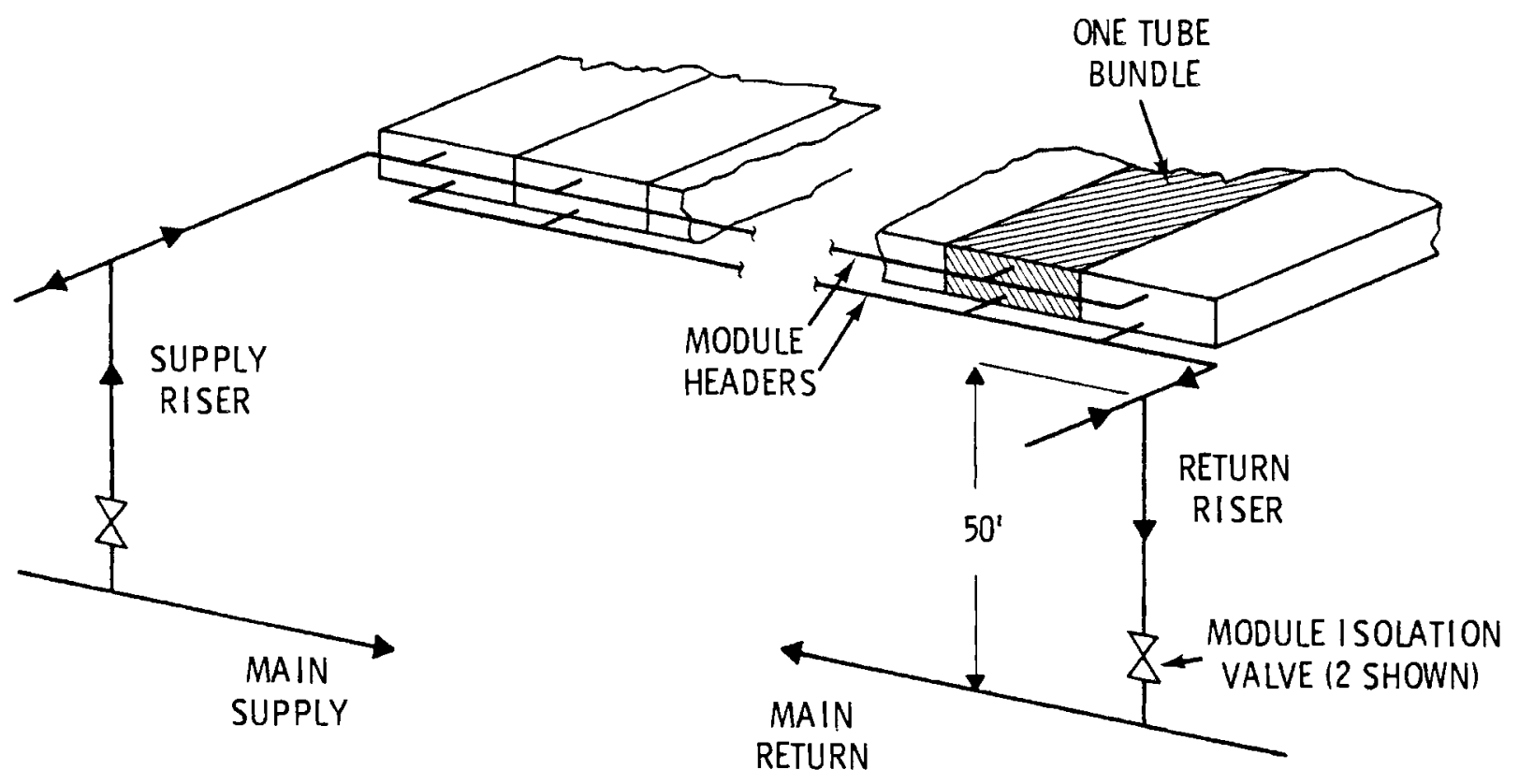

FIGURE 5-4. Module Piping Showing One of Two Opposed Banks of Tube Bundles

\subsubsection{Main Circulation Piping}

The main circulation piping for the rectilinear tower is similar to that for the circular towers. While the tees and reducers may be located differently according to the coolant distribution scheme, the systems for either tower arrangement consist of the same piping components. The comments of Section 5.1.1.1 apply here.

\subsection{PIPING SYSTEM COST ANALYSIS}

To arrive at a practical piping layout, cost estimates were made for several preliminary piping system designs. All the designs were developed on the same basis. The following list of conditions applies to the analysis in this section.

$$
\begin{array}{lr}
\text { Power plant size } & 1,000 \mathrm{MWe} \\
\text { Water flow rate } & 320,000 \mathrm{gpm} \\
\text { Water design velocity } & 7 \mathrm{ft} / \mathrm{sec} \\
\text { Heat exchanger length } & 3,456 \mathrm{ft} \\
\text { Distance from condenser to tower } & 500 \mathrm{ft}
\end{array}
$$


The nominal diameter of all piping system components was based upon the water flow rate and the water design velocity.

The designs developed for the above conditions were compared on the bas is of costs and upon the ability to incorporate the designs into a generalized computer model. The above conditions are specific only to the analysis presented in this section. The resulting computer model has the capability to design the piping according to almost any set of values of these parameters.

The purpose of this cost analys is was to compare different design possibilities and determine the extent to which the costs are a function of the design. The conclusions are that the costs are not greatly dependent upon the piping layout. Several reasonable configurations might be developed for the same design conditions that would be quite similar in cost. To visualize why this should be true, consider the input conditions required to establish the piping system design. With the power plant size fixed, these are:

- coolant flow rate

- heat exchanger width

- coolant design velocity

- system resolution

- distance from the condenser to the tower.

The piping system cost can be lowered by reducing either flow rate or heat exchanger width. In a water system, reducing the water flow rate will result in a higher temperature range for the water. This implies an increased heat exchanger ITD which would allow for a smaller heat exchanger. The result is that the system would operate with a higher turbine back pressure. Therefore, reducing the water flow will result in capital savings in the piping and heat exchanger but will increase the energy costs associated with operation at high back pressure.

To reduce the width of the heat exchanger, the number of tube rows in width could be reduced, shortening the length of the coolant circulation piping. This would result in a lower heat transfer area unless the tubes 
are made longer or the number of tube rows in the direction of air flow is increased. Reducing the heat exchanger area would require increasing the air velocity through the remainder of the heat exchanger to raise the heat transfer coefficient. Higher air velocities mean higher fan power costs. Tube length is limited by shipping considerations to about 80 feet. Increasing the tube rows in the direction of air flow also increases the fan power requirements.

Increasing the velocity of the coolant will reduce the required pipe diameter. Obviously, the smaller the pipe the lower the costs (for a given pipe design pressure). However, increasing the velocity results in increased pumping power requirements. Therefore, the tradeoff with design velocity is between pipe cost and pumping cost.

The system resolution is the percentage of the entire cooling system that can be isolated from the remainder of the cooling system with the use of valves. The system resolution has been established by industry practice to be between 40 and 80 MWe. To provide a cooling system for a 1000-MWe power station that allows control and isolation of much less than 40 MWe would result in increased costs. Resolution much above 80 MWe would not provide adequate cooling system control. The system resolution can be implicitly studied on a parametric basis by forcing the economics code to optimize at a given number of circular towers or by controlling the size of the modules of the rectilinear tower.

The distance from the condenser to the tower would in reality depend upon specific site conditions, such as air flow distribution and recirculation problems from nearby buildings. The pipe between the condenser and the tower is typically in excess of $\$ 1,000 / \mathrm{ft}$ each way for a 1000-MWe power station. Therefore, the requirements here should be fully considered. The distance of 500 feet was taken as a reasonable value for this study.

With the system resolution and the condenser-to-tower distance fixed, a piping system that will distribute a given amount of water at a given velocity to each of several hundred heat exchanger tube bundles must be provided. 
Regardless of coolant type (ammonia or water), costs will be substantial. Because of the differences in density, allowable design velocities and mass flow requirements, the ammonia pipe sizes are generally smaller than those for the water systems. However, much of the economic benefit is lost because the ammonia piping must be designed to about 450 psi as opposed to less than 125 psi for the water piping.

The possibility remaining for reducing the high capital cost of the piping system is to reduce the coolant flow rate, increase coolant design velocity, or decrease the heat exchanger width. The extent to which costs can be reduced depends upon the tradeoffs that result in the optimized design of the entire cooling system.

One area not yet investigated for potential cost savings is different pipe materials such as concrete or fiberglass reinforced plastic.

Cost estimates were obtained for the installed components of a steel piping system. $(18,19)$ These costs included material, shipping, installation, and contractor's overhead and profit. The components included the pipe, fittings and vaives in nominal diameters from 12 to 120 inches for water systems with a design pressure of $125 \mathrm{psi}$, and for ammonia systems with a design pressure of $350 \mathrm{psi}$. This cost data were extrapolated to include nominal diameters to 144 inches. Costs for 50 and 75-psi water systems and 450-psi ammonia systems were extrapolated from these data (see Appendix I). Similar cost data for reinforced plastic and prestressed concrete piping components have recently been generated for use in 50 and 100-psi water systems. $(20,21)$ Costs were also obtained for pumps with capacities from 10,000 to 150,000 gpm and total dynamic head from 120 to 200 feet of water. In reviewing the component costs with other sources, one observes that there are no exact costs; in some cases, costs may vary by a factor of two or more. The only way to determine the actual cost of building a large piping system would be to obtain bids with a detailed piping design. Even then, the costs would apply only to that design at the time of bidding. 


\subsubsection{Circular Towers}

The costs for various designs of each of the four subsystems of the circular tower piping model were determined. The most reasonable design from each group was then used in the generalized piping model.

The discussion in this section deals basically with the water system. The ammonia system differs from the water system design in two areas. One, the quadrant piping, is discussed in Section 5.1.1.2. The other difference is that the supply and return piping for the ammonia will be of different size because the densities and design velocities of the supply and return coolant are different. Otherwise, the configurations are the same. For this reason, the discussion of the ammonia system is brief.

\subsubsection{Pump Station}

The pump station design selected is shown in Figure 5-5. An estimate of the total component costs is given in Table $5-1$.

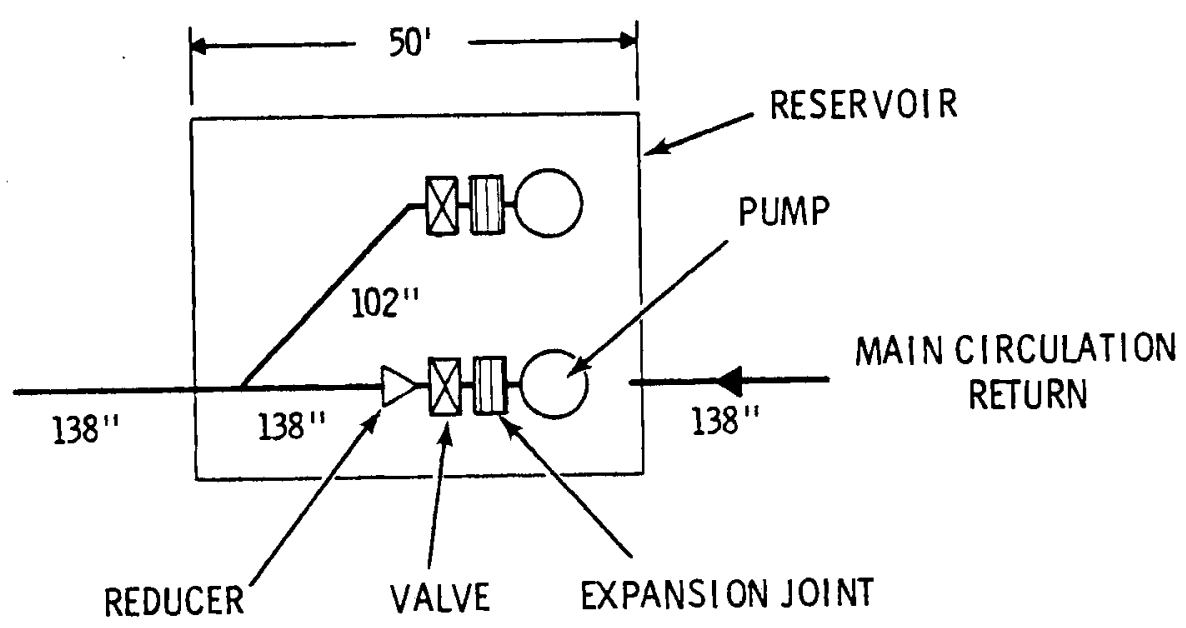

FIGURE $5-5$. Pump Station 
TABLE 5-1. Pump Station Cost Estimate

\begin{tabular}{|c|c|c|c|c|}
\hline Item & $\begin{array}{c}\text { Diameter, } \\
\text { in. }\end{array}$ & Length, $\mathrm{ft}$ & $\begin{array}{l}\text { Unit Cost, } \\
\$ / \mathrm{ft} \\
\end{array}$ & $\begin{array}{c}\text { Cost } \\
\$\end{array}$ \\
\hline Pipe & 102 & 10 & 990 & 9,900 \\
\hline Item & $\begin{array}{c}\text { Diameter, } \\
\text { in. } \\
\end{array}$ & Qty & $\begin{array}{l}\text { Unit Cost, } \\
\text { \$/each } \\
\end{array}$ & $\begin{array}{c}\text { Cost } \\
\$\end{array}$ \\
\hline Pumps & 320,000 & $\mathrm{gpm} 0 \$ 3 / \mathrm{gpm}$ & & 960,000 \\
\hline Exp. Joints & 102 & 2 & 26,900 & 53,800 \\
\hline Valves & 102 & 2 & 72,200 & 144,400 \\
\hline $45^{\circ}$ & 102 & 1 & 59,600 & 59,600 \\
\hline Wye & $138-102$ & 1 & 161,500 & 161,500 \\
\hline Reducer & $138-102$ & 1 & 188,000 & 188,000 \\
\hline
\end{tabular}

The two-pump configuration provides a pump capacity of 160,000 gpm each. The number of pumps affects the quantity and size of the fittings. However, because the pumps represent over 60 percent of the cost of the pump station, there is little potential for savings by varying either the number of pumps or the piping configuration. Therefore, only one design is shown here. It will be used throughout the analysis. In consideration of the purpose of this generalized piping model, no auxiliary pump capacity has been provided.

\subsubsection{Quadrant Piping}

Two schemes were considered for distributing the flow to the tube bundles. One has the supply and return to the middle of the quadrant. For the second design, the supply and return are at opposite ends of the quadrant. With respect to header design, the second would be identical to one having the supply and return at the same end of the quadrant. The two designs are shown in Figure 5-6. Cost estimates are given in Tables 5-2 and 5-3. 


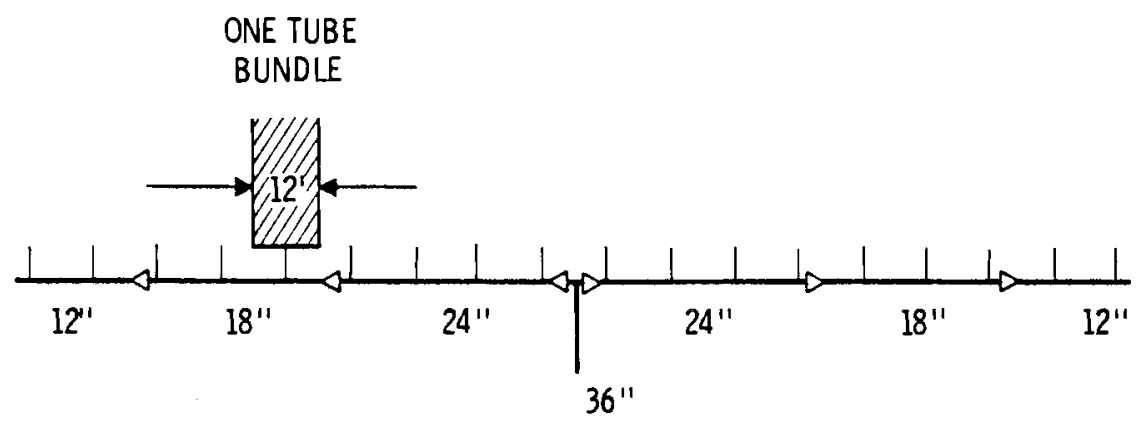

DESIGN Q1 - SUPPLY AND RETURN TO CENTER OF QUADRANT

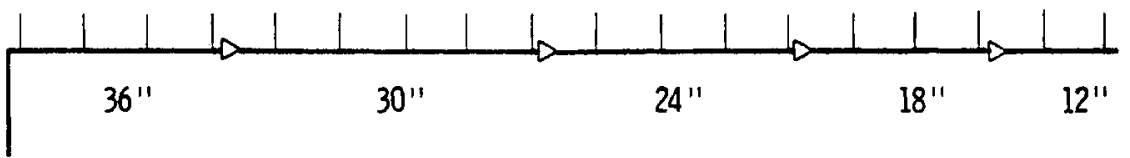

DESIGN Q2 - SUPPLY AND RETURN TO END OF QUADRANT

FIGURE 5-6. Quadrant Piping Designs Studied

This design shows 18 tube bundles, the result of using a bundle width of 12 feet. The width of the heat exchanger has been set at 3,456 feet. Therefore, 288 bundles are required. With the heat exchanger divided into four circular towers, there are 72 bundles per tower or 18 bundles per quadrant.

The second design (supply and return at end of quadrant) was chosen for the piping model aithough the costs are about 8 percent higher. This decision was made somewhat arbitrarily. Selection of the header design in an actual installation would be determined by flow distribution as well as cost considerations. Problems related to maldistribution of flow have not been considered in this analysis.

For the only large all dry-cooled power plant being built in the U.S., and circular towers with diameters of 210 feet were offered. This is a 330-MWe fossil-fueled power station. With this as an indicator, one might expect the design for a 1000-MWe plant to require four to eight towers of comparable size. 
TABLE 5-2. Quadrant Header Design Q1 Cost Estimate

\begin{tabular}{|c|c|c|c|c|}
\hline Item & $\begin{array}{c}\text { Diameter, } \\
\text { in. } \\
\end{array}$ & $\begin{array}{c}\text { Length, } \\
\mathrm{ft} \\
\end{array}$ & $\begin{array}{l}\text { Unit Cost, } \\
\$ / \mathrm{ft} \\
\end{array}$ & $\operatorname{Cos} t, \$$ \\
\hline \multirow[t]{3}{*}{ Pipe } & 24 & 56 & 125 & 7,000 \\
\hline & 18 & 50 & 100 & 5,000 \\
\hline & 12 & 36 & 75 & 2,700 \\
\hline I tem & $\begin{array}{c}\text { Diameter } \\
\text { in. }\end{array}$ & Qty & $\begin{array}{c}\text { Unit Cost, } \\
\text { \$/each } \\
\end{array}$ & $\operatorname{Cos} t, \$$ \\
\hline \multirow[t]{4}{*}{ Tees } & $36-36$ & 1 & 4500 & 4,500 \\
\hline & $24-8$ & 8 & 2400 & 19,200 \\
\hline & $18-8$ & 6 & 1600 & 9,600 \\
\hline & $12-8$ & 4 & 1100 & 4,400 \\
\hline \multirow[t]{3}{*}{ Reducers } & $36-24$ & 2 & 1600 & 3,200 \\
\hline & $24-18$ & 2 & 900 & 1,800 \\
\hline & $18-12$ & 2 & 800 & 1,600 \\
\hline
\end{tabular}

Bundle

Fittings

\begin{tabular}{llr}
18 & 1750 & 31,500 \\
\cline { 2 - 3 } Cost/Header & $\$ 90,500$ \\
Cost/Quadrant & $\$ 181,000$ \\
Cost/Tower & $\$ 724,000$ \\
Tota1 Cost (4 Towers) & $\$ 2,896,000$
\end{tabular}

Accordingly, a cost estimate was prepared for the quadrant piping with an eight-tower configuration. In this case, there would be nine bundles per quadrant. With the supply and return at the ends of the quadrants, the total cost of the quadrant piping would be $\$ 2,788,000$

The water and ammonia systems use the same quadrant headering model except that the vapor supply line is routed to the top of the quadrant for the ammonia systems. The only additional cost is from the length of pipe for the vapor supply line. 
TABLE 5-3. Quadrant Header Design Q2 Cost Estimate

\begin{tabular}{|c|c|c|c|c|}
\hline I tem & $\begin{array}{c}\text { Di ame ter, } \\
\quad \text { in. } \\
\end{array}$ & $\begin{array}{l}\text { Length, } \\
\mathrm{ft}\end{array}$ & $\begin{array}{c}\text { Unit Cost, } \\
\$ / \mathrm{ft} \\
\end{array}$ & Cost, $\$$ \\
\hline \multirow[t]{5}{*}{ Pipe } & 36 & 18 & 175 & 3,200 \\
\hline & 30 & 35 & 150 & 5,200 \\
\hline & 24 & 28 & 125 & 3,500 \\
\hline & 18 & 25 & 100 & 2,500 \\
\hline & 12 & 18 & 75 & 1,400 \\
\hline
\end{tabular}

\begin{tabular}{|c|c|c|c|c|}
\hline Item & $\begin{array}{c}\text { Diameter, } \\
\text { in. } \\
\end{array}$ & Qty & $\begin{array}{l}\text { Unit Cost, } \\
\$ / \text { each } \\
\end{array}$ & $\operatorname{Cos} t, \$$ \\
\hline \multirow[t]{5}{*}{ Tees } & $36-8$ & 4 & 3200 & 12,800 \\
\hline & $30-8$ & 5 & 2800 & 14,000 \\
\hline & $24-8$ & 4 & 2400 & 9,600 \\
\hline & $18-8$ & 3 & 1600 & 4,800 \\
\hline & $12-8$ & 2 & 1100 & 2,200 \\
\hline \multirow[t]{4}{*}{ Reducers } & $36-30$ & 1 & 1600 & 1,600 \\
\hline & $30-24$ & 1 & 1300 & 1,300 \\
\hline & $24-18$ & 1 & 900 & 900 \\
\hline & $18-12$ & 1 & 800 & 800 \\
\hline $90^{\circ}$ Elbow & 36 & 1 & 3600 & 3,600 \\
\hline \multirow[t]{5}{*}{$\begin{array}{l}\text { Bundle } \\
\text { Fittings }\end{array}$} & & 18 & 1750 & 31,500 \\
\hline & & \multicolumn{2}{|c|}{ Cost/Header } & 98,900 \\
\hline & & \multicolumn{2}{|c|}{ Cost/Quadrant } & $\$ 197,700$ \\
\hline & & \multicolumn{2}{|c|}{ Cost/Tower } & $\$ 790,800$ \\
\hline & & \multicolumn{2}{|c|}{ Total Cost (4 Towers) } & $\$ 3,163,000$ \\
\hline
\end{tabular}




\subsubsection{Tower Distribution Piping}

The two most cost effective of the many configurations studied for the tower distribution piping are shown in Figure 5-7. In both designs the supply and return piping are assumed to be the same. Cost estimates are given in Tables 5-4 and 5-5.

\section{DESIGN T1}

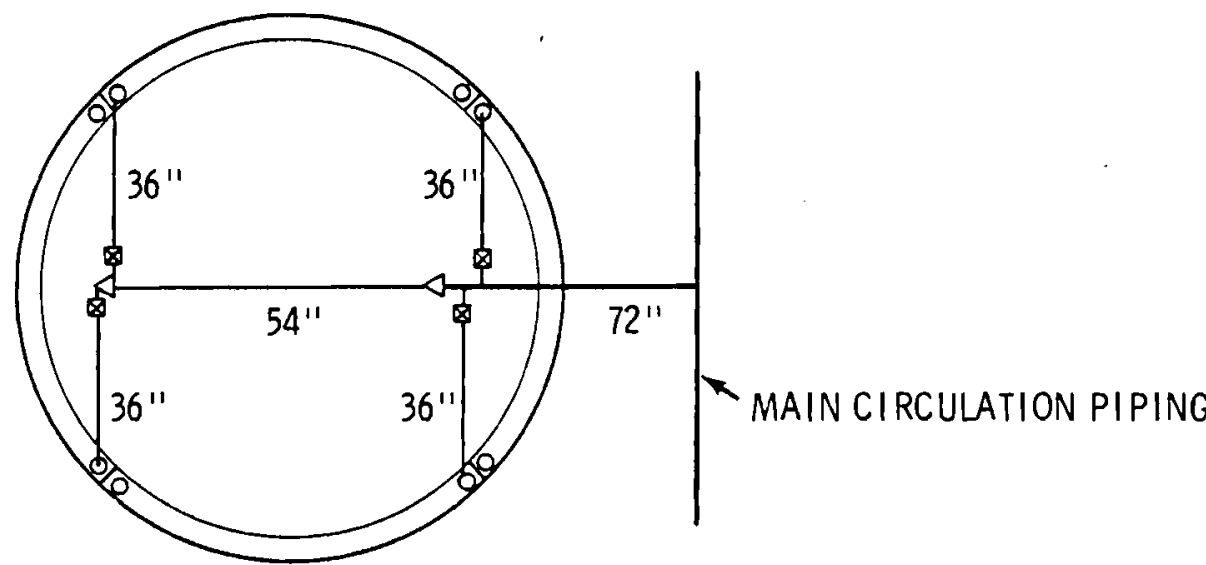

$$
\mid-100^{\prime} \rightarrow
$$

TOWER DIAMETER $=275^{\prime}$

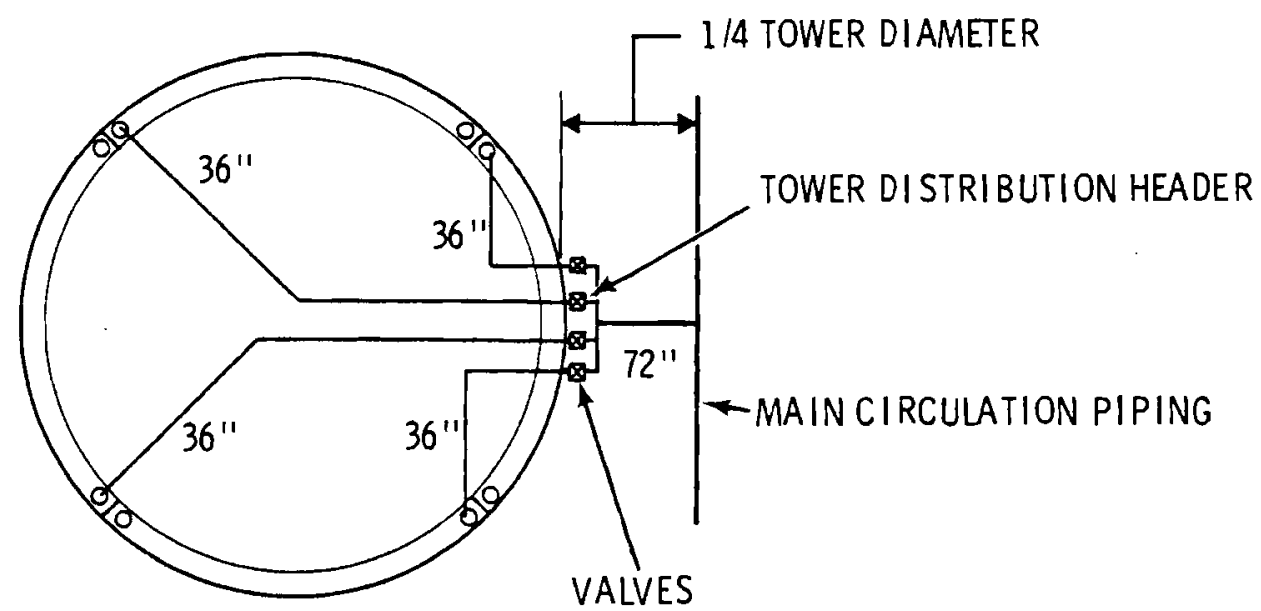

DESIGN T2

FIGURE 5-7. Tower Distribution Piping Designs Studied 
TABLE 5-4. Tower Distribution Piping Design Tl Cost Estimate

\begin{tabular}{|c|c|c|c|c|}
\hline I tem & $\begin{array}{c}\text { Diameter, } \\
\text { in. } \\
\end{array}$ & $\begin{array}{c}\text { Length, } \\
\mathrm{ft} \\
\end{array}$ & $\begin{array}{l}\text { Unit } \cos t, \\
\$ / \mathrm{ft} \\
\end{array}$ & $\cos t, \$$ \\
\hline \multirow[t]{3}{*}{ Pipe } & 72 & 120 & 665 & 79,800 \\
\hline & 54 & 185 & 465 & 86,000 \\
\hline & 36 & 400 & 260 & 104,000 \\
\hline I tem & $\begin{array}{c}\text { Diameter, } \\
\text { in. } \\
\end{array}$ & Qty & $\begin{array}{l}\text { Unit Cost, } \\
\text { \$/each } \\
\end{array}$ & $\cos t, \$$ \\
\hline \multirow[t]{2}{*}{ Tees } & $72-36$ & 2 & 26,500 & 53,000 \\
\hline & $54-36$ & 1 & 12,300 & 12,300 \\
\hline \multirow[t]{2}{*}{ Reducers } & $72-54$ & 1 & 9,500 & 9,500 \\
\hline & $54-36$ & 1 & 5,200 & 5,200 \\
\hline $90^{\circ}$ Elbow & 36 & 5 & 3,600 & 18,000 \\
\hline Valves & 36 & 4 & 14,100 & 56,400 \\
\hline \multirow[t]{4}{*}{ Flanges } & 36 & 8 & 1,400 & 11,200 \\
\hline & & & & $\$ 435,400$ \\
\hline & & \multicolumn{2}{|c|}{ Cost/Tower (Supply \& Return) } & $\$ 870,800$ \\
\hline & & \multicolumn{2}{|c|}{ Total Cost (4 Towers) } & $\$ 3,483,000$ \\
\hline
\end{tabular}

The spacing needed between the circular towers requires further investigation. If the towers are too close, air flow recirculation and maldistribution may be a problem. Too much space between towers increases the piping costs and the pumping power requirements. Some work has been done at PNL dealing with this air distribution problem for large dry-cooled power plants. (22)

For this study, it was decided to provide $3 / 2$ tower diameters between tower centers. In view of the 1 ack of established practice, this was considered to be a reasonable value. The main circulation piping is routed between towers to leave one-fourth of a tower diameter between the main circulation piping and the edge of the tower.

Design $T 2$ was chosen for the generalized model although it is about 15 percent more costly than Design $T 1$. The benefits of locating the control valves at a common point outside the tower could outweigh the cost difference. 
TABLE 5-5. Tower Distribution Piping Design T2 Cost Estimate

\begin{tabular}{|c|c|c|c|c|}
\hline I tem & $\begin{array}{c}\text { Di ame ter, } \\
\text { in. }\end{array}$ & $\begin{array}{l}\text { Length, } \\
\mathrm{ft}\end{array}$ & $\begin{array}{l}\text { Unit cost, } \\
\$ / \mathrm{ft}\end{array}$ & Cost, $\$$ \\
\hline \multirow{2}{*}{ Pipe } & 72 & 45 & 665 & 29,900 \\
\hline & 36 & 945 & 260 & 245,70 \\
\hline
\end{tabular}

\begin{tabular}{|c|c|c|c|c|}
\hline Item & $\begin{array}{c}\text { Diameter, } \\
\text { in. }\end{array}$ & Qty & $\begin{array}{l}\text { Unit Cost, } \\
\text { \$/each } \\
\end{array}$ & $\cos t, \$$ \\
\hline \multirow[t]{2}{*}{ Tees } & $72-72$ & 1 & 37,000 & 37,000 \\
\hline & $72-36$ & 4 & 26,500 & 106,000 \\
\hline $45^{\circ}$ Elbow & 36 & 2 & 2,500 & 5,000 \\
\hline $90^{\circ}$ Elbow & 36 & 6 & 3,600 & 21,600 \\
\hline Valves & 36 & 4 & 14,100 & 56,400 \\
\hline \multirow[t]{4}{*}{ Flanges } & 36 & 8 & 1,400 & 11,200 \\
\hline & & & & $\$ 512,800$ \\
\hline & & \multicolumn{2}{|c|}{ Cost/Tower (Supply \& Return) } & $\$ 1,026,000$ \\
\hline & & \multicolumn{2}{|c|}{ Total Cost (4 Towers) } & $\$ 4,104,000$ \\
\hline
\end{tabular}

This would be especially true if a drain and refill system were required for the cooling system. Also, accessibility and maintenance of the valves would be simplified with Design T2. For these reasons, it is believed that Design $T 2$ is more representative of what industry would actually offer.

A cost estimate was also prepared for the tower distribution piping according to Design $\mathrm{T} 2$ for an eight-tower arrangement. The total cost was $\$ 3,075,000$.

\subsubsection{Main Circulation Piping}

The number of towers and the tower arrangement are important parameters for the main circulation piping. The distance from the condenser should also be considered important in the same light as the tower spacing, discussed in Section 5.2.1.3. The costs resulting from maldistribution of 
air flow due to the interaction of the power plant building and the cooling tower would have to be traded off with the costs required to increase the distance between the two structures. Two arrangements with four towers and one arrangement with eight towers were prepared for the design conditions given in Section 5.1. These arrangements are shown in Figures 5-8 through 5-10. Cost estimates for these designs are given in Tables 5-6 through 5-8. The total costs are not twice the cost of supply because 50 feet of 138 -inch diameter pipe is deducted for the pump station in the return piping. This applies to all three systems.

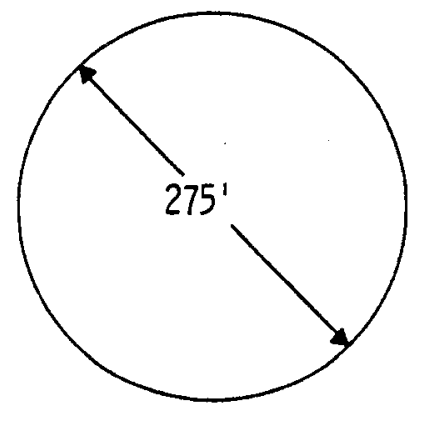

LIMITS OF MAIN CIRCULATION PIPING

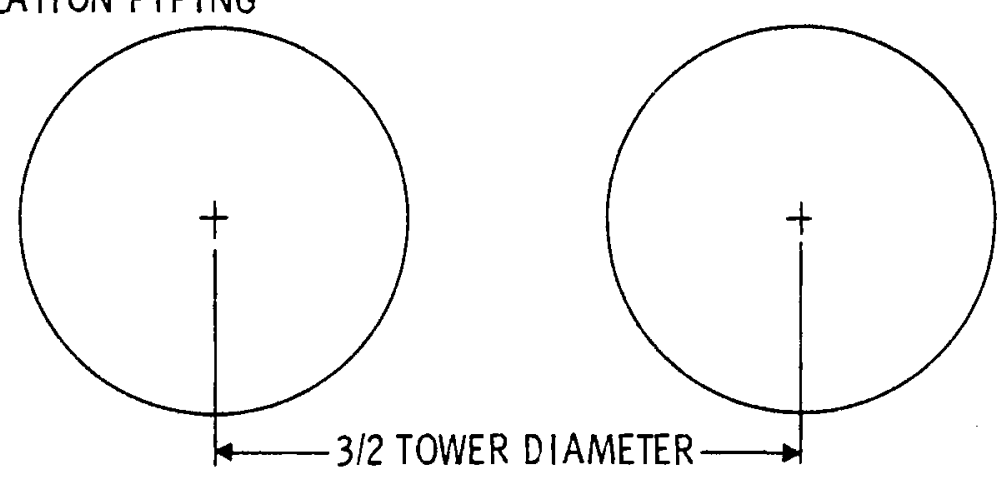

FIGURE 5-8. Main Circulation Piping Design C1 


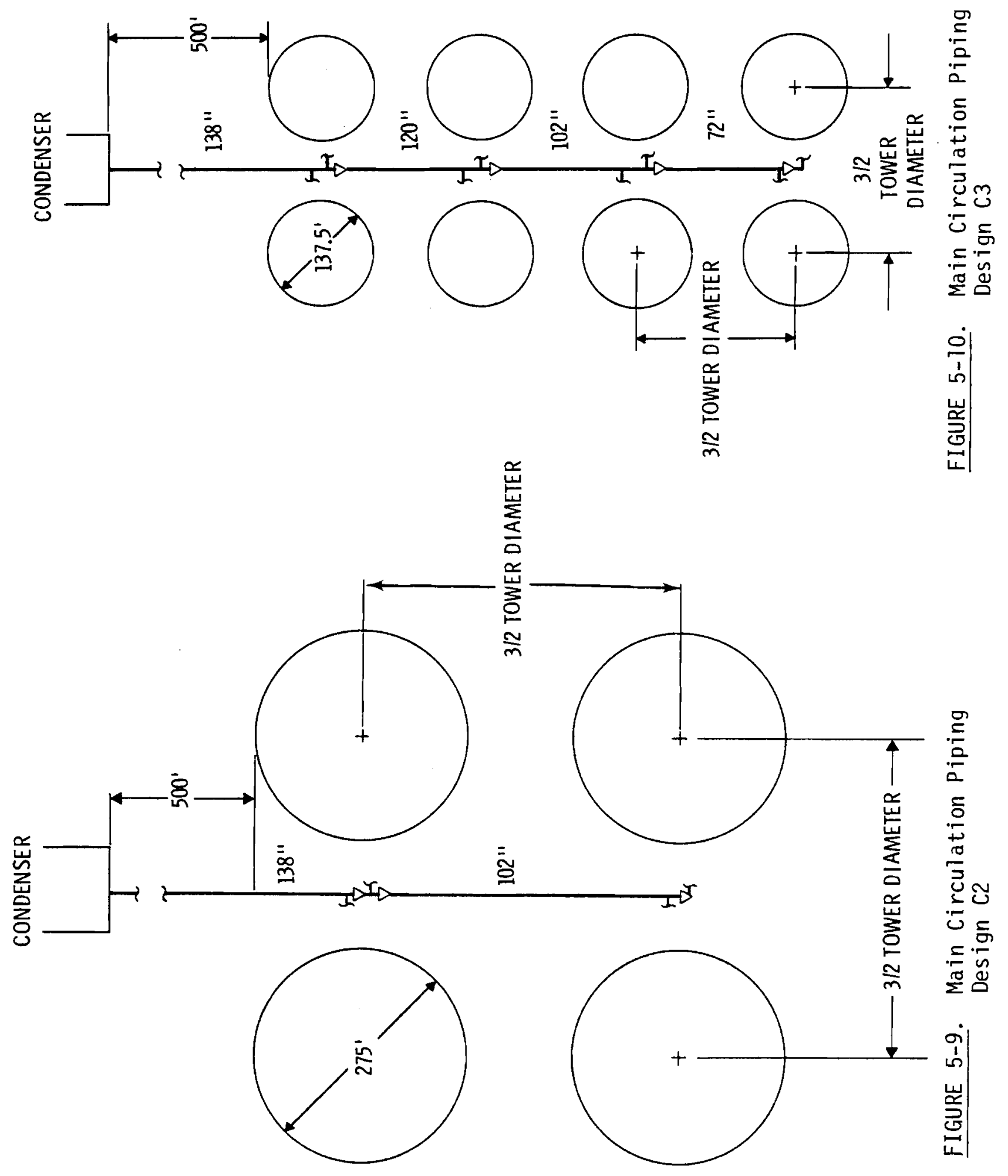


TABLE 5-6. Main Circulation Piping Design Cl Cost Estimate

\begin{tabular}{|c|c|c|c|c|}
\hline Item & $\begin{array}{c}\text { Diameter, } \\
\text { in. }\end{array}$ & $\begin{array}{l}\text { Length, } \\
\mathrm{ft}\end{array}$ & $\begin{array}{l}\text { Unit Cost, } \\
\$ / \mathrm{ft} \\
\end{array}$ & $\operatorname{Cos} t, \$$ \\
\hline \multirow[t]{2}{*}{ Pipe } & 138 & 637.5 & 1,535 & 978,600 \\
\hline & 72 & 825 & 665 & 548,600 \\
\hline Item & $\begin{array}{c}\text { Di ameter, } \\
\text { in. } \\
\end{array}$ & Qty & $\begin{array}{l}\text { Unit Cost, } \\
\$ / \text { each }\end{array}$ & Cost, $\$$ \\
\hline \multirow[t]{3}{*}{$\begin{array}{l}\text { Distribution } \\
\text { Box }\end{array}$} & & 1 & 250,000 & 250,000 \\
\hline & \multicolumn{3}{|c|}{ Cost of Supply } & $\$ 1,777,000$ \\
\hline & & \multicolumn{2}{|c|}{ Total Cost (Supply \& Return) } & $\$ 3,478,000$ \\
\hline
\end{tabular}

TABLE 5-7. Main Circulation Piping Design C2 Cost Estimate

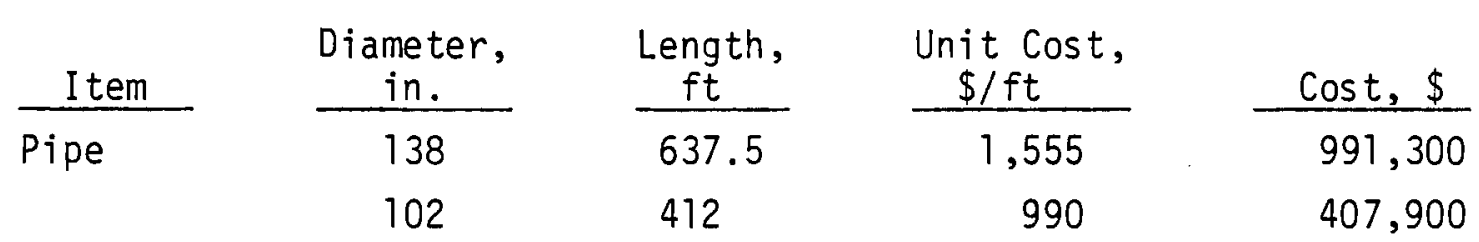

\begin{tabular}{|c|c|c|c|c|}
\hline Item & $\begin{array}{c}\text { Diameter, } \\
\text { in. }\end{array}$ & Qty & $\begin{array}{l}\text { Unit Cost, } \\
\text { \$/ each } \\
\end{array}$ & Cost, $\$$ \\
\hline \multirow[t]{3}{*}{ Tees } & $138-72$ & 1 & 126,200 & 126,200 \\
\hline & $120-72$ & 1 & 100,200 & 100,200 \\
\hline & $102-72$ & 1 & 59,900 & 59,900 \\
\hline \multirow[t]{3}{*}{ Reducers } & $138-120$ & 1 & 115,000 & 115,000 \\
\hline & $120-102$ & 1 & 73,000 & 73,000 \\
\hline & $102-72$ & 1 & 32,800 & 32,800 \\
\hline \multirow[t]{3}{*}{$90^{\circ}$ ETbow } & 72 & 1 & 36,400 & 36,400 \\
\hline & \multicolumn{3}{|c|}{ Cost of Supply } & $\$ 1,943,000$ \\
\hline & \multicolumn{3}{|c|}{ Total Cost (Supply \& Return) } & $\$ 3,808,000$ \\
\hline
\end{tabular}


TABLE 5-8. Main Circulation Piping Design C3 Cost Estimate

\begin{tabular}{|c|c|c|c|c|}
\hline I tem & $\begin{array}{c}\text { Diameter, } \\
\text { in. }\end{array}$ & $\begin{array}{c}\text { Length, } \\
\mathrm{ft} \\
\end{array}$ & $\begin{array}{l}\text { Unit Cost, } \\
\$ / \mathrm{ft} \\
\end{array}$ & $\operatorname{Cos} t, \$$ \\
\hline \multirow[t]{4}{*}{ Pipe } & 138 & 569 & 1,555 & 884,800 \\
\hline & 120 & 206 & 1,390 & 286,300 \\
\hline & 102 & 206 & 990 & 203,900 \\
\hline & 72 & 206 & 665 & 137,000 \\
\hline Item & $\begin{array}{c}\text { Di ame ter, } \\
\quad \text { in. }\end{array}$ & Qty & $\begin{array}{l}\text { Unit Cost, } \\
\text { \$/ each } \\
\end{array}$ & Cost, $\$$ \\
\hline \multirow[t]{4}{*}{ Tees } & $138-48$ & 2 & 117,200 & 234,400 \\
\hline & $120-48$ & 2 & 91,100 & 182,200 \\
\hline & $102-48$ & 2 & 50,900 & 101,800 \\
\hline & $72-48$ & 1 & 28,100 & 28,100 \\
\hline \multirow[t]{4}{*}{ Reducers } & $138-120$ & 1 & 114,000 & 114,000 \\
\hline & $120-102$ & 1 & 73,000 & 73,000 \\
\hline & $102-72$ & 1 & 32,800 & 32,800 \\
\hline & $72-48$ & 1 & 15,000 & 15,000 \\
\hline \multirow[t]{3}{*}{$90^{\circ}$ Elbow } & 48 & 1 & 8,000 & 8,000 \\
\hline & \multicolumn{3}{|c|}{ Cost of Supply } & $\$ 2,301,000$ \\
\hline & & \multicolumn{2}{|c|}{ Total Cost (Supply \& Return) } & $\$ 4,525,000$ \\
\hline
\end{tabular}

The configuration of Designs 2 and 3 was used in the generalized piping model even though Design 2 is about 10 percent more costly than Design 1 . The tower configuration of Designs 2 and 3 is more readily adaptable to computer modeling. For example, what would be done to Design 1 if the optimization scheme required a cooling system having tweive towers? The distribution box shown in Design 1 would likely be less expensive than all the tees required in the other designs. However, it is extremely difficult to estimate the price of this item on a generalized plan. Because prices for tees were available, the use of Design 2 in the generalized model was further enhanced. 


\subsubsection{Capital Cost Comparisons}

The capital costs of three piping system designs are compared in Table 5-9.

The difference in costs between Designs $\mathrm{C} 1$ and $\mathrm{C} 2$ is about 10 percent. The subsystems used in Design $C 2$ were adapted to the generalized piping model although the costs are slightly higher. This was done in consideration of industry practice and ease of computer modeling. The cost comparison indicates that a decision to use either design would not have a large influence on the design and comparison of optimized cooling systems.

Also observable from the cost comparisons is the fact that costs are not overly sensitive to the number of towers, at least between the range of four to eight towers. This range includes the number and size of towers that would likely be offered by industry for the given design conditions.

TABLE 5-9. Capital Cost Comparison of Three Piping System Designs for Circular Towers

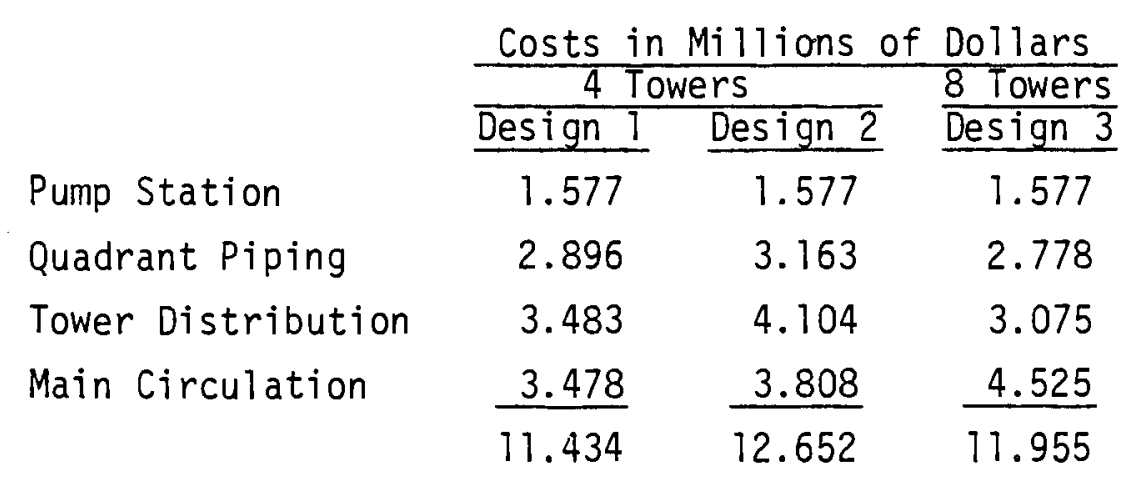

\subsubsection{Rectilinear Towers}

A rectilinear piping model was developed for the water system only. This includes both plastic tube and metal finned tube heat exchangers. There is no difference between the piping design models for either application.

A cost analysis was made on the subsystems of the rectilinear tower piping in a manner similar to the analysis of the circular tower piping. The same design conditions were used. The analysis led to the development of a generalized computer model of the rectilinear piping system. 
Many features of the rectilinear and circular tower piping models are identical. This was done wherever possible to facilitate comparison of the two configurations.

\subsubsection{Pump Station}

The pump station used in the rectilinear model is exactly that developed in Section 5.1.1.1 for circular towers.

\subsubsection{Module Piping}

To be consistent with the quadrant piping model, the supply and return points of the module headers were located at opposite ends of the module. This somewhat limits the headering arrangements that can be considered.

In considering the most economic number of tube bundles per module, two cases were evaluated. The design conditions require 288 tube bundles. One design has 12 modules with 24 bundles each. In this design, 8 percent of the cooling system can be isolated. The second design has 24 modules with 12 tube bundles each, a resolution of about 4 percent of the cooling system. These module piping designs are shown in Figure 5-11. Cost of estimates are given in Tables 5-10 and 5-11. It is evident that the cost of module piping is essentially independent of the number of bundles per module so long as the cooling system resolution is on the order of 4 to 8 percent. This range is within industry practice for a 1000-MWe power plant.

\subsubsection{Main Circulation Piping}

Several configurations were considered for distribution of the coolant to the modules. The general conclusion of these cost studies was that logical rearrangements of the main circulation piping to seek an optimum cost resulted in only minor cost differences.

The two-pass heat exchanger model allows locating the main circulation supply and return piping between the opposed banks of tube bundles composing the modules. This is believed to provide the most economic use of the main circulation piping. The cost of the circulation piping was determined for a one-pass heat exchanger model and found to be slightly more expensive than 
DESIGN M1 - 24 BUNOLES /MODULE
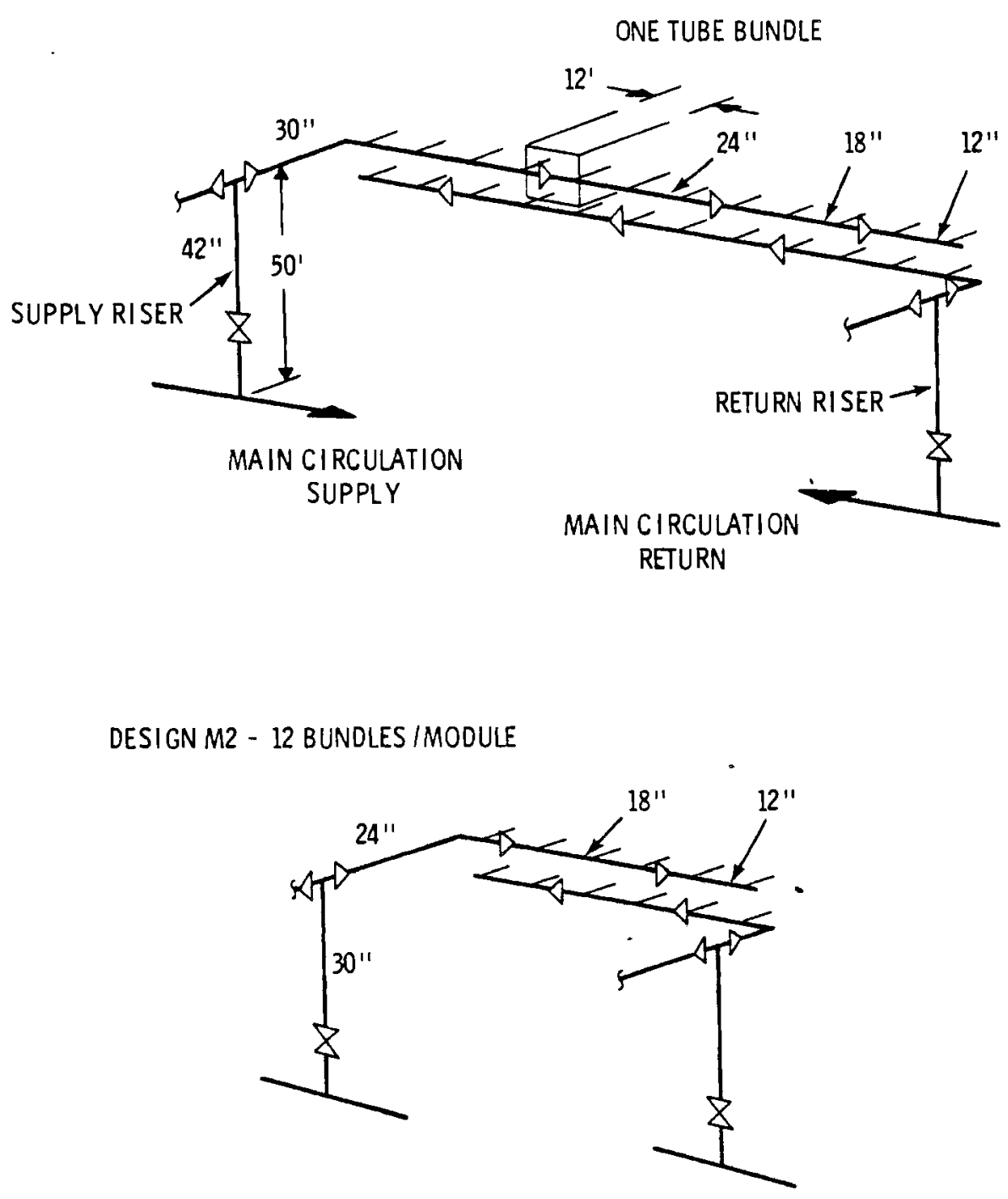

FIGURE 5-11. Module Piping Designs Studied

for a two-pass model. For the one-pass model, the circulation supply was located between opposed banks of tube bund?es. However, two parallel return lines were required, one line along each side of the tower. Although the pipe is smaller in each return line, the total cost was greater. In terms of cost per unit of cross sectional flow area, larger pipe is less expensive. As a result, parallel pipe runs should be avoided. 
TABLE 5-10. Module Piping Design M1 Cost Estimate

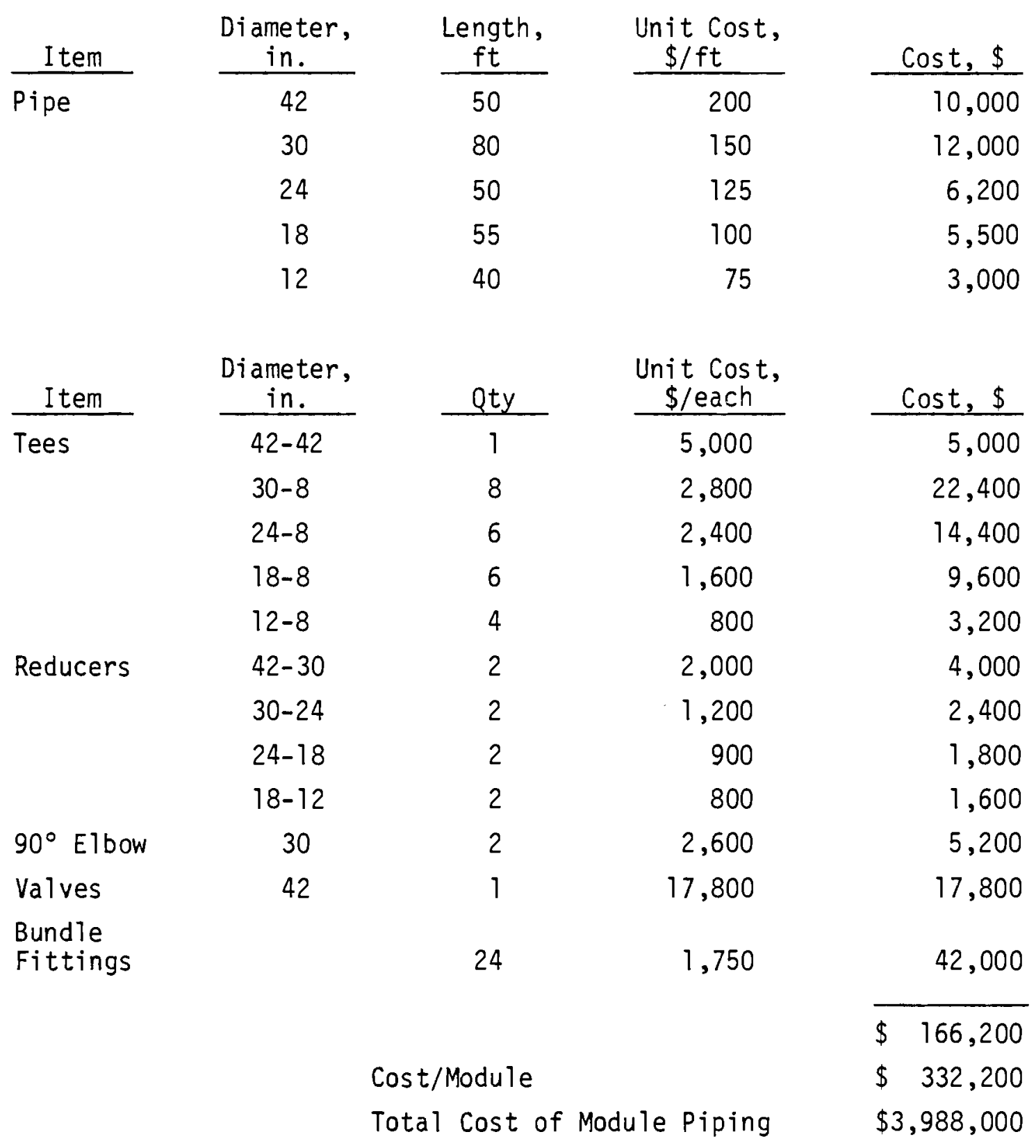


TABLE 5-11. Module Piping Design M2 Cost Estimate

\begin{tabular}{|c|c|c|c|c|}
\hline I tem & $\begin{array}{c}\text { Diameter, } \\
\text { in. }\end{array}$ & $\begin{array}{l}\text { Length, } \\
\mathrm{ft}\end{array}$ & $\begin{array}{l}\text { Unit Cost, } \\
\$ / \mathrm{ft}\end{array}$ & Cost, $\$$ \\
\hline \multirow[t]{4}{*}{ Pipe } & 30 & 50 & 150 & 7,500 \\
\hline & 24 & 40 & 125 & 5,000 \\
\hline & 18 & 55 & 100 & 5,500 \\
\hline & 12 & 40 & 75 & 3,000 \\
\hline
\end{tabular}

\begin{tabular}{|c|c|c|c|c|}
\hline Item & $\begin{array}{c}\text { Diameter, } \\
\text { in. }\end{array}$ & Qty & $\begin{array}{c}\text { Unit Cost, } \\
\$ / \text { each }\end{array}$ & $\operatorname{Cos} t, \$$ \\
\hline \multirow[t]{4}{*}{ Tees } & $30-30$ & 1 & 3,800 & 3,800 \\
\hline & $24-8$ & 2 & 2,400 & 4,800 \\
\hline & $18-8$ & 6 & 1,600 & 9,600 \\
\hline & $12-8$ & 4 & 800 & 3,200 \\
\hline \multirow[t]{3}{*}{ Reducers } & $30-24$ & 2 & 1,200 & 2,400 \\
\hline & $24-18$ & 2 & 900 & 1,800 \\
\hline & $18-12$ & 2 & 800 & 1,600 \\
\hline $90^{\circ}$ Elbow & 24 & 2 & 2,000 & 4,000 \\
\hline Valve & 30 & 1 & 11,200 & 11,200 \\
\hline \multirow[t]{4}{*}{$\begin{array}{l}\text { Bundle } \\
\text { Fittings }\end{array}$} & & 12 & 1,750 & 21,000 \\
\hline & & & & 84,400 \\
\hline & \multicolumn{3}{|c|}{ Cost/Module } & $\$ 168,800$ \\
\hline & & \multicolumn{2}{|c|}{ Total Cost of Module Piping } & $\$ 4,051,000$ \\
\hline
\end{tabular}

The configurations shown in Figure 5-12 were used in the piping model to evaluate the effect of cooling system resolution on the cost of the main circulation piping. The cost estimates for the designs are presented in Tables 5-12 and 5-13. Because the module return riser is at the opposite end of the module from the supply riser, the main circulation return header is extended to the end of the tower. The result is that total costs are more than twice the cost of the supply piping. 


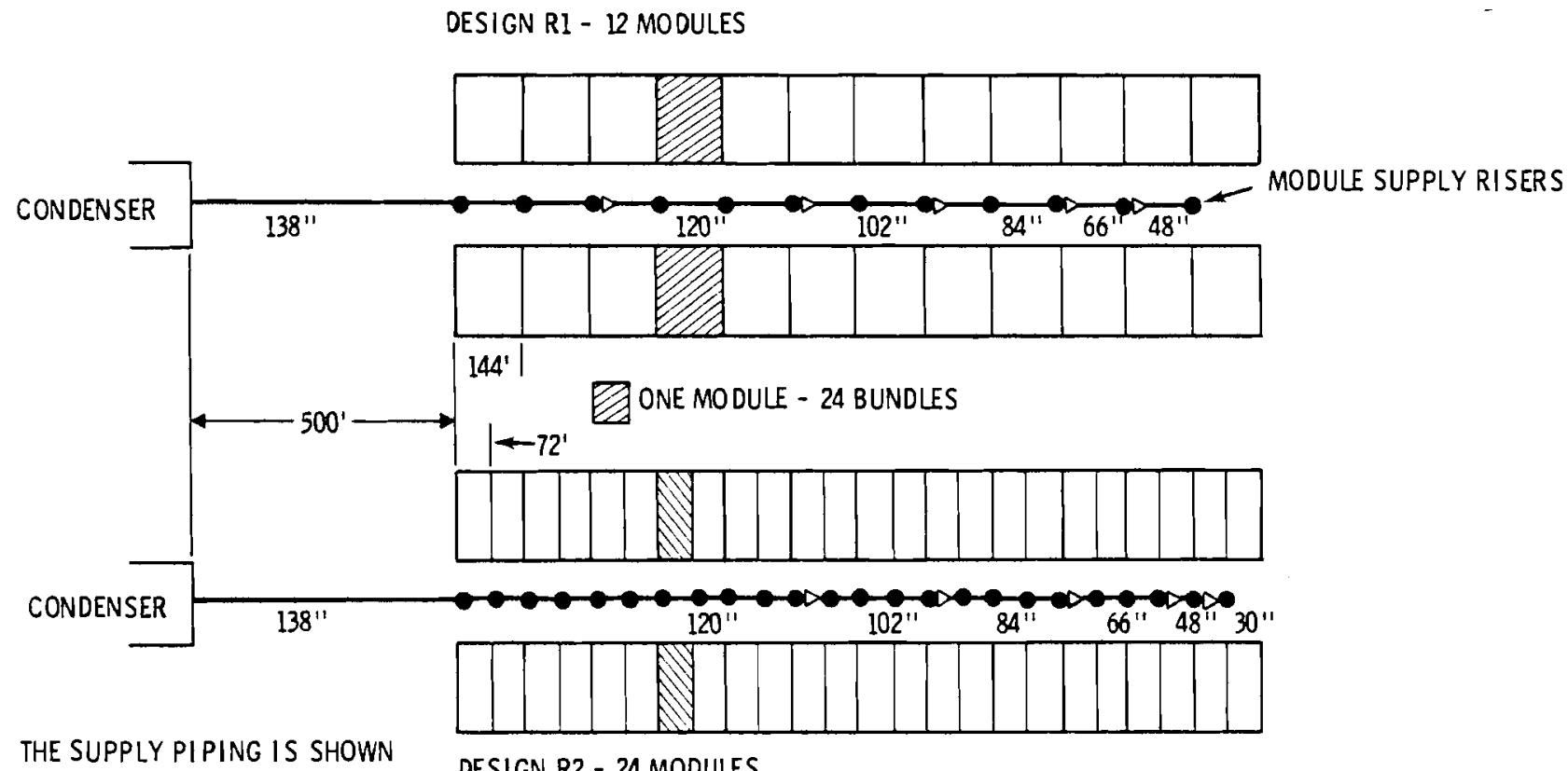

FOR BOTH DESIGNS DESIGN R2 - 24 MODULES

ONE MODULE - 12 BUNDLES

FIGURE 5-12. Rectilinear Tower Main Circulation Piping Designs R1 and R2

The tabulated costs show that increased cooling system resolution results in increased cost with respect to the main circulation piping. This was not true for the module piping.

Another configuration for the main circulation piping is shown in Figure 5-13. A cost estimate is given in Table 5-14. This is similar to the quadrant headering where the supply and return are to the center of the header. The cost improvements are also similar. Although this design is less expensive, it was not used in the generalized piping model. This configuration would not coincide with the design of the main circulation header for circular towers. It would have been more difficult to deal with an odd number of modules.

\subsubsection{Capital Cost Comparisons}

The capital costs of the rectilinear piping model are compared in Table 5-15. Design Rl was used to develop the generalized piping model. 
TABLE 5-12. Main Circulation Piping Design RT Cost Estimate

\begin{tabular}{|c|c|c|c|c|}
\hline I tem & $\begin{array}{c}\text { Diameter, } \\
\text { in. } \\
\end{array}$ & $\begin{array}{l}\text { Length, } \\
\mathrm{ft}\end{array}$ & $\begin{array}{l}\text { Unit Cost, } \\
\$ / \mathrm{ft}\end{array}$ & $\operatorname{Cos} t, \$$ \\
\hline \multirow[t]{6}{*}{ Pipe } & 138 & 745 & 1,555 & $1,158,500$ \\
\hline & 120 & 395 & 1,390 & 549,100 \\
\hline & 102 & 265 & 990 & 262,300 \\
\hline & 84 & 270 & 750 & 202,500 \\
\hline & 66 & 135 & 555 & 74,900 \\
\hline & 48 & 140 & 420 & 58,800 \\
\hline
\end{tabular}

\begin{tabular}{|c|c|c|c|c|}
\hline Item & $\begin{array}{c}\text { Diameter, } \\
\text { in. } \\
\end{array}$ & Qty & $\begin{array}{l}\text { Unit Cost, } \\
\text { \$/each } \\
\end{array}$ & Cost, $\$$ \\
\hline \multirow[t]{6}{*}{ Tees } & $138-42$ & 3 & 116,300 & 348,900 \\
\hline & $120-42$ & 3 & 89,500 & 268,500 \\
\hline & $102-42$ & 2 & 49,300 & 98,600 \\
\hline & $84-42$ & 2 & 33,100 & 66,200 \\
\hline & $66-42$ & 1 & 21,000 & 21,000 \\
\hline & $48-42$ & 1 & 8,300 & 8,300 \\
\hline \multirow[t]{7}{*}{ Reducers } & $138-120$ & 1 & 115,000 & 115,000 \\
\hline & $120-102$ & 1 & 73,000 & 73,000 \\
\hline & $102-84$ & 1 & 19,300 & 19,300 \\
\hline & $84-66$ & 1 & 13,500 & 13,500 \\
\hline & $66-48$ & 1 & 7,100 & 7,100 \\
\hline & & & & $\$ 3,345,000$ \\
\hline & & \multicolumn{2}{|c|}{ Total Cost (Supply \& Return) } & $\$ 6,837,000$ \\
\hline
\end{tabular}


TABLE 5-13. Main Circulation Piping Design R2 Cost Estimate

\begin{tabular}{|c|c|c|c|c|}
\hline Item & $\begin{array}{c}\text { Diameter, } \\
\text { in. }\end{array}$ & $\begin{array}{c}\text { Length, } \\
\mathrm{ft} \\
\end{array}$ & $\begin{array}{l}\text { Unit Cost, } \\
\$ / \mathrm{ft} \\
\end{array}$ & Cost, $\$$ \\
\hline \multirow[t]{7}{*}{ Pipe } & 138 & 775 & 1,555 & $1,205,100$ \\
\hline & 120 & 300 & 1,390 & 417,000 \\
\hline & 102 & 245 & 990 & 242,600 \\
\hline & 84 & 255 & 750 & 191,300 \\
\hline & 66 & 195 & 555 & 108,200 \\
\hline & 48 & 65 & 420 & 27,300 \\
\hline & 30 & 70 & 225 & 15,800 \\
\hline
\end{tabular}

\begin{tabular}{|c|c|c|c|c|}
\hline I tem & $\begin{array}{c}\text { Diameter, } \\
\text { in. }\end{array}$ & Qty & $\begin{array}{l}\text { Unit Cost, } \\
\text { \$/each } \\
\end{array}$ & $\operatorname{Cos} t, \$$ \\
\hline \multirow[t]{7}{*}{ Tees } & $138-30$ & 6 & 115,800 & 694,800 \\
\hline & $120-30$ & 5 & 89,000 & 445,000 \\
\hline & $102-30$ & 4 & 48,900 & 195,600 \\
\hline & $84-30$ & 4 & 32,700 & 130,800 \\
\hline & $66-30$ & 3 & 20,600 & 61,800 \\
\hline & $48-30$ & 1 & 7,900 & 7,900 \\
\hline & $30-30$ & 1 & 3,800 & 3,800 \\
\hline \multirow[t]{8}{*}{ Reducers } & $138-120$ & 1 & 115,000 & 115,000 \\
\hline & $120-102$ & 1 & 73,000 & 73,000 \\
\hline & $102-84$ & 1 & 19,300 & 19,300 \\
\hline & $84-66$ & 1 & 13,500 & 13,500 \\
\hline & $66-48$ & 1 & 7,100 & 7,100 \\
\hline & $48-30$ & 1 & 4,700 & 4,700 \\
\hline & & & & $\$ 3,980,000$ \\
\hline & \multicolumn{3}{|r|}{ \& Return) } & $\$ 7,993,000$ \\
\hline
\end{tabular}




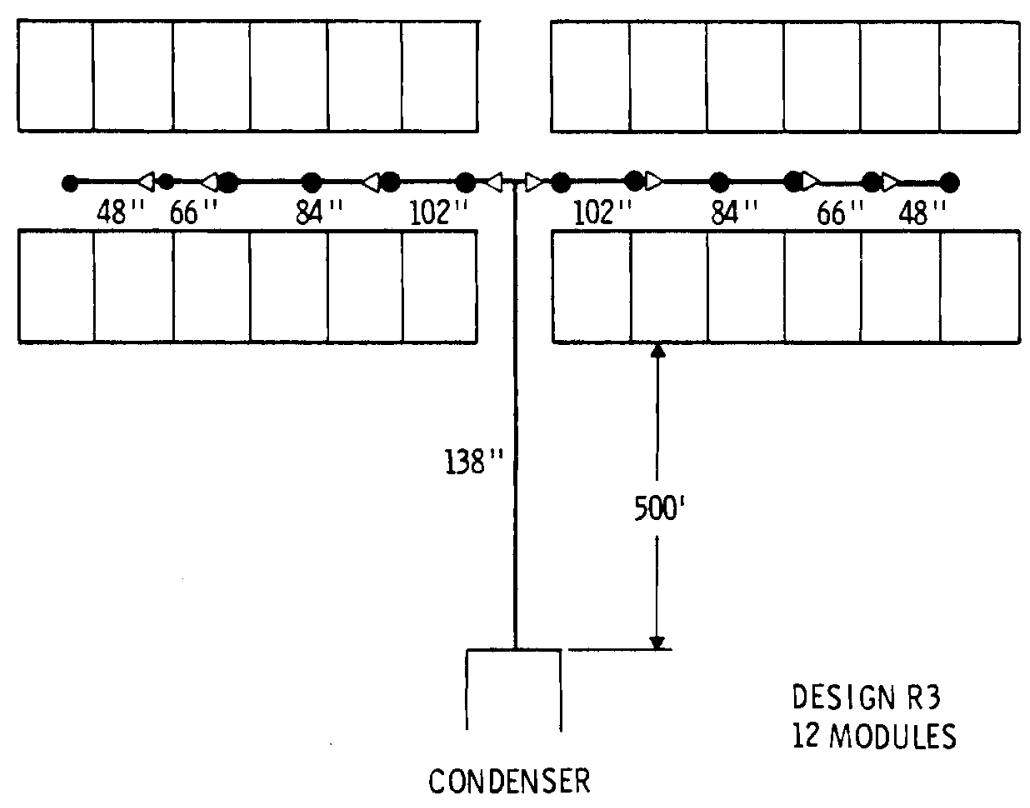

FIGURE 5-13. Rectilinear Tower Main Circulation Piping Design R3

TABLE 5-14. Main Circulation Piping Design R3 Cost Estimate

\begin{tabular}{|c|c|c|c|c|}
\hline Item & $\begin{array}{c}\text { Diameter, } \\
\text { in. }\end{array}$ & $\begin{array}{l}\text { Length, } \\
\mathrm{ft}\end{array}$ & $\begin{array}{l}\text { Unit Cost, } \\
\$ / \mathrm{ft}\end{array}$ & $\cos t, \$$ \\
\hline \multirow[t]{5}{*}{ Pipe } & 138 & 600 & 1,555 & 933,000 \\
\hline & 102 & 265 & 990 & 262,300 \\
\hline & 84 & 540 & 750 & 405,000 \\
\hline & 66 & 275 & 555 & 152,600 \\
\hline & 48 & 280 & 420 & 117,600 \\
\hline
\end{tabular}

\begin{tabular}{|c|c|c|c|c|}
\hline Item & $\begin{array}{c}\text { Diameter, } \\
\text { in. }\end{array}$ & Qty & $\begin{array}{l}\text { Unit Cost, } \\
\quad \$ / \text { each } \\
\end{array}$ & $\cos t, \$$ \\
\hline \multirow[t]{5}{*}{ Tees } & $138-138$ & 1 & 171,000 & 171,000 \\
\hline & $102-42$ & 4 & 49,300 & 198,800 \\
\hline & $84-42$ & 4 & 33,100 & 132,400 \\
\hline & $66-42$ & 2 & 21,000 & 42,000 \\
\hline & $48-42$ & 2 & 8,300 & 16,600 \\
\hline \multirow[t]{6}{*}{ Reducers } & 138-102 & 2 & 188,000 & 376,000 \\
\hline & $102-84$ & 2 & 19,300 & 38,600 \\
\hline & $84-66$ & 2 & 13,500 & 27,000 \\
\hline & \multirow[t]{3}{*}{$66-48$} & 2 & 7,100 & 14,200 \\
\hline & & & & $2,887,000$ \\
\hline & & Cost & \& Return) & $\$ 5,981,000$ \\
\hline
\end{tabular}


TABLE 5-15. Capital Cost Comparison of Three Piping System

Designs for Rectilinear Towers

\begin{tabular}{|c|c|c|c|}
\hline & \multicolumn{3}{|c|}{ Cost in Millions of Dollars } \\
\hline & Design RT & Design R2 & Design R3 \\
\hline Pump Station & 1.577 & 1.577 & 1.577 \\
\hline Module Piping & 3.988 & 4.051 & 3.988 \\
\hline Circulation Piping & 6.837 & 7.993 & 5.981 \\
\hline & 12.40 & 13.62 & 11.55 \\
\hline
\end{tabular}

Designs R1 and R2 differ only in terms of the degree of cooling system control. If power plant operating experience showed that resolution of the cooling system to about 40 MWe was required, then Design R2 would be used. Otherwise, Design Rl allows control of the cooling system to about 80 MWe. It is believed that this would cover the range of most applications.

Cooling system designs are compared on a relative basis. The impact of choosing Design R1 over Design R3 should have little effect on the comparison of various optimized designs. As an example, begin with two sets of cooling system design conditions. Develop an optimized cooling system for each set of conditions using Design R1 as the piping model. Now compare the overall costs and design of each system. Certain trends will be apparent between the two designs. Repeat the optimization and comparison using Design R3 as the piping model. The trends observed in the first case will be evident again.

\subsection{PIPING DESIGN AND COST ALGORITHM OUTLINE}

The following is an outline of the design and cost algorithm for the piping system. This algorithm performs two basic functions. First, it calculates the cost of all the piping and pumps between the condenser and the heat exchanger. Second, it determines the pressure drop in the piping system so that the total system pumping power requirements can be determined.

1. Input:
a) Total Flow of Coolant
b) Design Velocity 
c) Number of, and Diameter of, Circular Towers

d) Distance from Condenser to Towers

e) Width of Tube Bundle

f) Water-Side Pressure Drop in the Heat Exchanger and the Condenser

2. Divide the total flow by the number of towers to obtain the flow to each tower.

3. I - 1 ( $I$ is an index that applies to successive sections of the header.)

4. Determine the required diameter of header section I, based on the coolant flow rate and the coolant design velocity.

5. It is assumed that pipe is available in size increments of 6 inches. Select DIAMETER (I) from the next largest incremental size.

6. If $I=1$, go to 9

7. It has been assumed that reducer prices apply whether the reduction is 6,12 , or 18 inches. This is based on a standard reducer length of 2 feet and an included angle of $221 / 2^{\circ}$. If DIAMETER ( $I$ ) is not less than DIAMETER (I-1) by the size of the reduction (an input value which can be either 6,12 , or 18 inches) then set DIAMETER ( $I$ ) equal to $\operatorname{DIAMETER}(I-1)$. In any other case, $\operatorname{DIAMETER}(\mathrm{I})=(\mathrm{I}-1)$ - the reduction.

8. If a reduction has been made, then determine a reducer cost.

9. Determine the cost of pipe and a tee for header section I.

10. Determine the equivalent length of pipe and the true velocity of flow in header section I.

11. Determine the pressure drop in header section I.

12. Subtract out the flow to one tee. (This could be the flow to one circular tower or one tube bundle, depending on whether the header being designed is the main circulation header or the quadrant header.) Determine the flow remaining in header section $I+1$.

13. If the flow remaining equals zero, go to 15 .

14. $I=I+1$, go to 4 . 
15. Determine miscellaneous costs such items as valves, expansion joints, bundle fittings, etc.

16. If the quadrant header has been designed then go to 19 .

17. The quadrant header is designed similarly to the main circulation header. The total number of tube bundles and the flow to each quadrant and to each tube bundle can be determined from the input conditions.

18. Reset the index $I=1$ and go to 4 .

19. Size the tower distribution piping according to the design velocity and the flow to each tower and to each quadrant.

20. The total length of pipe for the four distribution lines between the tower distribution header and each quadrant is assumed to be 3.25 times the tower diameter. Determine the cost of this pipe and all other tower distribution pipe, fittings and valves.

21. Determine the equivalent length and the pressure drop for the tower distribution piping.

22. Determine the equivalent length and the pressure drop for the pump station.

23. Sum the pressure drops for the entire cooling system.

24. Pump station costs are determined from the total flow and the total system dynamic head loss.

25. Sum all costs for the supply and return piping. 


\subsection{STEAM CONDENSERS}

There are two basic steam condenser types: direct-contact and surface. In the direct-contact condenser, the steam and the cooling water are mixed to condense the steam. This type, sometimes referred to as the barometric or ejector-jet condenser, is used in the Heller dry cooling system.

The surface condenser is a shell and tube structure in which the steam is admitted to the shell and is condensed on the outside of the tubes. The cooling water enters through water boxes and flows through the tube bundle in one or more passes. The coolant and steam do not mix, allowing the use of cooling water of a lower quality than the condensate. The lower water qualities would be experienced in combination evaporative or deluge cooling systems discussed in Section 8.0. With modifications of the condenser design, other coolants such as ammonia could be used. Only the surface condenser has been costed for this program to date.

\subsection{WATER-COOLED SURFACE CONDENSERS}

- The condenser size and design features, such as the single or multipressure feature, are determined by the turbine characteristics and the calculated heat load. This information is obtained from a subroutine in the economic analysis code. The condenser cost consists basically of the condenser tube, shell, and installation costs.

\subsubsection{Condenser Tubing}

The condenser tubing cost is a function of the tube material, size, gage, length and number of tubes. This information results from the condenser performance calculations. The cost algorithms and cost data developed in Section 3.2.1 for tubular cooling surfaces and liners can be used for the condenser tubing as wel1. The cost data in Table 3-2 includes the commonly used condenser tubing such as admiralty and copper-nickel as well as the more costly titanium alloy tubing. 


\subsubsection{Condenser She11}

The shell costing is based on a condenser manufacturer's price list ${ }^{\text {(23) }}$ (December 1973, modified) which is for surface condensers for land installations. A basic shell price is presented as a function of the condenser tube $O D$ and the number of tubes. Price factors are presented for various condenser design alternatives such as:

- condenser length

- multi-pressure features

- tube sheet materials and thickness

- water box materials and types

- water box pressures

- shell and tube support materials

- condensate storage depths

- tube bundle intermediate connectors

- shell and water box internal and external surface preparations.

Price additions are also available for several auxiliary condenser items such as:

- expansion joints and turbine flanges

- steam dump capability

- extended steam inlet neck

- hotwell alternatives

- backwash provision

- feedwater heater shell supports and extraction piping

- others.

Cost algorithms were developed for the condenser shell costs as follows: She $11 \operatorname{cost}\left(C_{C S}\right)=\left[C_{B S}\left(C F_{L}+C F_{m p}+C F_{C S}\right)+C_{A U X}\right] N_{C S}$

where

$$
\begin{aligned}
& N_{C S}=\text { number of condenser shells } \\
& C_{B S}=\text { basic condenser shell costs (\$/shel1). }
\end{aligned}
$$


Algorithms were developed for the basic shell costs as a function of the number of tubes for each standard tube size from $3 / 4$ inch $0 D$ to $1-1 / 4$ inches OD as follows:

$$
C_{B S}=A_{B S} N_{C t}+B_{B S}
$$

where

$$
\begin{aligned}
& N_{C t}=\text { number of condenser tubes per shell } \\
& A_{B S}=\text { unit factor per tube for tube size being considered } \\
& B_{B S}=\text { factor constant for tube size being considered }
\end{aligned}
$$

Table 6-1 lists the basic shell cost factors for various tube ODs.

The following relation was developed for the shell length correction factor $\left(C F_{L}\right)$ :

$$
C F_{L}=\left(F_{t l}+F_{s m}+F_{c s} \Delta d_{c}\right) L_{c t}+0.58
$$

where

$$
\begin{aligned}
L_{c t}= & \text { length of condenser tubing }(\mathrm{ft}) \\
F_{t \ell}= & \text { tube length correction factor } \\
= & 0.0153 \text { (basic length is } 28 \mathrm{ft} \text { ) } \\
F_{S m}= & \text { shel1 and tube support material factor } \\
= & 0.00042 \text { for ASTM A-285 C } \\
& \text { instead of A-283 C } \\
F_{C S}= & \text { condensate storage depth factor } \\
= & 0.000035 / \text { in. } \\
\Delta d= & \text { depth of condensate storage over } 9 \text { inches (in.). }
\end{aligned}
$$




\section{TABLE 6-1. Basic She11 Cost Factors}

Tube Diameter

\begin{tabular}{|c|c|c|}
\hline (in.) & $A_{B S-}$ & \\
\hline $3 / 4$ & 7.696 & 97,125 \\
\hline $7 / 8$ & 8.806 & 102,165 \\
\hline 1 & 10.836 & 102,181 \\
\hline $1-1 / 8$ & 12.955 & 103,273 \\
\hline $1-1 / 4$ & 15.223 & 102,237 \\
\hline
\end{tabular}

The basic shell cost is for a single-pressure single-shell condenser. Following are the factors for $\mathrm{CF}_{\mathrm{mp}}$ when multi-pressure and/or multi-shell condensers are used:

$$
\begin{aligned}
C F_{m p}= & 0.08 \text { for } 1 \text { she } 11,2 \text { pressures } \\
= & 0.16 \text { for } 1 \text { she } 11,3 \text { pressures } \\
= & 0.03+N_{c s}(0.02) \text { for } 2 \text { she } 11 \mathrm{~s}, 2 \text { pressures } \\
& \text { or } 3 \text { shells, } 3 \text { pressures. }
\end{aligned}
$$

The factor $C_{C S}$ primarily covers variations in the tube sheets, water boxes, water box pressure, and shell and water box surface preparations. The basic shell costs include a Muntz metal tube sheet, carbon steel semicylindrical water boxes, a 30-psi water box pressure, and no surface preparation. The following relation was developed to allow estimating costs of some alternative tubing alloys using compatible tube sheet and water boxes (design pressure, 46 to 55 psi) and protective coatings on the condenser shell and water boxes:

$$
\mathrm{CF}_{c s}=\left(A_{c s} \ln N_{c t}-B_{c s}\right) f_{t d}
$$

where

$$
\begin{aligned}
C F_{C S}= & \text { cost factor for condenser shell variations } \\
N_{C t}= & \text { number of tubes per she } 11 \\
A_{C S}= & \text { unit factor for combination being considered, } \\
& \text { see Table } 6-2 \\
B_{C S}= & \text { factor constant for combination being considered, } \\
& \text { see Table } 6-2 .
\end{aligned}
$$


TABLE 6-2. Tube Sheet and water Box Factors

$$
\begin{aligned}
& \text { Combination } \\
& \mathrm{A}_{\mathrm{CS}}-\mathrm{B}_{\mathrm{CS}}
\end{aligned}
$$

\begin{tabular}{cc} 
Tube OD (in.) & $\mathrm{f}_{t d-}$ \\
\hline $3 / 4$ and $7 / 8$ & 0.95 \\
1 and $1-1 / 8$ & 1.00 \\
$1-1 / 4$ & 1.05
\end{tabular}

The cost of the condenser equipment auxiliaries is difficult to estimate without the plant and turbine design detail. The cost of the auxiliaries is primarily dependent upon the steam flow to the condenser. This can roughly be approximated by the condenser surface area. Using a probable list of auxiliaries, the following cost algorithm was developed:

$$
\begin{aligned}
& C_{A U X}=0.30\left(A R_{C}\right) \\
& C_{A U X}=\text { auxiliary equipment cost/shell }(\$) \\
& A R_{C}=\text { condenser tubing } 00 \text { surface area }\left(\mathrm{ft}^{2} / \text { she } 11\right) .
\end{aligned}
$$

\subsubsection{Condenser Erection}

The condenser erection cost is a function of the condenser size, which can be expressed as a function of the surface area. These costs are 
dependent upon the labor work rate and the labor cost, both of which vary considerably across the country. Using an average work rate of 14 manhours $/ 100 \mathrm{ft}^{2}$ supplied by a condenser manufacturer and an average labor rate for pipefitters from the 1975 Construction Review gave the following cost per $100 \mathrm{ft}^{2}$ condenser surface:

\section{$\$ 9.50 / \mathrm{hr}$ wage \\ $1.25 / h r$ payroll burden \\ $\$ 10.75 / \mathrm{hr}$ total}

Assuming the contractor's overhead of 67 percent of labor costs leads to the following unit cost $\left(C_{e r}\right)$ :

$$
C_{e r}=\frac{14(10.75)}{100}(1.67)=\$ 2.51 / \mathrm{ft}^{2}
$$

Total contractor's erection costs less profit $\left(C_{E R}\right)$ then can be expressed as:

$$
\begin{aligned}
C_{E R} & =C_{\text {er }}(A R) N_{C S} \\
C_{e r} & =\text { unit erection costs } \\
& =\$ 2.51 / \mathrm{ft}^{2} \\
A R & =\text { condenser surface area per shell }\left(\mathrm{ft}^{2} / \mathrm{shell}\right) \\
N_{C S} & =\text { number of condenser shells. }
\end{aligned}
$$

\subsubsection{Total Condenser Cost}

The "onsite" condenser cost will then be the tubing cost $C_{\text {st }}$ (see Section 6.1.1), plus the shell cost $C_{S C}$ (see Section 6.1.3) times the manufacturer's multiplier of 0.88 and a shipping cost factor of 14 percent:

$$
C_{S C}=\left[\left(C_{S C}\right) 0.88\right] 1.14
$$

This cost added to the erection cost $C_{E R}$ (see Section 6.1.3) plus a general contractor's profit of 10 percent gives the total installed condenser price as :

$$
C_{C O N}=\left\{\left[\left(C_{C S}\right) 0.88\right] 1.14+C_{C t}+C_{E R}\right\} 1.10 .
$$




\subsection{CONDENSERS FOR AMMONIA COOLANT}

When ammonia is used as a coolant, the steam condenser becomes a condenser/reboiler where the ammonia is vaporized in the tubes as the steam is condensed in the shell. This condenser is envisioned as a modification of the standard steam condenser to accommodate $400 \mathrm{psi}$ tube and header box pressure, aluminum tubes with enhanced boiling and condensation surfaces, aluminum tube sheet, and welded tube-to-tube sheet joints. Stainless steel impingement shields must also be provided to protect the aluminum tubes from steam erosion.

The aluminum tubes with both internal and external enhanced cooling surfaces are estimated at $\$ 1.40$ to $\$ 1.80$ per foot for 1 inch 00 by 12 gage tubes. This cost, together with a handling and overhead factor of 10 percent, leads to the following equation:

$$
c_{c t} \approx\left(1.60 L_{c t} N_{c t} N_{c s}\right) 1.10
$$

where

$$
\begin{aligned}
& C_{c t}=\text { condenser tubing cost per shell } \\
& L_{c t}=\text { length of condenser tubing }(\mathrm{ft}) \\
& N_{c t}=\text { number of tubes per shell } \\
& N_{c s}=\text { number of condenser shells. }
\end{aligned}
$$

The condenser she 11 is estimated at 5 percent over a comparable watercooled condenser shell with Muntz metal tube sheets and steel water boxes. Assuming the reference water-cooled condenser has steel rectangular water boxes with a design pressure of 76 to 100 psi leads to the following relation for an ammonia condenser shel1 price:

where

$$
C_{C S} \approx\left[C_{B S}\left(C F_{L}+C F_{m p}+C F_{C S}\right)+C_{A U X}\right] N_{C S} F_{A M}
$$

$$
\begin{aligned}
& C_{B S}=\text { basic she } 11 \text { cost }(\$ / \text { she } 11) \text { (see Section } 6.1 .2 \text { ) } \\
& C F_{L}=\text { condenser length factor (see Section } 6.1 .2 \text { ) }
\end{aligned}
$$




$$
\begin{aligned}
C F_{\mathrm{mp}} & =\text { multi-pressure and shell factor (see Section } 6.1 .2) \\
C F_{C S} & =\text { condenser shell variation factor } \\
\approx & 0.04821 \mathrm{n} \mathrm{N}_{\mathrm{Ct}}-0.1669 \\
C_{A U X}= & \text { auxiliary equipment cost/shell }(\$) \text { (see Section } 6.1 .2) \\
\mathrm{N}_{C S}= & \text { number of condenser shells } \\
F_{A M}= & \text { estimated factor for an equivalent } 400 \text { psi ammonia condenser } \\
& \text { reboiler } \\
\approx & 1.05
\end{aligned}
$$

The condenser erection costs will be higher due to the tube-to-tube sheet weld. Assuming this to be an approximate 10 percent increase leads to a unit erection cost ( $C_{\text {er }}$, see Section 6.1 .3 ) of $\$ 2.75 / \mathrm{ft}$ of condenser surface area. The total installed condenser cost can be determined by applying the same factors as described in Section 6.1.4. 


\subsection{STRUCTURES}

Cost algorithms were developed for the two predominant configurations of mechanical draft dry cooling towers, i.e., rectangular and circular structures. Both shapes are in use by the cooling tower industry.

\subsection{RECTANGULAR TOWER ARRANGEMENT COST ALGORITHMS}

The structure cost algorithm for a rectangular arrangement covers the site clearing and grading, excavation and backfilling for foundations, foundation costs, and steel supporting structure costs, (columns, beams, wind bracing, paint). It does not cover other items, such as the tube bundles, plenums, fans, piping or pipe supports. So that the results from the cost algorithm would be realistic, the initial cost estimate was based on a commercial design for a rectangular dry cooling system, shown in Figure 7-1. For the initial estimate, site conditions were assumed to provide average to good allowable

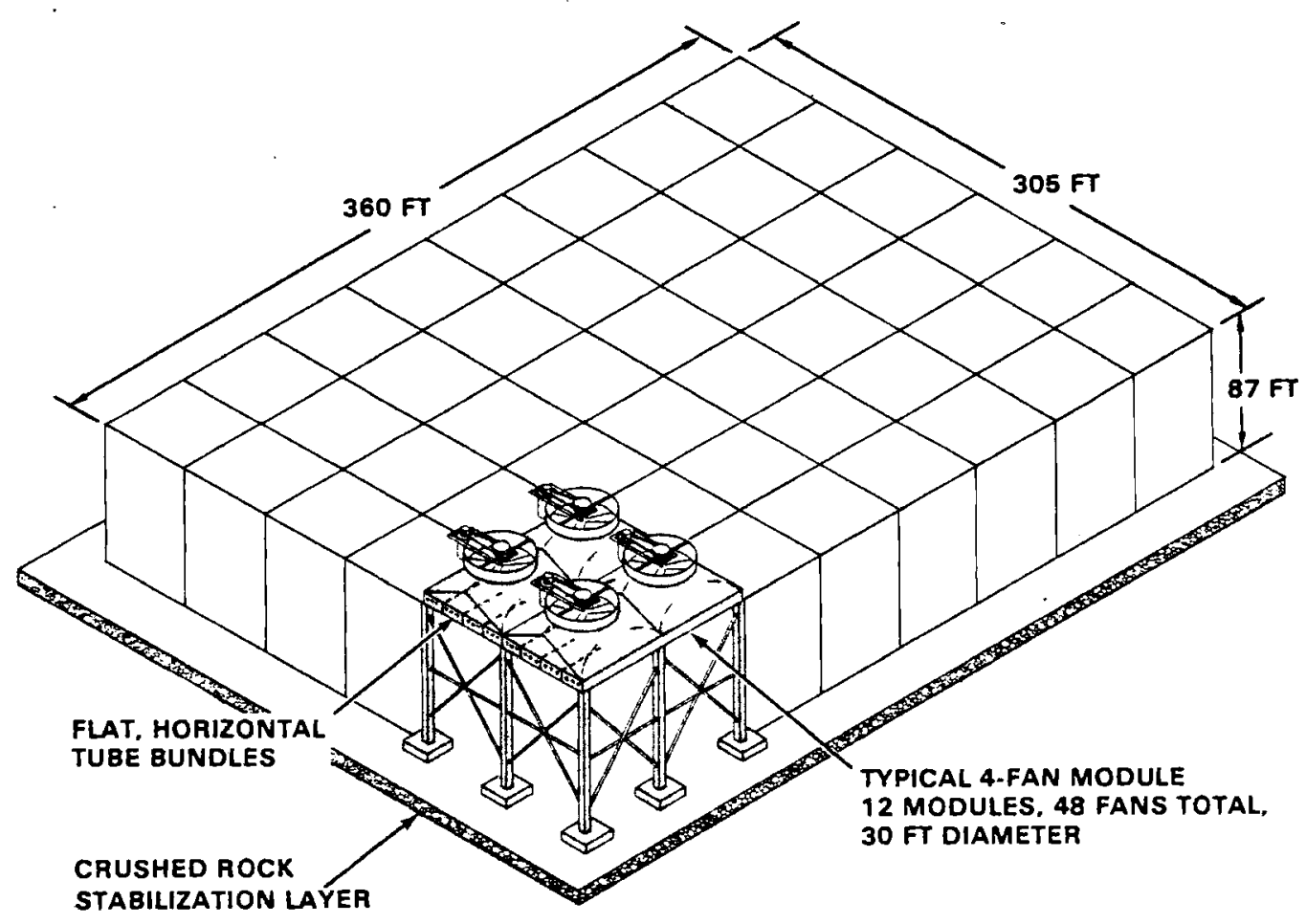

FIGURE 7-1. Typical Flat Horizontal Dry Cooling Tower Structure Arrangement 
soil loading (up to 6,000 psf) and a reasonably level site. Costs were based on Los Angeles, California, with a geographical cost adjustment index of 100. (24) The geographical cost adjustment index allows estimated costs to be adjusted for any of 107 major cities in the United States.

\subsubsection{Development of the Cost Algorithms}

This section describes the development and basis of the algorithms used in the Battelle optimization program for a horizontal, rectangular, dry cooling tower arrangement.

\subsubsection{Initial Structure and Foundation Costs}

A base case cost was needed from which costs could be derived for towers which were larger, smaller, or for which the tube lengths or the total load to be supported varied. From data available from vendor drawings and other sources, the structure costs were computed:

Given a horizontal, rectangular, indirect dry cooling tower of plan dimensions $305 \mathrm{ft} \times 360 \mathrm{ft}$ and having 96 tube bundles of $12 \mathrm{ft} \times 80 \mathrm{ft}$ $\times 2 \mathrm{ft}$ each and 48 fans, the weights and other pertinent data are:

$\begin{array}{lr}\text { Total weight of supporting steel } & 3,393,000 \mathrm{lb} \\ \text { Total weight of other structural } & \\ \text { elements } & 2,206,000 \mathrm{lb} \\ \text { Total weight of fin-tube bundles } & 4,339,000 \mathrm{lb} \\ \text { Total weight of tower machinery } & \\ \text { (fans, plenums) } & 362,000 \mathrm{lb} \\ \text { Snow load } & 40 \mathrm{lb} / \mathrm{ft}^{2} \\ \text { Total frontal area } & 92,160 \mathrm{ft}^{2} \\ \text { Total plan area } & 109,620 \mathrm{ft}^{2} \\ \text { Weight of water in bundles } & 609,000 \mathrm{lb}\end{array}$

From the above data, the site assumptions, and the unit prices from the 1976 Building Cost File, ${ }^{(24)}$ the following structure costs were estimated. 
Steel Costs

Columns 1696.5 tons $\times 1036.66^{(a)}$

$$
\times 1.1^{(b)} \times 1.1^{(b)}=\$ 2,128,000
$$

Beams and misc.

$$
1103 \text { tons } \times 1073.65^{(\mathrm{a})} \times 1.21^{(\mathrm{b})}=\frac{1,433,000}{\text { TOTAL INSTALLED COST }}
$$

Foundation Costs

Site grading and compaction

$$
10,350 \mathrm{yd}^{3} \text { at } \$ 2.70 / \mathrm{yd}^{3}
$$

Disposal

$$
4,200 \mathrm{yd}^{3} \text { at } \$ 2.38 / y \mathrm{~d}^{3}
$$$$
=9,996
$$

Structure excavation

$$
400 \mathrm{yd}^{3} \text { at } \$ 3.75 / \mathrm{yd}^{3}
$$

Structure backfill

$$
100 \mathrm{yd}^{3} \text { at } \$ 4.70 / \mathrm{yd}^{3}
$$

$=$

470

Footings

63 at $\$ 437.00$ each

Six-inch thick compacted, graded gravel layer

on and around base

$3450 \mathrm{yd}^{3}$ at $\$ 16.57 / \mathrm{yd}^{3}$

SUBTOTAL

$10 \%$ OVERHEAD + 10\% MARKUP

TOTAL INSTALLED COST

ROUND TO $=\quad 27,531$

$=\quad 57,166$

$\$ 124,608$

$\frac{26,167}{\$ 150,776}$

$\$ 150,000$

(a) ASTM A-36 steel, bolted connections, stock sections, shop primed with red lead, two field coats red oxide. Prices include shop fabrication and delivery.

(b) Ten percent overhead and 10 percent general contractor's markup. 


\subsubsection{Rectangular Arrangement Cost Algorithms}

It was desired to model the change of structure cost as a function of fin-tube frontal area when the tube length and the number of tube rows were varied within a bundle. The cost of the structure itself, not including foundation costs, is $\$ 38.64$ per square foot of fin-tube frontal area.

Algorithm 1. Changes in tube length which do not change the total bundle weight or frontal area will not change the structure cost. This is because while the span may change, the column arrangement and knee braces can be changed to reduce the effects of span changes, and horizontal steel remains the same. The total weight to be supported is the same and vertical (column) steel is not affected. Because total weight to be supported does not change, and occupies the same area, the supporting structure is not affected overall.

Algorithm 2. If modifications change the bundle weight (but not the frontal area), then the supporting steel will be affected. When the weight is changed, the new cost per square foot of frontal area will be of the form $A+$ ( $B$ times the weight in pounds per square foot of the new bundle plus water in the bundle plus tower machinery plus live load, e.g., snow load).

The cost algorithm for a weight change without area change is:

$$
C=\$ 15.00+0.242 W
$$

in which

$$
\begin{aligned}
C= & \text { new cost } / \mathrm{ft}^{2} \text { of frontal area } \\
\mathrm{W}= & \text { the weight in } 1 \mathrm{~b} / \mathrm{ft}^{2} \text { of the new bundle plus tower machinery } \\
& \text { plus water in the bundle plus live load, such as snow load. }
\end{aligned}
$$

For the base design, a snow load of $40 \mathrm{lb} / \mathrm{ft}^{2}$ was used.

Algorithm 3. If the frontal area is changed without a change in weight per bundle (or weight per square foot), then the structure cost will vary in direct proportion to the area at a cost of $\$ 38.64 / \mathrm{ft}^{2}$ of frontal area. 
Algorithm 4. If the area and weight are changed simultaneously, the new cost/ft ${ }^{2}$ is computed as in Algorithm 2, and multiplied by the new frontal area to obtain total structural steel cost.

Algorithm 5. The foundation costs for the base case are estimated at $\$ 150,000$. This is for a total load of $10,300,7501 \mathrm{~b}$ (steel + bundles + tower machinery) plus 609,000 1b (water) plus 4,383,800 1b (snow load, 40 psf on $\left.109,620 \mathrm{ft}^{2}\right)=15,294,550 \mathrm{lb}$. This is a foundation cost of $\$ 0.001$ per pound of load to be supported. To obtain new foundation costs, multiply the new total load in pounds by $\$ 0.001$.

\subsubsection{Algorithm Bases}

Algorithm 1 states that tube length changes will not change the structure cost if the total bundle weight and frontal area are not changed. If frontal area and load are not changed, there will be no significant change to the structure.

Reference 25 establishes factors for vertical support assembly costs and primary framing assemblies. Vertical support factors are based on load, number of floors, height, and bay size. The load factor establishes that if the load is the same, the cost is the same. The bay size factor shows different costs depending upon bay size. But the chosen rectangular design has a module size of 90 feet by 101.5 feet, further subdivided into bays of 45 feet by 50.75 feet. The limits of tube lengths to be considered were 80 to 100 feet (maximum shipping length) and 40 feet minimum. Such lengths can be accommodated on the framework without significant modification in the bay size. Hence, neither the vertical steel nor the primary framing will be affected and the cost will not vary. Of the two other factors, number of floors is not applicable to this structure and the structure height is not varied.

Algorithm 2 treats the case of a weight change without frontal area change. The basis for this algorithm is described below.

Reference 25 shows the relationship between load in $1 \mathrm{~b} / \mathrm{ft}^{2}$ and cost for vertical support assemblies (columns) and primary framing assemblies by means 
of load factors. In Table 7-1, these factors were applied to the cost of the steel assumed to be columns $(\$ 2,128,000)$ and that assumed to be primary framing $(\$ 1,433,000)$; new costs per square foot of frontal area were obtained, plotted and put into equation form (see Figure 7-2).

Thus, base case weight $=4,339,0001 \mathrm{~b}$ bundle weight

$$
\begin{aligned}
& 609,0001 \mathrm{~b} \text { water weight } \\
& 362,0001 \mathrm{~b} \text { tower machinery weight } \\
& 5,310,0001 \mathrm{~b}
\end{aligned}
$$

$5,310,0001 \mathrm{~b} / 92,160 \mathrm{ft}^{2}$ of frontal area

$$
\begin{aligned}
& =57.6 \mathrm{1b} / \mathrm{ft}^{2} \text { bundle + water }+ \\
& \text { machinery } \\
& \frac{40.0 \mathrm{~b} / \mathrm{ft}^{2} \text { snow }}{97.6 \mathrm{bb} / \mathrm{ft}^{2}}
\end{aligned}
$$

The base case is 97.6 psf (rounded to 100 psf).

The equation for Algorithm 2 is based on a straight line fit to the points and calculates slightly different costs than the individual calculations. However, the costs are within 1.4 percent as shown in Table 7-2.

\begin{tabular}{|c|c|c|c|c|c|}
\hline $\begin{array}{l}\text { Column } \\
\text { Factor }\end{array}$ & $\begin{array}{l}\text { Framing } \\
\text { Factor } \\
\end{array}$ & $\begin{array}{l}\text { Load (a) } \\
1 \mathrm{~b} / \mathrm{ft}^{2}\end{array}$ & $\begin{array}{c}\text { Column } \\
\text { Cost } \\
\$ / \mathrm{ft}^{2} \\
\end{array}$ & $\begin{array}{l}\text { Framing } \\
\$ / \mathrm{ft}^{2} \\
\end{array}$ & $\begin{array}{l}\text { Total } \\
\text { Cost } \\
\$ / \mathrm{ft}^{2} \\
\end{array}$ \\
\hline 0.9 & 0.82 & 75 & 20.78 & 12.75 & 33.53 \\
\hline 1.0 & 1.0 & 100 & 23.09 & 15.55 & $38.54^{(b)}$ \\
\hline 1.25 & 1.4 & 150 & 28.86 & 21.77 & 50.63 \\
\hline 1.6 & 1.7 & 200 & 36.94 & 26.43 & 63.37 \\
\hline
\end{tabular}

Algorithm 3 states that the structure cost varies in direct proportion to the area if there is no load change. Within reasonable limits, e.g., a structure one-half as large to one twice as large as the base case, with only one story or floor involved, it is commonly accepted practice to estimate costs based on plan area.

TABLE 7-1. Structure Costs as a Function of Load

\footnotetext{
(a) Weight in $1 \mathrm{~b} / \mathrm{ft}^{2}$ of tube bundles, water in bundles, tower machinery, and snow load.

(b) Base case.
} 


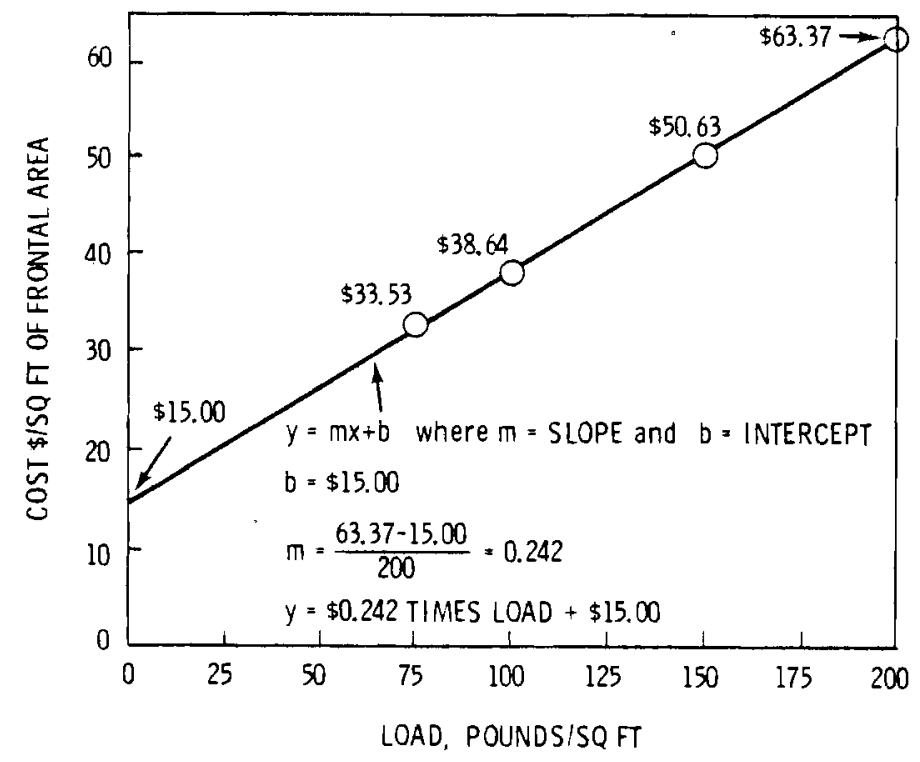

FIGURE 7-2. Horizonta] Dry Cooling Tower Structure Costs as a Function of Load

TABLE 7-2. Accuracy of Cost Model Compared to Individual Calculations

\begin{tabular}{|c|c|c|c|}
\hline $\begin{array}{l}\text { Load }_{2} \\
1 \mathrm{~b} / \mathrm{ft}^{2}\end{array}$ & Cost Model Cost, $\$ / \mathrm{ft}^{2}$ & $\begin{array}{c}\text { Individual Cal- } \\
\text { culations Cost, } \\
\$ / \mathrm{ft}^{2}\end{array}$ & $\begin{array}{c}\text { Percent } \\
\text { Difference }\end{array}$ \\
\hline 75 & $15.00+18.15=33.15$ & 33.53 & -1.1 \\
\hline 100 & $15.00+24.20=39.20$ & 38.64 & +1.4 \\
\hline 150 & $15.00+36.30=51.30$ & 50.63 & +1.3 \\
\hline 200 & $15.00+48.40=63.40$ & 63.37 & 0.0 \\
\hline
\end{tabular}

Algorithm 4 simply combines the effects of Algorithms 2 and 3 for weight and area changes when they occur simultaneously.

Algorithm 5 is a separate algorithm for the foundation cost. It is based on the relationship that foundation cost is generally proportional to the weight to be supported. In an effort to keep the algorithm simple, the relationship of the foundation cost to the total plan area was neglected. This omission may introduce a small error into the calculations, but because the foundation costs are only 4 percent of the costs for this particular structure, this error is negligible. 


\subsection{CIRCULAR TOWER ARRANGEMENT COST ALGORITHMS}

The circular tower arrangement consists of fin-tube bundles mounted vertically around the periphery of a round tower having fans in the roof, as in Figure 7-3. The tube bundles may be arranged in either a flat (tangent to the circle) or delta (V-bank) configuration.

The algorithms for a round tower also covered the foundation cost separately from the steel structure costs. Foundation costs included the necessary clearing, grading, excavation and backfilling, as well as the footings. Again, to provide a meaningful, practical cost estimate, the initial estimate was based on a design by a commercial manufacturer.

\subsubsection{Development of the Cost Algorithms}

The development and basis for the algorithms are described in the following paragraphs.

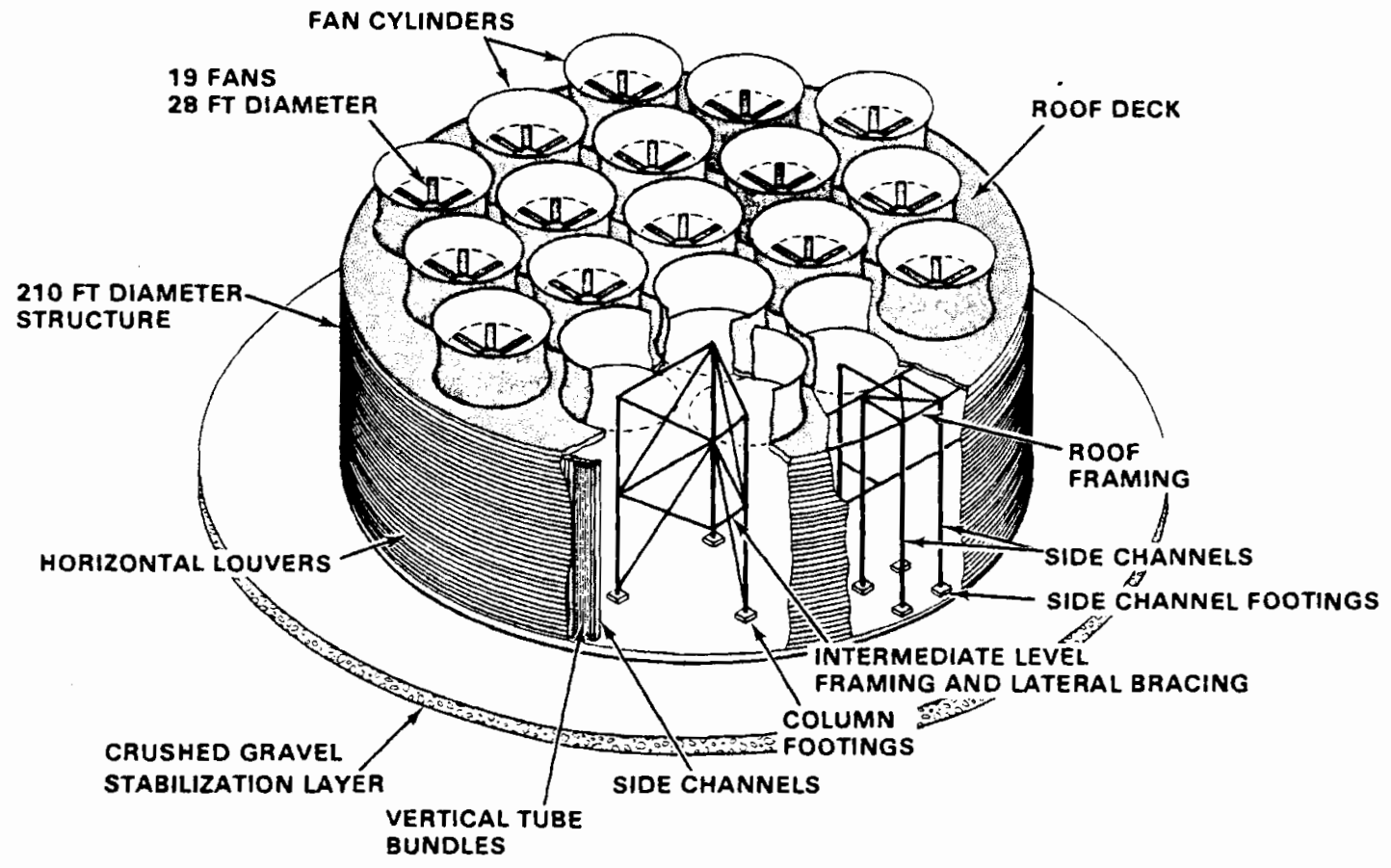

FIGURE 7-3. Typical Circular Dry Cooling Tower Structure Arrangement 


\subsubsection{Initial Structure and Foundation Costs}

Data from vendor drawings and other sources provided a design for computing structure costs as follows:

Given an arrangement of 54 modules around the periphery of two round towers, each 210 feet in diameter and approximately 66 feet high to the fan deck with 19 fans per tower, 108 bundles each $12 \mathrm{ft} \times 60 \mathrm{ft}$ by $2 \mathrm{ft}$, the weights and other pertinent data (two towers) are:

Total weight of supporting steel $1,546,00016$

Total weight of other structural elements

Total weight of fin-tube bundles $94,0001 \mathrm{~b}$

Total weight of tower machinery

$$
\text { (fans, fan cylinders) }
$$

Snow load (on roof area)

Total frontal area

Total plan area

$$
\begin{gathered}
2,484,000 \mathrm{lb} \\
509,200 \mathrm{lb} \\
40 \mathrm{lb} / \mathrm{ft}^{2} \\
77,760 \mathrm{ft}^{2} \\
69,280 \mathrm{ft}^{2} \\
500,000 \mathrm{lb} \\
47,048 \mathrm{ft}^{2}
\end{gathered}
$$

Weight of water in bundles

Galvanized platforms

From the above data, the site assumptions and unit prices, $(24)$ the following structure costs were estimated.

\section{Steel Costs}

Main structural steel

$$
820 \text { tons } \times \$ 1050.00^{(a)} \times 1.21^{(b)} \quad=\$ 1,041,810
$$

Galvanized platforms (fan deck)

$$
47,048 \mathrm{ft}^{2} \times \$ 1.44^{(\mathrm{c})} \times 1.21^{(\mathrm{b})}=\frac{81,976}{\$ 1,123,786}
$$

\footnotetext{
(a) An average for rolled sections, columns, beams and girders, A-36 steel, shop primed, two field coats, bolted connections. Include shop fabrication and delivery.

(b) 10 percent overhead and 10 percent markup

(c) Galvanized metal decking, 20 gage, corrugated
} 
Foundation Costs

Site grading and compaction

$$
1900 \mathrm{yd}^{3} \text { o } \$ 2.70 / y \mathrm{~d}^{3}
$$

$$
=\$ 5,130
$$

Disposal

$$
760 \mathrm{yd}^{3} \text { @ } \$ 2.38 / \mathrm{yd}^{3}
$$

$$
\begin{aligned}
& =\quad 1,808 \\
& =\quad 6,375
\end{aligned}
$$

Structure excavation

$$
1700 y d^{3} \text { o } \$ 3.75 / y d^{3}
$$

Structure backfill

$$
1600 y d^{3} \text { a } \$ 4.70 / y d^{3}
$$

$=7,520$

Footings

$$
4040 \mathrm{ft}^{2} \text { a } \$ 2.28 / f \mathrm{t}^{2}
$$

$$
=9,211
$$

Concrete

$$
170 \mathrm{yd}^{3} 0 \$ 60.23 / \mathrm{yd}^{3}=10,239
$$

Re-bar

$$
13 \text { tons o } \$ 1172.03 / \text { ton }=15,236
$$

Six-inch thick compacted graded gravel layer on and around base

$$
\begin{array}{rr}
2,330 \mathrm{yd}^{3} \mathrm{\$} \$ 16.57 / \mathrm{yd}^{3} & =\frac{\$ 38,608}{\text { SUBTOTAL }} \\
\text { 10\% OVERHEAD + 10\% MARKUP } & \frac{19,767}{94,128} \\
\text { TOTAL INSTALLED COST } & \$ 113,895 \\
\text { ROUND TO } & \$ 114,000
\end{array}
$$

\subsubsection{Circular Arrangement Cost Algorithms}

As with the rectangular case, it was desired to model the change of structure cost as a function of tube bundle length and bundle depth. Both would change the bundle weight. The base case cost of the steel portion of the structure is $\$ 14.45$ per $\mathrm{ft}^{2}$ of frontal area. It is also $\$ 0.2458$ per $\mathrm{ft}^{3}$ of tower volume.

Algorithm 1. There is no change in steel cost for a change in bundle weight. (There is, however, a change in foundation cost; see Algorithm 5.) 
Algorithm 2. A change in bundle length changes the structural steel cost in direct proportion to the change in length and hence to the change in structure volume. Therefore, new steel cost $=\$ 0.2458 \times$ new tower volume in $\mathrm{ft}^{3}$.

Algorithm 3. For variations in tower diameter, the steel structure cost is similarly a function of tower volume. Thus, new total steel cost $=$ tower volume in $\mathrm{ft}^{3} \times \$ 0.2458$.

Algorithm 4. For computing steel costs for changes in roof loading, the expression developed was: $c_{1}=\$ 0.2458 \vee\left(0.00305 w_{1}+0.878\right)$ in which:

$C_{1}=$ new structural steel cost

$V=$ building volume in $\mathrm{ft}^{3}$

$W_{1}=$ roof load in $1 \mathrm{~b} / \mathrm{ft}^{2}$

Algorithm 5. For a change in bundle weight or tower plan area, the foundation cost would change in proportion to the weight change and area change as follows: $C_{2}=\$ 0.019 \mathrm{~W}_{2}+\$ 0.82 \mathrm{~A}$ in which:

$C_{2}=$ new foundation cost

$W_{2}=$ new bundle weight ${ }^{(a)}$ in $1 b$

$A^{2}=$ new tower area in $\mathrm{ft}^{2}$.

\subsubsection{Algorithm Bases}

Algorithm 1 states that there is no change in the steel cost for a change in bundle weight. This is because the bundles are self-supporting. Large side channels on each bundle are sufficient to support the tube bundle and also the wind load. These channels are a part of the bundle and although they form a part of the structure, they are not included as a part of the structure cost. They were included in bundle costs.

Algorithm 2 establishes that the structure cost varies in proportion to the tower volume. For a high-rise structure with several levels of internal framing (e.g., roof level, intermediate bracing or framing levels) the structure cost is best represented by a cost per unit volume. This method accounts for costs of internal steel, both horizontal and vertical, that would not be properly accounted for by a cost per unit area or unit height.

(a) Bundle weight includes weight of water. 


\section{Algorithm 3 is a restatement of Algorithm 2 .}

Algorithm 4 was developed to cover the cost variations that would occur when the number of fans or snow loading is varied. For this algorithm, it was desired to calculate new structural steel costs when the roof load was varied from 20 psf to 60 psf. The 20 psf represents the minimum roof loading allowed by the Uniform Building Code.

The cost relationship shown in Table $7-3$ is similar to the one developed for horizontal towers, using column factors and framing factors from Reference 25. When the data from Table 7-3 are plotted and a curve is fitted so that it goes through the 40 psf cost, the equation $y=m x+b$ is $y=$ $0.00305 x+0.878$.

Algorithm 5 treats the foundation costs separately. For this relationship, the amount of foundation cost proportional to weight (size of footings, depth of footing excavation,) and the amount proportional to building area (site grading and compaction, gravel layer) were found to be about equal. The developed expression apportions the cost changes one-half for weight changes and one-half for area changes.

TABLE 7-3. Total Structural Steel costs of Two Towers (a)

\begin{tabular}{|c|c|c|c|c|c|c|c|}
\hline $\begin{array}{l}\text { Column } \\
\text { Factors } \\
\end{array}$ & $\begin{array}{l}\text { Framing } \\
\text { Factor } \\
\end{array}$ & $\begin{array}{l}\text { Load, } \\
\text { psff }\end{array}$ & $\begin{array}{l}\text { Column } \\
\text { Cost, } \$\end{array}$ & $\begin{array}{l}\text { Framing } \\
\text { Cost, } \$\end{array}$ & $\begin{array}{l}\text { Unaffected } \\
\text { Cost, } \$\end{array}$ & $\begin{array}{c}\text { Total } \\
\text { Cost, } \$ \\
\end{array}$ & $\begin{array}{r}\text { Cost } \\
\$ / \mathrm{ft}^{3} \\
\end{array}$ \\
\hline 0.89 & 0.85 & 20 & 169,545 & 269,875 & 615,786 & 1,055,296 & 0.2308 \\
\hline 1.0 & 1.0 & 40 & 190,500 & 317,500 & 615,786 & $1,123,786$ & 0.2458 \\
\hline 1.11 & 1.15 & 60 & 211,455 & 365,125 & 615,786 & $1,192,366$ & 0.2608 \\
\hline
\end{tabular}

(a) Amount of steel as columns $=300,000 \mathrm{lb}$ Amount of steel as roof framing $=500,000 \mathrm{lb}$ Amount of steel not affected (Bracing, intermediate leve 1 beams, stairs, base plates, etc.) 


\subsection{WATER QUALITY CONTROL}

In this section the costs of water quality control will be compared for three potential dry cooling systems:

- the separate wet/dry system, in which the cooling capability of the dry cooling tower is augmented by a completely separate evaporative cooling tower;

- the combined wet/dry system, in which the dry tower is in series with an evaporative cooling tower; and

- the deluged dry cooling system, in which the cooling capacity of the dry tower is augmented by deluging the fin-tube surfaces with water.

In each system, the water must be treated to prevent corrosion, scaling and/or fouling. The separate wet/dry system and the deluged system each utilize a closed recirculating loop to carry the cooling water from the condenser to the dry cooling tower. The water in this loop must be treated to lower the dissolved solids content, then deaerated and inhibited to prevent corrosion of the condenser, tower heat exchanger and piping.

The separate wet/dry and the combined wet/dry systems both involve the use of an evaporative cooling tower. These are open recirculating loops. The water treatment is similar to that of a conventional cooling tower--sidestream treatment plus inhibition and chlorination for scaling and biofouling control.

The delugate loop in the deluged dry cooling system is similar in many respects to an open evaporative system, but the fact that the delugate is turned off and allowed to evaporate on the fin surfaces periodically necessitates a unique water treatment methodology. Side-stream treatment and $\mathrm{pH}$ control with sulfuric acid are specified, primarily for control of calcium carbonate scale. This system is discussed in detail in Reference 26.

\subsection{SEPARATE WET/DRY SYSTEM}

A simplified diagram of the separate wet/dry system is shown in Figure 8-1. 


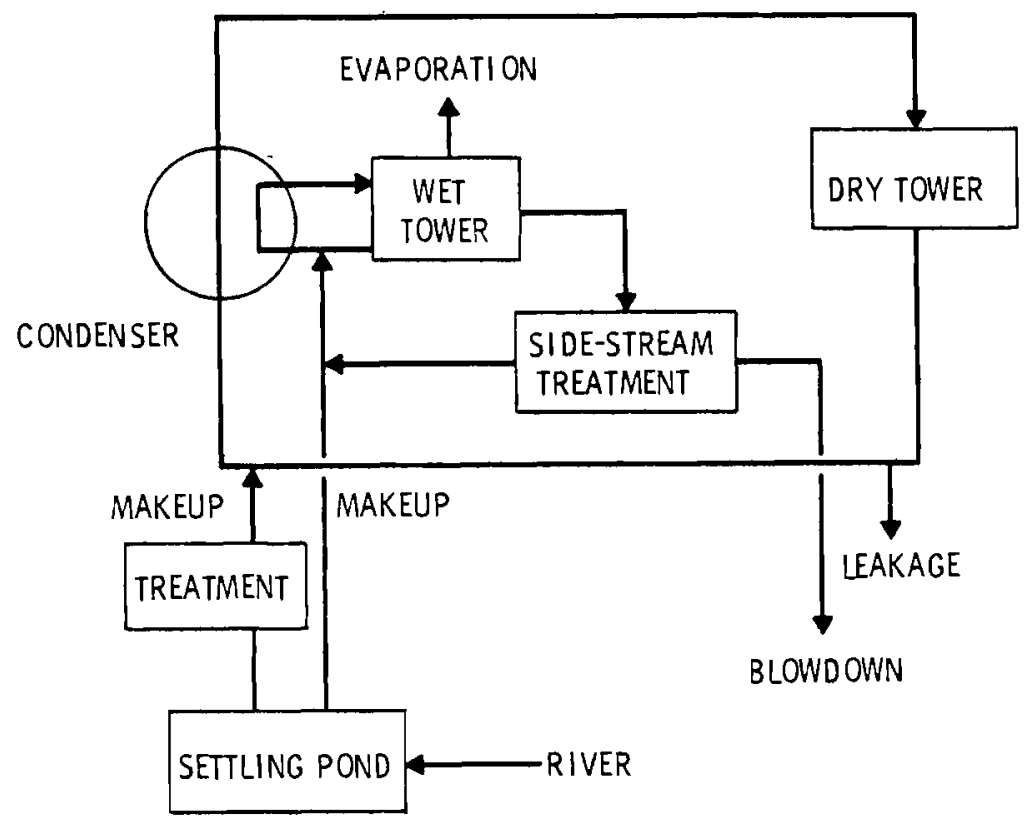

FIGURE 8-1. Separate Wet/Dry Cooling System

\subsubsection{Dry Loop - Closed Recirculating System}

The water circulating from the condenser to the dry tower must be treated, deaerated, and inhibited to prevent corrosion of the condenser and piping. Assumptions upon which cost analyses are based are given in Table 8-1.

TABLE 8-1. Bases for Closed Recirculating System Water Treatment Costs Condenser Material: Admiral ty

Piping and DCT Tubing Material: Carbon Steel

Sys tem Volume:

$1.6 \times 10^{6}$ gallons

Flow Rate:

$2.19 \times 10^{5} \mathrm{gpm}$

Water Quality:

Total Hardness, $\mathrm{mg} / \mathrm{l}$ as $\mathrm{CaCO}_{3}$

Makeup

Calcium Hardness, $\mathrm{mg} / \mathrm{l}$ as $\mathrm{CaCO}_{3}$

220

165

235

175

390

Recirculating

Total Alkalinity, $\mathrm{mg} / \mathrm{l}$ as $\mathrm{CaCO}_{3}$

Sulfate, $\mathrm{mg} / \mathrm{l}$ as $\mathrm{CaCO}_{3}$ 


\subsubsection{Demineralization Plant}

The water treatment plant is a demineralization unit sized at 60,000 gallons/day; this will give an initial system-fill time of about one month. The plant will be capable of providing treated makeup water to the system at a rate of about 42 gallons/min. This is about four times the expected leak rate.

The capital cost (1975 doliars) of such a treatment plant is estimated to be $\$ 172,000$ instailed, not including land and building costs. Also, it, is assumed that a settiing pond is available to remove suspended solids; cost of this pond is not included in the total. Breakdown of these costs is given in Table 8-2.

The cost of operating the demineralization plant is estimated to be $\$ 0.588$ per 1000 galions of water treated, or about $\$ 10,000$ per year, assuming the plant operates at 80 percent of capacity. The operating cost breakdown is given in Table 8-3.

\section{TABLE 8-2. Water Treatment Capital Costs, Closed Recirculating System}

\section{Component}

Intake structures

Forwarding pumps and piping

Weak acid cation exchangers

Cation exchangers, incl. $\mathrm{H}_{2} \mathrm{SO}_{4}$ storage

Decarbonator

Anion exchangers, incl. $\mathrm{NaOH}$ storage

Wastewater neutralization

Product water storage

Product water pumps and piping

Miscellaneous parts
Cost (instalied)

$\$ 6,000$

3,000

42,000

40,000

10,000

45,000

6,000

10,000

3,000

7,000

Total

$\$ 172,000$ 
TABLE 8-3. Water Treatment Operating Costs, Closed Recirculating System

Cost, $\$ / 1000$ gallons

Chemical

Sulfuric acid o $\$ 50 /$ ton

Sodium hydroxide o $\$ 10 / 100$ lbs

Electrical o $\$ 0.01 / \mathrm{kWh}$

Pumping

0.015

Other electrical

0.008

Materials

Resin replacement

0.030

Other

0.021

Labor a \$10/hour

Operation and maintenance

0.119

Chemist and other labor

0.100

$\begin{array}{rr}\text { Total } & \$ \overline{\$ 0.588} \\ \text { Yearly Cost } & \$ 10,000.00\end{array}$

\subsubsection{Deaeration}

Because the recirculating water is relatively $\operatorname{cool}\left(60^{\circ} \mathrm{C}\right)$, vacuum deaeration must be employed to reduce oxygen content to acceptable levels. The most economical vacuum-producing equipment is the steam ejector or steamjet evacuator. Figure 8-2 shows an ejector system similar to that needed for this application. (27) Estimated capital cost of this equipment for the system described here is $\$ 40,000$ installed. Operating cost is estimated at $\$ 5,000$ per year, not including steam cost.

\subsubsection{Corrosion Inhibition}

By far, the best inhibitors for use in this system are those containing chromates; however, the use of such inhibitors must be ruled out on the basis of discharge regulations. Inhibitors containing boron must be discarded as candidates for the same reason. The only inhibitor which can be considered 


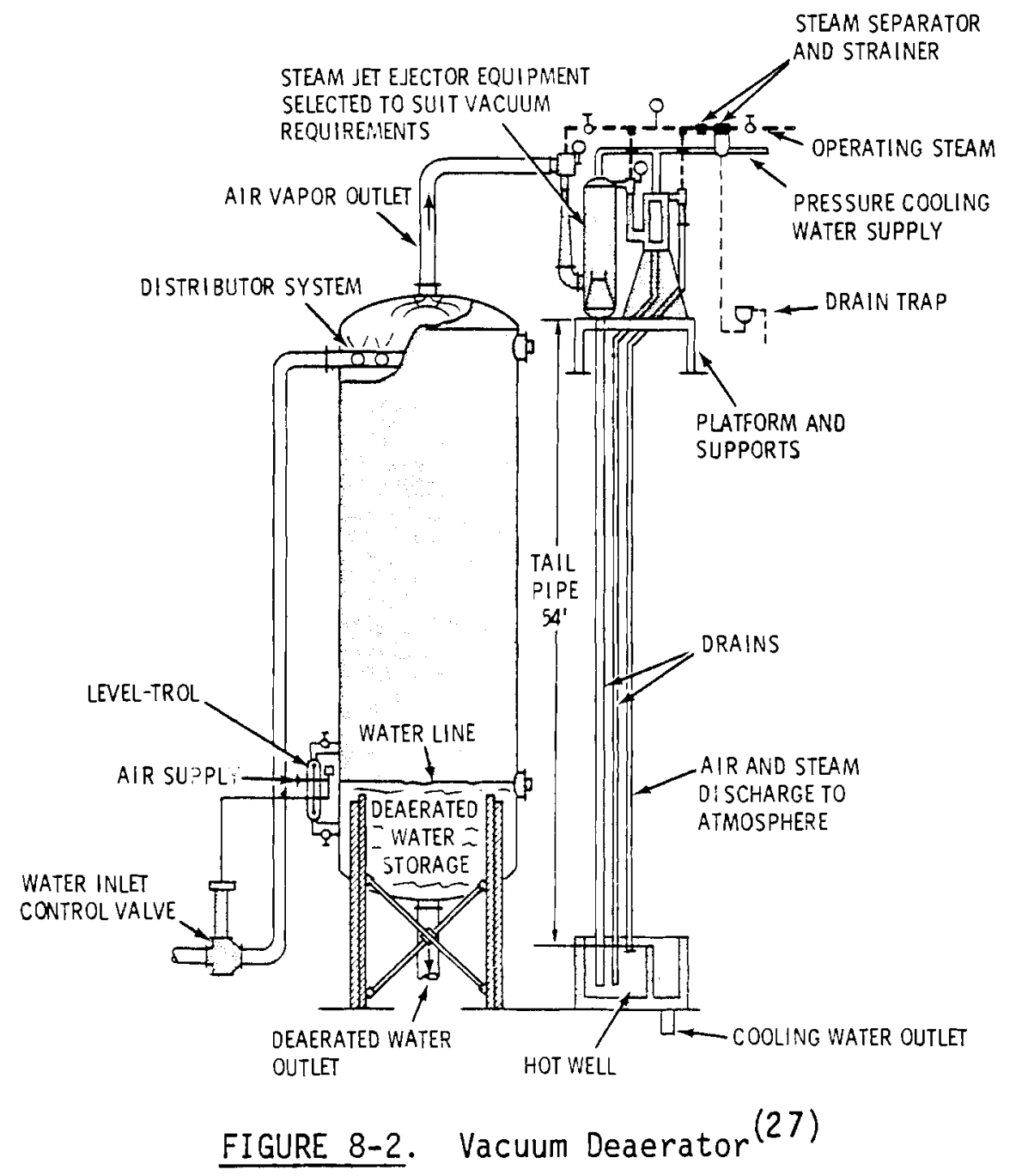

is one using nitrite and silicate as the major constituents. An inhibitor containing 85 percent sodium nitrite $\left(\mathrm{NaNO}_{2}\right)$ and 15 percent sodium metasilicate $\left(\mathrm{NaSiO}_{3}\right)$ is recommended. The inhibitor should be dosed to a level of about $700-900 \mathrm{mg} / \mathrm{l}$ nitrite. An inhibitor with the above composition is commercially available in 450 -pound drums for $\$ 0.55$ to $\$ 0.63$ per pound. The $\mathrm{pH}$ should be maintained at about 8.5 with sulfuric acid or sodium bisulfate. Total capital cost of the system for corrosion inhibition is estimated at $\$ 35,000$; operating cost is about $\$ 41,000$ per year.

\subsubsection{Total Water Treatment Costs, Wet/Dry Closed Recirculating System}

The total water treatment costs for this system are summarized in Table 8-4. 
TABLE 8-4. Summary of Water Treatment Costs, Closed Recirculating Sys tem

\begin{tabular}{|c|c|c|}
\hline Treatment & Capital Cost & Annual Operating cost \\
\hline Demineralization & $\$ 172,000$ & $\$ 10,000$ \\
\hline Deaeration & 40,000 & 5,000 \\
\hline Corrosion Inhibition & 35,000 & 41,000 \\
\hline Total & $\$ 247,000$ & $\$ 56,000$ \\
\hline
\end{tabular}

\subsubsection{Wet Loop - Conventional Evaporative Cooling}

The water in the open recirculating system to the wet cooling tower must be treated and inhibited for scale and biofouling control. Assumptions upon which cost analyses are based are given in Table 8-5.

TABLE 8-5. Bases for Open Recirculating System Water Treatment costs

Flow Rate:

$$
1.0 \times 10^{5} \mathrm{gallons} / \mathrm{min}
$$

System Volume: $\quad 8.0 \times 10^{5}$ gallons

Evaporation Rate: $4.0 \times 10^{3} \mathrm{gallons} / \mathrm{min}$ Water Quality:

Makeup

Total Hardness, $\mathrm{mg} / \mathrm{l}$ as $\mathrm{CaCO}_{3}$

Calcium, $\mathrm{mg} / \mathrm{l}$ as $\mathrm{CaCO}_{3}$

Total Alkalinity, $\mathrm{mg} / \mathrm{l}$ as $\mathrm{CaCO}_{3}$

Chloride, $\mathrm{mg} / \mathrm{l}$ as $\mathrm{CaCO}_{3}$

Sulfate, $\mathrm{mg} / \mathrm{l}$ as $\mathrm{CaCO}_{3}$

Total Dissolved Solids, $\mathrm{mg} / \mathrm{l}$
220

165

235

150

175

390
Recirculating

1,100 780 300 6,000 10,000 24,000

A simplified diagram of the treatment system for the wet cooling tower is shown in Figure 8-3.

Side-stream treatment of the recirculating cooling water is chosen to minimize water use and solve problems of waste disposal while maintaining a water quality which promotes efficient and economical operation of the cooling system. The treatment system shown operates with alkaline recirculating water containing an appropriate scale inhibitor because the total sulfate and 


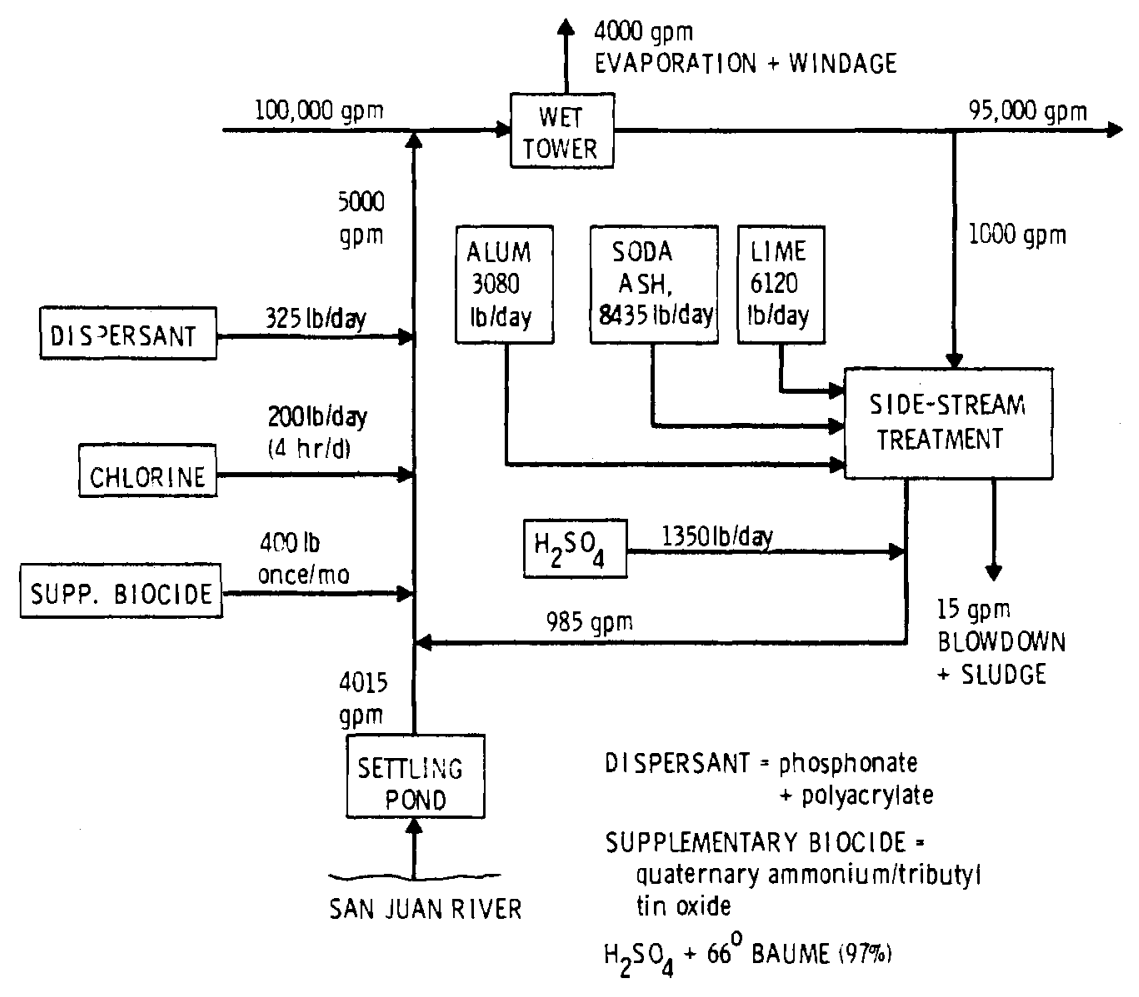

FIGURE 8-3. Treatment of Wet Tower Loop Water, Separate Wet/Dry System

chloride content of the makeup after acid neutralization for operation at low $\mathrm{pH}$ would limit the effectiveness of the side-stream treatment.

The capital cost of this treatment system is broken down in Table 8-6. Total estimated capital cost is $\$ 410,000$.

Operating costs of treating this open recirculating system are shown in Table 8-7. Yearly operating cost is estimated at $\$ 490,000$.

\section{TABLE 8-6. Estimated Capital Costs of Water Treatment, Wet Tower Loop Water}

\section{Component}

Side-stream treatment

Scale inhibition

Biofouling control
Installed Cost

$\$ 300,000$

97,000

12,000

Tota 1

$\$ 409,000$ 
TABLE 8-7. Operating Cost for Open Recirculating System Water Treatment

\begin{tabular}{|c|c|c|c|}
\hline Item & Cost/Unit & Amount Needed & Cost/Day \\
\hline Lime & $\$ 0.017 / 1 \mathrm{~b}$ & $61201 \mathrm{~b} /$ day & $\$ 104.04$ \\
\hline Soda Ash & $\$ 0.03 / 1 \mathrm{~b}$ & $84351 \mathrm{~b} /$ day & 253.05 \\
\hline Alum & $\$ 0.20 / 1 b$ & $30801 \mathrm{~b} /$ day & 616.00 \\
\hline Dispersant & $\$ 0.78 / 1 \mathrm{~b}$ & $3251 \mathrm{~b} /$ day & 253.50 \\
\hline Chlorine & $\$ 0.10 / 1 b$ & 200 1b/day & 20.00 \\
\hline Supp. Biocide & $\$ 1.92 / 1 \mathrm{~b}$ & $400 \mathrm{lb} / \mathrm{mo}$ & 25.60 \\
\hline Sulfuric Acid & $\$ 0.03 / 1 \mathrm{~b}$ & 1350 1b/day & 40.50 \\
\hline Labor & $\$ 10 /$ man-hr & 32 man-hr & 320.00 \\
\hline Electricity & $\$ 0.01 / \mathrm{kWh}$ & $3500 \mathrm{kWh} /$ day & 35.00 \\
\hline \multicolumn{3}{|c|}{ Total Daily Cost } & $\$ 1,667.69$ \\
\hline \multicolumn{3}{|c|}{ Total Yearly Operating Cost ( $80 \%$ Capacity) } & $\$ 487,000.00$ \\
\hline
\end{tabular}

\subsection{COMBINED WET/DRY SYSTEM}

A simplified diagram of the combined wet/dry system is shown in Figure 8-4.

Because the system is open, the water treatment system and costs are essentially the same as for the wet (open) loop of the separate wet/dry system. Capital and operating costs are itemized in Tables 8-6 and 8-7.

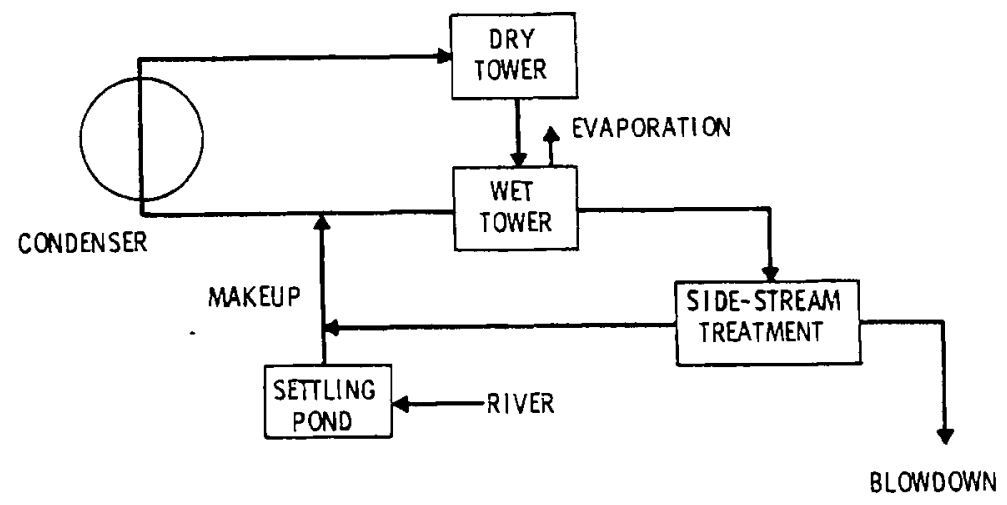

FIGURE 8-4. Combined Wet/Dry Cooling Sys tem 


\subsection{CLOSED RECIRCULATING DRY SYSTEM, DELUGED}

This cooling system consists of two separate water loops: a closed recirculation system similar to that discussed in Section 8.1.1, and an open system which supplies water for deluging the finned heat exchanger surfaces during warm periods of the year. In addition, about 50,000 gallons of zerohardness water are needed to flush the fin surfaces each time the delugate flow is turned off ( $\sim$ once per day). A simplified diagram of this system is shown in Figure 8-5.

\subsubsection{Dry Loop - Closed Recirculating System}

This system is identical to that discussed in Section 8.1.1. Capital and operating costs are summarized in Tables 8-2 and 8-3.

\subsubsection{Delugate Loop - Open Recirculating System}

This system is similar in many ways to a conventional evaporative cooling system as discussed in Section 8.1.2, but it differs in several important respects. The delugate must be treated for scale control, but the water is controlled at a lower $\mathrm{pH}$ than the evaporative cooling water because dispersants cannot be used. Also, there is no biofouling control in this system; it is assumed that biofouling will be controlled by the alternate wetting and drying cycles of the system. Assumptions upon which the cost analyses are based are given in Table 8-8.

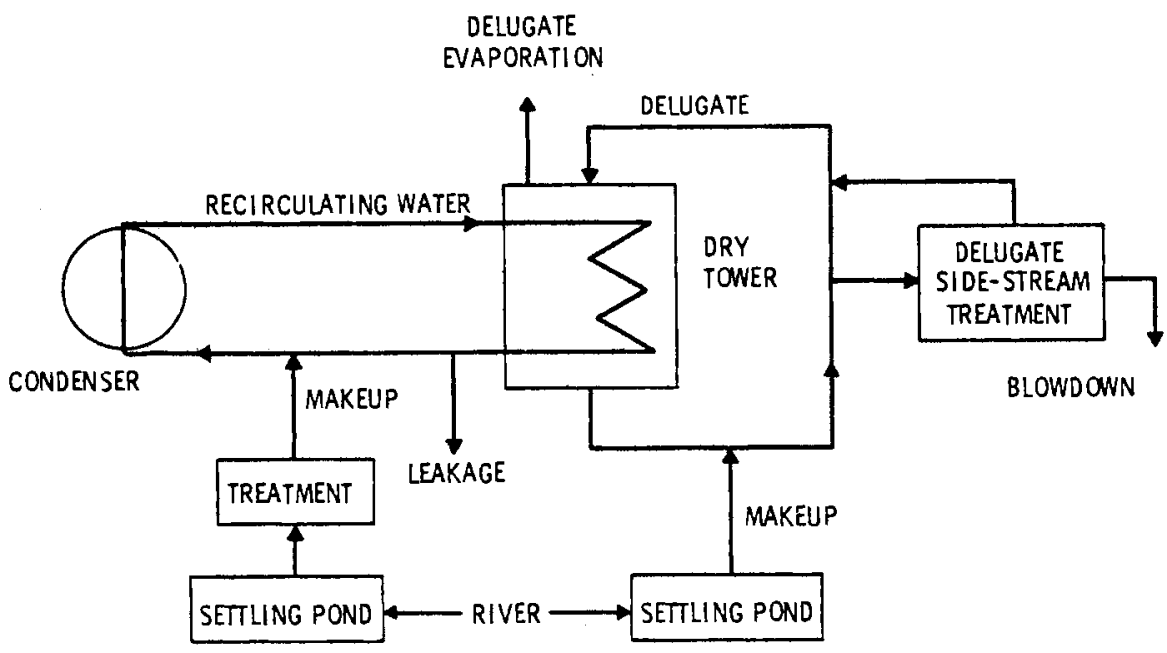

FIGURE 8-5. Closed Recirculating Dry System, Deluged 
TABLE 8-8. Bases for Delugate Water Treatment Costs

Flow Rate: $\quad 2.1 \times 10^{4}$ gallons $/$ min

Volume: $\quad 3.0 \times 10^{5} \mathrm{gallons}$

Evaporation Rate: $4.0 \times 10^{3}$ gallons/min

\section{Water Quality:}

Total Hardness, $\mathrm{mg} / \mathrm{l}$ as $\mathrm{CaCO}_{3}$

Calcium, $\mathrm{mg} / \mathrm{l}$ as $\mathrm{CaCO}_{3}$

Total Alkalinity, $\mathrm{mg} / \mathrm{l}$ as $\mathrm{CaCO}_{3}$

Chloride, $\mathrm{mg} / \mathrm{l}$ as $\mathrm{CaCO}_{3}$

Sulfate, $\mathrm{mg} / \ell$ as $\mathrm{CaCO}_{3}$

Total Dissolved Solids, $\mathrm{mg} / \ell$
Makeup

220

165

235

150

115

390
Recirculating

1,325

950

40

10,000

7,800

40,000

A simplified diagram of the treatment system for the delugate is shown in Figure 8-6.

The capital cost of this treatment system is broken down in Table 8-9. Total estimated capital cost is $\$ 110,000$.

Operating costs. of treating the delugate are shown in Table 8-10. Yearly operating cost is estimated at $\$ 107,000$.

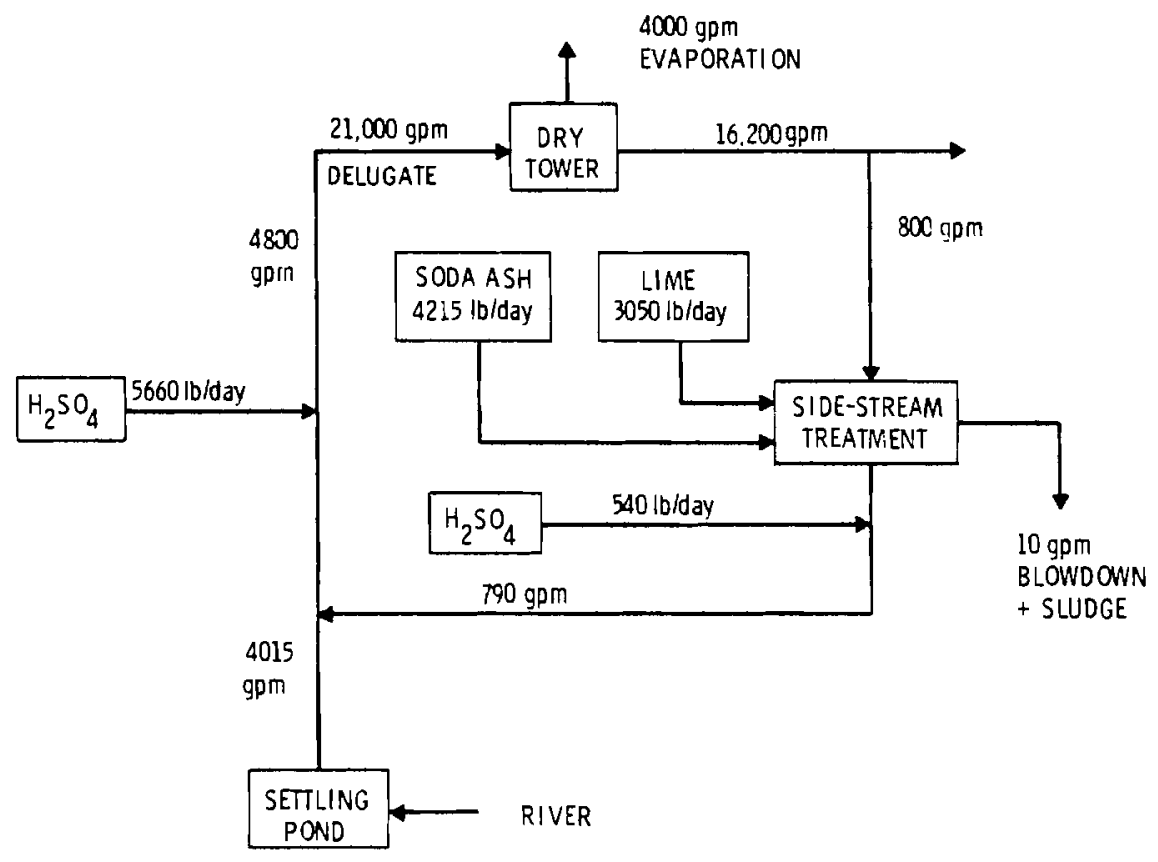

FIGURE 8-6. De lugate Treatment 
TABLE 8-9. Estimated Capital Costs of Delugate Treatment

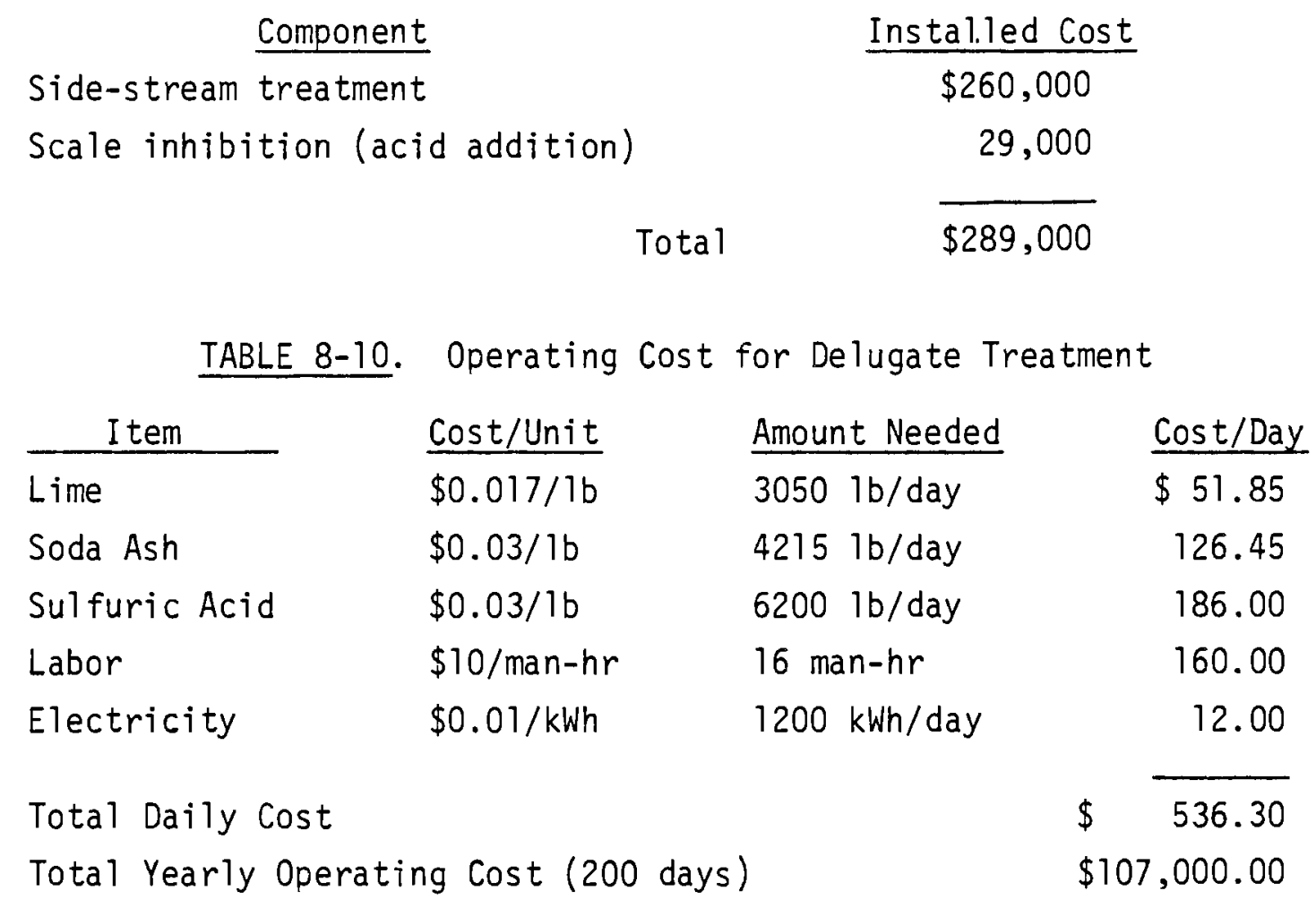

\subsubsection{Zero-Hardness Flush Water}

Estimated capital cost of a sodium zeolite water treatment system to produce 50,000 gallons per day of zero-hardness water is $\$ 150,000$ installed. Yearly operating cost will be about $\$ 4000$.

\subsection{SUMMARY OF WATER TREATMENT COSTS}

A summary of the water treatment costs for the alternative cooling tower systems is given in Table 8-11. 
TABLE 8-11. Summary of Water Treatment Costs for Alternative Cooling Tower Systems

Total Capital Costs, \$
Total Operating Costs, $\$ / y r$

System

Separate Wet/Dry

a) Closed Recirculating System

1. Demineralization Plant

$\$ 172,000$

$\$ 10,000$

2. Vacuum Deaeration

40,000

5,000

3. Corrosion Inhibition

35,000

41,000

b) Open Recirculating System

1. Side-stream Treatment

2. Scale Inhibition

300,000

487,000

3. Biofouling Control

97,000

12,000

Total Cost

$\$ 656,000$

$\$ 543,000$

Combined Wet/Dry

a) Side-stream Treatment

$\$ 300,000$

$\$ 487,000$

b) Scale Inhibition

97,000

C) Biofouling Control

12,000

Total Cost

$\$ 409,000$

$\$ 487,000$

Deluged System

a) Closed Recirculating System

1. Demineralization Plant

2. Vacuum Deaeration

$\$ 172,000$

$\$ 10,000$

40,000

5,000

3. Corrosion Inhibition

35,000

41,000

b) Open Recirculating System

1. Side-stream Treatment

260,000

107,000

2. Scale Inhibition

29,000

c) Flush Water

1. Sodium Zeolite Softening

150,000

4,000

Total Cost

$\$ 686,000$

$\$ 167,000$ 


\subsection{COOLING TOWER ELECTRICAL SYSTEM}

The electrical system estimates are applicable to mechanical draft aircooled plants from about 250 through 1000 MWe. The electrical system is divided into four basic subsystems:

- fan motor electrical system,

- pump motor electrical system,

- lighting and small service power system, and

- intrumentation.

Electrical power for heat tracing of pipes and tanks has not been included. The greatest portion of the power in a mechanical draft cooling system is used by the fans, followed by the circulation system water pumps. These two motor power systems are treated together for costing purposes. The other two systems are treated separately.

\subsection{FAN AND PUMP ELECTRICAL POWER SYSTEMS}

The fan and pump motor power and control systems were costed by evaluating seven electrical system concepts supplying 5600 (two cases), 11,200, $12,800,19,200$ and 24,000 (two cases) horsepower. The cost of the entire central plant electrical system, which supplies all the plant equipment, was estimated and prorated according to the expected portion of the power absorbed by the cooling tower system. With mechanical draft systems, this is expected to range from 50 percent to 75 percent. A mean of 62.5 percent was used for this costing. The plant-associated electrical system costs include the equipment and installation of the primary transformers, main switchgear, 300 feet of interconnecting cable and duct, and a switchgear building.

The motor-associated portion of the system costs includes equipment and installation beyond the main plant switchgear such as cable and duct to the secondary transformers, secondary transformers, cable and duct to the motors, control cable and duct to the central plant control panel, and two buildings for the motor switchgear. The costs of the motors are not included in the electrical system costs but are included in the costs of the fan and 
circulation systems. A material and labor cost breakdown is presented in Appendix $J$ for each of the seven cases evaluated. A typical electrical system diagram for 19,200 hp is shown in Figure 9-1. A summary of the motor-associated costs and the adjusted plant-associated costs is given in Table 9-1 along with the unit costs per horsepower for the total system. A plot of the unit costs $(\$ / h p)$ for the total system versus motor size is given in Figure 9-2. This plot shows a very substantial decrease in costs per horsepower with increasing motor size, particularly up through 600-horsepower motors.

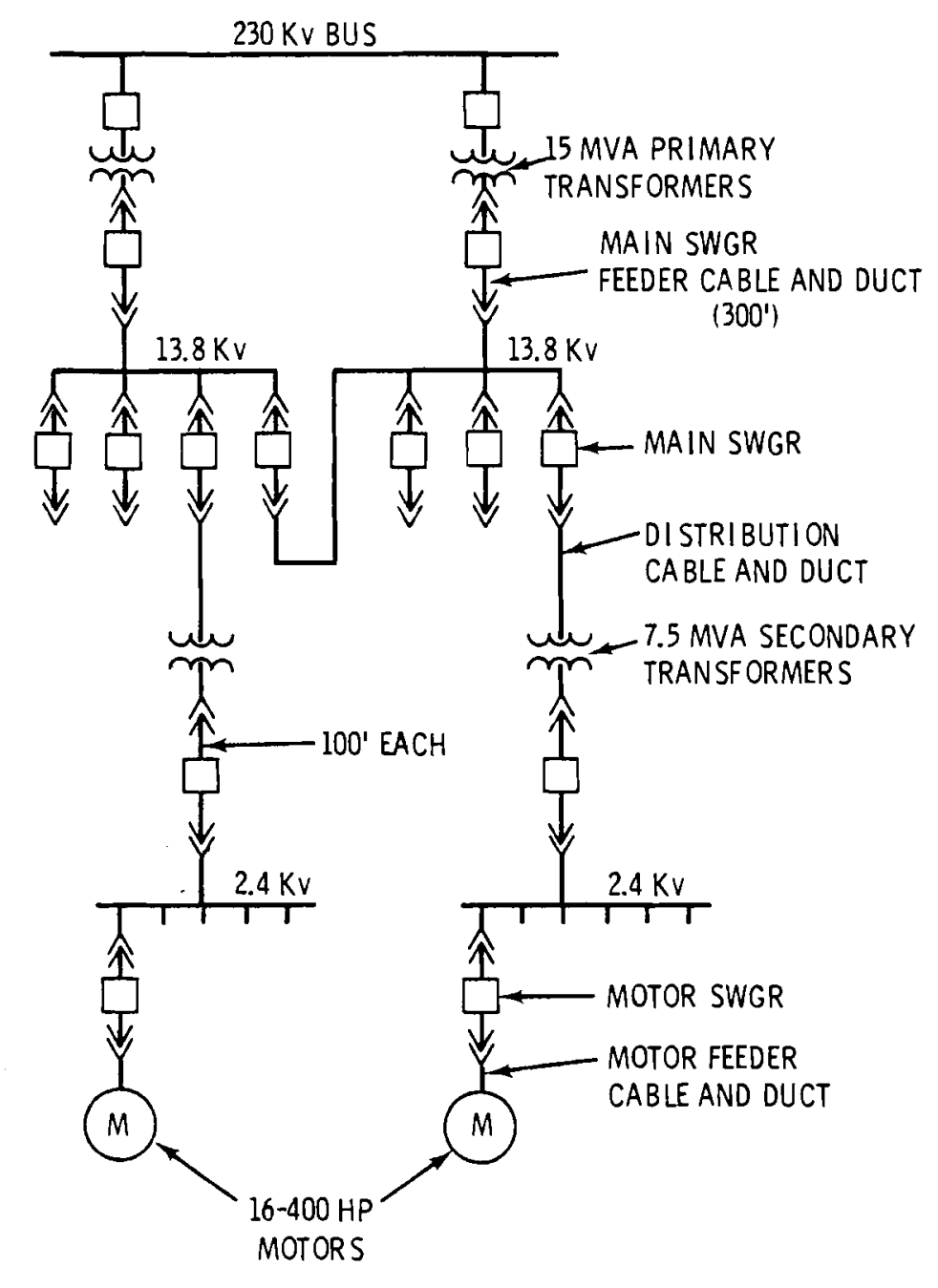

\subsection{HP SYSTEM}

FIGURE 9-1. One Cooling Tower Electrical System Used for costing 


$$
\text { 害言| }
$$

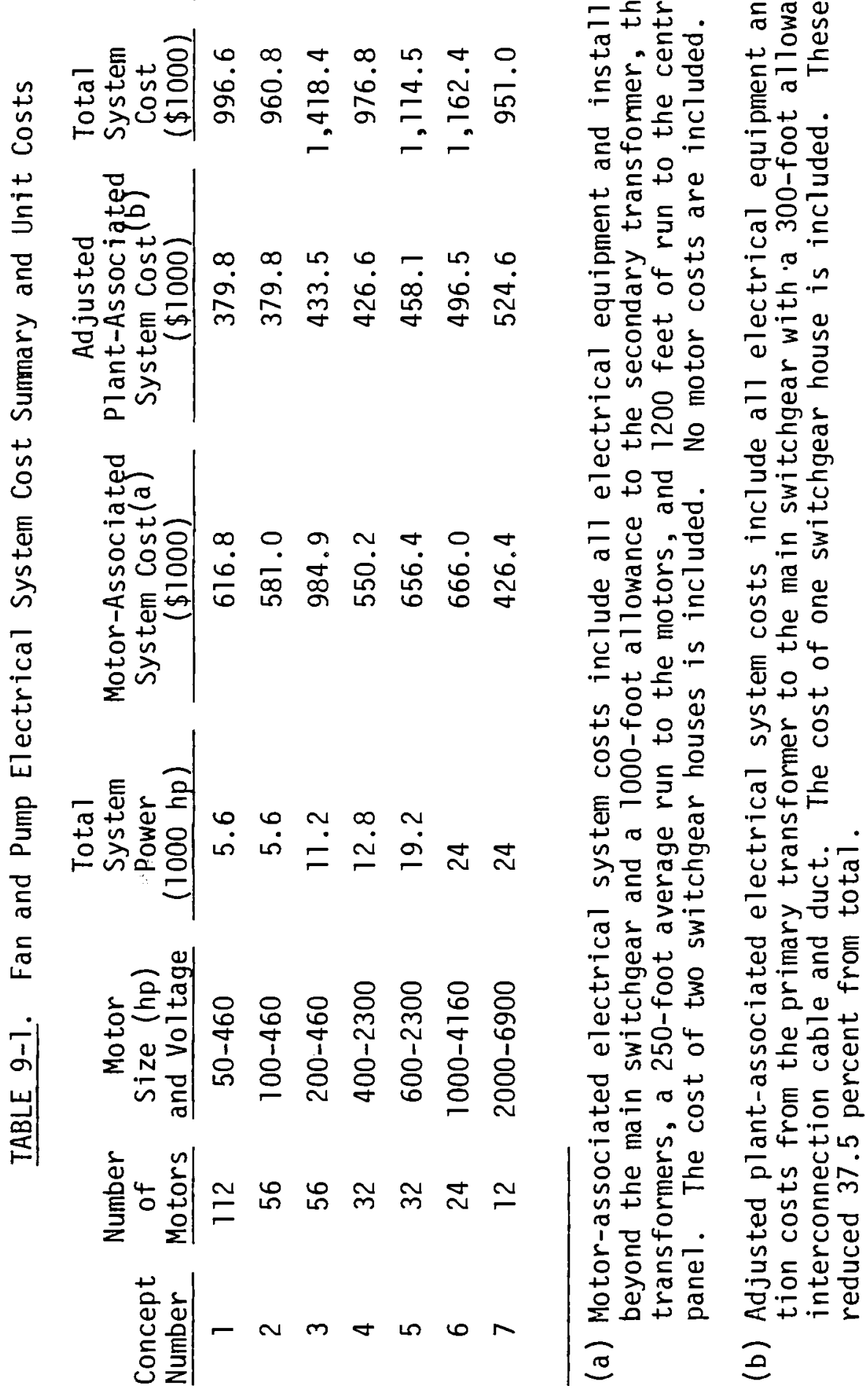




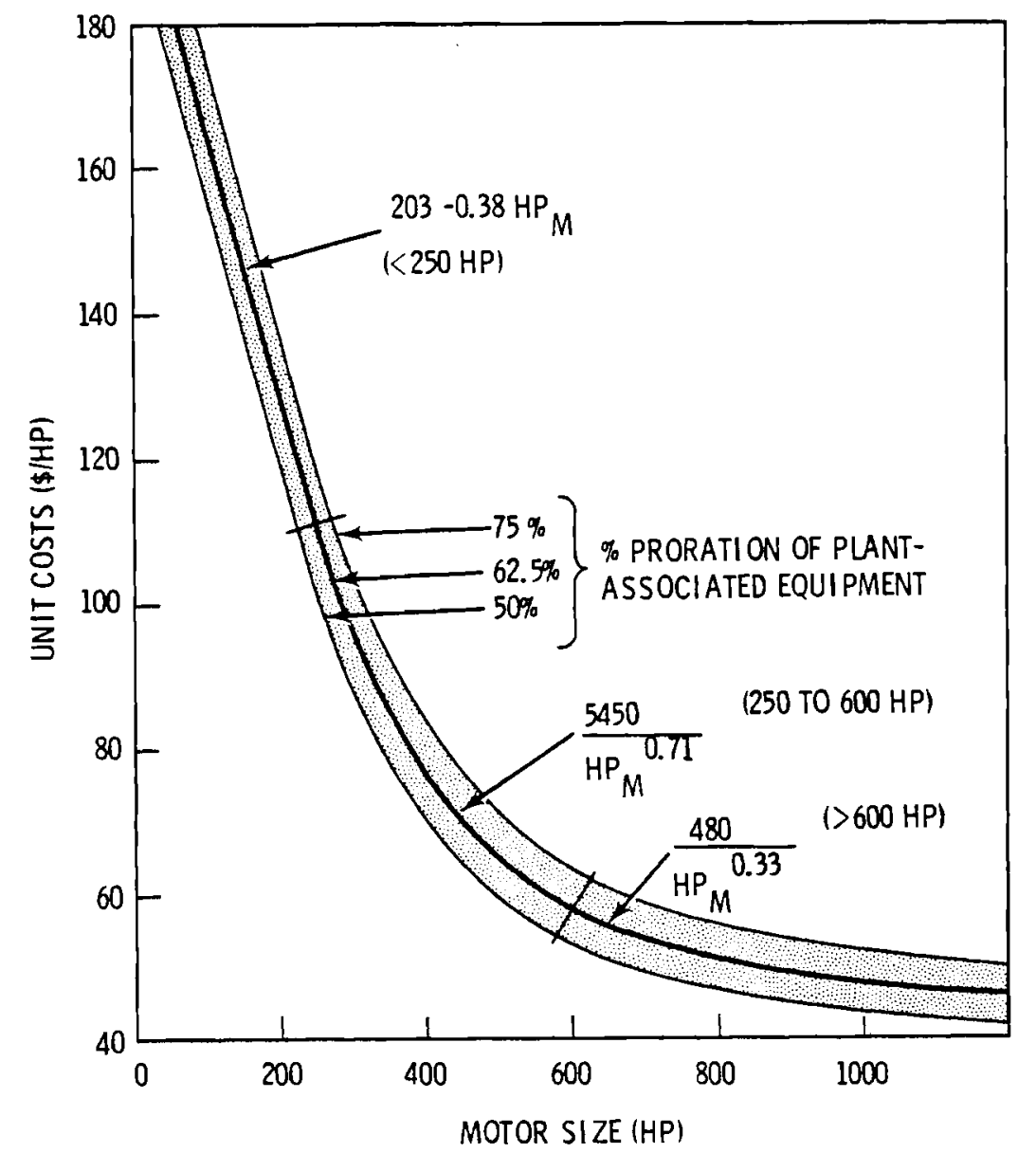

FIGURE 9-2. Fan and Pump Electrical and Control System Costs

Using the unit cost plot in Figure 9-2, cost relations were developed that would allow costing the electrical system for different motor sizes. These algorithms should apply with reasonable accuracy for electrical systems suppling 5000 to 25,000 horsepower using motors of from 25 to 2000 horsepower. Following are the cost algorithms with the performing subcontractor's burden and overhead of 14 percent and profit of 10 percent.

For motors of 25 through $250 \mathrm{hp}$,

$$
\left.C_{m s}=\sum_{H P}^{H P_{m}}=250\left[{ }^{\prime} 203-0.38 H_{m}\right) H P_{m} \cdot N_{m}\right] 1.25
$$


For motors of 251 through $600 \mathrm{hp}$,

$$
C_{m s}=\sum_{H P_{m}}^{H P_{m}}=600 \quad\left[\left(\frac{5450}{H P_{m} 0.71}\right) H P_{m} \cdot N_{m}\right] 1.25
$$

For motors of 601 through $2000 \mathrm{hp}$,

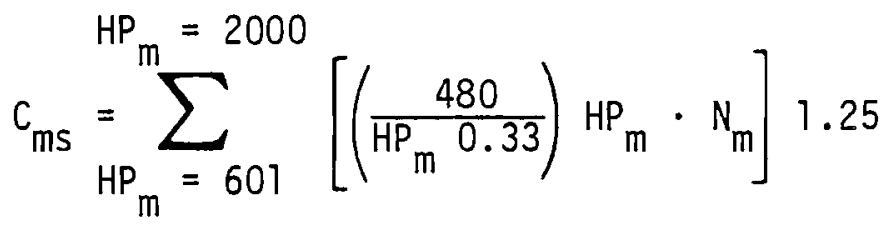

$$
\begin{aligned}
& C_{m s}=\text { motor electrical system cost }(\$) \\
& \mathrm{HP}_{\mathrm{m}}=\text { motor size (horsepower) } \\
& N_{m}=\text { number of motors of each size }
\end{aligned}
$$

$1.25=$ cost factor for contractors overhead and burden.

Using the above expressions, costs of the motor electrical system versus total system power were developed. These costs are plotted for 100-, 200-, and 400-horsepower motors in Figure 9-3.

In all seven cases, the cost evaluations were based on the secondary transformers or motor switchgear being located 1000 feet from the plant switchgear and the motors being located 250 feet from the motor switchgear. Correction terms were developed to provide cost corrections for systems with other distances. Correction values from the following terms are added directly to the total system costs.

Distribution and control cables and ducts (main switchgear to secondary transformer other than 1000 feet)

$$
\Delta C_{m s}=\left(D_{D}-1000\right)\left(37+\frac{0.470 H P_{s}}{\sqrt{V_{D}}}+0.5 N_{m s}\right) 1.25
$$




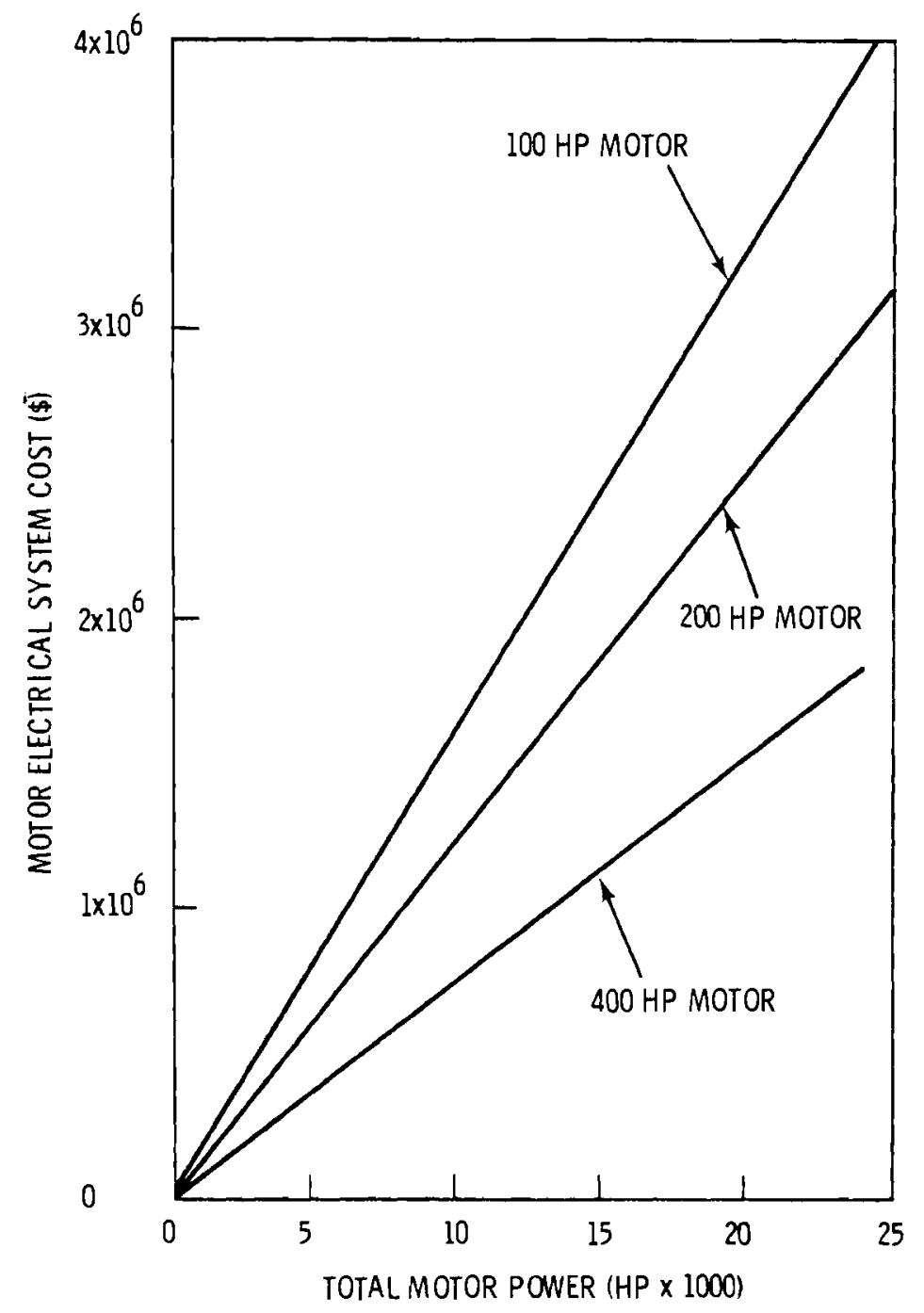

FIGURE 9-3. Motor Electrical System Costs Using Cost Algorithms

Motor feeder cables and ducts (motor switchgear to motor other than 250 feet)

$$
\begin{aligned}
& \Delta C_{\mathrm{ms}}{ }^{-}=\sum\left[\left(D_{M}-250\right) \frac{100+1.1 \mathrm{HP}}{\sqrt{V_{m}}} N_{m}\right] 1.25 \\
& \Delta C_{m s}=\text { electrical system cost correction (\$) for distribution and } \\
& \Delta C_{m s}=\text { electrical system cost correction }(\$) \text { for motor feeder } 1 \text { ine } \\
& 1.25 \text { = cost factor for contractor's burden, overhead and profit }
\end{aligned}
$$




$$
\begin{aligned}
D_{D}= & \text { distance from plant to secondary transformers or motor } \\
& \text { switchgear }(\mathrm{ft}) \\
D_{M}= & \text { distance from motor switchgear to motors }(\mathrm{ft}) \\
H_{\mathrm{S}}= & \text { total horsepower of the system or portion being corrected } \\
\mathrm{N}_{\mathrm{ms}}= & \text { number of motors of all sizes in the system or portion } \\
& \text { being corrected } \\
H_{\mathrm{m}}= & \text { size of motor being corrected (horsepower) } \\
\mathrm{N}_{\mathrm{m}}= & \text { number of motors of each size being corrected } \\
\mathrm{V}_{\mathrm{D}}= & \text { voltage of distribution line } \\
= & 13.8 \mathrm{kV}<1750 \mathrm{HP} \text { motors } \\
= & 6.9 \mathrm{kV}>1750 \mathrm{HP} \text { motors } \\
V_{m}= & \text { voltage of motors } \\
= & 480 \mathrm{~V}=250 \mathrm{HP} \\
= & 2300 \mathrm{~V} 251-800 \mathrm{HP} \\
= & 4160 \mathrm{~V} 800-1750 \mathrm{HP} \\
= & 6900 \mathrm{~V}>1750 \mathrm{HP}
\end{aligned}
$$

Both $\Delta C_{m s}$ and $\Delta C_{m s}^{\prime}$ cost corrections can be applied if only a portion rather than the whole system is affected by the changed length of either the distribution line or motor feeder line. These correction terms base the adjustment on the power and the number of motors in the portion of the system affected.

\subsection{LIGHTING AND SERVICE OUTLETS}

This system consists of fixtures, wiring, and controls for lighting required in and around the towers, switchgear buildings, valve and pump pits, etc. It includes service wiring and controls for small pumps, ventilating fans, compressors, and standard outlet receptacles. Heating and ventilation of the switchgear buildings are included in the building costs. 
Costs for the lighting are considered a percentage of the motor power system costs for estimating. Based on five conceptual estimates prepared by Vitro Engineering, (28) this averaged about 2 percent of the motor power system costs, including material and labor. This value will be applied for this portion of the electrical system.

\subsection{INSTRUMENTATION}

Instrumentation for dry or wet/dry cooling towers with water as the coolant consists of water quality analyzers and recorders, water temperature and pressure measurement and recording equipment, water level and flow indicators, and use totalizers. Measurement and recording equipment is also required for air temperature, humidity and pressure, as well as wind velocity and direction. Position meters for control valves and air louvers are required. A microprocessor system is also included for data analysis. Conceptual design estimates ${ }^{(28)}$ indicated that the instrumentation as described above would cost approximately 12.5 percent of the motor electrical system costs, including both material and labor.

The ammonia cooling towers require ammonia analyzers and leak sensors. Sensors would be placed in the air exits of the heat exchangers and the pump and valve stations. Analyzers are required to analyze the ammonia for impurities and the steam condensate for ammonia. These have tentatively been estimated at about 15 percent of the electrical system costs. If the tower is a wet/dry or deluged tower, this would be in addition to the 12.5 percent for the water and air instrumentation. 


\subsection{CONSTRUCTION COSTS}

Both direct and indirect costs were considered in this analys is.

\subsection{DIRECT CONSTRUCTION COSTS}

A11 direct construction costs are considered as costs to the engineering firm or prime contractor who performs no work for his own account. It is assumed one or more general contractors will purchase the equipment and construct the tower, condenser, and circulation systems. The electrical system will be subcontracted by a general contractor. The direct installed costs include the costs of materials, shipping, construction labor and equipment, as well as all overheads, burdens and profits up through the general contractor(s).

The costs developed in Section 3.0 for the heat exchanger units are considered material costs f.o.b. the manufacturer's plant. These costs were developed from manufacturing cost models that have the payroll burdens and direct job-related overheads as part of the unit costs. The general plant overheads and the profits are added as separate factors. General overheads may range from 8 to 15 percent ${ }^{(29)}$ of the product costs. An overhead rate of 10 percent was selected. The profits for a job of this size would probably range from 1.0 to 15 percent; 10 percent was used. The costs used for the fan equipment costing in Section 4.0 are generally manufacturer's prices f.o.b. his plant. Therefore, no factors were added. The costs for the fan plenums and velocity recovery stacks were developed from manufacturing algorithms and thus were handled the same as the heat transfer bundles. The costs presented in Section 3.0 for the shutters and hail screens are installed costs less the contractor's overhead and burden. A factor of 6 percent of the manufacturer's cost was added to cover shipping.

The costs for the circulation system, structures, water quality control system, and the condenser were presented in previous sections as direct installed costs with the general contractor's profits and overheads included. The electrical system costs include the subcontractor's burdens, overheads, and profits. The combined burden and overhead was estimated at 14 percent of material, labor, and equipment, while a profit of 10 percent of the same was used. 
Costs developed previously for the heat exchanger units and the mechanical draft equipment did not include shipping and installation. A cost factor of 6 percent of the manufacturer's f.o.b. plant prices was used for shipping. Cost of handing and installation of the bundles was estimated at about 6 percent of the manufacturer's price. Cost of handling, assembling and installation of the mechanical draft equipment is estimated at 9 percent of the manufacturer's price.

A figure of 10 percent of the material, shipping, equipment, and installation labor costs was used for the general contractor burden and overhead costs. For the subcontracts, 5 percent was used for the general contractor's overhead and profit applied to the general contractor's subcontract costs.

A summary of cooling system cost factors is presented in Table 10-1.

\subsection{INDIRECT COSTS}

The indirect costs are generally defined as the costs of the engineering firm providing the engineering and construction management. The engineering and management costs consist of personnel salaries, fees, field expenses, overheads, and profits. These costs are estimated ${ }^{(30)}$ at about 20 percent of the total installed cost and can generally be divided as 10 percent for engineering and 10 percent for construction management.

\subsection{ESCALATION AND CONTINGENCIES}

No escalation or contingency factors have been developed in this analys is for the cooling tower system. Escalation would depend upon the proposed year $(s)$ of construction, while the contingency factor would probably fall within 20 to 30 percent. 
TABLE 10-1. Summary of Cooling System Direct Construction Cost Factors

\begin{tabular}{|c|c|c|c|c|c|c|}
\hline & Reference & General & tractor & Subcontractc & Mfgr & \\
\hline System Component & $\begin{array}{l}\text { Section } \\
\text { Number }\end{array}$ & $\begin{array}{l}\text { Burden and } \\
\text { Overhead }(\%)\end{array}$ & Profit $(\%)$ & $\begin{array}{l}\text { Burden and } \\
\text { Overhead }(\%)\end{array}$ & Profit $(\%)$ & Shipping $(\%)^{(a)}$ \\
\hline Heat Exchanger Unit & 3.0 & $10^{(A D)}$ & $10^{(\overline{A D})}$ & 10 (Mfgr) & $\overline{10(M f g r)}$ & $\left(12^{6} \mathrm{~S} / 1\right)$ \\
\hline Fans and Equipment & 4.0 & $10^{(A D)}$ & $10^{(A D)}$ & (CU) & $(\mathrm{CU})$ & $\left(15^{6} \mathrm{~S} / \mathrm{I}\right)$ \\
\hline Circulation System & 5.0 & $67 \%$ of labor & 10 & (CU) & (CU) & CK \\
\hline Condenser & 6.0 & $67 \%$ of labor & 10 & (CU) & (CU) & 14 \\
\hline Structures & 7.0 & 10 & 10 & (CU) & (CU) & (CU) \\
\hline $\begin{array}{l}\text { Water Quality } \\
\text { Control System }\end{array}$ & 8.0 & (CU) & (CU) & (CU) & $(\mathrm{CU})$ & (cU) \\
\hline
\end{tabular}

(a) Based on manufacturer's prices (actual or estimated).

Definitions: $A D$ - These factors added in this section, not included in cost presented in previous sections.

CU - Cost unknown, cost part of manufacturer's prices, or part of the unit or total cost valves used.

CK - Cost known but part of unit costs in algorithms.

S/I - Combined shipping and installation factor. 
. 


\section{REFERENCES}

1. U.S. ERDA Dry Cooling Tower Development Program Plan, Revision 1. BNWL-B-393, Battelle, Pacific Northwest Laboratories, Richland, WA 99352 , July 1975.

2. Engineering and Economic Evaluation of Wet/Dry Cooling Towers for Water Conservation. United Engineers and Constructors, Inc., Philadelphia, PA, JuTy 1976 .

3. J. P. Rossie, E. A. Cecil, and R. 0. Young, Cost Comparison of Dry-Type and Conventional Cooling Systems for Representative Nuclear Generating Plants. TID-26007, R. W. Beck and Associates, Denver, CO, March 1972.

4. B. C. Fryer, An Engineering and Cost Comparison of Three Different A11-Dry Cooling Systems. BNWL-2121, Battelle, Pacific Northwest Laboratories, Richland, WA 99352 , to be published.

5. E. G. Brush and W. L. Pearl, "Corrosion and Corrosion Product Release in Neutral Feedwater." Corrosion. 28: 129, 1972.

6. J. R. Myers and M. F. Obrecht, "Performance and Selection of Materials for Potable Hot Water Service." Mat. Prof. and Perf. 12: 17, 1973.

7. J. Draley and W. Ruther, "Aqueous Corrosion of Aluminum - Part 1, Behavior of 1100 Alloy." Corrosion. 12: 441, 1956.

8. G. Resch, "Neve Richwerte füv Kesselspeise and Kesselwasser-Ein Beitrag Zur Neufassurg 1972." VGB Kraftwerkstechnik, Mitteilungen der VGB. 52(5): 385, October 1972 .

9. E. Beynon, Corrosion Inhibition on Automotive Cooling Systems. Union Carbide Corporation, Tarrytown, NY, 1968.

10. B. J. Kelly, Practical Corrosion Control of Closed Hot and Chilled Water Recirculating Systems. Nalco Reprint 134, Naico Chemical Company, Chicago, IL.

11. H. L. Craig, Jr. and P. H. Woods, "Inhibition of Corrosion of the Hypereutectic Aluminum-Silicon Alloys in Antifreeze Solutions." Corrosion. 16: 129, 1960.

12. H. H. Ulig, Corrosion and Corrosion Control. Second Edition, John Wiley and Sons, Inc., New York, NY, 1971. 
13. A. B. Johnson, Jr., D. R. Pratt and G. E. Zima, A Survey of Materials and Corrosion Performance in Dry Cooling Applications. BNWL-1958, Battelle, Pacific Northwest Laboratories, Richland, WA 99352, March 1976.

14. D. W. Faletti and N. R. Gordon, Invention Report, February 26, 1976.

15. P. A. Ard and D. W. Faletti, Invention Report, March 6, 1976.

16. Fan Price List, Hudson Products, Houston, TX, November 1, 1974.

17. Motor Price Lists, Westinghouse Electric Co., Pittsburgh, PA, November 1975.

18. "Water Circulation System Component and Installation Costs for the Dry Cooling Program." C-62264, Vitro Engineering, Richland, WA, January 1976.

19. "Ammonia Circulating System Component Costs, Dry Cooling Program." C-62283, Vitro Engineering, Richland, WA, June 1976.

20. "Fiberglass Piping Costs, Dry Cooling Program." C-62283, Vitro Engineering, Richland, WA, September 1976.

21. "Prestressed Concrete Piping Costs, Dry Cooling Program." C-62283, Vitro Engineering, Richland, WA, September 1976.

22. Y. Onishi and D. S. Trent, Mathematical and Experimental Investigations on Dispersion and Recirculation of Plumes from Dry Cooling Towers at Wyodak Power Plant in Wyoming. BNWL-1982, Battelle, Pacific Northwest Laboratories, Richland, WA 99352, February 1976.

23. Surface Condenser Price List, Westinghouse Electric Corp., Pittsburgh, PA, December 31, 1973.

24. McKee-Berger-Manseuto, Inc., Building Cost File, 1976 Unit Prices, Western Edition. Construction Publishing Co., Inc., New York, NY.

25. 1976 Dodge Construction Systems Cost. Annual Edition No. 2, McGrawHil1 Information Sys tems Co., New York, NY.

26. D. R. Pratt, Scale Formation in Deluged Dry Cooling Systems. BNWL-2060, Battelle, Pacific Northwest Laboratories, Richland, WA 99352, May 1976.

27. E. Norde 11, Water Treatment for Industrial and Other Uses. Second edition, Reinhold Publishing Corp., New York, NY, 1961. 
28. F. R. Zaloudek, A Study of the Comparative Costs of Five Wet/Dry Cooling Tower Concepts. BNWL-2122, Battelle, Pacific Northwest Laboratories, Richland, WA 99352, to be published.

29. H. E. Pulver, Construction Estimates and Costs. Third edition, McGraw-Hi11 Book Company, Inc., New York, NY, 1960.

30. Schweyer, Process Engineering Economics. McGraw-Hill Book Company, Inc., New York, NY, 1955. 


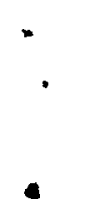


APPENDIX A

TUBING COST DATA 

APPENDIX A

TUBING COST DATA

The cost data compiled for both condenser tubing and plastic tubing are shown in Tables $A-1$ and $A-2$, respectively. These prices are f.o.b. the manufacturer's plant and were obtained from the following tubing suppliers:

\begin{tabular}{|c|c|c|}
\hline Type Tubing & $\begin{array}{c}\text { ASTM } \\
\text { Specification }\end{array}$ & Supplier \\
\hline $\begin{array}{ll}\text { Copper Alloys: } \\
\text { Admiral ty } & (443) \\
\text { Cu-10 Ni } & (706) \\
\text { Cu-30 Ni } & (715)\end{array}$ & $\begin{array}{l}B-111 \\
B-111 \\
B-111\end{array}$ & $\begin{array}{l}\text { Wolverine Tube } \\
\text { Bridgeport Brass }\end{array}$ \\
\hline $\begin{array}{l}\text { ATuminum Alloys: } \\
\text { 3003-0 } \\
3003-H 14 \\
6061-T 6\end{array}$ & $\begin{array}{l}B-210 \\
B-234 \\
B-234\end{array}$ & $\begin{array}{l}\text { ALCOA } \\
\text { Tube Sales, Seattle, WA }\end{array}$ \\
\hline $\begin{array}{l}\text { Carbon Steels: } \\
\text { Seamless } \\
\text { Welded }\end{array}$ & $\begin{array}{l}A-179 \\
A-214\end{array}$ & $\begin{array}{l}\text { Kilsby Tube, Seattle, WA } \\
\text { Babcock \& Wilcox } \\
\text { Pacific Tube }\end{array}$ \\
\hline $\begin{array}{l}\text { Stainless Steel: } \\
304 \text { Welded }\end{array}$ & $A-249$ & $\begin{array}{l}\text { Carpenter Steel } \\
\text { Pacific Tube }\end{array}$ \\
\hline $\begin{array}{l}\text { Tritium Alloys: } \\
\text { Grade } 1 \\
\text { Grade } 2\end{array}$ & $\begin{array}{l}B-338 \\
B-338\end{array}$ & $\begin{array}{l}\text { TIMET } \\
\text { Division of Titanium } \\
\text { Metals Corporation }\end{array}$ \\
\hline $\begin{array}{l}\text { Plastic Tubing: } \\
\text { Black HD Polyethylene } \\
\text { Black Polypropylene }\end{array}$ & & $\begin{array}{l}\text { Bunnel1 Plastics } \\
\text { Cadallac Plastics }\end{array}$ \\
\hline
\end{tabular}




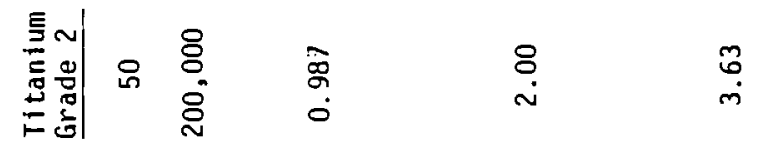

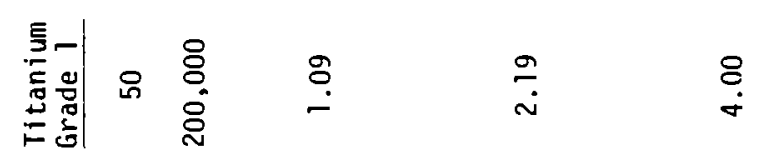

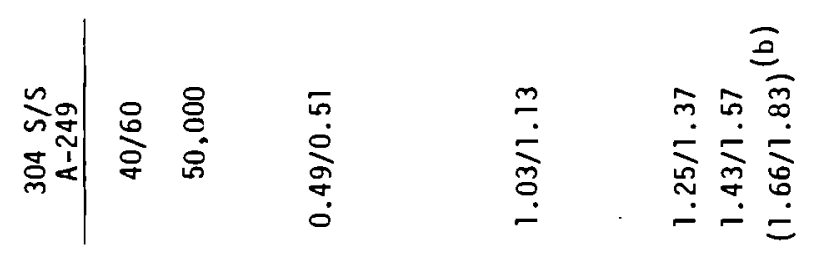

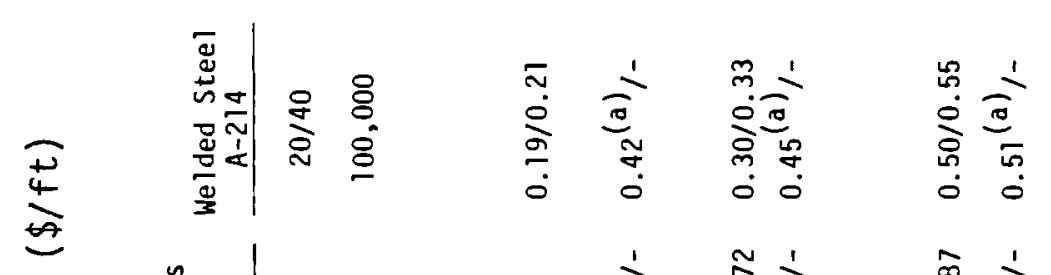

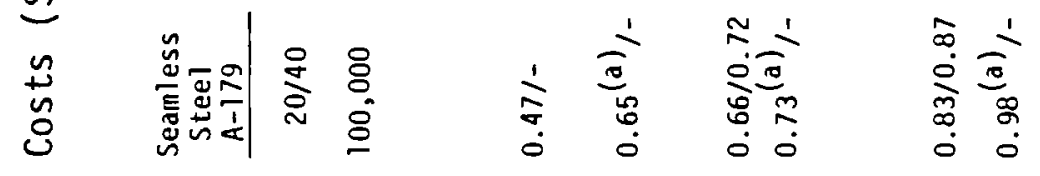

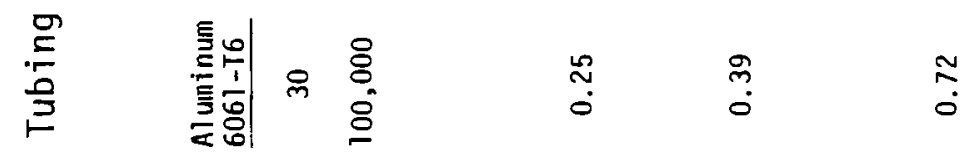

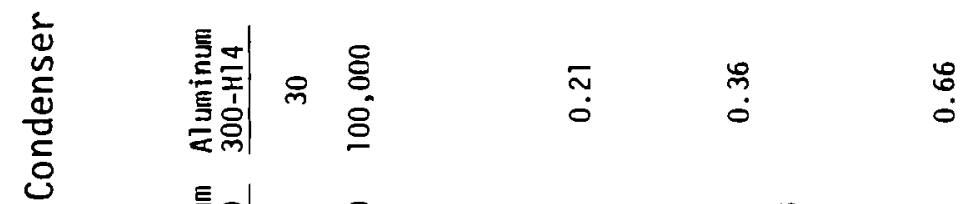

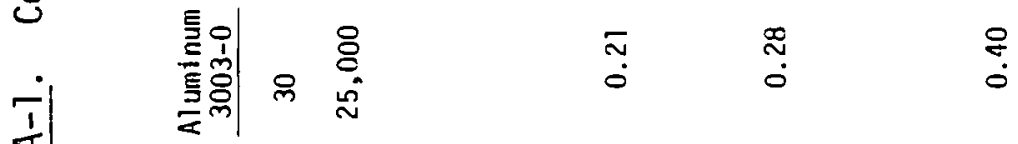

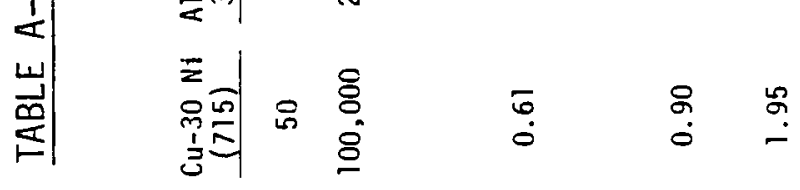

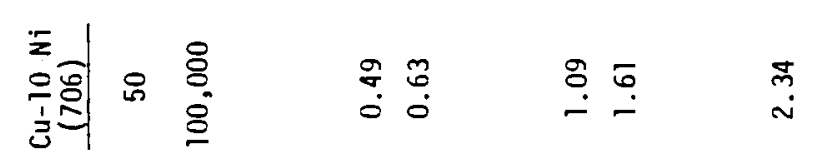

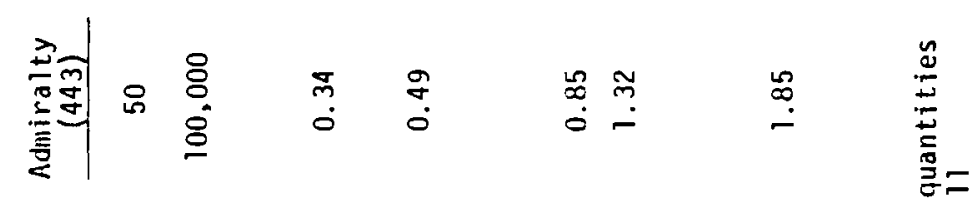

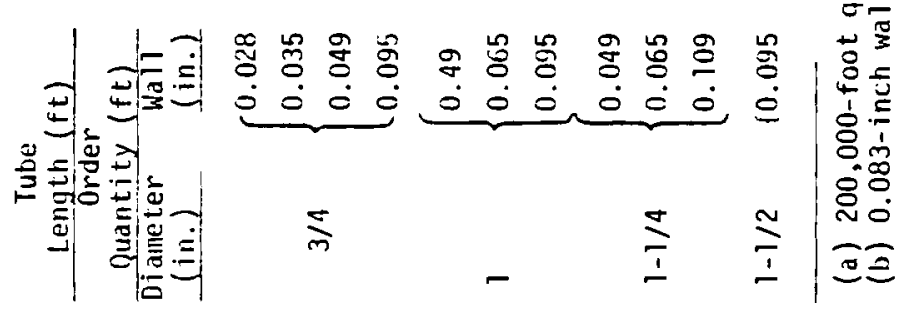


TABLE A-2. Plastic Tubing Prices $(\$ / 1000 \mathrm{ft})$

\begin{tabular}{|c|c|c|c|}
\hline $\begin{array}{c}\text { Diameter } \\
\text { (in.) } \\
\end{array}$ & $\begin{array}{l}\text { Wal11 } \\
\text { (in.) } \\
\end{array}$ & $\begin{array}{c}\frac{\left(400,000 / 4 \times 10^{8}\right.}{\text { Black High Density }} \\
\text { Polyethylene }\end{array}$ & $\begin{array}{c}\text { Quantities) } \\
\text { Black } \\
\text { Polypropylene }\end{array}$ \\
\hline $3 / 8$ & 0.040 & $15.93 / 12.50$ & $17.58 / 14.84$ \\
\hline $1 / 2$ & 0.050 & $29.71 /-$ & $26.50 /-$ \\
\hline $3 / 4$ & 0.062 & $-/ 40.39$ & $-/ 43.12$ \\
\hline
\end{tabular}



APPENDIX B

TUBING CORROSION DATA 
APPENDIX B

TUBING CORROSION DATA

\section{WATER QUALITY EFFECTS}

Corrosion allowances recommended for five commonly used tubing materials are shown in Table B-1 for normal steam condensate $\left(0.5 \mu \mathrm{mho} / \mathrm{cm}, \mathrm{O}_{2}<50 \mathrm{ppb}\right.$, pH 8.5 , velocity $2.7 \mathrm{in.} / \mathrm{sec}$ ), high-purity oxygen inhibited condensate $\left(0.1 \mu \mathrm{mho} / \mathrm{cm}, \mathrm{O}_{2} 150\right.$ to $200 \mathrm{ppb}, \mathrm{pH} 7.0$, velocity $\left.2.7 \mathrm{in.} / \mathrm{sec}\right)$, and inhibitor controlled condensate. The high-purity, oxygen-inhibited water quality is used in this country only in boiling water reactors. In Germany and Hungary, it is referred to as the "neutral method of operation" and is becoming a standard method of boiler water treatment. This quality of water is particularly desirable for systems containing both steel and aluminum components. The method corisists of operating the boiler feedwater and condensate at very low dissolved solids concentration $(\sim 0.1 \mu \mathrm{mho} / \mathrm{cm})$, neutral $\mathrm{pH}$, and dosing with hydrogen peroxide to an oxygen level of about 150 to $200 \mathrm{ppb}$. This amount of oxygen, in very pure water at temperatures below $250^{\circ} \mathrm{C}$, causes passive iron oxides to form on steel surfaces and thus prevents further corrosion (Reference 1, pp. 44-45 and 84-87).

Table B-2 presents liner wall thicknesses required for both wrap-on and extruded aluminum fin tubes when exposed to either normal or high-purity oxygen inhibited water. The tubing materials are carbon steel, 304 stainless steel, admiralty, Cu-10 Ni, and 6061 aluminum. The minimum wal1 thickness required for finning is indicated when a significant corrosion allowance is not required. 


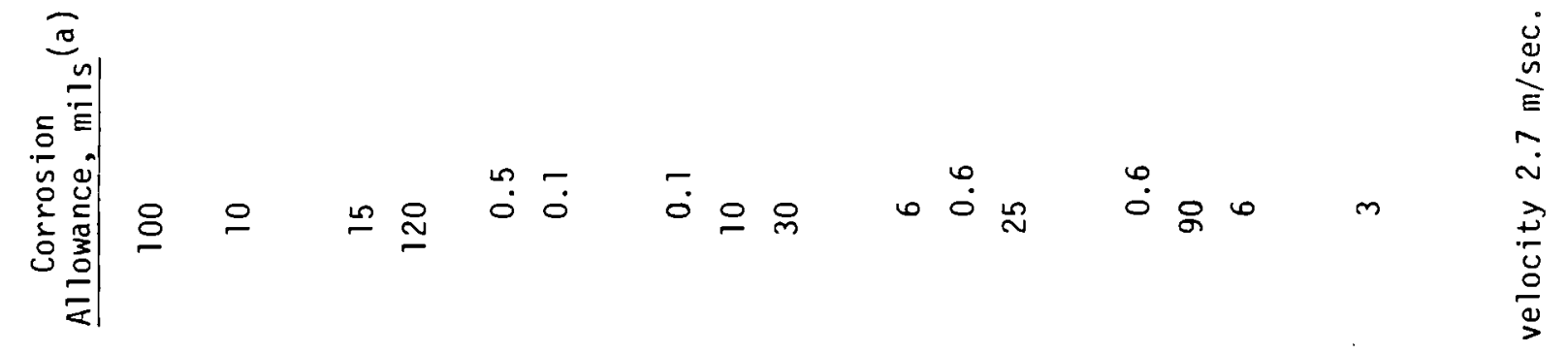

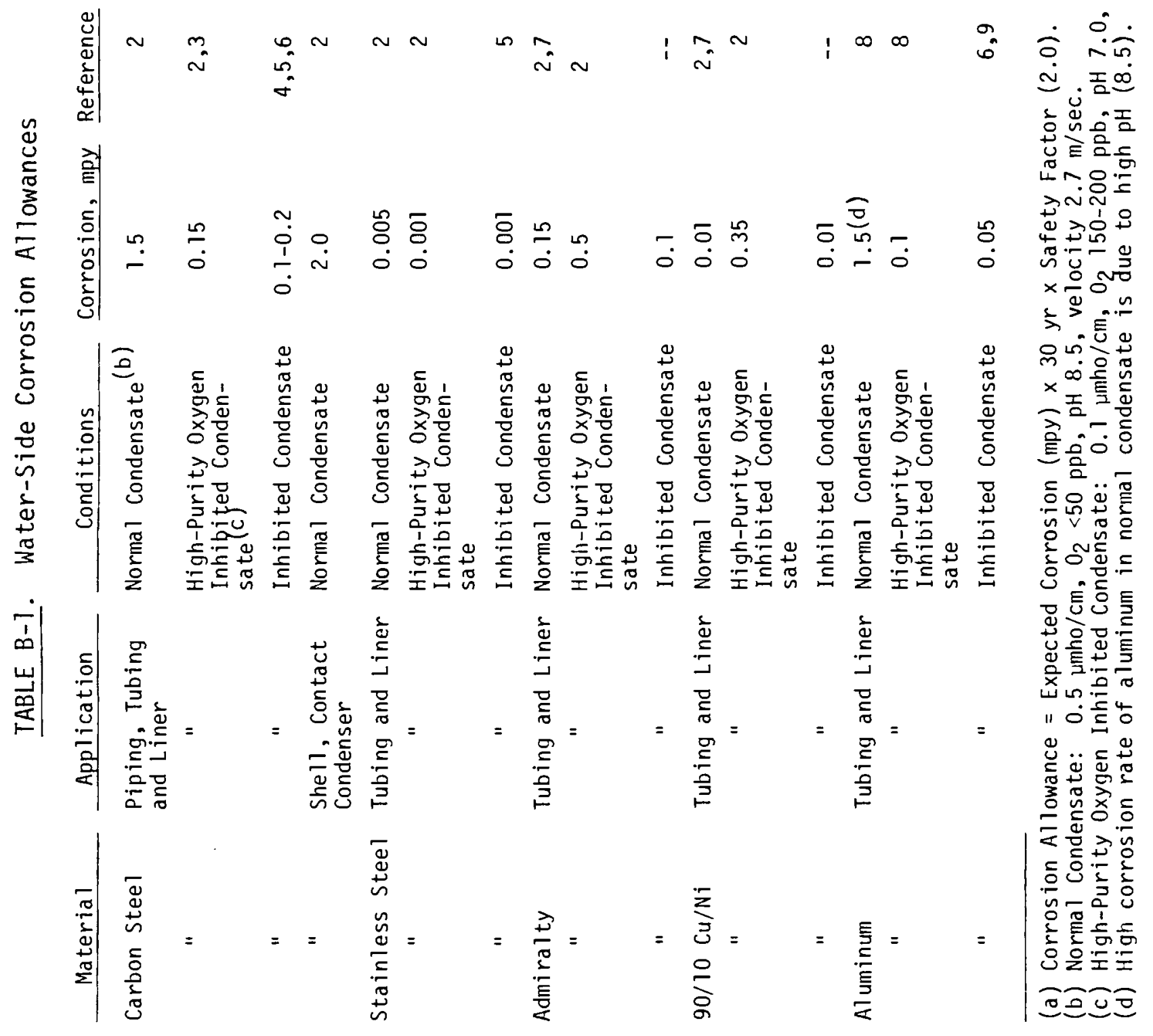




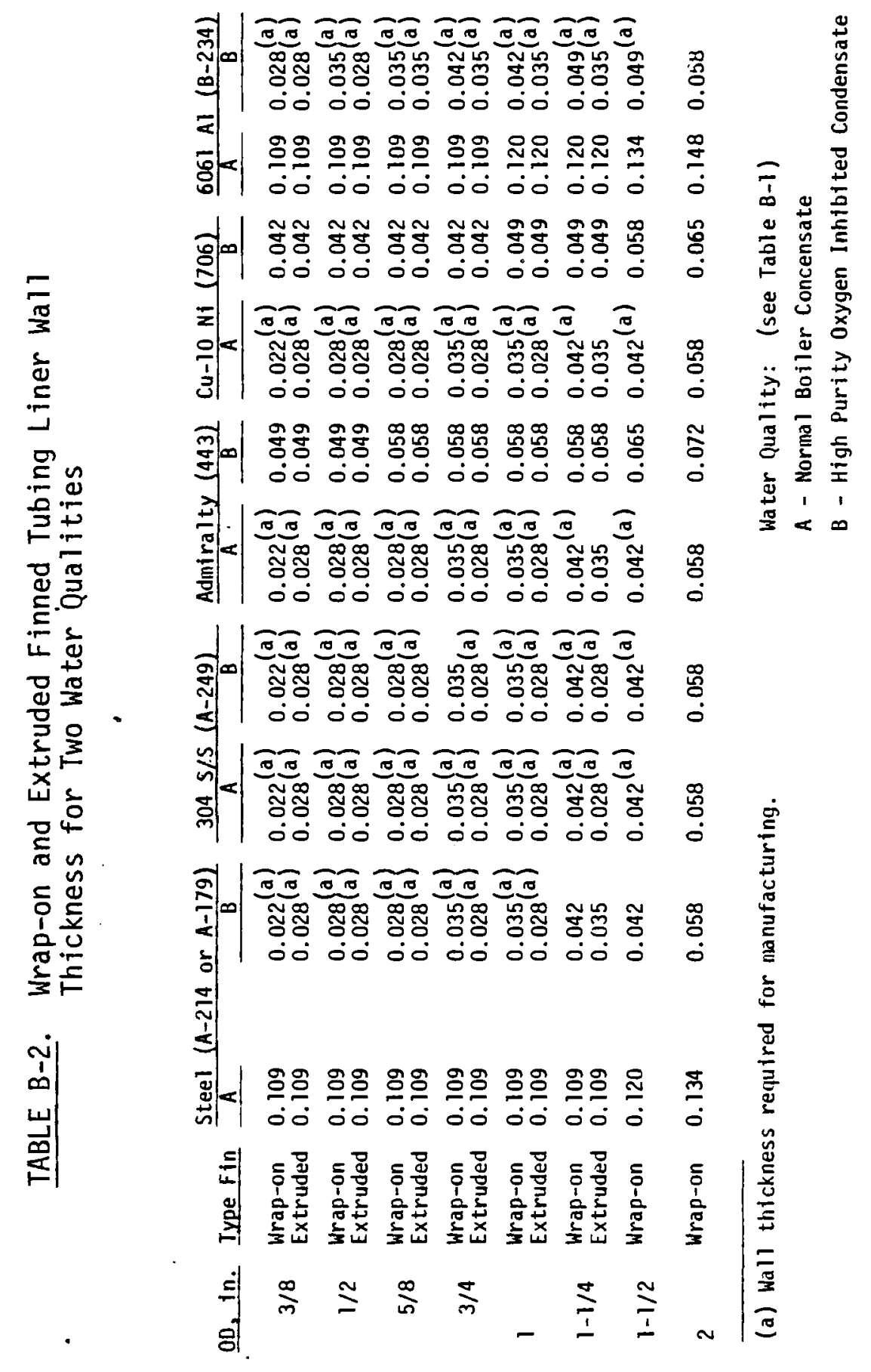




\section{FLUID VELOCITY EFFECTS}

Erosion-corrosion is encountered when particles impinge on a metal surface causing the removal of the protective surface films, such as oxide films or adherent corrosion products. A severe form of erosion-corrosion is termed impingement corrosion and occurs in turns or ells of pipes, surfaces of impellers, etc. Steam erosion is a form of impingement corrosion whereby high velocity wet steam impinges on metal surfaces producing a roughened surface.

Table B-3 shows, from the standpoint of erosion-corrosion, the maximum allowable velocities for water (three qualities), saturated steam, liquid ammonia and gaseous ammonia in tubing made of six different alloy types. Aluminum tubing cannot withstand direct high-velocity steam impingement ( $2100 \mathrm{fps}$ ) from the turbine. The maximum allowable velocity of steam in aluminum tubing is a function of steam quality. Further work is required with aluminum alloys to better define acceptable velocity limits.

The Piping Handbook gives reasonable velocities for carbon steel piping exposed to low pressure steam in the range of 67 to $100 \mathrm{fps}$, while a higher range of 200 to $250 \mathrm{fps}$ is given in Reference 10 for l.ow-pressure steam. Available data for steam in stainless steel piping are sparse, but generally indicate velocities can be higher than in carbon steel.

Reliable velocity data for ammonia are not readily available. Generally acceptable velocities are 7 fps for liquid ammonia in carbon steel piping and 100 to $150 \mathrm{fps}$ for gaseous ammonia. The following equation is a good rule of thumb for determining acceptable velocities.

$$
\begin{aligned}
\rho V^{2} & =\text { Constant } \\
\text { where } \rho & =\text { density in } 1 \mathrm{~b} / \mathrm{ft}^{3} \\
V & =\text { velocity in } \mathrm{ft} / \mathrm{sec} .
\end{aligned}
$$

Usual industrial practice assigns a value of 1000 to 2500 to the constant; 2500 is usually the economic limit. The value can go as high as 10,000 without serious erosion problems. Use of this formula gives maximum allowable velocities of $1100 \mathrm{fps}$ for saturated steam at $140^{\circ} \mathrm{F}, 110 \mathrm{fps}$ for saturated 
ammonia vapor at $110^{\circ} \mathrm{F}$, and 16.7 fps for liquid ammonia at $110^{\circ} \mathrm{F}$. Reliable sources indicate probable little difference, from an erosion standpoint, between the performance of carbon steel and aluminum in ammonia service. 


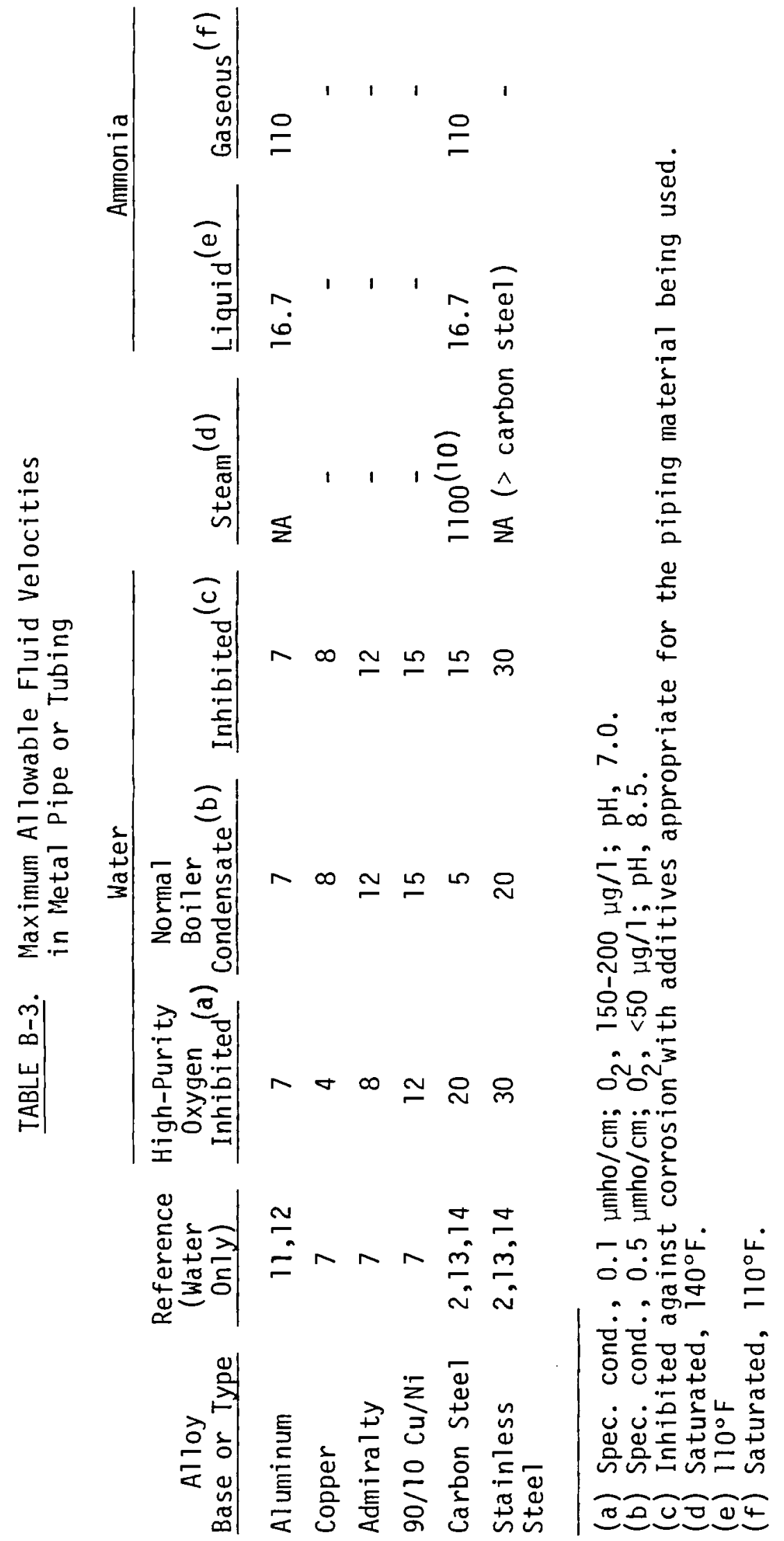


APPENDIX C

TUBE FINNING COSTS 
APPENDIX C

TUBE FINNING COSTS

Both technical and pricing information on tube finning was obtained from contacts with and/or quotes from the following firms:

Hudson Products Corporation

The Marley Company

McElroy Manufacturing, Inc.

Rome-Turney Radiator Company

Voss Fin Tube Products, Inc.

Wolverine, Division UOP, Inc.

\section{EXTRUDED FIN COST}

Figure $\mathrm{C}-1$ shows extruded fin costs plotted against fin material weight for 3003 aluminum fins. The line representing the cost curve is approximate, representing a best fit on cost points. These costs do not include end preparation or a liner.

\section{WRAP-ON FIN COSTS}

Wrap-on fin manufacturing costs are composed of the cost of the fin stock and the cost of applying the fin stock to the tube. According to a finned tube manufacturer, aluminum fin stock runs about $\$ 0.90 / 1 \mathrm{~b}$ while mild steel (1010 steel) stock can be obtained for $\$ 0.20$ to $\$ 0.24 / 1 \mathrm{~b}$, depending upon whether the stock is tinned.

The cost of applying the fin and spacer in a full production facility is analyzed below. This analysis assumes two shifts/day with one finning machine. Finning rates are a function of the fin pitch and liner diameter. A liner diameter of 1 inch and a fin pitch of 10/inch was assumed here. 


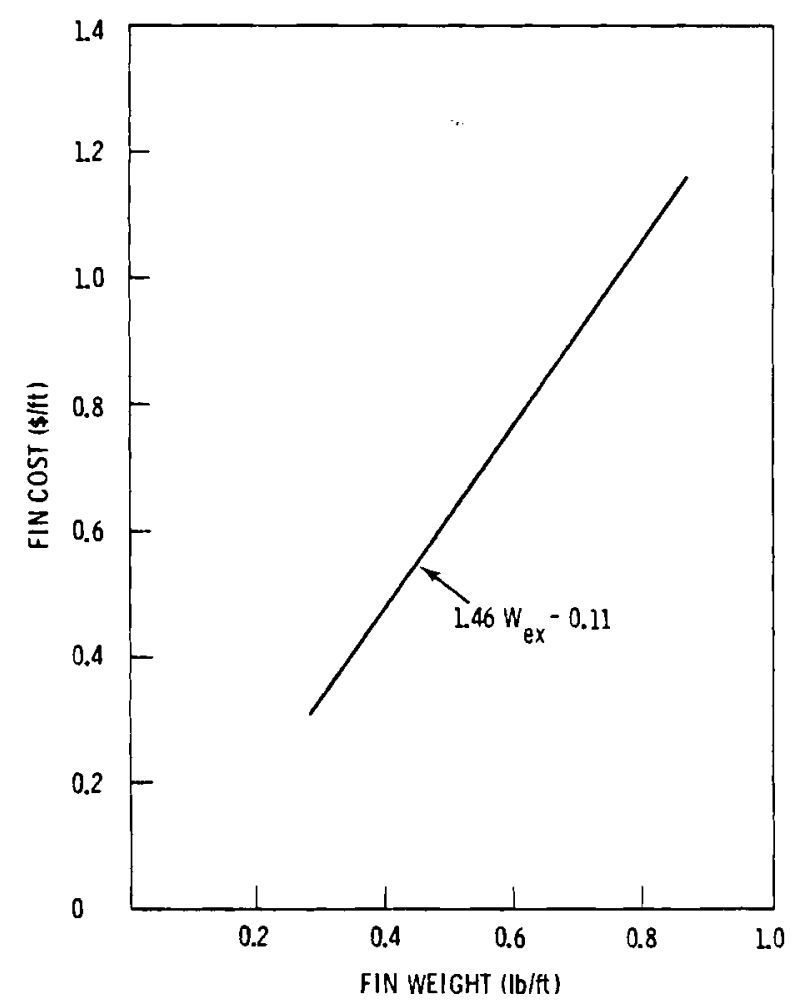

FIGURE C-1. Extruded 3003 Aluminum Fin Costs Versus Fin Weight (Excluding Tube End Preparation and Liner Costs)

Wrap-on Finning Cost Analysis

Equipment and Labor Requirements

(1 finning machine operated two shifts/day)

1 overhead crane

1 finning machine and tooling

spacer casting equipment

miscellaneous feed and run-out tables

Labor: (per shift)

2 operators

1 foreman

4 laborers

$1 / 2$ QA man (part-time)

$1 / 2$ janitor (part-time) 


\section{Capital Investment}

Equipment:

1 overhead crane ( $1 / 2$ ton)

$\$ 100,000$

1 finning machine and tooling

80,000

spacer casting equipment

20,000

miscellaneous feed and run-out

12,000 tables

$\$ 212,000$

Building - $(80 \times 160 \mathrm{ft})$ at $\$ 30 / \mathrm{ft} \quad 384,000$

Warehouse - $(60 \times 100 \mathrm{ft})$ at $\$ 30 / \mathrm{ft} \quad 180,000$

Maintenance shop and equipment

50,000

Cash and materials inventories

Total Assets

$\$ 614,000$

800,000

$\$ 1,626,000$

Operating Costs per Year (Assume two 8-hr shifts/day)

1 foreman $(1 \times \$ 8 / \mathrm{hr} \times 4160)$

$\$ 33,280$

1 operator $(1 \times \$ 6 / \mathrm{hr} \times 4160)$

24,960

4 laborers $(4 \times \$ 5.50 / \mathrm{hr} \times 4160)$

91,520

$1 / 2$ quality control man $(1 / 2 \times \$ 6.60 / \mathrm{hr}$ $\times 4160)$

13,728

$1 / 2$ janitor (part-time) $(1 / 2 \times \$ 4.08 / \mathrm{hr}$ $\times 4160)$

$$
\begin{aligned}
& \text { Total Wage } \\
& 8,320 \\
& \$ 163,488 \\
& \text { Benefits ( } 30 \% \text { of wage) } \\
& 49,046 \\
& \text { Overhead at } 67 \% \text { of labor } \\
& \text { (maintenance, utilities, } \\
& \text { etc.) } \\
& \text { Total Labor } \\
& \text { Depreciation (15-yr life) } \quad 55,000 \\
& \text { Inves tment Interest } \\
& \text { ( } 6 \% \text { of cash and material) } \quad 48,000 \\
& \$ 457,900 \\
& \text { Contingency at } 10 \% \\
& \text { Total } \\
& 45,790 \\
& \$ 503,700
\end{aligned}
$$


Production rate:

$$
2000 \mathrm{rpm}=15 \mathrm{ft} / \text { minute output }
$$$$
\text { assume } 75 \% \text { plant factor or }
$$$$
3120 \mathrm{hr} / \mathrm{yr} \text { actual production }
$$$$
\text { yearly production }=(60)(3120)(15)=2,808,000 \mathrm{ft} / \mathrm{yr}
$$$$
\text { assume } 90 \% \text { yield }=2,527,200 \mathrm{ft} / \mathrm{yr}
$$$$
\text { or } 503,700 / 2,527,000=\$ 0.20 / \mathrm{ft}
$$

Assume: $\$ 0.15 / \mathrm{ft}$ for finning

$\$ 0.05 / \mathrm{ft}$ for spacer application and end securing

Therefore, if spacers are spaced at 5-ft intervals, cost/spacer $\approx \$ 0.25$ 
APPENDIX D

MATERIAL AND NOZZLE COSTS 
APPENDIX D

MATERIAL AND NOZZLE COSTS

\section{MATERIAL COSTS}

Considered here are material costs for the following dry cooling tower components:

\begin{tabular}{|c|c|}
\hline Components & Material \\
\hline Finned tube spacers & Casting zinc \\
\hline Headers & $\begin{array}{l}\text { Steel plate } \\
\text { Aluminum plate }\end{array}$ \\
\hline Bundle frame & Steel channel \\
\hline Fan plenum and ring & Steel steel \\
\hline
\end{tabular}

Except for the zinc spacers, the basic material costs and the fabrication costs are combined for these components.

Basic material cost information was obtained from three sources:

- American Metal Market News

- Stack Steel and Supply Company

- Ryerson Metals and Processing

The cost of zinc for casting on the metal market runs about $\$ 0.40 / 1 b$. An assumed 225 percent markup to cover purchasing and shipping raises this price to $\$ 0.50 / 1 \mathrm{~b}$ for the fin tube manufacturer.

The basic cost of steel and aluminum plate from a distributor is about $\$ 0.21 / 1 \mathrm{~b}$ for $\mathrm{A} 285-\mathrm{C}$ steel and $\$ 0.92 / 1 \mathrm{~b}$ for 6061 or 5083 aluminum f.o.b. job site in large quantity orders. Added to the material cost is the estimated cost of handling, cutting to the desired sizes, and machining the edges for welding. The cost of applying a protective coating to the external surface is also included. The addition for the cost of labor, equipment, and shop overhead for steel is estimated at $\$ 0.32 / 1 \mathrm{~b}$, making the total $\$ 0.53 / 1 \mathrm{~b}$. If 
the box is galvanized, the cost increase is estimated at $\$ 0.36 / 1 \mathrm{~b}$ making the total $\$ 0.57 / 1$ b. Similar cost increases for aluminum (no protective coating needed) are estimated at $\$ 0.38 / 1 \mathrm{~b}$, making the total cost $\$ 1.30 / 1 \mathrm{~b}$.

Similar estimates were made for the fabrication and assembly of the bundle frame and fan plenum and rings. The total cost of the assembled bundle frame, including material, labor, equipment, and overheads, was estimated at $\$ 0.48 / 1 \mathrm{~b}$ if primed and painted or $\$ 0.53 / 1 \mathrm{~b}$ if galvanized. The cost of the assembled plenums with necessary reinforcing or stiffeners is estimated at $\$ 0.50 / 1 \mathrm{~b}$ if primed and painted, or $\$ 0.55 / 1 \mathrm{~b}$ if galvanized sheet is used.

\section{HEADER NOZZLE COSTS}

The header nozzle assembly consists of the flange and the flange-toheader transition adaptor. Costs were developed for nozzles using 150-1b rated flanges for the low pressure water systems and 300-1b rated flanges for the high pressure ammonia systems. The nozzle costs (\$ per inch of nozzle diameter) are approximately equal to the nozzle diameter for the low pressure nozzles and twice the nozzle diameter for the high pressure nozzles, based on flange costs in References 15 and 16 . The cost of making the header-to-nozzle weld is estimated at $\$ 3$ and $\$ 5$ per inch of nozzle diameter ( $\approx 12$ and $\$ 19$ per foot of circumference) for the low and high pressure nozzles, respectively. Thus the costs for the nozzles and attaching can be expressed as follows:

Low pressure nozzle cost

$$
C_{n}=\left(3+D_{n}\right) D_{n}
$$

High pressure nozzle cost

$$
\begin{aligned}
C_{n} & =\left(5+2 D_{n}\right) D_{n} \\
D_{n} & =\text { nozzle diameter }=2 \sqrt{\frac{F_{A}}{\pi}} \\
F_{A} & =\text { total bundle flow area per pass }\left(\text { in. }{ }^{2}\right) \\
& =\text { (liner tube flow area) } \times \text { (number of tubes per pass). }
\end{aligned}
$$




\section{APPENDIX E}

PLASTIC SPACER COSTS 
$+$ 


\section{APPENDIX E}

\section{PLASTIC SPACER COSTS}

The cost of tooling and manufacturing 30,000 foamed polycarbonate spacer panels was estimated by one manufacturer at $\$ 60 /$ panel, f.o.b. manufacturer's plant. The price is predicated on a panel $15 \mathrm{in}$. wide, $1 / 2$ in. thick and $12 \mathrm{ft}$ long with $35003 / 8$-inch diameter holes in an 0.8-inch equilateral triangle pattern. The polycarbonate material contains 10 percent by weight glass fibers (density $\approx 0.0314 \cdot \mathrm{lb} / \mathrm{in}^{3}{ }^{3}$ ). The weight/panel is $\approx 27.5 \mathrm{lb}$. Unit material costs are $\approx \$ 2.20 / 1 \mathrm{~b}$.

If nonfoamed polyvinyl chloride (PVC) were used instead of the foamed - polycarbonate, the cost per panel was estimated at $\$ 30$ each for the same quantities. The weight/panel would be $\approx 38.51 \mathrm{~b}$ (PVC density $\approx 0.044 \mathrm{lb} / \mathrm{in}^{3}{ }^{3}$ ); unit material cost would be $\approx \$ 1.57 / 1 \mathrm{~b}$. 
- 
APPENDIX $F$

HEADER WELDING COSTS 


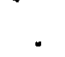

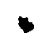




\section{APPENDIX $F$}

\section{HEADER WELDING COSTS}

Welding of header boxes can be accomplished with auto MIG welding using flux core filler wire. The unit cost of welding in a production welding shop can be approximated by assuming a rate of $\$ 26$ to $\$ 28$ per man-hour, which covers all shop costs including job overheads. (a) Welding supplies are not included. It is assumed that shop labor consists of:

- one foreman

- six welders

- six weider's heipers

- one inspector

With a visually-inspected weld, assume each welder and helper can average about $120 \mathrm{ft}$ of weld per 8-hour shift welding $1 / 2$-inch thick steel.

$$
\begin{aligned}
& \text { Weld output }=6(120)=720 \mathrm{ft} / \text { day } \\
& \begin{aligned}
\text { Costs } & =\$ 2912 \text { labor }+\$ 250 \text { Welding Supplies } \\
& =\$ 3162 / \text { day using } \$ 26 / \text { man-hour for a } 112-\mathrm{hr} \text { shift. }
\end{aligned} \\
& \text { Unit weld costs }=\frac{3386}{720}=\$ 4.39 / 1 \text { ineal foot }
\end{aligned}
$$

Use $\$ 4.50 / 1$ ineal foot

If a partial ( $<20$ percent) weld radiography is performed, the output would be cut about 50 percent, thus increasing weld costs to about $\$ 9 / 1$ ineal foot.

(a) Discussions with pipe fabricators 


\section{APPENDIX G}

PLASTIC TUBE BUNDLE ASSEMBLY COSTS 
• 
APPENDIX G

PLASTIC TUBE BUNDLE ASSEMBLY COSTS

Assembly of the plastic tube bundles, which require large numbers of small closely spaced tubes, would justify a mechanized process to speed up production and reduce labor costs. Assume the shop is equipped and staffed to assemble enough bundles for a 1000-MW plant ( $\approx 600$ bundles) in a year's time. The shop operates 2 shifts/day, 5 days/week, 52 weeks/year $(4160$ hours/year total running time) and output is three assembled bundles per day.

\section{OUTLINE OF ASSEMBLY OPERATION}

An outline of a proposed process with equipment and manpower requirements follows.

I. Lay out tubing and assemble with spacers and tube sheet
A. Equipment

1. overhead crane

2. 40 ( $8 \mathrm{ft}$ diameter) plastic reels

3. mobile platform

4. miscellaneous fixtures

B. Labor

1. one crane operator

2. three laborers

II. Attach side channels and cross bracing

A. Equipment

1. overhead crane

2. miscellaneous fixtures

B. Labor

1. one crane operator

2. six laborers 
III. Seal tubing to tube sheets

A. Equipment

1. compound extruder

2. fixtures and dams

B. Labor

1. one crane operator

2. one helper

IV. Assemble header bonnet and pressure test

A. Equipment

1. pressurizing equipment

2. hoist equipment

B. Labor

1. one operator

2. two helpers.

COST ANALYSIS

Following is a listing of the estimated capital investment and the operating costs. The operating costs include only shop overheads.

I. Capital Investment

Equipment (installed)

2 overhead cranes

$\$ 250,000$

mobile platform

200,000

40 plastic reels

80,000

1 elastomer extruder

100,000

fixtures and miscellaneous equipment

150,000

bundle transporter

40,000

$\$ 820,000$

Buildings

shop $(80 \mathrm{ft} \times 250)$ at $\$ 30 / \mathrm{ft}$

$\$ 600,000$

warehouse $(80 \mathrm{ft} \times 250)$ at $\$ 30 / \mathrm{ft}$

600,000

$\$ 1,200,000$ 
Maintenance shop and equipment

Cash and material inventories

Total Assets

II. Operating Costs

1 foreman $(1 \times \$ 8 / \mathrm{hr} \times 4160)$

2 crane operators $(2 \times \$ 6 / \mathrm{hr} \times 4160)$

14 operators and laborers

$(14 \times \$ 5.50 / \mathrm{hr} \times 4160)$

1 quality control man

$(1 \times \$ 6.60 / \mathrm{hr} \times 4160)$

2 warehousemen $(2 \times \$ 5.50 \times 4160)$

Total wage

Benefits ( $30 \%$ of wage)

Shop overhead at $67 \%$ of 1 abor (maintenance, utilities, etc.)

Total labor

Depreciation (15 yr life)

Investment interest ( $6 \%$ of cash)

Subtotal

Contingency at $15 \%$

Total
150,000

$3,000,000$

$\$ 5,170,000$
$\$ 33,280$

49,920

320,320

27,456

45,760

$\$ 476,736$

143,020

415,237

$\$ 1,034,993$

144,700

180,000

$\$ 1,360,000$

204,000

$\$ 1,564,000$

Maximum production rate of 3 per day

(3) (5) $(52)=770 / y r$

Assume plant factor of $75 \%$ yields

585 actual output/year

Therefore, cost $/$ bundle $=\frac{1,564,000}{585}=\$ 2673 /$ bundle

Use $\$ 2700 /$ bundle . 
APPENDIX H

LOUVER AND SHUTTER COSTS 
APPENDIX H

LOUVER AND SHUTTER COSTS

Cost information on bundle louvers and hail screens was obtained from three manufacturers:

- Dun 1op Company

- Ruskin Manufacturing Company

- The Marley Company.

\section{LOUVERS}

Typical prices for louvers f.o.b. the manufacturer's plant, as well as installation costs, are indicated in Table $\mathrm{H}-\mathrm{I}$.

Louver field installation costs are estimated at $\$ 2.00 / \mathrm{ft}^{2}$, independent of quantity. Controls, piping and their installation would be on the order of 10 to 20 percent of the installed cost of the system.

TABLE H-1. Louver Costs $\left(\$ / \mathrm{ft}^{2}\right)$

Carbon steel, primed (a)

\begin{tabular}{ccc}
\multicolumn{3}{c}{ Total Surface Area $\left(\mathrm{ft}^{2}\right)$} \\
\hline$\frac{20,000}{4.65}$ & $\frac{80,000(\mathrm{~b})}{4.20}$ & $\frac{160,000 \text { or more(b) }}{3.75}$ \\
5.25 & 4.75 & 4.20 \\
6.15 & 5.55 & 4.90 \\
5.80 & 5.25 & 4.65
\end{tabular}

(a) Iron oxide primer

(b) If all sections are essentially the same design 
The cost of pneumatic actuators adds $\$ 0.83$ per square foot, independent of quantity. Therefore, the cost of carbon steel mill galvanized louvers for a $160,000-\mathrm{ft}^{2}$ facility would be:

\begin{tabular}{lc} 
Louvers & $\$ 4.20$ \\
Actuators & 0.83 \\
Installation & 2.00 \\
$\quad$ Subtotal & $\$ 7.03$ \\
Controls (15\%) & 1.05 \\
\multicolumn{1}{c}{ Total } & $\overline{\$ 8.08 / \mathrm{ft}^{2}}$
\end{tabular}

HAIL SCREENS

Table H-2 shows the typical hail screen prices, f.o.b. the manufacturer's plant.

Hail screen field installation is estimated at $\$ .50 / \mathrm{ft}^{2}$, independent of quantity (bolted installation). The cost then becomes $\$ 1.82 / \mathrm{ft}^{2}$ for $160,000 \mathrm{ft}^{2}$ quantities of 13 gage screens.

TABLE H-2. Hail Screen Costs $\left(\$ / \mathrm{ft}^{2}\right)^{(a)}$

$\frac{\text { Total Surface Area }\left(\mathrm{ft}^{2}\right)}{\underline{20,000} \underline{80,000}}$

$3 / 4$ in. $x 13$ gage expanded metal, galvanized flattened $\$ 2.40 \quad \$ 1.68 \quad \$ 1.32$ $3 / 4$ in. $\times 9$ gage expanded metal, galvanized, nonflattened (heavy duty)

$\$ 4.80$

$\$ 3.36$

$\$ 3.12$

(a) Comes with 1 in. $x 1$ in. $\times 1 / 8$ in. galvanized angles on sections to fit purchaser's bundles. 
APPENDIX I

CIRCULATION SYSTEM COSTS 


\section{APPENDIX I}

\section{CIRCULATION SYSTEM COSTS}

Costs were determined for both water and ammonia circulation systems.

\section{WATER CIRCULATION SYSTEMS}

Installed costs for water circulation system components were obtained from Vitro Engineering. (15) The basic components were ASTM A-53 Grade A type carbon steel with a design pressure of $125 \mathrm{psig}$. Using this information, cost algorithms were developed to allow costing similar components for systems with pressures ranging up to about 150 psig. The 125-psig Vitro costs are for 20-ft pipe lengths with all field welding. The algorithm allows considering costs for systems with different grades of steel and includes shop welding for the small diameter piping.

The installed piping and fitting cost algorithms are as follows:

Installed Piping Costs $\left(I P_{c}\right)=$ (Unit material and shipping costs

+ welding costs + other installation costs $)(1+$ profit $)$

$$
I C_{x}=\left(A_{x} t_{w} C_{x}+B n D C_{w}+0_{x}\right)(1.1)
$$

$I C_{X}=$ Installed component price

$\$ / f t$ for pipe

$\$$ /each for other components

$t_{w}=$ pipe wal1 thickness (in.)

$$
\begin{aligned}
& t_{w}=\left(\frac{P D}{2 S+2 P y}+0.100\right) 7 / 8 \\
& P=\text { system design pressure (psi) } \\
& D=\text { pipe outside diameter (in.) } \\
& y=\text { material coefficient }=0.4 \\
& 0.100=\text { corrosion allowance } \\
& 7 / 8=\text { manufacturer's tolerance allowance }
\end{aligned}
$$




$$
\begin{aligned}
S & =a 110 w a b l e \text { stress (psi) } \\
& =12,000-\text { ASTM A-53, Gr B } \\
& =12,000-\text { ASTM A-139, Gr B } \\
& =12,400-\text { ASTM A-155, Gr C55 } \\
& =15,700-\text { ASTM A-155, Gr KC70 }
\end{aligned}
$$

(Increase $t_{w}$ to standard wall thickness if not on standard thickness)

$$
\begin{aligned}
& A=\text { Unit cost factor } \\
& \text { Pipe: } 1 \text { for ASTM A-53 or A139 Gr B Mat'1 } \\
& 1.05 \text { for ASTM } 155 \text { Gr C55 Mat' } 1 \\
& 1.1 \text { for ASTM } 155 \text { Gr KC70 Mat'1 }
\end{aligned}
$$

Fittings: 1 for A285 Gr B Mat'l

1.05 for A515 Gr 70 Mat'1

$C_{x}=$ Basic material and shipping factor (See Table I-1)

$B=$ Weld cost factor for shop welding

$=1$ for all field welds (20 ft pipe lengths)

$=0.75$ for 1 shop and 1 field weld (40 ft pipe lengths)

$=0.67$ for 2 shop and 1 field welds (60 ft pipe lengths)

$\mathrm{n}=$ Component factor

$=0.084$ for pipe

$=3.34$ for all fittings except tees and reducers

$=5.01$ for tee

$=1.67\left(D+\frac{D}{d}\right)$ for reducers $d=$ small reducer diameter (in.)

$C_{w}=$ Unit weld costs (\$)

$=20.17 t_{w}-2.33$ for $t_{w}=0.562$ in.

$=34.79 t_{w}-10.42$ for $t_{w}>0.562$ to $1.0 \mathrm{in}$.

$0_{x}=$ other installation costs $(\$)$

See Table I-1 for factor for both above- and below-ground installation.

Pump costs for circulating water systems are shown in Table I-2. 


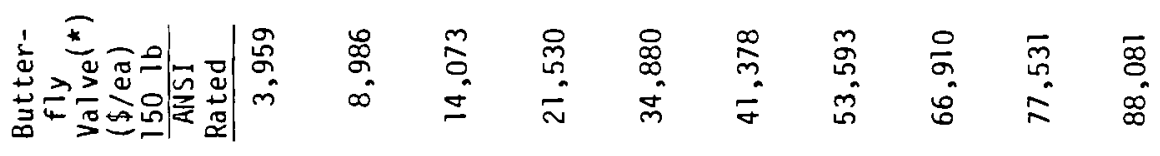

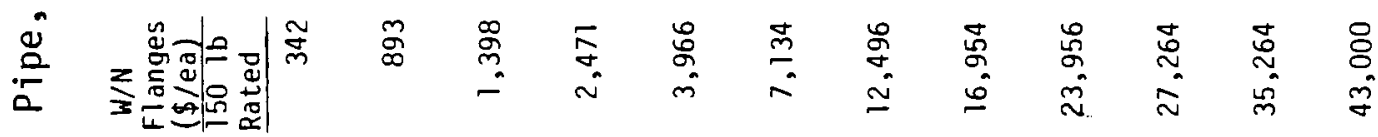

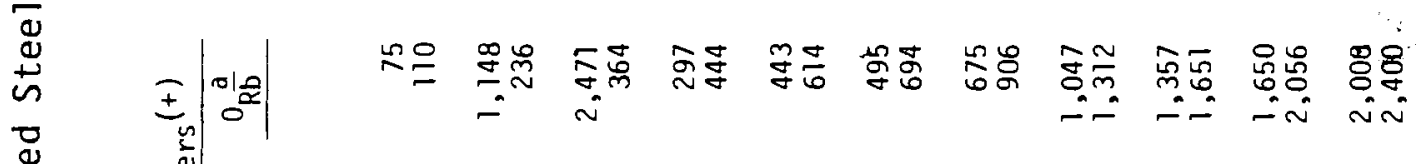

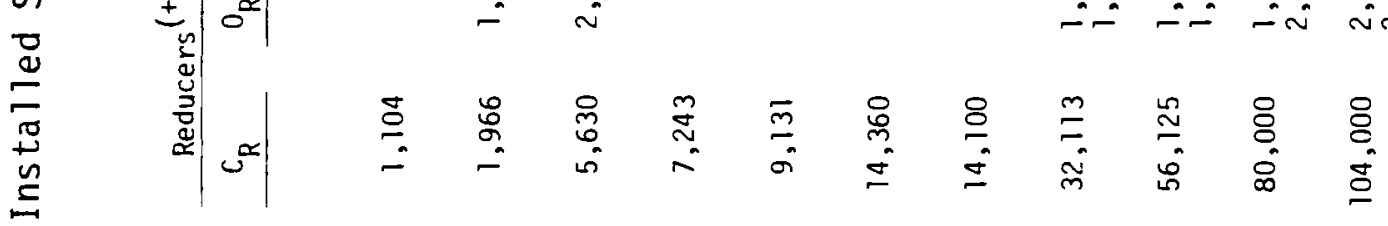

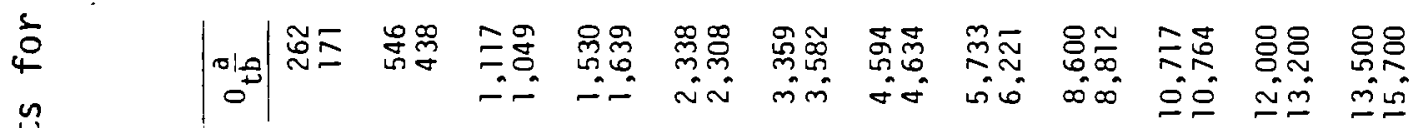

点

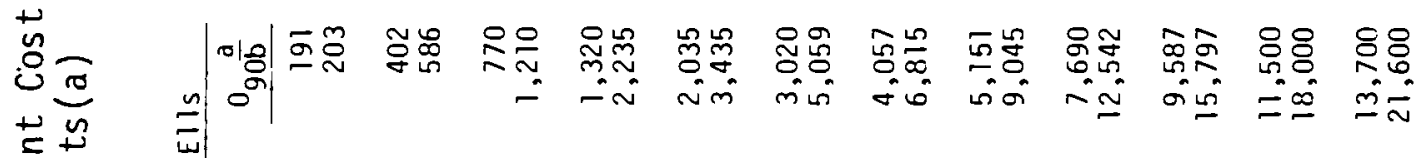

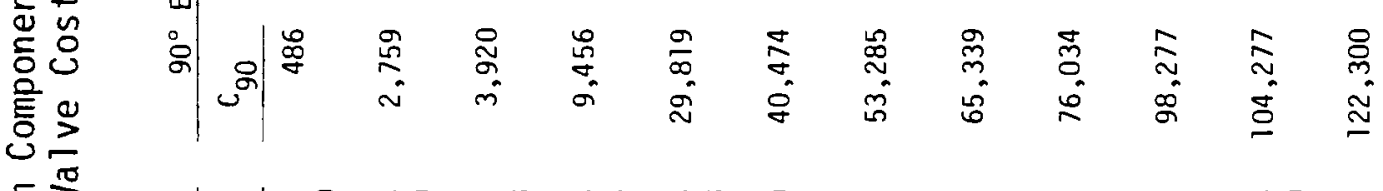

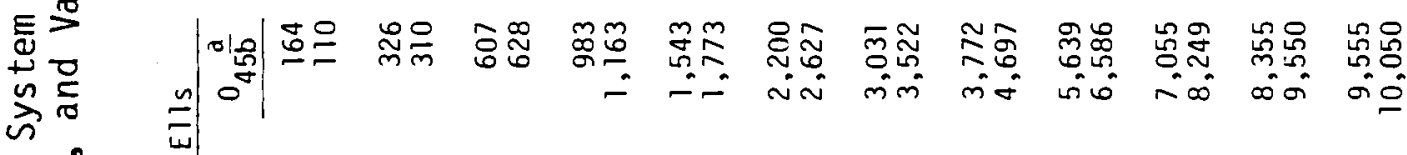

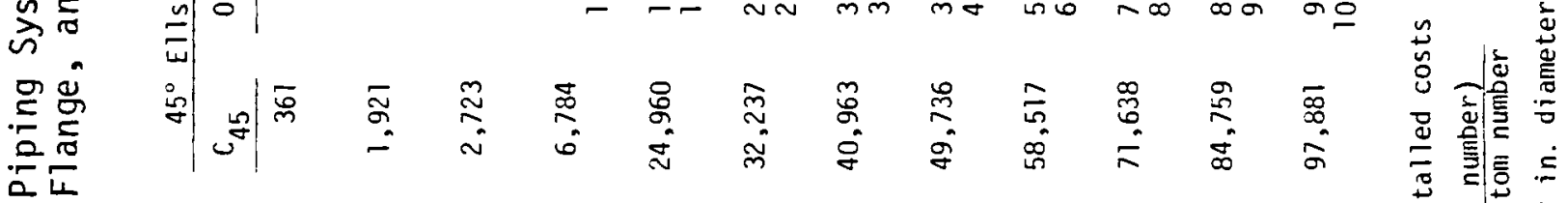

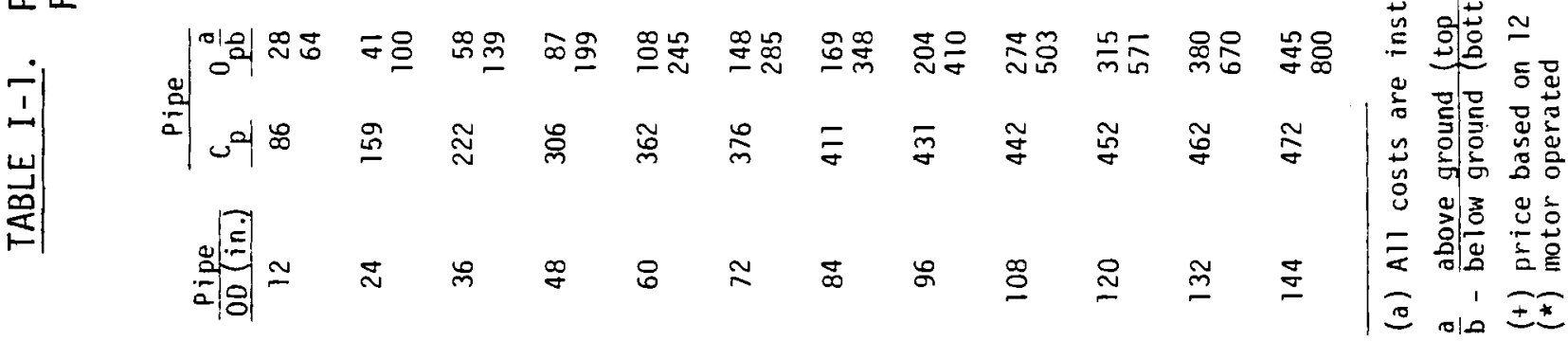


TABLE I-2. Pump and Motor Costs for 120-ft TDH Pumps

$\begin{array}{cc}\begin{array}{cc}\text { Pump Size } \\ \text { (GPM) }\end{array} & \begin{array}{c}\text { Motor Size } \\ \text { (HP) }\end{array} \\ 10,000 & 400 \\ 25,000 & 900 \\ 50,000 & 1800 \\ 100,000 & 3600 \\ 150,000 & 5400\end{array}$
Installed Pump and Motor Costs (\$) 35,100 65,300 130,800 261,400 392,300

\section{AMMONIA CIRCULATION SYSTEM}

Installed costs for ammonia circulation system components were developed by Vitro Engineering for a design pressure of 350 psig. (16) The piping components are carbon steel conforming to ASTM A53 Grade B materials for seamless pipe sizes up through $24 \mathrm{in}$. and ASTM Al39 Grade B for larger diameter welded pipes. Costs for a 450-psig ammonia system were determined by extrapolating the 350-psig system costs as required for the 450-psig system. The 450-psig system costs are given in Table I-3.

Ammonia pump, liquid separator, and storage tank costs are given in Table I-4 for the 450-psig system. 
TABLE I-3. Installed Component Costs for A 450-psig Ammonia Circulation System

\begin{tabular}{|c|c|c|c|c|c|c|c|}
\hline $\begin{array}{l}\text { Pipe } \\
O D(\text { in.) }\end{array}$ & $\begin{array}{r}\text { Pipe } \\
(\$ / L . F .) \frac{a}{b} \\
\end{array}$ & $\begin{array}{r}45^{\circ} \mathrm{E} l 1 \mathrm{~s} \\
(\$ . / \mathrm{ea}) \frac{\mathrm{a}}{\mathrm{b}} \\
\end{array}$ & $\begin{array}{r}90^{\circ} \mathrm{E} 11 \mathrm{~s} \\
(\$ / \mathrm{ea}) \frac{\mathrm{a}}{\mathrm{b}} \\
\end{array}$ & $\begin{array}{c}\text { Tees } \\
(\$ / \text { ea }) \frac{a}{b}\end{array}$ & $\begin{array}{r}\text { Reducer } \\
(\$ / \text { ea }) \frac{\mathrm{a}}{\mathrm{b}}\end{array}$ & $\begin{array}{c}W / N \\
\text { Flanges } \\
(\$ / \text { ea }) \\
3001 \mathrm{~b} \\
\text { Rated } \\
\end{array}$ & $\begin{array}{l}\text { Gate } \\
\text { Valves }(*) \\
\text { (\$/ea) } \\
350 \text { Ib } \\
\text { Rated } \\
\end{array}$ \\
\hline 3 & $\begin{array}{l}20 \\
39\end{array}$ & $\begin{array}{l}177 \\
122\end{array}$ & $\begin{array}{l}179 \\
146\end{array}$ & $\begin{array}{l}261 \\
157\end{array}$ & & 57 & 1,885 \\
\hline 6 & $\begin{array}{l}34 \\
60\end{array}$ & $\begin{array}{l}282 \\
230\end{array}$ & $\begin{array}{l}293 \\
275\end{array}$ & $\begin{array}{l}423 \\
344\end{array}$ & ${ }_{80}^{75}(3)^{(+)}$ & 136 & 2,873 \\
\hline 12 & $\begin{array}{r}73 \\
113\end{array}$ & $\begin{array}{l}619 \\
558\end{array}$ & $\begin{array}{l}703 \\
715\end{array}$ & $\begin{array}{r}1,036 \\
935\end{array}$ & $\begin{array}{l}312(6) \\
320\end{array}$ & 520 & 7,093 \\
\hline 18 & $\begin{array}{r}96 \\
147\end{array}$ & $\begin{array}{r}1,038 \\
947\end{array}$ & $\begin{array}{l}1,329 \\
1,354\end{array}$ & $\begin{array}{l}2,103 \\
1,965\end{array}$ & $\begin{array}{l}763(12) \\
787\end{array}$ & 1,031 & 16,742 \\
\hline 24 & $\begin{array}{l}155 \\
219\end{array}$ & $\begin{array}{l}2,175 \\
2,157\end{array}$ & $\begin{array}{l}2,730 \\
2,937\end{array}$ & $\begin{array}{l}3,942 \\
3,825\end{array}$ & $\begin{array}{l}1,729 \\
1,775\end{array}(18)$ & 1,918 & 26,742 \\
\hline 36 & $\begin{array}{l}510 \\
599\end{array}$ & $\begin{array}{l}13,161 \\
13,184\end{array}$ & $\begin{array}{l}15,656 \\
16,190\end{array}$ & $\begin{array}{l}25,844 \\
25,775\end{array}$ & $\begin{array}{l}9,313 \\
9,390\end{array}(24)$ & 4,422 & 77,756 \\
\hline 48 & $\begin{array}{l}719 \\
841\end{array}$ & $\begin{array}{l}27,022 \\
27,220\end{array}$ & $\begin{array}{l}37,758 \\
38,765\end{array}$ & $\begin{array}{l}37,484 \\
37,604\end{array}$ & $\begin{array}{l}16,839 \\
16,965\end{array}$ & 9,222 & 141,368 \\
\hline 60 & $\begin{array}{l}1,159 \\
1,316\end{array}$ & $\begin{array}{l}47,876 \\
48,129\end{array}$ & $\begin{array}{l}63,583 \\
65,123\end{array}$ & $\begin{array}{l}69,150 \\
69,116\end{array}$ & $\begin{array}{l}36,352 \\
36,527\end{array}$ & 14,704 & 186,792 \\
\hline 84 & $\begin{array}{l}2,161 \\
2,359\end{array}$ & $\begin{array}{l}119,886 \\
120,426\end{array}$ & $\begin{array}{l}152,073 \\
155,107\end{array}$ & $\begin{array}{l}144,599 \\
144,642\end{array}$ & $\begin{array}{r}99,704 \\
100,077 \quad(608)\end{array}$ & 40,400 & 292,765 \\
\hline
\end{tabular}

a - above ground cost (top number)

$\bar{b}$ - below ground cost (bottom number)

(+) small diameter size (in.) shown in parentheses

(*) motor operated 
TABLE I-4. Installed Pump, Liquid Separator, and Storage Tanks for a 450-psig Ammonia System

\begin{tabular}{|c|c|c|}
\hline \multicolumn{3}{|c|}{ Pump (50 ft head) } \\
\hline Size $(\mathrm{gpm})$ & Motor (hp) & $\operatorname{cost}(\$)$ \\
\hline 10,000 & 125 & 44,700 \\
\hline 25,000 & 250 & 111,500 \\
\hline 50,000 & 500 & 156,800 \\
\hline
\end{tabular}

\begin{tabular}{cr}
$\begin{array}{c}\text { Flowrate } \\
\$ / \text { min }\end{array}$ & Cost $(\$)$ \\
\hline 46,000 & 199,700 \\
91,000 & 467,000 \\
182,000 & $1,228,370$
\end{tabular}

Storage Tanks

\begin{tabular}{cr}
\hline Size (Gal) & Cost (\$) \\
\hline 42,000 & 248,100 \\
50,000 & 287,900
\end{tabular}


APPENDIX J

ELECTRICAL SYSTEM COSTS 
APPENDIX J

ELECTRICAL SYSTEM COSTS

\section{MATERIAL AND LABOR COSTS}

Table J-1 presents material and labor costs for seven system concepts used to develop the electrical system cost algorithms. These are costs to the performing contractor and do not include his overheads or profits. The costing is divided into plant-associated equipment costs and motor-associated equipment costs. The plant-associated equipment costs include material and installation of the primary transformers, main switchgear, interconnecting cable and duct, and a switchgear building. The motor-associated equipment costs include material and installation of the cable and duct to the secondary transformers, the secondary transformers, motor switchgear, cable and duct to the motors, and the control circuits. Two buildings are also included to house the motor switchgear. Basic electrical diagrams of concepts 3,4 and 7 are shown in Figures J-1, J-2, and J-3 respectively. Motor feed systems of 480,2300 , and 6900 volts are represented in these three concepts. 
TABLE J-1. Estimated Equipment and Labor Costs (\$1000)

Seven Electrical Systems Concepts

Concept No.

Voltage: Distribution/Motor

Motor Size (HP)

Number of Motors

System Size (1000 HP)

$\begin{array}{ccc}1 & 2 & 3 \\ 13.8 \mathrm{kV} / 460 & 13.8 \mathrm{kV} / 460 & 13.8 \mathrm{kV} / 460 \\ 50 & 100 & 200 \\ 112 & 56 & 56 \\ 5.6 & 5.6 & 11.2\end{array}$

4
$13.8 \mathrm{kV} / 2300$
400
32
12.8

5
$13.8 / 2300$
600
32
19.2

$\begin{array}{cc}6 & 7 \\ 13.8 / 4160 & 6.9 \mathrm{kV} / 6.9 \mathrm{kV} \\ 1000 & 2000 \\ 24 & 12 \\ 24 & 24\end{array}$

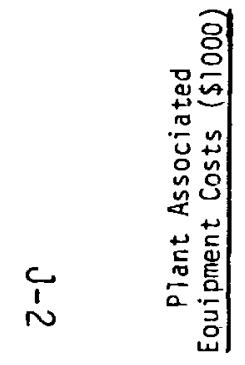

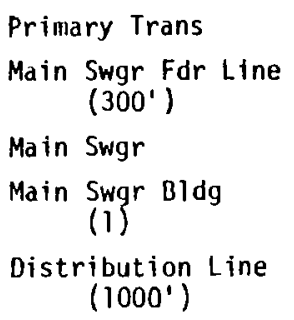

Secondary Transfer Hotor $\operatorname{Swgr}_{\left(100^{\prime}\right)}$ For Line

Motor Swgr

Motor Fdr Line

$$
\text { (250') }
$$

Motor Swgr Bldgs

$$
\text { (2) }
$$

Motor Control Lines (1200')

Total

Mat' 1 and Labor Costs

TOTAL SYSTEM COSTS

$\begin{array}{ccccccccccccccc}\text { Mat'l } & \text { Labor } & \text { Mat'l } & \text { Labor } & \text { Mat'l } & \text { Labor } & \text { Mat'l } & \text { Labor } & \text { Mat'l } & \text { Labor } & \text { Mat'1 } & \text { Labor } & \text { Mat' 1 } & \text { Labor } \\ 440 & 24 & 440 & 24 & 500 & 28 & 500 & 28 & 540 & 30 & 580 & 30 & 580 & 30 \\ 18 & 9.6 & 18 & 9.6 & 22.2 & 11.4 & 22.2 & 11.4 & 28.2 & 13.8 & 36.6 & 16.8 & 66.6 & 31.8 \\ 54 & 17 & 54 & 17 & 70 & 17 & 60 & 16 & 60 & 16 & 70 & 16 & 70 & 16 \\ 45 & - & 45 & - & 45 & - & 45 & - & 45 & - & 45 & - & 45 & - \\ 29 & 11 & 29 & 11 & 45 & 22 & 44 & 23 & 60 & 32 & 75 & 40 & 101 & 76\end{array}$

$\begin{array}{rccccccccccccc}43.8 & 9 & 43.8 & 9 & 87.6 & 18 & 72.4 & 14.6 & 94 & 18 & 117.5 & 22.5 & - & - \\ 47.5 & 22.2 & 47.5 & 22.2 & 95 & 44.5 & 29.9 & 12.5 & 45 & 18.6 & 56.5 & 23.5 & - & - \\ 140 & 20 & 115 & 15 & 272 & 20 & 124 & 16 & 126 & 17 & 98 & 17 & 80 & 11.4 \\ 56 & 53.2 & 96.6 & 49.0 & 156.8 & 81.2 & 51.2 & 32.8 & 76 & 40 & 63 & 33 & 32.1 & 15.9 \\ 90 & - & 90 & - & 90 & - & 90 & - & 90 & - & 90 & - & - & 90 \\ 44.4 & 50.4 & 25.2 & 27.6 & 25.2 & 27.6 & 21.1 & 19.5 & 21.1 & 19.5 & 16 & 14 & 11 & 9.4\end{array}$

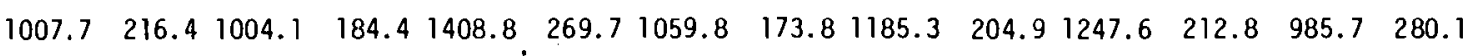
$\begin{array}{lllllll}1224.1 & 1188.5 & 1678.5 & 1233.6 & 1390.2 & 1460.4 & 1265.8\end{array}$ 


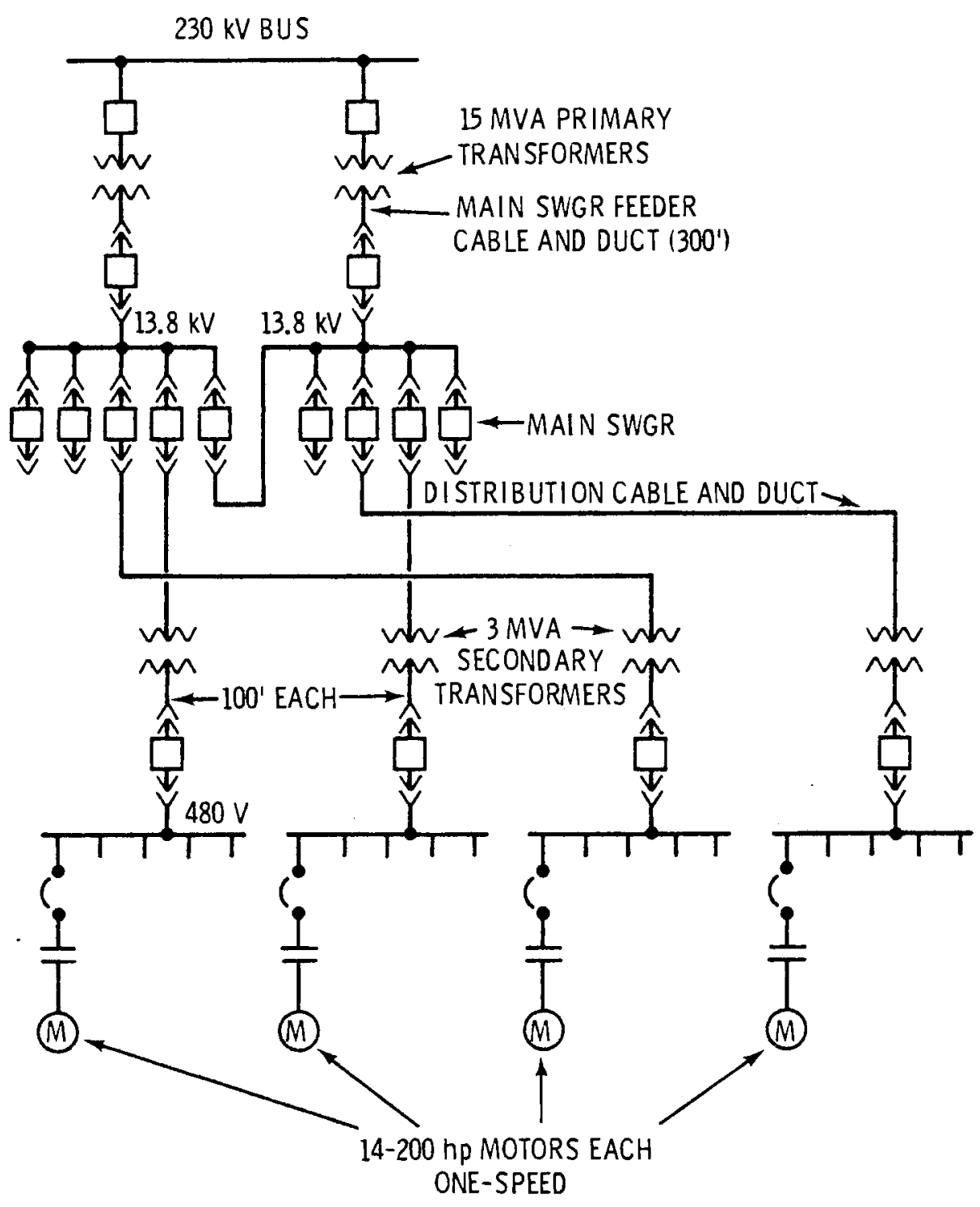

$11,200 \mathrm{hp} \mathrm{SYSTEM}$

FIGURE J-1. Electrical System Concept No. 3 Basic Diagram 


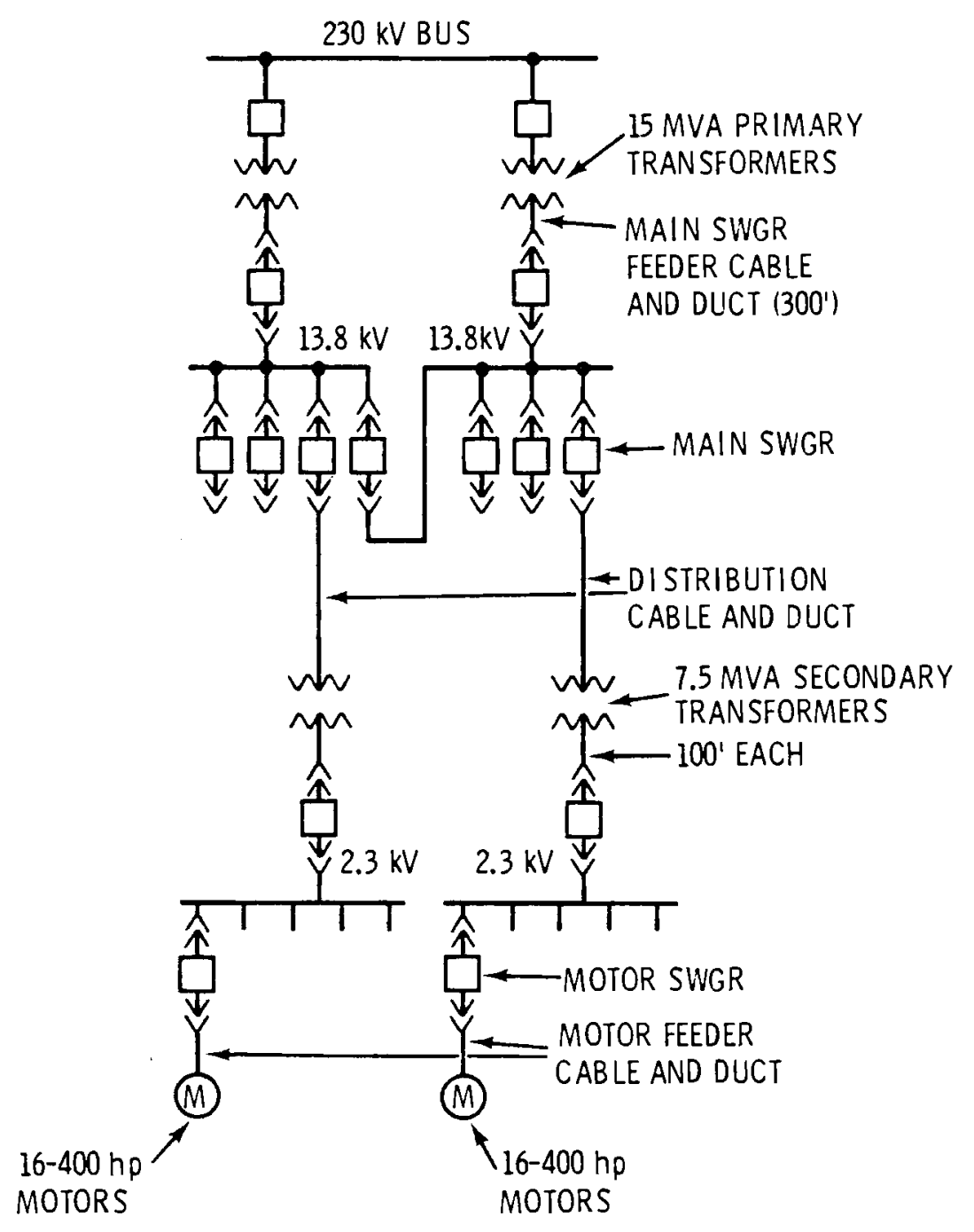

$19,200 \mathrm{hp} \mathrm{SYSTEM}$

FIGURE J-2. Electrical System Concept No. 4 Basic Diagram 


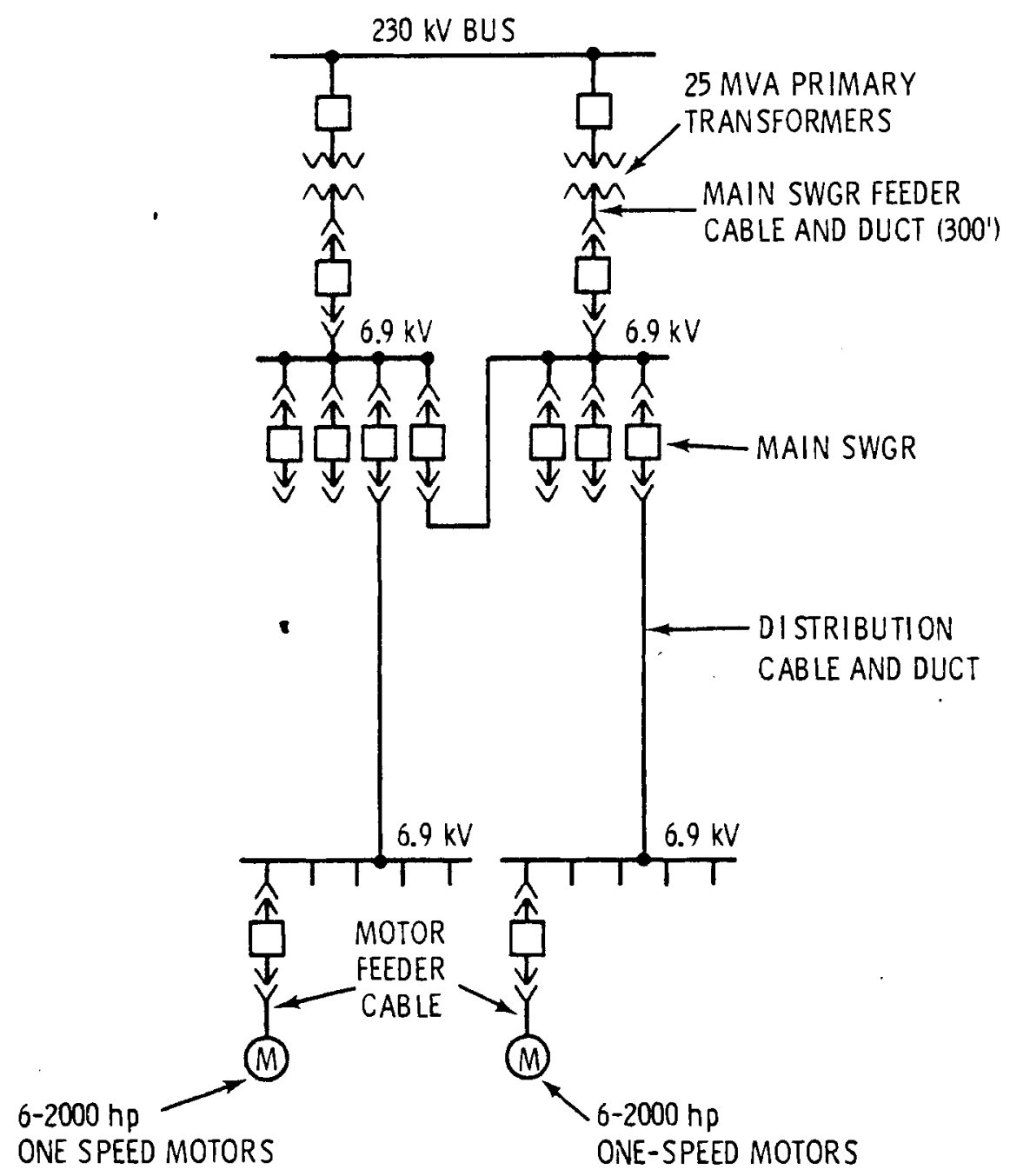

$24,000 \mathrm{hp} \mathrm{SYSTEM}$

FIGURE J-3. Electrical System Concept No. 7 Basic Diagram 


\section{APPENDIX REFERENCES}

1. A. B. Johnson, Jr., D. R. Pratt and G. E. Zima, A Survey of Materials and Corrosion Performance in Dry Cooling Applications. BNWL-1958, Battelle, Pacific Northwest Laboratories, Richland, WA, 99352 , March 1976.

2. E. G. Brush and W. L. Pearl, "Corrosion and Corrosion Product Release in Neutral Feedwater." Corrosion. 28: 129, 1972.

3. G. Resch, "Neue Richwerte füv Kesselspeise and Kesselwasser-Ein Beitrag Zur Neufassurg 1972." VGB Kraftwerkstechnik, Mitteilunger der VGB. 52(5): 385 , October $19 \overline{72 .}$

4. E. Beynon, Corrosion Inhibition on Automotive Cooling Systems. Union Carbide Corporation, Tarrytown, NY, 1968.

5. B. J. Kelly, Practical Corrosion Control of Closed Hot and Chilled Water Recirculating Systems. Nalco Reprint 134, Nalco Chemical Company, Chicago, IL.

6. H. L. Craig, Jr., and P. H. Woods, "Inhibition of Corrosion of the Hypereutectic Aluminum-Silicon Alloys in Antifreeze Solutions." Corrosion. 16: 129, 1960.

7. J. R. Myers and M. F. Obrecht, "Performance and Selection of Materials for Potable Hot Water Service." Mat. Prot. and Perf. 12: 17, 1973.

8. J. Draley and W. Ruther, "Aqueous Corrosion of Aluminum - Part 1 , Behavior of 1100 Alloy." Corrosion. 12: 441t, 1956.

9. H. H. Uhlig, Corrosion and Corrosion Control. Second edition, John Wiley and Sons, Inc., New York, NY, 1971.

10. Steam--Its Generation and Use. 38th Edition, Babcock and Wilcox, pp. 3-7, 1972 .

11. R. L. Horst, Jr., and R. T. Marchese, "Aluminum Surface Condenser Tubes for Steam Power Plants." ASME 62-WA-300, 1962.

12. D. R. Clements, "Aluminum Condenser Tubing for Electric Generating Facilities." ALCOS Memorandum, June 1969.

13. S. D. Reynolds and F. W. Pement, "Corrosion Failures in Power Plant Auxiliary Heat Exchangers." Mat1. Performance. 13: 21, 1974. 
14. B. J. Milleville, "The Case for Higher Velocities in Feedwater Piping." Proc. Am. Power Conf. 30: 475, 1968.

15. "Water Circulation Component and Installation Cost for the Dry Cooling Program." C-62264, Vitro Engineering, Richland, WA, January 1976.

16. "Ammonia Circulation System Component Costs, Dry Cooling Program." C-62283, Vitro Engineering, Richland, WA, June 1976. 


\section{DISTRIBUTION}

No. of

Copies

OFFSITE

A. A. Churm

Chicago Patent Group

Energy Research and

Development Administration

9800 South Cass Avenue

Argonne, IL 60439

Office of Assistant General

Counsel for Patents

Energy Research and

Development Administration

Washington, DC 20545

27 ERDA Technical Information Center

10 I. Helms

Advanced Concepts Evaluation Branch - F-309

ERDA Division of Nuclear Research and Application Washington, DC 20545

W. F. Savage

Chief, Advanced Concepts

Evaluation Branch

ERDA Division of Nuclear Research and Application Washington, DC 20545

D. C. Bauer

Director, Division of Nuclear Research and Application

Energy Research and

Development Administration

Washington, DC 20545

W. E. Mott

Director, Energy Control Technology

ERDA Division of Biomedical and

Environmental Research

Washington, DC 20545
No. of

Copies
B. R. Dickey

Allied Chemical Company

550 2nd Street

Idaho Falls, ID 83401

J. S. Joyce

Allis-Chalmers Power Systems, Inc.

1135 South 70th Street

West Allis, WI 53214

E. T. Wanderer

Aluminum Company of America

Alcoa Technical Center

Alcoa Center, OH 45069

H. J. Janzon

American Electric Power

2 Broadway

New York, NY 10004

T. Woods

Arizona Public Service Co.

2121 W. Cheryl Drive

Phoenix, AZ 85021

M. W. Peterson

Babcock \& Wilcox

Fossil Power Division

20 South Van Buren

Barberton, OH 44203

G. C. Creel

Baltimore Gas \& Electric Co. Gas \& Electric Building

Baltimore, MD 21203

E. Schinner

Baltimore Aircoil Co., Inc.

P.0. Box 7322

Baltimore, MD 21227 
No. of

Copies

J. P. Budliger

Battelle-Geneva

7 Route De Drizi

1227 Geneva, SWITZERLAND

P. Leung

Bechtel Corporation

P.0. Box 60860

Terminal Annex

Los Angeles, CA 90060

G. R. Retti

Bechtel Corporation

P.0. Box 3965

San Francisco, CA 94119

J. P. Rossie

R. W. Beck and Associates

400 Prudential Plaza

Denver, CO 80202

B. Westre

Black Hills Power and Light Company

P.0. Box 1400

Rapid City, SD 57701

L. E. Stamets

California State Energy

Resources Conservation and Development Commission

1111 Howe Avenue

Sacramento, CA 95825

J. Sel1

Carolina Power \& Light Co.

336 Fayettesville Street

Raleigh, NC 27602

J. Morse

Catalytic Construction Corp.

P.0. Box 11402

Charlotte, NC 28029
No. of

Copies

H. H. Osborn

Combustion Engineering

Air Preheater Company

Wellsville, NY 14895

R. H. Holyoak

Commonwealth Edison

One First Plaza

P.0. Box 767

Chicago, IL 60690

C. L. Newman

Consolidated Edison Co. of New York, Inc.

4 Irving Place

New York, NY 10003

W. A. Messner

Consolidated Edison Co. of New York, Inc.

4 Irving Place

New York, NY 10003

F. K. Moore

Cornell University

Ithaca, NY 14850

R. J. Haberski

Curtiss-Wright Corp.

One Passaic Street

Wood Ridge, NJ 07075

S. K. Blackley

Duke Power Company

P.0. Box 2178

Charlotte, NC 28201

E. Guyer

Dynatech Company

99 Erie Street

Cambridge, MA 02139 
No. of

Copies

J. K. Swindt

Ecodyne Cooling Products Co.

San Rosa, CA 95403

J. Maulbetsch

Electric Power Research

Institute

$3412 \mathrm{Hillview} \mathrm{Avenue}$

P.0. Box 10412

Palo Alto, CA 94304

L. Geller

Empire State Electric Energy

Research Corp.

1250 Broadway

New York, NY 10001

M. Maxwe11 (MD-61)

IERL-RTP

Environmental Protection Agency

Research Triangle Park, NC 27711

F. H. Rainwater

Environmental Protection Agency

Pacific Northwest Water

Laboratory

200 S.W. 35th Street

Corvallis, OR 97330

W. Hoydisch

Environmental Sciences and

Services

44-43 37th Street

Long Island City, NY 11101

E. L. Damon

Fostor Wheeler Energy Co.

110 S. Orange Avenue

Livingston, NJ 07039

A. M. Rubin

Frank 1 in Institute

Twentieth \& Parkway

Philadelphia, PA 19103
No. of

Copies

B. Davis

GEA Airexchangers, Inc.

46 Worthington Drive

Maryland Heights, MD 63043

A. C. Eutberg

General Atomic

P.0. Box 81608

San Diego, CA 92138

E. H. Miller

General Electric Co.

Large Steam Turbine Division

300 Nott Street

Schenectady, NY 12301

R. K. Shah

Harrison Radiator Division

General Motors Corp.

Lockport, NY 14094

J. F. Sebald

Gilbert Associates, Inc.

525 Lancaster Avenue

Reading, PA 19603

J. E. Taboric

Heat Transfer Research Inc.

1000 S. Fremont Avenue

Alhambre, CA 91802

E. C. Smith

Hudson Products

6855 Horwin Drive

Houston, TX 77036

M. W. Larinoff

Hudson Products

6855 Horwin Drive

Houston, TX 77036

W. R. Scott, Jr.

Ingersol1-Rand

Phillipsburg, NJ 08865 
No. of

Copies

C. Rocco

Italimpianti - Societa

Italiana Impianti p.a.

Piazza, Piccapietra 9

18121 Genoa, ITALY

J. L. Mulloy

Los Angeles Department of Water and Power

$111 \mathrm{~N}$. Hope Street

Los Angeles, CA 90012

R. J. Meyer

Louisiana Power \& Light Co.

142 Delaronde Street

New Orleans, LA 70174

E. S. Miliaras

The Charles T. Main Co.

Southeast Tower

Prudential Center

Boston, MA 02199

R. Landon

Marley Co.

5800 Fox Ridge Drive

Mission, KS 66202

L. R. Glicksman

Massachusetts Institute of Technology

77 Massachusetts Avenue

Cambridge, MA 02139

M. W. Golay

Massachusetts Institute of Technology

77 Massachusetts Avenue

Cambridge, MA 02139

R. Harleman

Department of Civil Engineering

Massachusetts Institute of Technology

77 Massachusetts Avenue

Cambridge, MA 02139
No. of

Copies

A. J. Vander Weyden

McDonnel Douglas Astronautics Co. 5301 Bols Avenue

Huntington Beach, CA 92647

R. Hofacher

Montana Power Co.

40 E. Broadway

Butte, MT 59701

W. G. Hoydysn

New York University

University Heights

New York, NY 10453

W. Kals

Niagara Blower

405 Lexington Avenue

New York, NY 10017

R. H. Meyer

Northeast Utilities

P.0. Box 270

Hartford, CT 06101

L. P. Davis

Department of Mechanical

Engineering

Oregon State University

Corvallis, OR 97330

C. E. Wicks

Department of Chemical

Engineering

Oregon State University

Corvallis, OR 97330

J. G. Knudson

Engineering Experiment

$$
\text { Station }
$$

Oregon State University

Corvallis, OR 97330

J. W. Michel

OTEC Heat Exchange Project

Activity

Oak Ridge National Laboratory

Box Y

Oak Ridge, TN 37830 
No. of Copies

A. A. Ariey

Pacific Gas \& Electric

77 Beale Street

San Francisco, CA 94106

F. F. Mautz

Pacific Gas \& Electric

77 Beale Street

San Francisco, CA 94106

P. G. Humphries

Pacific Power \& Light Co.

Public Service Bldg.

Portland, OR 97204

D. G. Pfeiffer

Pennsylvania Power \& Light

2 North Ninth Street

Allentown, PA 18101

T. Rozenmann

PFR Engineering Systems, Inc.

Suite 832

4676 Admiralty Way

Marina del Rey, CA 9029]

Prof. Ing. Carlo Roma

Piazza delle Muse 8

Rome, ITALY

G. L. Henderson

Power Generation Cooling Systems

4714 - 52nd Street S.

Seattle, WA 98118

R. F. Walker

Public Service of Colorado

5900 E. 39 th Avenue

Denver, CO 80207

J. D. Maddox

Public Service of New Mexico

Corporate Planning Dept.

Albuquerque, NM 87103
No. of

Copies

G. E. Collins

Research Cottrell

Hamon Cooling Tower Division

Box 750

Bound Brook, NJ 08805

R. Lindberg

Reynolds Aluminum $\mathrm{Co}$.

Reynolds Metallurgical

Research Laboratory

Richmond, VA 23261

R. G. Lacy

San Diego Gas \& Electric

101 Ash Street

San Diego, CA 92107

R. L. Skone

Seattle City Light

1015 Third Ave.

Seattle, WA 98104

F. A. McCracken

Southern California Edison

2244 Walnut Grove Avenue

Rosemead, CA 91770

P. Sporn

Consultant Engineer

74 Trinity P1., Suite 511

New York, NY 10006

A. L. London

Department of Mechanical

Engineering

Stanford University

Stanford, CA 94305

J. Y. Parce

Stearns and Rogers

$700 \mathrm{~S}$. Ash Street

Denver, CO 80222

D. H. Guild

Stone \& Webster Engineering Corp.

225 Franklin Street

Boston, MA 02107 
No. of

Copies

H. I. Wilson

Tampa Electric Co.

P.0. Box 111

Tampa, FL 33601

W. Keel

Texas Electric Service Co.

$115 \mathrm{~W}$. Seventh Street

Fort worth, TX 76102

A. A. Ward

Tucson Gas \& Electric 220 W. 6th Street

Tucson, AZ 85701

J. Bartz

Union Carbide Corp.

Linde Division

61 East Park Drive

Tonawanda, NY 14150

G. J. Kidd

Union Carbide Corp:

ORGDP - K-25

P.0. Box D

Oak Ridge, TN 37803

F. Notaro

Union Carbide Corp.

Linde Division

61 East Park Drive

Tonawanda, NY 14150

G. A. Englesson

United Engineers \&

Constructors

1401 Arch Street

Philadelphia, PA 19105

K. Simhan

University of Bremen

Bremen, WEST GERMANY

J. F. Kennedy

University of Iowa

Hydraulic Research Institute

Iowa City, IA 52240
No. of

Copies

J. H. Hutchinson

Utah Power \& Light

1407 W. N. Temple

Salt Lake City, UT 84103

S. Ragone

Virginia Electric \& Power Co.

700 E. Franklin Street

Richmond, VA 23261

J. T. Kimball

Washington State University

College of Engineering

Pullman, WA 99163

D. L. 01son

Washington Water Power Co.

E. 1411 Mission Avenue

Spokane, WA 99202

G. H. Soule

West Associates

Sierra Pacific Power Co.

100 E. Moana Lane

Reno, NV 89510

J. A. Barnett

Executive Director

Western States Water Council

220 South 2nd East

Suite 200

Salt Lake City, UT 84111

G. J. Silvestri

Westinghouse Electric Corp.

Steam Turbines Division

Lester Branch

Box 9175

Philadelphia, PA 19113

K. A. oleson

Westinghouse Electric Corp.

Steam Turbines Division

Lester Branch

Box 9175

Philadelphia, PA 19113 
No. of

Copies

L. E. Wilkinson

Consultant

6582 Ganon Street, S.E.

Salem, OR 97301

\section{ONSITE}

ERDA Richland Operations Office Energy Programs Division

H. E. Ransom

Westinghouse Hanford Company Hanford Engineering Development Laboratory

\section{J. Fletcher}

70 Battelle-Northwest

R. T. Allemann

P. A. Ard

D. J. Braun

D. J. Braun

J. W. Currie

D. E. Deonigi

R. L. Dillon

D. W. Dragnich

R. L. Drake

D. W. Faletti

J. W. Finnigan

B. C. Fryer

J. J. Hauth

A. J. Haverfield

C. H. Henager

A. B. Johnson

W. S. Kelly

R. S. Kemper

C. J. Knoll

W. V. Loscutoff

R. P. Marshall

D. E. Olesen

Y. Onishi

L. T. Pedersen

H. C. Riches

J. B. Schuette
No. of

Copies 


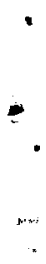

